\title{
Lessens Learned from Existing Biomass Power Plants
}

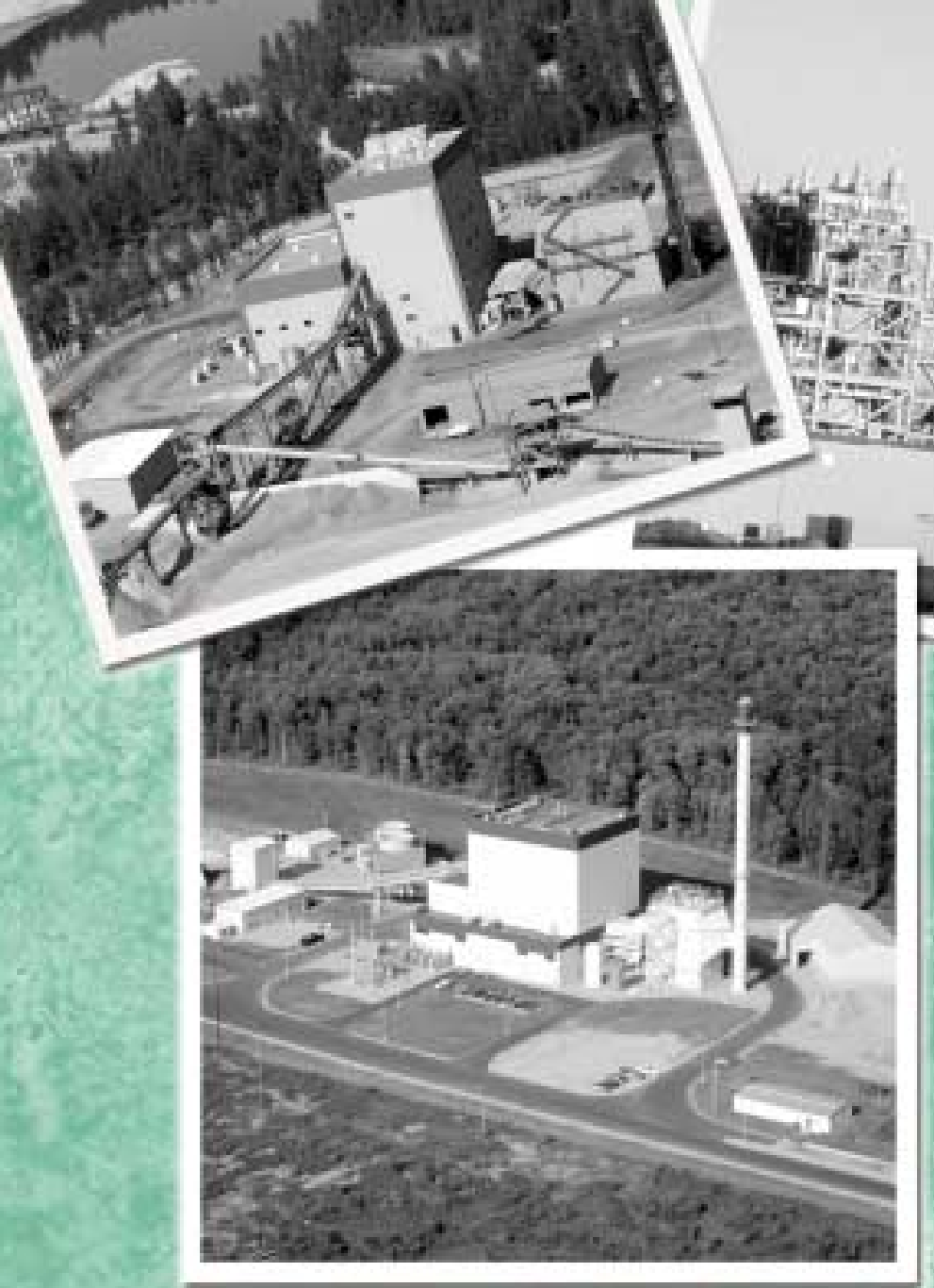


February 2000 • NREL/SR-570-26946

\section{Lessons Learned from Existing Biomass Power Plants}

G. Wiltsee

Appel Consultants, Inc.

Valencia, California

NREL Technical Monitor: Richard Bain

Prepared under Subcontract No. AXE-8-18008

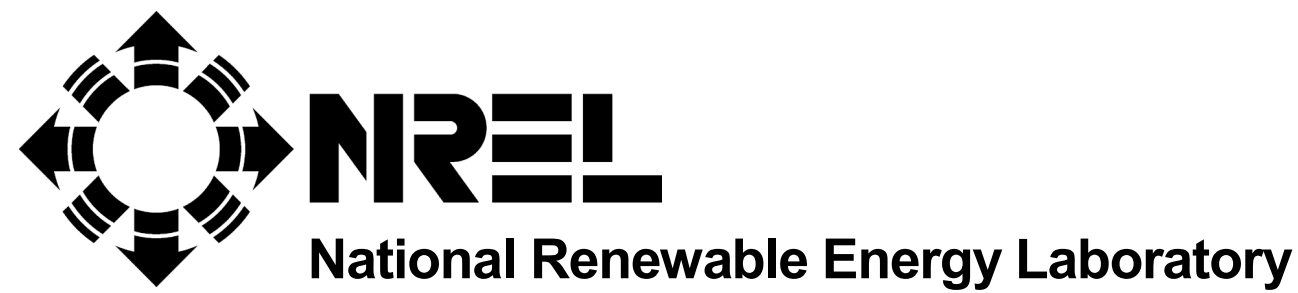

1617 Cole Boulevard

Golden, Colorado 80401-3393

NREL is a U.S. Department of Energy Laboratory

Operated by Midwest Research Institute $\bullet$ Battelle $\bullet$ Bechtel

Contract No. DE-AC36-99-G010337 


\section{NOTICE}

This report was prepared as an account of work sponsored by an agency of the United States government. Neither the United States government nor any agency thereof, nor any of their employees, makes any warranty, express or implied, or assumes any legal liability or responsibility for the accuracy, completeness, or usefulness of any information, apparatus, product, or process disclosed, or represents that its use would not infringe privately owned rights. Reference herein to any specific commercial product, process, or service by trade name, trademark, manufacturer, or otherwise does not necessarily constitute or imply its endorsement, recommendation, or favoring by the United States government or any agency thereof. The views and opinions of authors expressed herein do not necessarily state or reflect those of the United States government or any agency thereof.

Available electronically at http://www.doe.gov/bridge

Available for a processing fee to U.S. Department of Energy

and its contractors, in paper, from:

U.S. Department of Energy

Office of Scientific and Technical Information

P.O. Box 62

Oak Ridge, TN 37831-0062

phone: 865.576.8401

fax: 865.576.5728

email: reports@adonis.osti.gov

Available for sale to the public, in paper, from:

U.S. Department of Commerce

National Technical Information Service

5285 Port Royal Road

Springfield, VA 22161

phone: 800.553.6847

fax: 703.605.6900

email: orders@ntis.fedworld.gov

online ordering: http://www.ntis.gov/ordering.htm

Printed on paper containing at least $50 \%$ wastepaper, including $20 \%$ postconsumer waste 


\section{CONTENTS}

Section $\quad$ Page

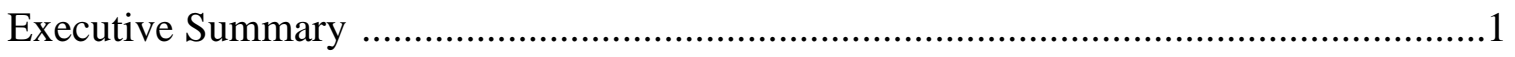

Bay Front Station, Ashland, Wisconsin .....................................................................10

Kettle Falls Station, Kettle Falls, Washington ..................................................................16

McNeil Generating Station, Burlington, Vermont ..........................................................23

Wheelabrator Shasta Plant, Anderson, California …………………………………......... 32

San Joaquin Valley Energy Partners, Chowchilla, El Nido, and Madera, California ........44

Boralex Stratton Energy, Stratton, Maine …………………………………………....56

Tracy Biomass Plant, Tracy, California ………………………………………........61

Tacoma Steam Plant No. 2, Tacoma, Washington ……………………………............66

Colmac Energy, Mecca, California ............................................................................

Grayling Generating Station, Grayling, Michigan ………………………………......8

Williams Lake Generating Station, British Columbia, Canada .........................................94

Multitrade Project, Hurt, Virginia ...............................................................................102

Ridge Generating Station, Auburndale, Florida …………………………...................107

Greenidge Station, Dresden, New York …………….............................................113

Camas Cogeneration Plant, Camas, Washington .........................................................119

Snohomish County PUD/Kimberly-Clark Corp., Everett, Washington ..........................125

Okeelanta Cogeneration Plant, South Bay, Florida ………………………………….....130

Lahti Gasification Cofiring Project, Lahti, Finland ........................................................137 


\section{EXECUTIVE SUMMARY}

This report includes summary information on 20 biomass power plants-18 in the United States, one in Canada, and one in Finland, which represent some of the leaders in the industry. Table 1 lists the 20 plants in order of on-line date, the same order in which they are presented in the report. In some cases, the on-line date means the date an older fossilfired plant started using biomass fuel commercially (not its original on-line date). Some of the information in the table is abbreviated, but can be clarified by referring to the specific plant sections.

Table 1

Summary of Biomass Power Plants in this Report

\begin{tabular}{|c|c|c|c|c|c|c|c|}
\hline Plant & Online & Fuels & Boiler(s) & $\mathrm{lb} / \mathrm{hr}$ & $\underline{\text { Psig }}$ & PF & IWe \\
\hline ont & 79 & Mill, TDF, coal & oal stokers & 280,000 & & & 30 \\
\hline alls & Dec-83 & Mill & st & 415,000 & 1500 & 950 & \\
\hline McNeil & Jun-84 & Forest, mill, urban & traveling grate stoker & 480,000 & 1275 & 950 & 50 \\
\hline Shasta & Dec-87 & Mill, forest, ag, & 3 traveling grate stokers & 510,000 & 900 & 905 & 49.9 \\
\hline El Nido (closed) & Oct- 88 & $\mathrm{Ag}$, forest, mill, & 1 bubbling FBC & 130,000 & 650 & 750 & 10 \\
\hline Madera (closed) & Jul-89 & $\mathrm{Ag}$, forest, mill, & 1 bubbling FBC & 260,000 & 850 & 850 & 2. \\
\hline & Nov-89 & Mill, forest & 1 traveling grate & 400,000 & 1485 & 955 & 4 \\
\hline Chowchilla II (closed) & Feb-90 & $\mathrm{Ag}$, forest, & $1 \mathrm{bub}$ & 130,000 & 650 & 750 & 10 \\
\hline Tracy & Dec-90 & & 1 wa & & & & 18.5 \\
\hline Tacoma (cofiring) & Aug-91 & Wood, RDF, coal & 2 bubbl & & 400 & 750 & 12 \\
\hline & Feb-92 & Urban, ag, coke & $2 \mathrm{CFH}$ & 464,000 & 1255 & 925 & 49 \\
\hline & & $\mathrm{M}$ & & & 1280 & 950 & 36.17 \\
\hline Lake & Ap & Mill & e & 50 & 1575 & 950 & 60 \\
\hline $\mathrm{Mu}$ & Jun-94 & Mill & & 726,000 & 1500 & 950 & 79.5 \\
\hline Ridge & Aug-94 & Urban & $1 \mathrm{t}$ & 345,000 & 1500 & 980 & 40 \\
\hline Greenidge ( & Oct-94 & Manufacturing & $\mathrm{PC}$ & 665,000 & 1465 & 1005 & $10.8^{*}$ \\
\hline & & & grate & & 600 & 750 & $38-48$ \\
\hline & & & & & 825 & 850 & 43 \\
\hline & & $\mathrm{B}$ & grate & $1,320,000$ & 1525 & 955 & 77 \\
\hline Lahti (cofiring, cogen) & Jan-98 & Urban, RDF & $1 \mathrm{CFB}$ gasifier $+\mathrm{PC}$ & 992,000 & 2500 & 1004 & $25^{* *}$ \\
\hline
\end{tabular}

*108 total net MW, $10 \%$ from wood and $90 \%$ from coal.

**167 total net MW, $15 \%$ from biofuels and $85 \%$ from coal.

The on-line dates of the plants span about 18 years, from December 1979 to January 1998. The types of biomass fuels used are abbreviated: "mill" refers to mill wastes, etc. Many boiler types are represented: six traveling grate stoker boilers, four water-cooled vibrating grate boilers, four bubbling fluidized bed combustors (FBCs), one circulating fluidized bed (CFB) boiler, one fixed-grate boiler, one sloping grate boiler, and two pulverized coal (PC) boilers retrofitted to cofire solid or gasified biomass. Steam temperatures for the biomass- 
fired boilers are $750^{\circ}-980^{\circ} \mathrm{F}$; for the PC boilers, $1004^{\circ}-1005^{\circ} \mathrm{F}$. The nominal sizes of the plants range from $10 \mathrm{MW}$ to $79.5 \mathrm{MW}$.

\section{Electricity Generation and Fuel Consumption}

Table 2 lists the plants in order of electricity generation, in gigawatt-hours/yr (GWh/yr). For some plants, the generation numbers are actual statistics from a recent year (1996, 1997, or 1998). For plants that did not provide these statistics, the generation rates were estimated based on available information. The same is true for the annual $\mathrm{CFs}(\mathrm{CF}, \%)$ and net plant heat rates $(\mathrm{Btu} / \mathrm{kWh})$. The biomass fuel consumptions were calculated by multiplying $\mathrm{GWh} / \mathrm{yr}$ times Btu/kWh, and dividing by 8.5 million Btu/t $(4250 \mathrm{Btu} / \mathrm{lb}$, or $8500 \mathrm{Btu} /$ dry lb with $50 \%$ moisture content).

Table 2

Plant Electricity Generation and Biomass Fuel Consumption Estimates

\begin{tabular}{|c|c|c|c|c|c|c|}
\hline Plant & Location & MWe & GWh/yr & CF, \% & Btu/kWh & Tons/yr* \\
\hline Williams Lake & British Columbia & 60.0 & 558 & 106 & 11,700 & 768,000 \\
\hline Okeelanta (cogen) & Florida & 74.0 & 454 & 70 & 13,000 & 694,000 \\
\hline Shasta & California & 49.9 & 418 & 96 & 17,200 & 846,000 \\
\hline Colmac & California & 49.0 & 393 & 90 & 12,400 & 573,000 \\
\hline Stratton & Maine & 45.0 & 353 & 90 & 13,500 & 561,000 \\
\hline Kettle Falls & W ashington & 46.0 & 327 & 82 & 14,100 & 542,000 \\
\hline Snohomish (cogen) & W ashington & 39.0 & 205 & 60 & 17,000 & 410,000 \\
\hline Ridge & Florida & 40.0 & 200 & 57 & 16,000 & 376,000 \\
\hline Grayling & Michigan & 36.0 & 200 & 63 & 13,600 & 320,000 \\
\hline Bay Front & Wisconsin & 30.0 & 164 & 62 & 000 & 251,000 \\
\hline McNeil & Vermont & 50.0 & 155 & 35 & 14,000 & 255,000 \\
\hline Lahti (cogen) & Finland & 25.0 & 153 & 70 & 14,000 & 252,000 \\
\hline Multitrade & Virginia & 79.5 & 133 & 19 & 14,000 & 219,000 \\
\hline Madera & California & 25.0 & 131 & 60 & 20,000 & 308,000 \\
\hline Tracy & California & 18.5 & 130 & 80 & 14,000 & 214,000 \\
\hline Camas (cogen) & W ashington & 17.0 & 97 & 65 & 17,000 & 194,000 \\
\hline Tacoma & W ashington & 40.0 & 94 & 27 & 20,000 & 221,000 \\
\hline Greenidge & New York & 10.8 & 76 & 80 & 11,000 & 98,000 \\
\hline Chowchilla II & California & 10.0 & 53 & 60 & 20,000 & 125,000 \\
\hline El Nido & California & 10.0 & 53 & 60 & 20,000 & 125,000 \\
\hline
\end{tabular}

*Tons/year are calculated, assuming $4250 \mathrm{Btu} / \mathrm{lb}$. 


\section{Capacity Factors}

Annual CFs range from $19 \%$ to $106 \%$. Some plants with low CFs (e.g., Multitrade and McNeil) are peaking units. The plants with very high CFs have special circumstances. Shasta and Colmac were still under the first 10 years of California Standard Offer contracts when the data were obtained. Williams Lake can operate as high as $15 \%$ over its rated capacity, and can frequently sell extra power.

\section{Heat Rates}

The Williams Lake plant also holds the distinction of having the largest single boiler $(60 \mathrm{MW})$ and the lowest heat rate $(11,700 \mathrm{Btu} / \mathrm{kWh})$ of any $100 \%$ biomass-fired power plant. Biomass-cofired coal plants can achieve slightly lower heat rates, as exemplified by Greenidge Station $(11,000 \mathrm{Btu} / \mathrm{kWh}$ on the biomass portion of the fuel, compared to 9818 on coal alone). The least efficient plants in this report have heat rates of about 20,000 Btu/kWh. A "typical" value is about 14,000 Btu/kWh (24.4\% thermal efficiency, HHV).

\section{Cogeneration}

The four cogeneration plants in the report-Okeelanta, Snohomish, Lahti, and Camas - are recent plants, using the latest technology, in traditional niches for biomass power: two at pulp and paper mills (Snohomish and Camas), one at a sugar mill (Okeelanta), and one at a municipal district heating plant (Lahti). The estimates given in Table 2 for these plants represent only the solid fuel biomass portion of the energy input. At the two pulp and paper mills, recovery boilers produce large fractions of the total steam from waste liquor; the wood waste boilers at these facilities constitute focus of this report. At Lahti, coal and natural gas produce most of the energy; wood wastes and refuse derived fuel (RDF) are fed to a gasifier that supplies low-Btu gas to the boiler. The Okeelanta cogeneration plant burns bagasse for about 6 months of the year, and burns urban and other wood wastes at other times.

\section{Fuels}

The cost of biomass fuel from mill wastes and urban wood wastes can range from about $\$ 0 /$ MBtu to about $\$ 1.40 / \mathrm{MBtu}$, depending on the distance from the fuel source to the power plant. Getting to zero fuel cost depends on locating a power plant in an urban area next to a wood waste processor, or next to a large sawmill or group of sawmills. Deregulation will make this zero fuel cost strategy more important in the future.

Agricultural residues (primarily orchard tree removals) can be processed into fuel and delivered to nearby biomass power plants for about \$1/MBtu. Only if open burning of residues is prohibited will transferring some of this cost to the orchard owners be possible.

Forest residues are much more costly $(\$ 2.40-\$ 3.50 / \mathrm{MBtu})$, because of the high costs of gathering the material in remote and difficult terrain, processing it to fuel, and transporting it to power plants. There are strong arguments for government programs to bear the costs of forest management and (in the West) fire prevention. Only if such programs are created will forest residues be as cost-competitive fuel as in the future.

Plants that have come close to zero fuel cost are Williams Lake, which is located very close to five large sawmills, and Ridge, which accepts raw urban wood wastes and whole tires, and burns landfill gas. Other plants burning primarily mill wastes include Shasta, Kettle Falls, Stratton, Snohomish, Grayling, Bay Front, Multitrade, and Camas. Other plants 
burning primarily urban wood wastes (and in some cases RDF) are Okeelanta, Colmac, Lahti, and Tacoma. Sawdust from furniture manufacturing is the main biomass fuel at the Greenidge plant. Plants burning agricultural residues include Okeelanta, Tracy, Madera, Chowchilla II, and El Nido. Plants burning significant amounts of forest residues include McNeil, Shasta, Stratton, and Grayling.

\section{Lessons Learned}

The project experiences described in the following sections capture some important lessons learned that lead in the direction of an improved biomass power industry. Undoubtedly, many other problems and solutions did not surface in the interviews and in the documents and articles that served as source materials. A summary of the lessons learned from these 20 biomass plants follows; in each category an effort is made to identify plants that illustrate particular points, so the reader can go to those sections to learn more.

Fuel

The highest priority at most biomass power plants is to obtain the lowest-cost fuels possible. This involves tradeoffs in fuel quality, affects the design and operation of the system, and frequently is limited by permit requirements. Some fuel-related lessons illustrated in this report are:

- At Bay Front, the conversion from coal and oil to biomass and other waste fuels kept an old generating station operating and provided continued employment.

- At the McNeil Station, long-term fuel contracts insisted on by financing institutions created some costly problems. As required, McNeil had 15 or 20 long- term fuel contracts when it started up. The CF dropped because of dispatch requirements, resulting in lawsuits and settlements with fuel suppliers and odors from the wood piles. The plant now runs more economically by buying wood fuel under shortterm contracts.

- Maintaining adequate fuel supply in the midst of a declining regional timber industry has been the single biggest challenge for the Shasta plant. Almost from startup, Shasta has tried to diversify its fuel sources. From an initial list of permitted fuels that included only mill waste, logging/thinning residue, and cull logs, Shasta added agricultural residues, fiber farm residues, land and road clearing wood wastes, tree trimmings and yard wastes, and natural gas.

- The San Joaquin Valley Energy Partners plants (Chowchilla II, El Nido, and Madera) experimented in combusting low-cost, low-demand agricultural waste materials such as grape pomace, green waste, onion and garlic skins, and bedding materials not desired by competing facilities. However, the most difficult-to-burn agricultural residues were assigned to the "tertiary" fuel category and mixed in small percentages with better fuels, primarily wood.

- Experience at the Tracy plant shows that urban wood waste can be a comparatively inexpensive fuel $(\sim \$ 0.35 / \mathrm{MBtu})$ if the plant is located close to the urban area. Compared to urban wood waste, orchard wood is relatively expensive $(\sim \$ 1.00 / \mathrm{MBtu})$ because growers are used to simply pushing and burning it, and are generally not willing to pay a fee to have the wood removed.

- Tacoma found that focusing on fuel cost $(\phi / \mathrm{kWh})$ rather than fuels that provide highest efficiency (Btu/kWh) saved the plant $\$ 600,000 / y$ r. Opportunity fuels (with tipping fees) can eliminate fuel costs and generate net revenues. Fuel procurement should be one of the highest priorities and a full-time job. 
- At the Williams Lake plant, with uncertainty in the forestry industry, unknown impacts of Asian market upheaval, high provincial stumpage fees, and closure of some coastal sawmills and pulp mills, the biggest threat to an enviable operating record appears to be fuel availability.

- The Ridge Generating Station is an urban waste recycling facility, working within the local waste management infrastructure to provide a low-cost recycling service to waste generators, and to obtain a free or negative-cost fuel mix (urban wood wastes, scrap tires, and landfill gas) for energy production.

- The Snohomish Cogeneration plant design anticipated the trend toward declining quantities of sawmill residues, and the increasing use of urban wood wastes in the region. Siting the plant at a paper mill provided an excellent fit for steam use, as well as expertise in wood waste handling and combustion.

Fuel Yard and Fuel Feed System

The area of a biomass power plant that can almost be counted on to be mentioned in response to the question "Have you had any significant problems or lessons learned?" is the fuel yard and fuel feed system. Most plants in this report spent significant time and money during the first year or two of operation, solving problems such as fuel pile odors and heating, excessive equipment wear, fuel hangups and bottlenecks in the feed system, tramp metal separation problems, wide fluctuations in fuel moisture to the boiler, etc., or making changes in the fuel yard to respond to market opportunities. Examples noted in this report include:

- At Bay Front Northern States Power (NSP) engineers installed and improved (over time) a system that allows feeding of $100 \%$ biomass, $100 \%$ coal, or any combination of the two. Because wood fuel quality varies more than coal quality, proper tuning of the automatic combustion controls is more important when firing wood. Operators must pay close attention and periodically adjust feeders.

- With the addition of a debarker, high-speed V-drum chipper, chip screen, and overhead bins, the Shasta plant was able to offer to custom chip logs, keeping the $35 \%$ of the log not suitable for chips. In times of low chip prices, Shasta still purchases the whole log. Shasta successfully marketed the program to some of the largest landowners in California.

- At Shasta, the operators learned to blend all the fuels into a homogeneous mixture that allowed the boilers to fire at a consistent rate and maintain maximum load under all conditions, without violating environmental standards, excessively corroding heat transfer surfaces, or slagging beyond the point where the boilers required cleaning more than twice per year.

- At Stratton, the original owners spent about \$1.8 million during the first year of operation to improve the operation of the fuel yard.

- Tacoma personnel stress the need to take extra care at the beginning of the project with design of the fuel feed system. Selecting a proven fuel feed system is important.

- The only area of the Williams Lake plant that was modified after startup was the fuel handling system. Minor modifications were made to improve performance, such as adding the ability to reverse the dragchains on the dumper hoppers, to make it easier to unplug fuel jams; and adding three more rolls to each disk screen (12 rolls were provided originally), to reduce the carryover of fine particles that tended to plug up the hog. 
- The Multitrade plant's minor problems included fuel feeding problems in the early days of operation (quickly corrected); erosion and corrosion in the fuel splitter boxes and conveyor belt shrouds (corrected by relining with plastic); and occasional heating and odor problems in the fuel pile until they learned not to let any part of the pile age more than 1 year.

- The Greenidge Station found that the technology for preparing biomass fuel for cofiring in a PC boiler needs further economic evaluation, research, and development. Grinders do not normally produce a product that has good flow characteristics. The wood fibers are sticky, stringy, and elongated when produced from a grinding operation. The fuel product needs to processed by equipment that produces a chip.

Design for Fuel Flexibility

Many biomass plants change fuels significantly over the years, as opportunities arise or old fuel sources dry up. These changes are often not predictable. The best strategy to deal with this problem is to have a plant design and permits that allow as much fuel flexibility as possible. For example:

- Bay Front was a coal-fired stoker plant that converted to wood firing and cofiring capability in 1979. Experience showed that ash fouling and slagging problems were much more severe when cofiring wood and coal than when firing either fuel alone. NSP now operates in either $100 \%$ coal or $100 \%$ wood firing mode.

- In 1989, the ability to burn natural gas was added to McNeil Station. Summer pricing for Canadian gas was more attractive than wood prices at that time. Six fossil fuel burners were installed, allowing full load capability $(50 \mathrm{MW})$ on gas and 15 MW capability on No. 2 oil. Gas prices rose during the mid-1990s, and McNeil burned almost no natural gas from 1997 to 1998.

- At the Shasta plant, a large hammermill was added to the fuel processing system to allow the use of a broader range of fuels. This reduced fuel costs by allowing the plant to process opportunity fuels such as railroad ties, brush, and prunings.

- The Tacoma plant was constrained by a limited fuel supply and permit, and worked hard to develop more options to use opportunity fuels (tipping fee fuels, some of which are not biomass) — waste oil, asphalt shingles, petroleum coke, etc.

- Colmac found that modifying its permit to allow the use of petroleum coke was worthwhile. At times, waste fossil fuels can be more economical than biomass.

- The Ridge fuel yard can handle essentially any type or size of wood waste; its only restriction is that it will not accept palm trees. The simple and reliable traveling grate stoker boiler can burn these mixed wood wastes, including yard wastes, and can burn crude tire-derived fuel (TDF) and landfill gas. The emission control system with a lime spray dryer and baghouse can remove almost any significant pollutant encountered in these wastes.

Location

As realtors say, "Location, location, location!" Biomass residues and wastes are local fuels, with very low energy densities compared to fossil fuels. Transport costs become very significant after about $20 \mathrm{mil}$, and usually prohibitive beyond 100 or $200 \mathrm{mil}$. The ability to have the waste generators deliver the fuel to the plant site at their own expense requires a location very close to the sources of waste. There are also other considerations, such as the proximity to residential neighborhoods. For example: 
- The primary lesson learned from the McNeil plant experience in Burlington, Vermont, is careful attention to the siting of a biomass-fueled plant. Siting the plant in a residential neighborhood of a small city has caused a number of problems and extra expenses over the years: a permit requirement to use trains for fuel supply, high taxes, high labor rates, local political involvement, and neighborhood complaints about odors and noise.

- The Colmac plant shows that urban wood waste can be a comparatively expensive fuel $(\sim 1.50 / \mathrm{MBtu})$ if the plant is located far outside the urban area. The transportation cost is significant. An urban biomass plant can derive income from its fuel with a location and tipping fees that attract wood waste generators with loads to dump.

Reliability and Dependability

Several plant managers with the best long-term operating records stressed the necessity for placing a high value on reliability and dependability. This is true during plant design and equipment selection, and during operation. For example:

- Outside of planned outages, the Kettle Falls plant has an availability factor of about $98 \%$ over a continuous 16-year period. The superintendent has high praise for the people on the staff. The plant is always exceptionally clean and neat.

- The Shasta general manager advises: "Always place a high value on reliability and dependability, for these will allow you to be considered a 'player' and thus a participant in the development of special programs with the utility."

- At Williams Lake, which has an outstanding performance record, the chief engineer stressed that staying on top of maintenance programs at all times is essential.

\section{Partnerships}

The most successful projects have developed formal or informal partnerships with their key customers and suppliers. The relationship with the utility company that buys the power is usually the most important. This may change as generators simply bid their power into a power pool. Cogeneration plants by definition must have close relationships with their steam users. Sometimes there are a few large fuel suppliers (such as sawmills) with whom special relationships are crucial. Examples in this report that illustrate the importance of strong partnerships include:

- In the words of the Shasta general manager: "But these new approaches must go forward on a very different basis than our past biomass developments. They must go forward in partnership with utilities. While the utility may want to participate in such systems, they will not and cannot do so unless the cost to ratepayers is very close to that of other generating options."

- Like several other biomass power plants, the Grayling Station is operated as a cycling plant. It has run at about a $70 \%-80 \% \mathrm{CF}$ during peak demand periods, and at about a $40 \%-50 \%$ CF during off-peak periods. The McNeil, Multitrade, and Ridge plants are other examples of cycling plants.

- The arrangement between the Camas Mill and its electric utility (PacifiCorp) is mutually beneficial. The utility-financed turbine/generator provides the mill with an additional source of cash flow, without significantly changing the mill's steam generation and delivery system. The utility has added about $50 \mathrm{MW}$ of reliable generating capacity to its system for a relatively small investment, and has strengthened its relationship with a major customer. 
- The Okeelanta Cogeneration Plant provides many environmental benefits, and should serve as a reliable energy source for the sugar mill and the electric utility. Unfortunately, the owners and the utility could not amicably resolve their differences over a "standard offer" contract. The ensuing lawsuits, bankruptcy, shutdown, and layoffs significantly affected the project.

\section{Cofiring}

Once the availability of low-cost biomass fuel is established, the primary issue addressed in most retrofitted cofiring projects is how to feed the fuel (and in what form to feed it) to the coal-fired boiler. There are of course many other issues, such as effects on boiler operations, plant capacity, emissions, and ash quality. Some of these are highlighted by lessons learned at four plants in this report:

- Bay Front could use standard wood sizing and feeding equipment because its coalfired boilers were stokers. Cofiring was possible at any ratio of wood to coal from $0 \%$ to $100 \%$. However, slagging and fouling was very severe because of the interaction between the alkali in the wood and the sulfur in the coal.

- The bubbling FBCs at Tacoma can fire 0\%-100\% wood, 0\%-50\% coal, and 0\%-50\% RDF (permit limitation). The actual fuel mix on a heat input basis from 1993 to 1997 was 54\%-68\% waste wood, $12 \%-32 \%$ coal, and 12\%-20\% RDF. Opportunity fuels that command a tipping fee or can be obtained free became a high priority in 1997.

- The cofiring experience at Greenidge Station demonstrates that a separate fuel feed system can effectively feed wood wastes to a PC unit. The economics at this site are favorable; the difference between coal and wood prices is $\$ 0.45-\$ 0.79 / \mathrm{MBtu}$. The plant has continued to cofire wood and invest in system improvements since the testing began more than 4 years ago.

- The Lahti cofiring project at a PC- and natural gas-fired district heating and electric generation plant in Finland uses a CFB gasifier to convert wood wastes and RDF to low-Btu gas that is burned in the boiler. The operation has been technically successful for 1 year, and gives utilities in the United States another option to consider when examining the feasibility of cofiring biomass and waste fuels in coal-fired boilers.

\section{Benefits}

The 20 biomass projects in this report provide many concrete illustrations of environmental and economic benefits. The Kettle Falls, Williams Lake, and Multitrade plants provide air quality benefits in rural settings where sawmills used to pollute the air with teepee burners. The Ridge, Tacoma, and Lahti plants serve urban areas by burning urban waste fuels cleanly; Lahti provides district heat as well. The Okeelanta, Tracy, and San Joaquin plants burn agricultural residues cleanly, which formerly were burned with no emission controls. The Shasta, McNeil, and Grayling plants serve the forest management operations in their areas by cleanly burning unmerchantable wood, brush, and limbs. For example:

- The Bay Front plant was being considered for phaseout as larger, more efficient units came on line in the NSP system. Adding the ability to use biomass fuel kept the plant operating, saved jobs, and improved waste management.

- Long-term residents in the Kettle Falls area reported major reductions in haze after the plant went into operation. The plant improved air quality by eliminating numerous wigwam burners formerly used to dispose of mill wastes. 
- In the forests near the Shasta plant: "The result is a healthier, faster growing forest that has a dramatically lowered potential to be destroyed by fire. There are now adequate moisture, nutrients and sunlight for the remaining trees and net growth often triples. The remaining trees regain their traditional resistance to insect and disease attack."

- The Grayling and Ridge projects were planned and the plants were designed with waste management roles in mind-one in a rural setting and the other in an urban setting. Efforts were made to fit constructively into the local economic and environmental landscapes, with clearly positive results.

\section{Subsidy Programs Do Not Last}

As a final note, the Shasta general manager's list of lessons learned includes this one: "Beware of entering a regulatory system in which the utility commission or legislature has determined that it is acceptable for ratepayers to pay the full cost of your technology. Such things do not last." 


\section{BAY FRONT STATION, ASHLAND, WISCONSIN}

Northern States Power Company's Bay Front Station, located in Ashland, Wisconsin, on Lake Superior, can generate as much as $75 \mathrm{MW}$ of electricity using coal, wood, shredded rubber, and natural gas. Units 1 and 2 account for $40 \mathrm{MW}$ of this nominal capacity. Units 1 and 2 have spreader stoker boilers that were converted from coal only to a multiple fuel coal/wood/shredded rubber capability in 1979. Either boilers can be fired entirely on wood, coal, or any blend of wood and coal. However, the preferred mode of operation is to fire $100 \%$ coal during periods of high load (44 MW total output), and 100\% wood during other times (30 MW total output). During 1998 Bay Front Units 1 and 2 consumed about $220,000 \mathrm{t}$ of wood wastes from mills, about 30,000 t of shredded railroad ties, and about 2,000 t of shredded tires. Of the 292,200 MWh generated by Units 1 and 2 during the first 11 months of 1998, about 164,000 MWh (56\%) were generated from wood.

\section{Vital Statistics}

\begin{tabular}{lcc}
\hline Configuration & 2 modified coal stoker boilers \\
\hline Operating mode (fuel) & Wood + TDF & Coal \\
Plant output, MW & 30 & 44 \\
MWh/yr, 1998 & 164,000 & 128,000 \\
\hline Fuel consumed, tons/year: & & \\
Wood wastes (from mills) & 220,000 \\
Railroad ties (shredded) & 30,000 \\
Scrap tires (shredded) & 2,000 \\
\hline
\end{tabular}

\section{History and Outlook}

Units 1 and 2 at Bay Front were originally designed to fire $100 \%$ coal. These B\&W stoker grate boilers (rated approximately $200,000 \mathrm{lb} / \mathrm{h}$ ) were converted to crude oil firing without coal capability during the early 1970s. During late 1970s the oil burners were removed, and stokers were reinstalled for burning various grades of coal. At this time provisions were added to allow waste wood products to be blended with the coal. Subsequent modifications enabled either boiler to be fired entirely on wood, coal, or blends of wood, coal, and shredded rubber.

During 1991 the Bay Front Station used 171,000 t of waste wood in Units 1 and 2. Twelve years after the plant first began burning wood, it remained the lowest-cost fuel by nearly a factor of two. From 1980 to 1994 , nearly 1.8 million t of wood waste were burned at the plant. 
Efforts to cofire wood and coal in these boilers were abandoned in the late 1990s because of ash fouling and slagging problems caused by the interactions of the fuel and ash properties of the two fuels. The coal used at the plant is an Eastern bituminous coal with an acidic ash. Buildups of slag on the furnace walls hindered operations when the coal and wood were cofired. The preferred mode of operation now is $100 \%$ coal or $100 \%$ wood (and a small percentage of shredded tires). The plant is now evaluating a gas topping technology developed by Gas Research Institute (GRI), which would cofire wood and natural gas. If successful, the use of gas topping could make coal firing obsolete in Units 1 and 2.

\section{Plant Flowsheet and Design Information}

\section{Bay Front Station, Units 1 and 2}

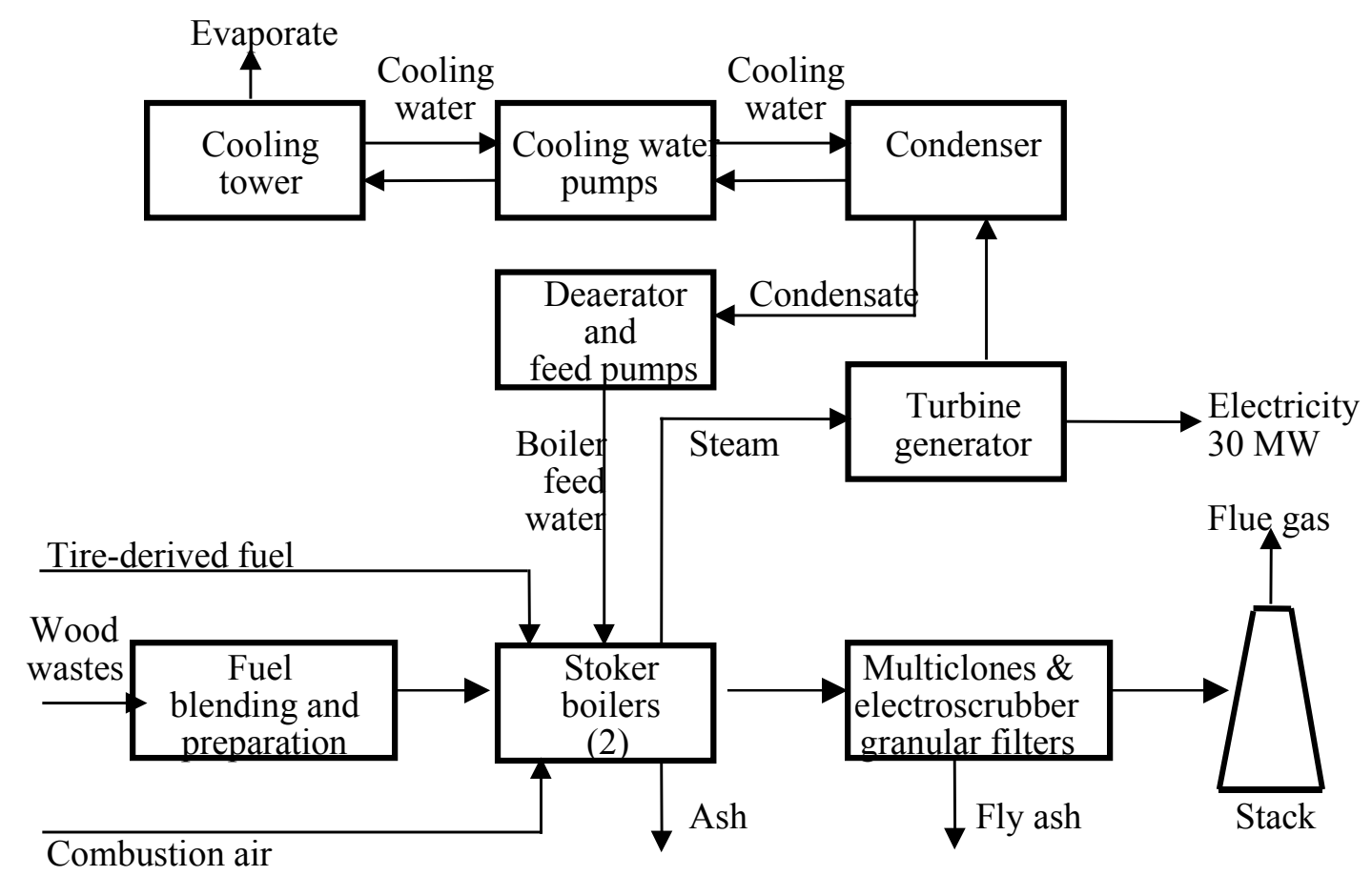

Fuel System

All the wood the plant receives is currently delivered by trucks, which are weighed entering and leaving. Bottom-dumped wood is either stockpiled or immediately reclaimed with a large front-end loader with an oversized bucket. Trailers are dumped into a live bottom receiving hopper that conveys the wood waste on an inclined belt conveyor to a rotating disk screen. A $10-\mathrm{ft}$ permanent magnet is located at the discharge end of the receiving hopper to collect tramp iron and steel. Oversized material from the disk screen passes into a 600-hp, 1200-rpm hammerhog for further size reduction. The waste wood fuel is then conveyed to the top of a 450 -ton storage bin, where a distribution conveyor evenly distributes the waste wood fuel. 
Bay Front does not use any type of dust suppression/collection system to control wood dust. Weather covers over the conveyors and enclosures around the hog and similar equipment help keep the dust in and rain and snow out. On very windy days, dust from the wood pile can be a nuisance. Green wood dust does not pose as great a threat of explosion as does fugitive coal dust.

The 450-ton wood bin is rectangular, with a flat bottom and an aspect ratio of 1.8 to 1 (lower than the recommended maximum of 3 to 1 ). Numerous areas throughout the wood handling system are monitored by the boiler control room operator via closed-circuit television. This system very effectively reduces equipment damage and labor costs. All enclosed chutes are protected with sonic sensors that automatically shut down the equipment feeding the transfer point in the event of overloading or plugging.

As fuel is required by the boilers, a discharge auger removes a cross section of the stored wood from the bottom of the storage bin and dumps the well-mixed fuel product onto a conveyor belt. The belt transfers the fuel for both boilers to a diversion gate where the fuel is proportioned as needed to four metering bins, two for each boiler. These act as surge bins between the fuel handling and combustion systems, and provide accurate and redundant metering of fuel to the boiler. Fuel is fed from the metering bins to rotary air locks by variable speed augers located at the bottom of the bins.

The rotary air locks feed the material into an 8-inch diameter blow line that is fed by a highpressure blower. The fuel is then pneumatically transported into the plant and to the front of the boiler, where the high-velocity fuel flow terminates in a target box. The waste wood is then gravity fed from the target box to a swinging spout fuel proportioner which serves three of the boiler's six combination wood/coal feeders. Because of the abrasive nature of the fuel, all elbows and transition pieces in the fuel blow line are equipped with replaceable wear plates.

Currently air used to transport the fuel is injected into the boiler along with the fuel. Evaluation of possible efficiency and combustion improvements dictates that the elimination of this cold transport air from use in the combustion system be given further consideration.

\section{Boilers}

When NSP studied the feasibility of waste wood combustion at the Bay Front Station, considerable attention was given to the evaluation of furnace volume requirements. The boilers had enough grate area and furnace volume to satisfactorily burn wood fuel. When burning $100 \%$ wood, however, the Bay Front boilers cannot reach the original rated boiler capacity of $200,000 \mathrm{lb} / \mathrm{h}$; only $140,000 \mathrm{lb} / \mathrm{h}$.

\section{Fuels}

During 1991 the Bay Front Plant used 171,000 t of waste wood in Units 1 and 2. The waste wood comes mainly from sawmills located within a 65-mile radius; one mill is 115 miles from the plant. Most of the wood consists of bark and sawdust from various types of pine, aspen, hemlock, and spruce. As-received heating value and moisture content of the wood vary considerably depending on the supplier, but overall during 1991 averaged $5000 \mathrm{Btu} / \mathrm{lb}$ and $43 \%$, respectively. The overall ash content averaged less than $2 \%$, and sulfur averaged $0.02 \%$. 
In 1998 the plant had contracts for 200,000-225,000 t/yr of wood wastes, mostly mill wastes. A Louisiana Pacific mill had a contract for 120,000-130,000 t/yr; the next largest contract was for about 30,000 t/yr; about 12 additional mills supplied the remaining 50,000 t/year. The use of shredded railroad ties as fuel was increasing in 1998, to more than $30,000 \mathrm{t} / \mathrm{yr}$. The estimated maximum capacity to burn shredded ties is $60,000 \mathrm{t} / \mathrm{yr}$. This is a "higher Btu" fuel compared to the 35\%-55\% moisture content mill residues. Tire chips (about $2000 \mathrm{t} / \mathrm{yr}$ ) are even higher in heating value, at about 12,000 Btu/lb.

Because of its light weight, sawdust is handled better when mixed with bark. A 50/50 blend is preferred for handling and firing. Green mill waste quality usually falls within the following ranges: Btu/lb 4000-6000, moisture 35\%-55\%, ash 1\%-5\%, and sulfur $0.01 \%$ $0.1 \%$. Other, drier wood wastes can yield heat contents of 6500-7500 Btu/lb. Shredded railroad ties average $6500 \mathrm{Btu} / \mathrm{lb}$; shredded pallets average $7000 \mathrm{Btu} / \mathrm{lb}$; and some flooring and other dried manufactured products wastes are approximately $7500 \mathrm{Btu} / \mathrm{lb}$. Most of the ash in mill waste is contained in the bark. Logs harvested in wet conditions contain more dirt. Mishandling by loader operators when retrieving wood from stockpiles can also add dirt to the fuel.

\section{Operating Experience}

The wood fuel feed rate for a given heat input is about twice that of coal on a weight basis, and more than four times that of coal on a volume basis. Wood fuel quality varies more than coal quality. Proper tuning of the automatic combustion controls is more important when firing wood. Operators must pay close attention, and periodically adjust feeders to maintain even fuel distribution, adjust the ratio of overfire to underfire air, etc.

Combustion gas temperatures in the upper furnace area in the Bay Front units typically average $1700^{\circ}-1900^{\circ} \mathrm{F}$ when burning $100 \%$ wood. In the case of $100 \%$ coal, the temperatures are typically a few hundred degrees higher. Wood combustion requires more excess air and more overfire air than coal combustion.

Coal is usually worse than wood for slagging and fouling. However, a combination of wood and coal firing often produces worse slagging and fouling conditions than coal firing alone. This is because of the combination of alkali in the wood and sulfur in the coal. For these reasons, Bay Front no longer cofires wood and coal.

Wood contains less ash than coal, but ash can be more difficult to collect because of its physical and electrical properties. Bottom ash, and fly ash from various mechanical collectors, are removed via a pneumatic system that conveys the ash to a separator/baghouse on top of the plant's ash silo. There has been one fire in the pneumatic system's baghouse; other than this the plant has experienced very few problems with this system.

Fly ash reinjection from a primary collector helps improve boiler efficiency when operating on wood, but may also introduce more fine particles into the flue gas stream, potentially increasing emissions. 


\section{Environmental Performance}

Wood is inherently low in sulfur content, so sulfur dioxidet $\left(\mathrm{SO}_{2}\right)$ emissions are not of concern. Another advantage of wood combustion compared to coal or oil combustion is a reduced level of nitrogen oxidet $\left(\mathrm{NO}_{\mathrm{x}}\right)$ formation and discharge. The fuel-bound nitrogen in wood is typically $10 \%$ that in coal, and the lower combustion temperature reduces fixation of air-bound nitrogen. Carbon monoxide (CO) emissions from wood burning typically exceed those from coal burning, and can be minimized by using preheated combustion air, preparing good fuel, and carefully controlling excess and overfire air.

Particulate emissions are controlled by electrified gravel bed filters. NSP chose this technology because of concerns about poor performance with precipitators and fires with baghouses. One disadvantage of this technology is a high pressure drop through the filter media. The addition of gravel bed filters along with higher excess air requirements created the need for larger induced draft (ID) fans.

Bay Front Station has a common ash system for all its boilers (except for bottom ash from the one cyclone boiler, which fires coal only). The combination coal/wood ash is trucked to a licensed solid waste disposal site. No unique problems have been encountered in handling and disposing of the ash.

\section{Economic Information}

The main advantage of waste fuel combustion at the Bay Front Station is fuel cost savings. Oil prices during the mid to late 1970s dictated that the Bay Front plant, then owned by Lake Superior District Power Company, find alternative, lower-cost, fuel options. Using wood residue as a boiler fuel made productive use of a material that was previously disposed in a landfill. Use of waste wood helps stimulate the local economy by keeping fuel dollars in Wisconsin Waste wood is Bay Front's lowest-cost fuel option by nearly a factor of two.

Specific fuel cost information for the Bay Front Station is confidential. In 1994, NSP stated in a conference paper that "the weighted average delivered cost for wood fuel in the entire NSP system is expected to be less than $\$ 0.75$ per million Btu."

\section{Lessons Learned}

The Bay Front Station has benefited from its conversion from coal and oil to biomass and other waste fuels. The reduction in fuel costs has helped keep this old generating station operating and has provided continued employment.

Although the fuel handling and feeding systems allow for operation on $100 \%$ wood, $100 \%$ coal, and any combination of the two fuels, experience with these stoker boilers has shown that ash fouling and slagging problems are too severe when cofiring wood and coal. NSP now operates in either $100 \%$ coal or $100 \%$ wood firing mode. 


\section{Sources and Contacts}

The information in this section is based primarily on two conference papers that were presented by NSP personnel:

- Biomass Combustion Conference, Reno, Nevada, January 26-28, 1992. “A Comparison of Wood, Coal, and RDF Combustion Systems-Focus on NSP Bay Front and French Island," by Kenneth Langr.

- BIOENERGY '94, Sixth National Bioenergy Conference, Reno/Sparks, Nevada, October 2-6, 1994. "Biomass Utilization at Northern States Power Company," by Richard P. Ellis.

Additional information was provided by Joe Brobjorg of NSP's fuel resources department, in phone conversations during December 1998.

Joe Brobjorg

Fuel Resources Department

Northern States Power Company

414 Nicollet Mall

Minneapolis, MN 55401

Phone: 612-330-2856 Fax: 612-330-7671

joseph.brobjorg@nspco.com 


\section{KETTLE FALLS STATION, KETTLE FALLS, WASHINGTON}

Avista Corporation, previously known as the Washington Water Power Company (WWP), has operated a 46- $\mathrm{MW}_{\mathrm{e}}$ (net) wood-fired steam turbine power plant at Kettle Falls, Washington, since 1983. Avista is an investor-owned utility company located in Spokane, Washington. The plant site is 86 miles north of Spokane next to the Columbia River. Fuel consists primarily of lumber mill wastes from mills in northeastern Washington, and some in Canada.

Vital Statistics

\begin{tabular}{lcccc}
\hline $\begin{array}{l}\text { Design capacity, net MWe } \\
\text { Configuration }\end{array}$ & \multicolumn{4}{c}{46} \\
Fuels & \multicolumn{4}{c}{ Traveling grate stoker boiler } \\
Wood wastes (mill residues)
\end{tabular}

\section{History and Outlook}

With new hydroelectric resources nearly exhausted in the Inland Northwest, WWP began searching for affordable alternative energy sources during the late 1970s. Numerous lumber mills scattered throughout the Pacific Northwest were coming under increasing scrutiny for the visual and atmospheric pollution caused by their wigwam burners.

Feasibility, site selection, and preliminary design studies were completed during 1978 and 1979. Based on favorable results of these studies, the company began the licensing phase of the project, which included preparing a preliminary plant design to support the development of a budget, obtaining licenses to construct, and securing fuel supplies for the plant. This effort was finished in January 1980, but the project was put on hold for a year because of economic conditions. Detailed engineering and procurement of equipment began in February 1981, and site construction commenced in June 1981. Construction of the Kettle Falls Generating Station went smoothly, finishing ahead of schedule. The facility began commercial service in December 1983. With the plant's opening, WWP became the first utility in the nation to operate a stand-alone power plant of this size fired entirely by wood waste. 


\section{Licensing}

In November 1979, applications for 22 permits were submitted to state and federal agencies. The state issued a draft environmental impact statement in December 1979 and the final environmental impact statement in March 1980. All state permits were then approved.

An application for a Prevention of Significant Deterioration construction permit was filed with the U.S. Environmental Protection Agency (EPA) in July 1979. The application was judged to be complete in December 1979 and a Preliminary Determination was issued in May 1980. The final permit was issued in July 1980. For a project of this size burning waste wood the major air quality concern is emission of particulate matter (PM). The EPA determined that an electrostatic precipitator (ESP) with an outlet grain loading of 0.02 grains per dry standard cubic foot ( $\mathrm{gr} / \mathrm{dscf}$ ) at $12 \% \mathrm{CO}_{2}$ represented Best Available Control Technology. To meet this requirement, a precipitator capable of $99.46 \%$ collection efficiency was specified.

The licensing phase of the project, which included preliminary engineering to support the licensing process, required an expenditure of $\$ 1,420,000$ over an 18 -mo period.

\section{Plant Flowsheet and Design Information}

\section{Kettle Falls Generating Station}

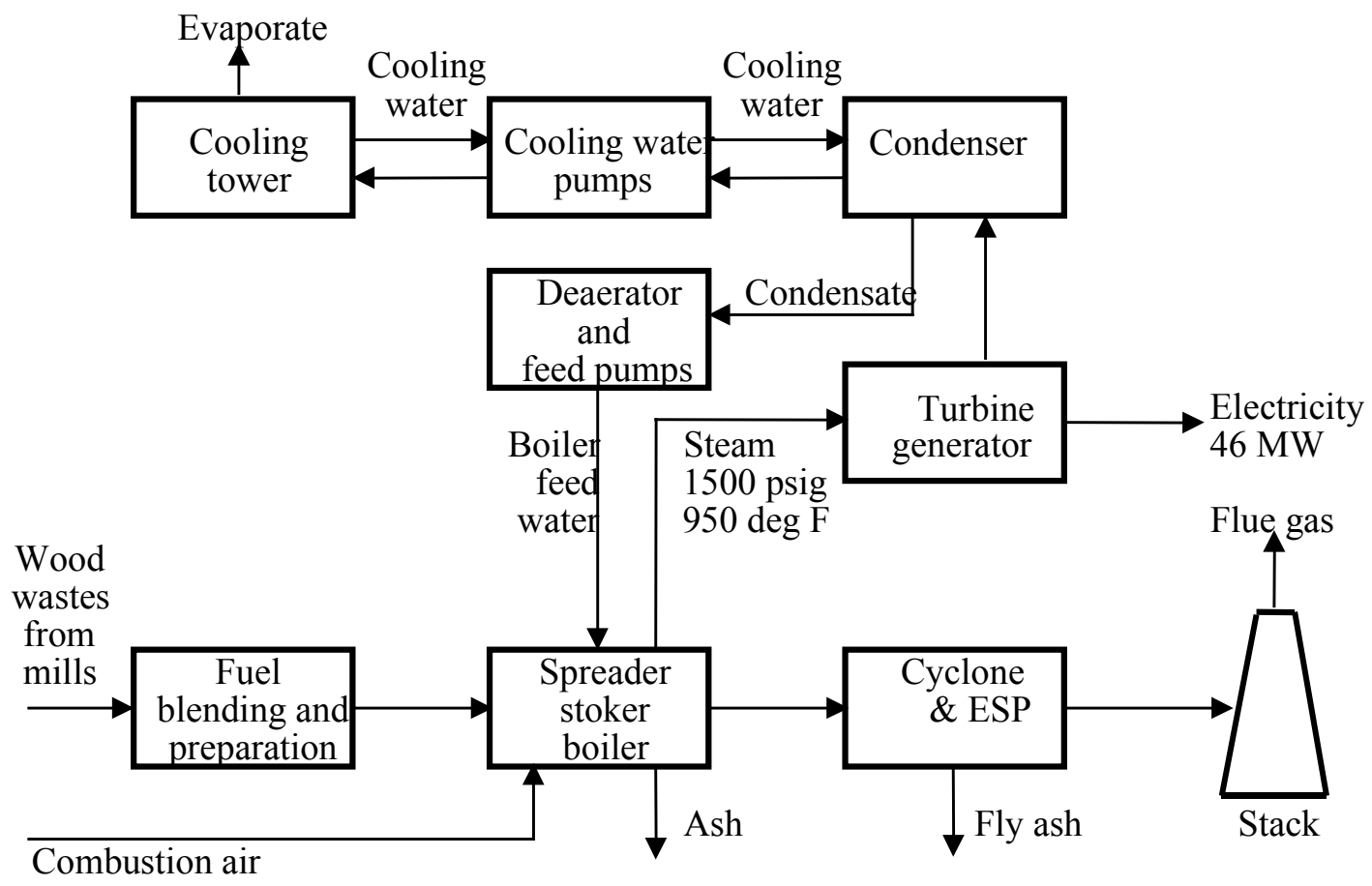


Fuel System

The wood fuel handling system is designed to minimize transfer points and storage bins because of the strong tendencies of wood waste to "bridge" and "rat-hole." The wood handling system was furnished by Lamb-Grays Harbor. Wood waste is delivered to two truck dumpers at the plant. The wood waste is conveyed from the truck dumpers to a disk screen (designed to reject oversized material) to a hammerhog. The disk screen is designed so wood waste as large as $3 \mathrm{in}$. is directed to a conveyor belt for transfer to the stackout system. A self-cleaning magnet and metal detector are included upstream of the disk screen to remove tramp iron.

Two stackout systems are provided: a tripper conveyor to distribute fuel on the pile for long-term storage, and a rotating boom that distributes fuel onto the live storage pile. A bulldozer is used to help distribute the fuel on the storage pile and to reclaim fuel. Wood waste is stored in an outdoor pile with a capacity equivalent to a 60-d fuel supply.

The fuel is reclaimed on a first-in, first-out basis to minimize problems associated with spontaneous combustion. The primary method of reclaiming fuel is a top-of-the-pile conveyor that rotates in a semicircle about the stacker tower structure. An under-pile dragchain is included for backup when maintenance is being performed on the primary system.

The reclaimed wood waste is transported via a belt conveyor to a second disk screen, the purpose of which is to remove frozen chunks of wood waste during the winter or oversized pieces that have not been initially screened. The rejects are dumped into a storage bin for manual recycle to the hammerhog. The wood waste is then conveyed to the powerhouse after passing under a magnet further remove tramp iron.

In the powerhouse, the wood fuel is distributed to six fuel feeder bins using a dragchain To avoid problems of bridging and rat-holing associated with large bunkers, the feeder bins have limited storage capacity. The input conveyor system is specified for a capacity of $10 \%$ more than the maximum expected fuel flow rate to avoid starving any fuel feeder bins. Excess fuel is returned to the wood storage pile via a belt conveyor. Fuel is removed from the bottom of the fuel bins by screw feeders, which direct it to pneumatic distributors, which in turn feed it to the traveling grate located at the bottom of the boiler.

\section{Boiler}

The traveling grate spreader stoker boiler was furnished by Combustion Engineering and has the following specifications: Type VU-40, subcritical, natural circulation, wood-wastefired, balance-draft boiler with furnace volume of 42,649 $\mathrm{ft}^{3}$ and rated 415,000 lb/h (MCR) steam flow at $1500 \mathrm{psig}$ and $950^{\circ} \mathrm{F}$ superheater outlet temperature. No external dryers are provided; the wood waste dries in the boiler combustion section. The steam generator is a balanced draft unit with forced draft (FD) and ID fans. Natural gas is the backup fuel and is used for ignition and for flame stability at loads lower than about $70 \%$ of maximum. The boiler is enclosed in a building to provide weather protection and to facilitate maintenance during the winter. 
The boiler has upper and lower drums with water wall tubes in the furnace section. In the convection section are a two-stage superheater, an economizer, and a tubular air heater. Design feedwater temperature to the boiler is $463^{\circ} \mathrm{F}$. Main steam temperature is controlled by attemperator sprays between the superheater stages. Steam soot blowers are used to clean the boiler heat transfer surfaces. The design efficiency of the boiler is $70 \%$.

\section{Turbine/Generator}

Steam from the boiler is expanded through a General Electric (GE) 17-stage, single flow, condensing turbine to produce mechanical energy for driving a direct coupled alternating current generator. The turbine is specified for design inlet steam conditions of $1450 \mathrm{psig}$ and $950^{\circ} \mathrm{F}$ with a design exhaust pressure of 2.5 -in. $\mathrm{Hg}$ abs. The turbine nameplate rating is $46 \mathrm{MW}$ while extracting steam for five stages of feedwater heating.

The turbine cycle uses five stages of regenerative feedwater heating, including four closed heat exchangers plus a deaerator. Two $100 \%$ capacity boiler feed pumps are provided. The primary pump is electrically driven, and a steam turbine-driven pump is maintained in a rolling standby condition to serve as an emergency backup for boiler superheat protection. This is necessary because of the large fuel inventory on the boiler grate. The two BinghamWillamette full-capacity, high-pressure boiler feed pumps are rated $985 \mathrm{gpm}$ at $1950 \mathrm{ft}$ TDH. The single-flow centrifugal pumps feature 11 stages. The main boiler feedwater pump is driven by a 1500-hp electric motor. An auxiliary pump is driven by a 1470 Terry turbine designed to operate on 900 psig steam supplied from the main steam header.

The GE generator is a 13.8-kV, 3600-rpm, three-phase, hydrogen-intercooled, synchronous machine, and rated at $53,400 \mathrm{kVA}$ at 0.95 power factor, with a 0.58 shortcircuit ratio. Excitation is provided by a GE solid-state, power-potential transformer/ power-current transformer, thyrister-controlled, self-excitation system. A step-up transformer is included in the plant to transmit power to the grid at $115 \mathrm{kV}$.

Turbine exhaust steam is condensed in a shell-and-tube surface condenser furnished by Transamerica DeLaval. The condenser has a carbon steel shell and stainless steel tubes. A two-cell evaporative, mechanical draft, counterflow cooling tower, furnished by Research Cottrell, is used to reject plant heat. A counterflow tower was selected instead of the more economical cross-flow tower to provide additional freeze protection for cold weather operation. The power plant makeup water source is the domestic water supply from the City of Kettle Falls, Washington.

\section{Ash Removal}

The ash removal system consists of a combination of dragchain and screw conveyors that collect ash from the boiler grate, siftings hopper, air heater, mechanical collector, and precipitator. Bottom ash is discharged from the traveling grate to a water-filled bottom ash hopper. Bottom ash is continuously removed from the bottom ash hopper by a submerged chain conveyor system. Fly ash from the economizer hopper, air heater hopper, cyclone collectors, and ESP hoppers is removed in a dry condition with dragchain conveyors and mixed with the wet bottom ash for transfer to portable containers. The ash is then trucked to a nearby landfill for disposal. 


\section{Emissions Control}

The particulate removal system, an ESP furnished by Flakt, Inc., is designed to limit emissions to a maximum of $0.02 \mathrm{gr} / \mathrm{sdcf}$. Large particles and char are removed by cyclone collectors at the exit of the air heater. Smaller particles are removed in an ESP. Because the char can ignite in an oxygen-rich environment, the ESP is positioned at the discharge of the ID fan to ensure a positive pressure and prevent air leakage into the precipitator. The clean flue gas leaving the ESP is dispersed through a 180-ft high stack.

The Flakt Inc. ESP has $122,723 \mathrm{ft}^{2}$ of collecting surface area, four fields, and maximum power consumption of $190 \mathrm{~kW}$. It limits emissions to $0.020 \mathrm{gr} / \mathrm{sdcf}$. The single $180-\mathrm{ft}$ tall corten-steel stack, $10 \mathrm{ft}$ in diameter, has test ports and opacity meters located about halfway up. (The original ESP had 99,456 $\mathrm{ft}^{2}$ of collecting surface area, and was replaced during the plant's first year of operation, as discussed under Operating Experience.)

\section{Plant Control}

The integrated, coordinated Bailey Controls Network 90 system operator interface consists of three, eight-color interactive graphic CRT/keyboard terminals, two printers, and selected electronic manual-automatic selector stations. The turbine is equipped with a GE Mark III digital electro-hydraulic control system.

\section{Fuels}

The Kettle Falls plant is designed to burn approximately 500,000 t/yr of 50\% moisture wood waste. Fuel consists of bark, sawdust, shavings, and slabs-milling by-products from about $15 \log$ processing plants in northeast Washington, southeast British Columbia, and northern Idaho-approximately a 100-mi radius. The economic haul distance is longer in cases where backhauls are possible. The average fuel higher heating value (HHV) is about $4,700 \mathrm{Btu} / \mathrm{lb}$ as received. The average one-way haul from suppliers under contract is about $46 \mathrm{mi}$. Average transportation costs were estimated in 1983 at $10.8 \notin / \mathrm{t}-\mathrm{mi}$. Average delivered fuel costs were estimated in 1983 to be about $\$ 12 /$ green $t$ (approximately $\$ 1.40 / \mathrm{MBtu})$.

The supply of hog fuel generated by the lumber mills in the Kettle Falls area continues to be more than adequate. The plant has had to curtail fuel deliveries from major suppliers at times. The mills in Canada are generating more biomass fuel than ever, as environmental restrictions on wigwam burning are tightened.

\section{Operating Experience}

The plant has consistently run very well throughout its history, with no major problems after the initial operating year. During the first year of operation, problems were experienced with the ESP. The ESP box was undersized, which caused too much fly ash to be collected on the fourth field plate. When the plate was rapped to discharge the fly ash to the hopper, some of the fly ash was emitted from the stack. The ESP manufacturer paid for a replacement unit, which was sized with much greater volume. The new ESP, supplied by Flakt, can meet the permit specifications with only two of its four fields operating. 
From the start of commercial operation in 1983 through the early 1990s, the station's CF averaged $88.9 \%$, which includes 6 months the plant was off line for precipitator replacement shortly after opening. The $\mathrm{CF}$ has been lower in recent years, not because of problems at the plant, but because of the very low market prices for hydroelectric energy in the Pacific Northwest. Production statistics for 1994-1998 are as follows:

\begin{tabular}{|c|c|c|c|c|c|}
\hline & 1994 & 1995 & 1996 & 1997 & 1998 \\
\hline Net generation, million $\mathrm{kWh}$ & 329.8 & 200.2 & 284.2 & 279.9 & 326.5 \\
\hline Annual CF, $\%$ & 81.9 & 49.7 & 70.5 & 69.5 & 81.1 \\
\hline Annual service factor, $\%$ & 82.3 & 56.5 & 82.0 & & \\
\hline
\end{tabular}

During 1997 and 1998 some equipment items were replaced because of wear or corrosion. These included the superheat section in the boiler, and some tubes or tube sections in the air heater.

Originally rated at $42.5 \mathrm{MW}$ (net), the Kettle Falls plant can operate continuously at $46 \mathrm{MW}$ (net). On average, the plant generates $1000 \mathrm{kWh}$ of electricity for every $1.5 \mathrm{t}$ of sawmill waste burned. This is equivalent to a net plant heat rate of about $14,100 \mathrm{Btu} / \mathrm{kWh}$ ( $24.2 \%$ thermal efficiency, HHV basis).

\section{Environmental Performance}

No mention was made of any difficulties in complying with the plant's environmental permit requirements after the ESP was replaced during the first year of operation. The stack opacity is generally $1.2 \%-1.5 \%$.

\section{Economic Information}

In 1983 dollars, the estimated capital cost at completion of the project was $\$ 82.5$ million. This is about $\$ 1940 / \mathrm{kW}$ in 1983 dollars, or about $\$ 3100 / \mathrm{kW}$ in 1998 dollars using the GDP deflator index. This figure includes all capitalized items including electrical transmission required to integrate the output into the system. The costs of financing are not included in this figure.

\section{Lessons Learned}

Using wood waste as a renewable resource for power generation has proven to be a successful operation for Avista Corporation and a sound environmental solution for the wood products industry. Long-term residents in the Kettle Falls area reported major reductions in haze after the plant went into operation. The plant improved air quality by eliminating numerous wigwam burners in Stevens County.

In terms of operating performance, the Kettle Falls plant has an exemplary record. Outside of planned outages, the plant has an availability factor of about $98 \%$ over a continuous 16year period. The plant superintendent has high praise for the people on the staff. The plant is always exceptionally clean and neat. 
Interestingly, the Williams Lake plant, which started up 10 years after the Kettle Falls plant, directly benefited from the lessons learned from successful operation at Kettle Falls. WWP was a $49 \%$ owner in the Williams Lake project, and passed the Kettle Falls plant's solutions along during design and early operation of Williams Lake. WWP's share in the project was subsequently bought out. Williams Lake, which is documented elsewhere in this report, is the largest and most efficient biomass power plant currently operating.

\section{Sources and Contacts}

Most of the information in this section was obtained from plant brochures and Power Magazine articles (January 1983 issue and 1984 Generation Planbook). Updates on operating experience were obtained from George Perks, former plant superintendent, in June 1984 and February 1997. The most recent update on the plant's operating experience was given by the current plant superintendent, Dean Hull, in January 1999.

Dean Hull

Plant Superintendent

Kettle Falls Generating Station

Avista Corporation

P.O. Box 3727

Spokane, WA 99220

Phone: 509-738-2449

Fax: 509-738-2598 


\section{MCNEIL GENERATING STATION, BURLINGTON, VERMONT}

The Joseph C. McNeil Generating Station of the Burlington Electric Department (BED), located in Burlington, Vermont, has a nominal capacity of $50 \mathrm{MW}_{\mathrm{e}}$ and has operated since 1984. This plant is the largest U.S. utility-owned plant burning wood. When built, it was the largest dedicated wood-fired electric generating station in the world. Plant operation has been successful, although New England Power Pool (NEPOOL) economic dispatch procedures have limited the operations. The plant was retrofitted in 1989 to burn natural gas, either alone or in combination with wood. The plant has cycled and switched fuels, as demanded by fuel prices, fuel availability, and NEPOOL's requirements. It has had to start up as often as 210 times annually. Between 1990 and 1994, about two-thirds of the fuel requirements were supplied by wood and one-third by gas. In 1995, about $7 \%$ of the energy input was from natural gas, and in 1996 through 1998 virtually all the fuel burned was wood, except for the use of gas during startup. During 1997 and 1998 the plant ran at a CF of about $35 \%$.

Vital Statistics

\begin{tabular}{|c|c|c|c|}
\hline $\begin{array}{l}\text { Design capacity, net MWe } \\
\text { Configuration }\end{array}$ & \multicolumn{3}{|c|}{$\begin{array}{c}50 \\
\text { Traveling grate stoker boiler }\end{array}$} \\
\hline Fuels & $\begin{array}{l}\text { Wood wastes: } \\
\text { Natural gas (when }\end{array}$ & $\begin{array}{l}\text { Forest re } \\
\text { Mill resi } \\
\text { Urban re } \\
\text { economic }\end{array}$ & $\begin{array}{l}\text { idues } \\
\text { lues } \\
\text { sidues } \\
\text { al) }\end{array}$ \\
\hline $\begin{array}{l}\text { Year } \\
\text { Net generation, MWh/yr } \\
\text { Annual CF, \% }\end{array}$ & $\begin{array}{cc}1995 & 1996 \\
136,000 & 137,000 \\
31.0 & 31.1 \\
\end{array}$ & $\begin{array}{c}1997 \\
155,000 \\
35.4 \\
\end{array}$ & $\begin{array}{c}1998 * \\
155,000 \\
35.4 \\
\end{array}$ \\
\hline $\begin{array}{l}\text { Net heat rate, Btu/kWh } \\
\text { Thermal efficiency, HHV, \% }\end{array}$ & $\begin{array}{r}13,71 \\
24.2 \\
\end{array}$ & $\begin{array}{l}14,125 \\
-24.9 \\
\end{array}$ & \\
\hline
\end{tabular}

*Projected in December 1998.

\section{History}

During the 1970s, most of the power supply for Burlington came from the Moran Generating Station, which consisted of three 1950s-vintage, 10-MW stoker coal-fired units. Electric load growth, the aging of the Moran station, and outdated emission controls prompted BED to examine ways to provide additional generating capacity to meet the city's needs. Studies were conducted, and wood fuel scored high on all counts: locally 
available, reliable, cost-effective, nonpolluting, and acceptable to the public. Using wood fuel as a generation source could produce important benefits: putting money back into the Vermont economy, improving the condition of the state's forests, and providing jobs for Vermonters.

The pulp and paper industry had proven for years that bark and wood chips could be burned efficiently and with good environmental controls. The real unknown was the availability of a fuel delivery network that could reliably supply wood fuel at a reasonable price. In 1977, Unit 1 at Moran Station was modified for wood chip cofiring. Based on the success with Unit 1, a second unit was converted to wood in 1979. In 1983 the Moran plant used more than $100,000 \mathrm{t}$ of wood chips for fuel in addition to 30,670 tons of coal, 146 million $\mathrm{ft}^{3}$ of natural gas, and 121,011 gal of No. 2 fuel oil. Economic and technical studies verified that expanded wood firing was viable.

A bond issue was passed by the voters of the City of Burlington in 1978 to finance the construction of the McNeil Generating Station. In 1979, C.T. Main was hired to design the plant and to help with the permitting requirements and construction management. The station was sited on a parcel of land known as the Intervale on the north side of Burlington. In September 1981, permits were received and site preparation began.

By October 1983 the ESP and steel building structure were essentially completed. Construction of the main power boiler began in August 1982; the boiler was hydrotested in April 1983. The turbine-generator set, manufactured in Switzerland, arrived in May 1983 and was first operated in January 1984. On June 1, 1984, the McNeil Generating Station began commercial operation, producing power as dispatched by New England Power Exchange.

The final cost of constructing McNeil was \$67 million (1984 dollars)— \$13 million below the budget estimate of $\$ 80$ million. The McNeil Station is jointly owned by BED (50\%), Central Vermont Public Service Authority (20\%), Vermont Public Power Supply Authority (19\%), and Green Mountain Power Corporation (11\%).

\section{Advanced Renewable Technology Development}

\section{Vermont Gasification Project}

In August 1994 the U.S. Department of Energy (DOE) entered into a cooperative agreement with Future Energy Resources Corp. and an industrial and utility consortium to design, construct, and validate large-scale integrated gasifier and gas turbine combined cycle technology at the McNeil Station. The "Vermont Gasification Project" is testing and operating an indirect biomass gasifier developed by Battelle Columbus Laboratories. During the initial operating phase (ongoing), the gas produced by the gasifier is burned in one of the natural gas burners of the McNeil boiler. Upon successful demonstration of the gasifier, a hot gas cleanup system and a commercial-scale $\left(15-20 \mathrm{MW}_{\mathrm{e}}\right)$ gas turbine will be incorporated into the system.

The Battelle gasification process is an indirectly heated CFB system that has more than 20,000 successful hours of operation at Battelle Columbus at the $10 \mathrm{t} / \mathrm{d}$ pilot plant scale. Wood or other biomass is gasified with a mixture of steam and hot sand. Hot medium-Btu gas leaves the gasifier with the sand and a small amount of charred wood. The sand is captured and recycled, while the charred wood is combusted in an FBC that provides heat 
to reheat the sand, generate steam, and dry wet wood. Capital costs are expected to be low as the process operates at low pressures without the requirement of an oxygen plant.

Various problems have been encountered in the attempts to operate the scaled-up gasifier at the McNeil plant, but progress is being made. About 18 months after the completion of construction, the unit has not yet operated continuously for a sustained period of days or weeks. The specific problems that have been encountered have not been disclosed, and work is ongoing. Some major changes were made to the gasifier in late 1998, and funding is available to continue with the project for at least one more year.

\section{Burlington EcoPark}

Burlington is planning an environmentally acceptable industrial park adjacent to the McNeil Station to use waste heat from the cooling system of the plant. This park will encourage agriculturally based industries to locate there, which will hopefully create by-products that can be used as fuel at McNeil. Funding has been finalized for this project, and the design phase is underway.

\section{Salix Project}

More than 5000 short-rotation energy crop trees have been planted at the McNeil site to determine their success in the Vermont climate. These trees include willows and poplar trees of various species.

\section{District Heating}

Feasibility studies are being completed for installing a district heating system to use the environmentally acceptable energy from the McNeil Station. This system would initially provide heat for the University of Vermont campus 1 mile from McNeil. The system would be expanded to include many other concentrated heating loads in Burlington.

\section{Outlook}

After more than 14 years of successful commercial operation, the outlook for the McNeil Station is uncertain. On September 15, 1998, the Vermont Public Service Board opened Docket No. 6140, "Investigation into the Reform of Vermont's Electric Power Supply." The four utilities that own the McNeil Station (the "joint owners") have different considerations and may pursue different strategies with respect to deregulation and competition in the electric power industry. The joint owners are preparing to conduct an analysis of the present and future value of the McNeil Generating Station and its associated activities. They may take a broad view of investigating the economic values attributed to the McNeil Station (e.g., environmental benefits, sustainable forest harvesting, participation in DOE-sponsored R\&D such as the Salix short rotation woody crop project and the Vermont Gasification Project, local economic benefits, emerging green power markets, and contribution to meeting climate change goals).

Burlington Electric Department's submittal to Docket No. 6140 suggested the need for increased access to transmission capacity for the McNeil Station, which would enhance McNeil's ability to sell more renewable power in the region and mitigate its costs. BED advocates an aggressive Vermont policy on renewable energy, especially "native Vermont renewable energy" such as that generated by the McNeil Station. Included would be a 
renewable portfolio requirement as a precondition to retail choice in Vermont, and creation of competitive "green markets" that use indigenous resources.

\section{Plant Flowsheet and Design Information}

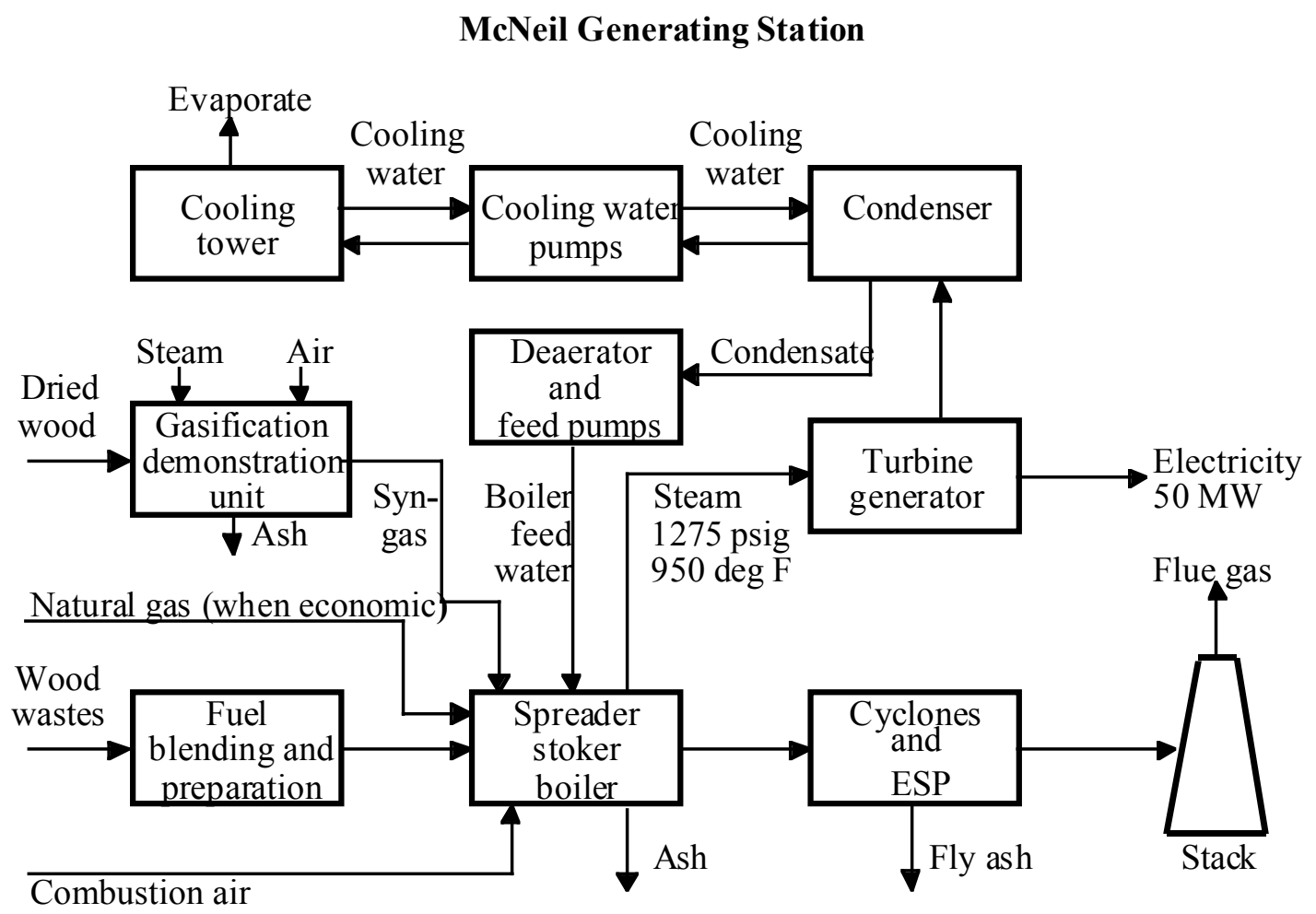

Boiler

The boiler, a two-drum, top-supported Sterling design with water wall construction, was furnished and erected by Zurn Industries. It was originally designed to be capable of PC firing in the future. Initially, three oil burners were installed for startup and flame stabilization with a maximum heat input of $250 \mathrm{MBtu} / \mathrm{h}$. Provisions were made for an additional three burners for future consideration. The boiler has two traveling grates and is rated at $480,000 \mathrm{lb} / \mathrm{h}$ at $1275 \mathrm{psig}$ and $950^{\circ} \mathrm{F}$ when burning $100 \%$ wood at $55 \%$ moisture content.

\section{Turbine Generator}

The turbine generator for the McNeil Station was manufactured by Brown Boveri Corporation in Oerlikon, Switzerland. It has 36 stages of rotating blades, five extraction points for feedwater heating, and 25-in. last stage blades. The turbine is directly connected to a 3600-rpm air-cooled generator rated at 60,037 MVA. The turbine generator was specifically designed to accommodate the cycling service expected at the station, as well as possible future district heating capability. The turbine generator set can supply a maximum of $59.4 \mathrm{MW}$ gross when exhausting $348,000 \mathrm{lb} / \mathrm{h}$ of steam to the condenser at $2 \mathrm{in}$. of mercury. Approximately 42,000 gpm of cooling water are required. 


\section{Cooling Water}

The McNeil site is approximately 1 mile from Lake Champlain. During the design phase, analyses were done to compare obtaining cooling water for the station from Lake Champlain versus an onsite cooling tower. Economically, the options were very close. A cooling tower was selected primarily for environmental considerations. A two-cell mechanical draft counter flow cooling tower was purchased from Research Cottrell. The tower handles a cooling water flow of $44,000 \mathrm{gpm}$ and a $71^{\circ} \mathrm{F}$ ambient wetbulb temperature for thermal design conditions.

\section{Ash Removal}

Flue gas is cleaned via a bank of cyclones and an ESP. Combined particulate removal efficiency is about $99.9 \%$, and particulate emissions are typically about $0.0007 \mathrm{gr} / \mathrm{dscf}$. The unit generates approximately $5000 \mathrm{t} / \mathrm{yr}$ of ash; approximately $10 \%$ of this ash comes from the bottom ash pit. The cyclones capture $65 \%$ and the ESP accounts for the remaining $25 \%$. The ash is mixed with agricultural-grade limestone and used as a soil conditioner for farmlands.

\section{Fuel System}

The on-site processing of wood is limited to magnetic separation of tramp metal and grinding of oversized wood feed. Fuel chips are stored in an open pile ( $\sim 30$ days supply, $\sim 7$ acres), fed by conveyor belt through an electromagnet and a disk screen, then fed to the surge bins above the boiler by belt conveyors. From the surge bins the fuel is metered into the boiler's pneumatic stokers by augers.

\section{Staffing}

McNeil Station has a full-time staff of 39 employees, including four foresters and 20 operators.

\section{Fuels}

An average of $70 \%$ of the wood fuel used by the plant consists of whole tree chips from low-quality trees and harvest residues that are cut and chipped in the forest, and transported by trailer truck to the station or to a railcar loading site in Swanton, Vermont. Wood chips may be obtained from any forestland where low quality trees are found. Most of these wood lots are privately owned, although timber is also purchased from large land holding companies, wood product manufacturers, and wood sales on public lands.

Approximately $25 \%$ of McNeil's wood requirements are met by sawmill residues. Mill chips and bark are purchased from local sawmills. The amounts of sawdust and mill residues burned at the McNeil plant have increased in recent years, with the reduced number of Vermont farms that use sawdust for bedding material. The McNeil plant also receives approximately $5 \%$ of the fuel requirements in the form of clean urban wood waste from the surrounding area.

Approximately $60 \%$ of the wood used by the station is hardwood and $40 \%$ is softwood. Approximately two-thirds of the wood supply comes from Vermont; the balance comes from New York, Quebec, and occasionally from New Hampshire and even Massachusetts. The McNeil Station also has a trial onsite plantation where short rotation energy crops are grown as future fuel for the McNeil Station. 
Based on figures published by the U.S. Forest Service, $50 \%$ of Vermont's forest inventory is made up of wood, branches, and bark that have no potential for manufacturing quality products such as woodenware or furniture. This unusable wood largely consists of tops and cull portions left behind after trees have been conventionally harvested as sawlogs or pulpwood. The amount of wood available for whole tree chip harvesting has been conservatively estimated at 1 million green $\mathrm{t} / \mathrm{yr}$ in Northern Vermont alone. This is twice the forecasted need to operate the McNeil Station annually at an estimated $70 \%$ load factor.

Wood for the McNeil Station is harvested under strict guidelines developed in conjunction with the State of Vermont. Burlington Electric is required to have four professional foresters on staff to supervise the procurement. Every harvesting site and harvesting plan is reviewed by a forester and approved by the state before the trees are cut. The foresters ensure that the wood is cut in such a way as to minimize any adverse effects on wildlife and the land, while optimizing regrowth potential.

Clearcuttings are generally limited to areas where the trees are of very poor quality. It may also be used in some cases to promote wildlife habitat. In these cases, the size of the area is limited to a maximum of 25 acres. Clearing is used in cases where the land is converted to other uses such as development, agriculture, or tree planting.

The Vermont Public Service Board required that $75 \%$ of all wood fuel be delivered by rail to McNeil Station. Burlington is the largest city in Vermont and there were concerns about traffic congestion from the trucks bringing wood to the station. A typical wood truck carries 25 t of wood, so three truck loads of wood are required for every hour the plant is operating at full load on wood fuel.

A remote wood yard is located in Swanton, Vermont, 35 miles from Burlington and 8 miles from the Canadian border. Seventy-five percent of the station wood is delivered to Swanton by truck. This wood is stored temporarily and loaded into 21 bottom dump gondola railroad cars. Each car can carry 75 tons of wood chips, or $7000 \mathrm{ft}^{3}$. At the McNeil Station, the railcars are unloaded three at a time through an unloading trestle.

Wood chip costs depend on such factors as the distance from the point of delivery, the type of material (such as bark, sawmill residue, or whole tree chips), and the mode of transportation. Chips delivered directly to the plant by truck are less expensive than those delivered to the Swanton site and shipped by railcar to the McNeil Station. The range of prices is $\$ 10-\$ 23 / \mathrm{t}$ delivered ( $\$ 20-46 / \mathrm{dt}$, or $\sim \$ 1.20-\$ 2.70 / \mathrm{MBtu})$. Shipping wood in by rail imposes an estimated $17 \%$ premium on the delivered fuel cost.

After an initial experience with over-storage onsite, which led to serious odor problems and spontaneous combustion in the wood piles, the plant developed a very tight management plan for on-site wood chip storage and handling. Piles are limited in size and are monitored to ensure that they do not reach the odor-producing stage. Fuel is consumed on a first-in, first-out basis to control the age of the material. 
McNeil Station is currently economically dispatched by NEPOOL on a least energy cost basis. As a result, McNeil Station cycles according to alternative fuel pricing, competitive unit availability, and New England energy demands. McNeil has cycled as often as 210 times annually. The unpredictability of dispatch greatly complicates fuel procurement.

In 1990, the City of Burlington established a waste wood recycling facility at McNeil Station. Residents of Burlington brought their tree trimmings and leaves to the station instead of to the landfill. Approximately $1300 \mathrm{t}$ of leaves are composted and spread on farmlands. Approximately $3000 \mathrm{t}$ of waste wood were processed annually and added to the McNeil fuel supply. In 1993 the recycling facility was made available to members of the Chittenden County Solid Waste District, which increased the waste wood supply to 5,000 t/yr. During 1998, approximately 20,000 t of fuel were received from the waste wood recycling facility. The increased capacity was because of a major ice storm in January 1998.

In 1989, the ability to burn natural gas was added to McNeil Station. Summer pricing for Canadian gas was at one time more attractive than wood prices. Having an additional fuel somewhat simplified the fuel procurement/consumption variations. Six fossil fuel burners were installed allowing full load capability on gas and $15 \mathrm{MW}$ capability on No. 2 oil. When gas burners were first installed the state $\mathrm{NO}_{\mathrm{x}}$ emission limits could not be met. A flue gas recirculation system was added which reduced the $\mathrm{NO}_{\mathrm{x}}$ emissions from $0.32 \mathrm{lb} / \mathrm{MB}$ tu to $0.1 \mathrm{lb} / \mathrm{MBtu}$, well below the standard of $0.13 \mathrm{lb} / \mathrm{MBtu}$.

The annual wood consumption has varied from a maximum of 460,000 $\mathrm{t}$ in 1985 to a minimum of $125,000 \mathrm{t}$ in 1986 . After full load capability on natural gas became possible in 1990, about two-thirds of the fuel requirements were met by wood and one-third by gas until gas prices rose during the mid-1990s. During 1997 and 1998, the McNeil Station burned almost no natural gas, and burned about 260,000 t/yr of wood (assuming 50\% moisture).

\section{Operating Experience}

Following the initial startup, most O\&M challenges resulted from the cycling operation of the plant and uncertainty of fuel requirements. Lower dispatch than anticipated caused wood inventory to grow to more than $100,000 \mathrm{t}$ in 1985. Some of the wood on site was more than a year old and was badly deteriorated. The smell from the wood was objectionable to neighbors. The older wood became very acidic, which caused steel components in the wood handling system to wear faster than anticipated.

A misalignment of the boiler grates during erection caused high maintenance in that area. The almost daily cycling of the unit resulted in higher maintenance in the ESP when carbon-rich ash on the collecting plates would burn when exposed to fresh air after shutdown. Despite these difficulties, the station has maintained an average availability of more than $90.9 \%$ since June 1984.

\section{Environmental Performance}

The air quality permit for the McNeil Station limited the particulate emissions from the stack when burning wood to $0.007 \mathrm{gr} / \mathrm{dscf}$ of flue gas corrected to $12 \% \mathrm{CO}_{2}$. This was far more stringent than any solid fueled source licensed at the time. To meet these requirements, GEESI supplied and erected 50-in. diameter mechanical cyclone collectors 
and a nine field-weighted wire ESP with an overall efficiency of 99.5\%. The design gas velocity in the precipitator was limited to $3 \mathrm{ft} / \mathrm{s}$, resulting in more than 7 acres of collection plates.

In actual operation, the stack particulate emissions are about $0.0007 \mathrm{gr} / \mathrm{dscf}$. This is $10 \%$ of the state requirements and about $1 \%$ of the $0.1 \mathrm{lb} / \mathrm{MBtu}$ particulate standards that were typical of solid fuel stations built when McNeil was built.

The chimney at McNeil is a precast concrete design with a $10-\mathrm{ft}$ diameter corten liner. It extends $257 \mathrm{ft}$ above grade with a platform midway for monitoring opacity, $\mathrm{CO}_{2}, \mathrm{O}_{2}, \mathrm{SO}_{2}$, flue gas flow, moisture, and $\mathrm{NO}_{\mathrm{x}}$. In addition, $\mathrm{CO}$ is monitored at the boiler gas outlet.

The plant's location is less than ideal. It is adjacent to a residential neighborhood of a metropolitan area. The topography is such that the top of the boiler is at about the same elevation as some residences on a nearby hill. Truck traffic, noise, odors, and emissions were problems during project planning and initial operations.

Ash produced from McNeil Station is temporarily stockpiled on site in a landfill area. A private contractor reclaims the ash, mixes it with agricultural-grade limestone, and markets it as a soil conditioner for farmlands.

Water removed from the McNeil Station is monitored for $\mathrm{pH}$, temperature, flow, and metals. It is treated to maintain a balanced $\mathrm{pH}$, allowed to cool to a temperature that will not adversely affect aquatic life, then pumped to the Winooski River, located about $1000 \mathrm{ft}$ east of the plant. The wastewater quality is required to be equal to or better than that of drinking water before being discharged to the river.

\section{Economic Information}

The plant cost approximately $\$ 67$ million to build, or $\$ 1340 / \mathrm{kW}$, in 1984 dollars. Adjusted using the GDP deflator, this is about $\$ 2080 / \mathrm{kW}$ in December 1998 dollars. The interest rate on the municipal bonds that financed BED's 50\% share of the plant in the early 1980s was about $12 \%$. The bonds have been refinanced three times, a costly process. O\&M costs total about \$4 million/yr, including \$1 million/yr in local property taxes. Spread over the annual plant output of about 155 million $\mathrm{kWh} / \mathrm{yr}$, O\&M costs are about $2.6 \phi / \mathrm{kWh}$.

Fuel costs depend on market prices and the amount of fuel used to meet NEPOOL dispatch requirements. In late 1998 , the price of natural gas was $\$ 2.80-\$ 3.00 / \mathrm{Mbtu}$, so gas was not used. Wood fuel cost varied between about $\$ 1.30$ and $\$ 1.70 / \mathrm{MBtu}$, which at a net plant heat rate of $14,125 \mathrm{Btu} / \mathrm{kWh}$ was equivalent to $1.8-2.4 \varnothing / \mathrm{kWh}$.

\section{Lessons Learned}

John Irving, the station superintendent, believes that the primary lesson learned from the McNeil plant experience is careful attention to the siting of a biomass-fueled plant. The plant's site has caused a number of problems and extra expenses over the years: a permit requirement to use trains for fuel supply, high taxes, high labor rates, local political involvement, and neighborhood complaints about odors and noise. There are advantages of an urban setting, such as the ability to obtain urban wood wastes. Although Burlington's urban wood waste supply is a small fraction of the plant's fuel requirement, it effectively lowers the average cost of fuel and avoids costly and environmentally poorer choices for 
disposing of this material. Linking the plant's steam output to a district heating system has been studied, but has not yet been implemented because of low alternative energy costs causing marginal economic benefits. Generally speaking, it is best to site a biomass plant as close as possible to the center of its fuel supply, and far from residential neighborhoods.

Another lesson learned at McNeil was that the long-term fuel contracts insisted on by the financing institutions can create some costly problems. As required, McNeil had 15 or 20 long-term fuel contracts when it started up, and enjoyed a good first year of operation with a 70\%-80\% CF. When the CF dropped during the second year as a result of NEPOOL dispatch requirements, the fuel kept coming and the plant fuel yard was awash in wood chips. The resulting lawsuits and settlements with the fuel suppliers were expensive, and the odors emanating from the aging wood piles became a major nuisance for the neighbors. After working through these problems, the plant now runs more economically and flexibly by buying wood fuel with a series of short-term contracts, thereby avoiding long-term commitments and expensive spot market pricing.

\section{Sources and Contacts}

John M. Irving

McNeil Station Superintendent

Burlington Electric Department

585 Pine Street

Burlington, VT 05401

Phone: 802-865-7482 Fax: 802-865-7481 


\section{WHEELABRATOR SHASTA ENERGY COMPANY, ANDERSON, CALIFORNIA}

Wheelabrator Shasta Energy Company or "Shasta," an affiliate of Wheelabrator Environmental Systems Inc., manages a 49.9-MW (net) wood-fired power plant in Anderson, California (about 140 miles north of Sacramento, just south of Redding). The plant processes about 750,000 t/yr of mill waste and forest residues from Shasta County and surrounding areas. The plant, which has three Zurn traveling grate boilers, became operational in December 1987. In 1996 the plant produced 418 million $\mathrm{kWh}$ of electricity for sale to Pacific Gas and Electric Company (PG\&E) under a Standard Offer \#4 contract. The 10-year fixed price portion of the contract expired on April 30, 1998.

\begin{tabular}{ll}
\multicolumn{2}{c}{ Vital Statistics } \\
\hline $\begin{array}{l}\text { Design capacity, net MWe } \\
\text { Configuration }\end{array}$ & \multicolumn{1}{c}{49.9} \\
& 3 traveling grate stoker boilers \\
\hline Fuels & Mill wastes \\
& Forest residues \\
& Agricultural residues (shells, prunings) \\
& Urban wood wastes \\
& Natural gas \\
Net heat rate, Btu/kWh & 17,200 \\
Thermal efficiency, HHV, \% & 19.8 \\
Net generation, MWh/year & 418,000 \\
\hline
\end{tabular}

\section{History and Outlook}

Shasta was formed to manage one of Northern California's most modern independent wood-fired power plants. Engineering and equipment procurement started in June 1986, and construction started at the site near Anderson, California, in November 1986. The plant became operational in December 1987. The project owner and operator is Wheelabrator Environmental Systems Inc. The owner's engineer was Rust International Corporation. Construction financing was provided by Ford Motor Credit Lease, and long-term financing was provided by Citicorp USA.

The 49.9-MW (net) plant processes about 750,000 t/yr (350,000-400,000 dry t/yr) of mill waste and forest residues from Shasta County and surrounding areas. Redding is the main milling center for timber produced in Northern California. Unmerchantable wood wastes from Shasta-Trinity and Lassen National forests, as well as from private lands in the area, are selectively removed and processed to improve remaining standing timber. 
The plant produces more than 400 million $\mathrm{kWh}$ of electricity/yr for sale to PG\&E under a Standard Offer \#4 contract. The plant design includes three independent wood-burning units, composed of three state-of-the-art wood-fired traveling grate furnaces with utilitytype high-pressure boilers. The highly automated wood yard design includes capabilities to accept mill wastes, chips, and unmerchantable whole logs (culls) as large as $6 \mathrm{ft}$ in diameter, which are chipped on site for fuel.

Shasta has shown excellent performance. On-peak availability has been $100 \%$ since January 1, 1989, and overall availability exceeded 99\% during 1995 and 1996. The annual $\mathrm{CF}$ in 1996 was 95\%. The net plant heat rate is about 17,200 Btu/kWh (about 19.9\% thermal efficiency based on HHV). The furnaces are specially shaped and have staged overfire air to reduce $\mathrm{NO}_{\mathrm{x}}$ emissions. Particulate emissions are controlled by highefficiency ESP.

Like the other California biomass power plants with Standard Offer \#4 contracts, Shasta receives special payments collected from electricity customers and distributed by the California Energy Commission (CEC) during the 4-year transition period to a restructured electric industry (1998 through 2001). The California legislation (AB 1890) that established this support system for extant renewable energy power plants also tasks the state Solid Waste Management Board with developing a fuel "cost shifting" strategy that would place the cost burdens more equitably on those who receive the direct benefits (e.g., the farmers and foresters who produce biomass residues and sell them as fuel). Through these programs, the owners of biomass plants in California hope to make a successful transition to the new world of competitive electricity markets.

\section{Plant Flowsheet and Design Information}

\section{Boilers}

The plant has three Zurn traveling grate, staged combustion furnaces that consume about $100 \mathrm{t} / \mathrm{hr}$ of mill waste and forest residues at $50 \%$ moisture. The membrane waterwall boilers each produce about $170,000 \mathrm{lb} / \mathrm{h}$ of steam at $900 \mathrm{psig}$ and $905^{\circ} \mathrm{F}$.

\section{Turbine Generators}

The plant has three Elliott condensing turbine generators. Heat is rejected through three surface condensers with two multicell evaporative cooling towers. 


\section{Plant Flowsheet and Design Information}

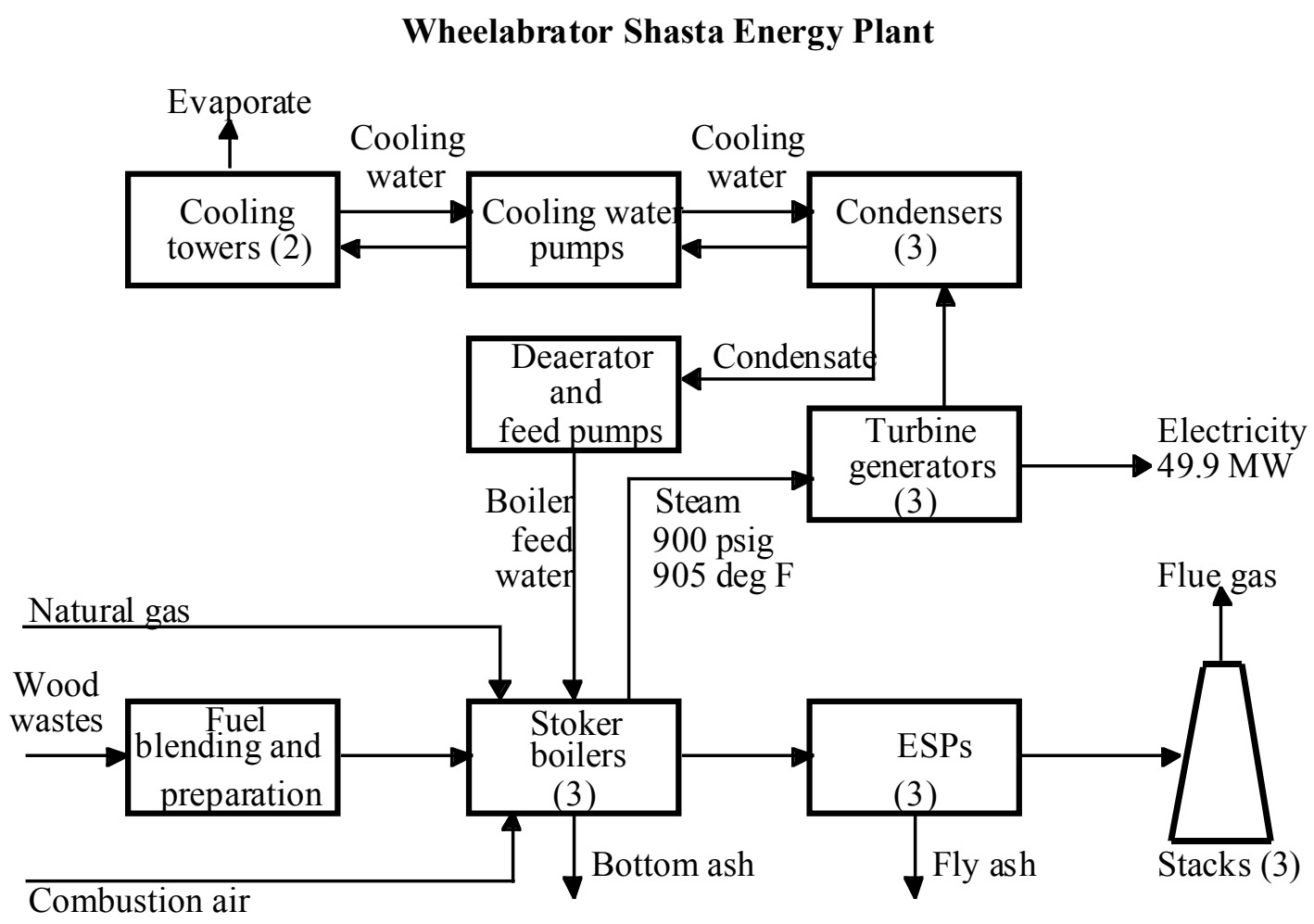

Fuel System

The fuel receiving and processing system consists of two truck scales, three platform truck dumpers, one hydraulic log loader, one 24-in. knife chipper, and one 72-in. drum chipper, and infeed/offload conveyors. The fuel storage and reclaim system includes one 50-ft high stacker with two $130 \mathrm{t} / \mathrm{hr}$ overpile reclaimers (each $1100 \mathrm{ft}$ long), one log debarker, and 50 $\mathrm{t} / \mathrm{hr}$ hammerhog, scalpers, and conveyors. On average, the plant must unload a chip van of fuel every $15 \mathrm{~min}, 24 \mathrm{~h} / \mathrm{d}, 7 \mathrm{~d} / \mathrm{wk}$, to fuel the plant.

\section{Emissions Control}

The furnaces are specially shaped and have three stages of overfire air injection; in addition, ammonia $\left(\mathrm{NH}_{3}\right)$ is injected into the flue gas to control $\mathrm{NO}_{\mathrm{x}}$ emissions. The plant has three, three-field, high-efficiency ESP to collect fly ash. Collected fly ash is spread on farm fields and bottom ash is used as road base. The staged cooling towers provide for zero water discharge from the plant.

\section{Plant Control}

The plant has a Bailey computer-based distributed control system with multiple CRTs. 


\section{Staffing}

The plant provides full-time employment for about 45 people. Over the years the operating staff has been reduced by about eight positions. The plant generates related local employment for more than 125 people to supply, transport, and handle fuel.

\section{Fuels}

Maintaining adequate fuel supply in the midst of a declining regional timber industry has been, and will continue to be, the single biggest challenge for Shasta. By 1991, competition for fuel had become intense, with more than $400 \mathrm{MW}$ of wood-fired capacity in the region chasing perhaps $200 \mathrm{MW}$ worth of mill waste. The remainder had to flow directly from the woods and farms, bypassing the milling operation, or appear as plant output curtailments, which became typical for many plants during off-peak periods. Battles between the logging industry and environmentalists over the spotted owl and other issues caused the wood fuel availability situation in the region to continue to deteriorate.

Almost from startup, Shasta has attempted to diversify its fuel sources and reduce its demand for wood fuel. From an initial list of permitted fuels that included only mill waste, logging/thinning residue and cull logs, Shasta had added the following to its permitted fuel list by January 1992:

- Agricultural residues such as almond, walnut, and pistachio shells.

- Orchard prunings and removals.

- Hog fuel from eucalyptus and poplar plantations.

- Hog fuel from clearing of PG\&E and public road rights-of-way.

- Hog fuel from permitted land development projects (roads, subdivisions).

- Fuel from commercial tree trimming companies.

- Fuel from yard waste processing operations.

- Fuel from city, county, and state tree trimming activities.

In addition to expanding its list of fuels, Shasta revamped its cull log chipping system to begin producing salable paper chips from usable portions of the cull log. Previously, the cull, or unmerchantable, logs purchased were chipped totally into fuel. In times of high chip prices, however, Shasta was priced out of the cull log market as the logs were debarked and chipped elsewhere for paper chips, primarily for the Japanese market. With the addition of a debarker, high-speed V-drum chipper, chip screen, and overhead bins, Shasta could offer to custom chip logs, keeping the 35\% of the log not suitable for chips. In times of low chip prices, Shasta purchases the whole log. Shasta successfully marketed the program to some of the largest landowners in California.

To reduce wood fuel use, Shasta:

- Purchased, rather than produced, off-peak auxiliary power from PG\&E, breaking even on cost and eliminating $7 \%$ of its fuel demand.

- Purchased natural gas under long-term contract, supplemented by spot purchases, that displaced $12 \%-20 \%$ of its wood fuel demand.

- Tested and implemented a fly ash reinjection system on all three boilers, lowering fuel demand by $3 \%-4 \%$.

Expanding the list of fuels because of wood fuel shortages placed a decided burden on the plant's fuel quality program. The fuel mix that evolved, compared to the design fuel mix, had a much greater variation in density, size, and moisture content. In addition, the fuels 
were much dirtier and Shasta was taking more risks with respect to ash properties. The operators learned to blend all the fuels into a homogeneous mixture that allowed the boilers to fire at a consistent rate and maintain maximum load under all conditions, without violating tight environmental standards, excessively corroding heat transfer surfaces, or slagging beyond the point where the boilers required cleaning more than twice per year. Shasta accomplished this via fuel contracting and monitoring practices, operating practices, and equipment selection.

Fuel contracts contain sliding scales of prices base on moisture content, encouraging suppliers to provide as dry a fuel as possible. Contracts are on a delivered price per BDT, forcing the supplier to pay the higher freight on a wet load. Contracts specify maximum percentages of contaminants and fines that will be accepted at full contract prices, and prohibit any material that cannot be accepted under the plant's permits, because of either quality or fuel source.

The fuel receiving, moisture determination, and contract payment functions are all tied together in a single computer program. All data are entered from electronic displays so no transposition of numbers is possible. Separate computer databases are maintained for suppliers, fuel types, carriers, and contracts so all loads are cross-matched to ensure the plant receives the fuel contracted for, it is traceable for permit purposes to an approved source, and it is paid for under correct contract terms.

Once the fuel is received and sampled, the blending process, which is the key to stable operation, begins. The first blend occurs in the three truck dumps that discharge onto a common belt conveyor. A particularly wet load, for instance, can be held until drier material is delivered to the other dumps.

A second blend occurs when the bark, fines, and overs from the cull log chipping operation dump onto the conveyor carrying the truck delivered fuel. Cull log decks are filled by winter, so maximum winter chipping can be done when chip prices are typically higher and the need for the drier cull log fuel is greatest. The combined streams then pass over a disk screen that sends the larger pieces to a hammermill and bypasses the finer material. The two streams are then combined again on the belt feeding the stacker.

Before being delivered to the stacker, a third blend occurs when the boiler return fuel is added to the stacker belt. Typically, $15 \%-20 \%$ of the total fuel sent to the boilers is returned to the stacker to ensure adequate fuel is available at all times to handle boiler swings.

The automated stacker runs on a $1000-\mathrm{ft}$ long track and can stack 40-ft high windrows on each side of the track. Prudent use of the stacker piles can mean that perhaps $80 \%$ of all fuel received annually is never touched by mobile equipment, but some fuel must be pushed to dead storage beyond the reach of the reclaimers and then pushed back to even out the seasonality of the forest products industry. By pushing fuel out to inventory in the fall, and reclaiming it during the winter and early spring, Shasta can stay within the 6-month fuel rotation requirement of Shasta County and prevent spontaneous combustion fires. 
Reclaiming the fuel with automated overpile reclaimers presents two additional opportunities for blending. The reclaimers have a different pivot point than the stacker, so they cut across numerous loads of fuel in the process of pulling the fuel in. The use of both reclaimers simultaneously presents the opportunity to blend fuel from the two windrows continuously. During heavy rainfall periods, the reclaiming runs can be shortened and the reclaimer moved to steep sections of the pile so as little surface area of the pile as possible per ton reclaimed is exposed to rainfall.

The result of these above blending opportunities is a very homogeneous fuel blend going to the boilers from a very heterogeneous mix of incoming fuel. Typically, the boilers can hold full load continuously while maintaining a header pressure of \pm 2 psig.

The fuel variety and sources were not expanded without problems, however. Simultaneous combustion of natural gas and almond shells created a higher than normal superheater inlet gas temperature; this, combined with the low melting point of shell ash caused by high potassium content, created a corrosive environment in the secondary superheater. This was countered by segregating the almond shells and burning them only when the gas burners are not in use.

The increase in fuel contamination (dirt, sand, and gravel) led to accelerated wear on the fuel feeder screws and drop chutes and to additional problems with the traveling grates. Also, clinkering in the furnace increased with the increase in contamination, but Shasta has been able to maintain a twice yearly cleaning schedule.

Fuel from a Short-Rotation Woody Crop

Simpson Timber Company in Corning, California, has established a 10,000-acre eucalyptus plantation called the Tehama Fiber Farm about $44 \mathrm{mi}$ from the Shasta plant. Hybrid eucalyptus are being grown at very high rates using drip irrigation and fertilization. The first block of trees was planted in 1989, and the first harvests took place in 1997 (an 8year rotation). Pulp chips go to the Simpson Paper Company's pulp mill, and fuel (ground bark, tops, and limbs) goes to the Shasta plant. Once the plantation reaches a mature steady state it could provide a substantial portion of Shasta's fuel. The future of the fiber farm is somewhat in doubt, however, because Simpson has the paper mill up for sale. Also, the fiber farm is working on ways to convert portions of the fuel fraction to higher value products, such as feedstock for eucalyptus oil manufacture. Success in this area would reduce the amount of fuel provided by the fiber farm.

\section{Operating Experience}

Shasta has shown excellent performance. On-peak availability has been $100 \%$ for 8 straight years, and overall availability exceeded 99\% during 1995 and 1996. The annual CF in 1996 was $95 \%$. The net plant heat rate is about $17,200 \mathrm{Btu} / \mathrm{kWh}$ (about $19.9 \%$ thermal efficiency based on HHV).

Shasta has improved operations and reduced costs in several ways:

- Markets have been developed for all of the ash. Fly ash is used as soil amendment on farm land, and bottom ash goes to developers who use it as road base. The plant pays only part of the freight cost for delivery of the ash, rather than the much higher disposal costs it paid previously. 
- The cost of operating the plant's zero water discharge system, which uses staged evaporative cooling towers, has been reduced by using some of the water for onsite irrigation and natural evaporation.

- A large hammermill was added to the fuel processing system to allow the use of a broader range of fuels. This has reduced fuel costs by allowing the plant to process "opportunity fuels" such as railroad ties, brush, prunings, etc.

- The payroll has been reduced by about eight people. The total staff, including management and office personnel, is now 45 people.

\section{Environmental Performance}

The plant has complied with all permit requirements.

\section{Economic Information}

Not provided.

\section{Lessons Learned}

Bill Carlson, vice president and general manager, Western Region, Wheelabrator Environmental Systems, Inc., provided the following discussion of "lessons learned in burning biomass" in a presentation to the 1995 NBIA/UBECA Joint Annual Meeting. These lessons were derived from Wheelabrator's experience in operating biomass plants for 10 years in California, Maine, and Florida:

- "Never put your faith (and dollars) behind someone's official natural gas price projection, particularly when that agency is trying to help you.

- Never design a biomass plant thinking you know what your fuel is going to be. Design in flexibility of fuels, both in your capital equipment and in your permits.

- Always place a high value on reliability and dependability, for these will allow you to be considered a 'player' and thus a participant in the development of special programs with the utility.

- Beware of entering a regulatory system in which the utility commission or legislature has determined that it is acceptable for ratepayers to pay the full cost of your technology. Such things do not last.

- Never allow a fuel supply system to be developed in which you pay the Btu "value" of the fuel. Instead, participate in a system that starts with the assumption that you represent another waste disposal option.

- Other participants in the debate over future electric supply will grant that you have value in the system only when you are threatened with extinction, and only then while continuing to complain about your cost."

Mr. Carlson's 1995 recounting of the California biomass experience explains the basis for the six lessons above:

"Like others, we joined the rush to California following the passage of PURPA seeing gold in the high power rates and abundant biomass fuel supply. The state was most willing to help, offering 'standard offer' contracts with 10 years of escalating rates based on their lofty projections of avoided costs of natural gas followed by 20 years of the utility's actual short run avoided cost. This was teamed with front end loaded capacity payments for a truly seductive package. 
"Plants sprang up throughout the northern two thirds of California, numbering at peak more than 50 plants and totaling a capacity in excess of $800 \mathrm{MW}$. The fuel demand quickly outstripped the availability of cheap mill waste and agricultural processing waste, driving fuel prices steeply upward. Individual entrepreneurs invested in capital equipment to produce fuel from the forest, the urban waste stream, orchards and vineyards. These fuels were expensive to produce, but we could afford it, and many plants had agreed to burn such fuels in order to provide emission offsets in nonattainment areas. Many of us revisited our air permits regularly, constantly seeking to broaden the range of fuels that we could burn.

"Before the ink was dry on the contracts, natural gas prices collapsed, leaving our power well above market. This made renewable power an excellent whipping boy for the utilities, regulators, and politicians seeking to explain the high cost of power in California. This clamor culminated in the issuance of the Public Utilities Commission's Blue Book in early 1994, a proposal to restructure the electric utility industry in California. The original proposal called basically for a 'price only' system, throwing out previous purchase mandates and fuel diversity goals. It was a system in which we could not possibly survive.

"The Blue Book caused us all to re-examine the system of biomass energy that had evolved. By that time we were disposing of about $20 \%$ of all solid waste in California via combustion, we were providing substantial air quality benefits by eliminating burning of agricultural wastes and forest residues, and we were restoring forest health and lowering fire potential in substantial portions of California's forests. But far from collecting for those services from the parties benefiting, we were paying premium prices for the fuel and charging it all to the investor owned utility ratepayers. Not a system that could be sustained in the current political and regulatory climate.

"The shock of what appeared to be coming caused many biomass producers to accept utility buyout offers, and nearly 20 plants have since closed. This at least knocked fuel demand back in balance with supply, and prices are dropping rapidly. [Note: this was written in November 1995.] In addition, many of us participate in utility pay-for-curtailment programs, putting further downward pressure on fuel prices.

"As we organized to try and tell our side of the story, we found that we had accumulated a substantial number of friends over the years. We had integrated ourselves into the State's forestry, agriculture, and solid waste industries to the point that they rose to defend us at the PUC. State agencies as diverse as the Department of Food and Agriculture, Cal EPA, Air Resources Board, Forestry and Fire Protection, Integrated Waste Management, and the Energy Commission convened a summit to see what they could do to help us. Even environmental groups weighed in on our behalf because of the positive benefits we provided to forest practices in California. Clearly we had something positive going here, but we had certainly structured it all wrong when we placed the full burden of the system on the backs of ratepayers. 
"The original PUC proposal has gone through numerous iterations, and its final form is far from certain. [Again, in November 1995.] The biomass industry has introduced legislation that would create a competitive pool among biomass energy producers, driving down prices for biomass power. The pool would only have room for about two-thirds of current biomass power, making it imperative that you bid prices low to secure a spot. The pool would phase out in 5-7 years when we would be at 'market'. The transition period would give us time to eliminate debt and to restructure the fuel supply system to dramatically lower prices.

"We have no idea what the outcome will be to the debate in California, but we all certainly have a lot riding on it. My gut feeling is that we will indeed get some kind of a transition program, but will be in the open market within 5 years. [Note: a four-year transition program of support payments to renewable energy generators was created by the California Legislature, expiring at the end of 2001].

"The debate in California has also caused us to focus on our real strengths and weaknesses in a way we had not previously. As you all know, our real weakness is that the power is just too expensive. With ownership costs running 2.5 to $3 \notin / \mathrm{kWh}$ for a baseload facility and operation and maintenance costs of 2 to $2.5 \phi / \mathrm{kWh}$, the resulting 4.5 to $5.5 \phi / \mathrm{kWh}$ is not competitive today. And the above number includes no fuel costs.

"On the strengths side, we have a number of key items that we are relying on in the current debate:

1. Wood is truly a renewable, domestic resource, with no concerns about being held hostage by foreign energy suppliers and their governments.

2. Wood energy is primarily rural in nature, at a time when many seek to assist weak rural economies.

3. Wood energy can be added in small increments, matching the load growth of the local utility.

4. Wood energy creates more permanent jobs per MW than other technologies both at the plant and in the fuel supply infrastructure.

5. Wood energy is highly reliable and dependable for the utility. Plants average $95+\%$ annual CF. Our Shasta plant in Anderson, California just completed its seventh straight year of $100 \%$ summer peak CF.

6. Wood energy provides substantial air quality benefits, both globally and in the location of the plant. As opposed to field burning of agricultural and forestry residues, there are major reductions in particulates, $\mathrm{CO}$, and hydrocarbons.

7. The wood energy technology is exportable to developing nations, particularly those without other domestic sources of energy. Wood's small increment size and low technology make it particularly appropriate.

8. Solid waste recycling systems achieve better results when wood can be removed and sent to wood energy plants. In California, nearly $20 \%$ of all material is diverted for wood energy.

9. Agriculture has less public resistance to its activities when byproducts are sent to wood plants instead of open field burned. 
10. Forest management practices improve in effectiveness and drop in controversy when excess nonmerchantable biomass is removed to improve forest health and lower fire potential. Wood plants can mimic the role of natural fires.

"With the above list of strengths, and our only Achilles Heel being cost of power, this cries out for a new approach. We have thought long and hard about this and think that we may have an idea that could restart wood plant construction in the West, but on different, more sustainable terms. If you will indulge me, I will describe the concept.

“The New Approach...

"The forests of the Inland West are overgrown, sick and dying because of 80 years of suppression of natural fires. Without the periodic thinning provided by low intensity fires, the forest becomes choked with excess vegetation, in many cases 20-50 times the historic number of trees per acre. This condition exists on over 100 million acres in the West.

"At the same time, we are not addressing the issue because of the policy stalemate over the use of our public forests. Annual harvests are down 80\%-90\%, unemployment is high in the rural West, and many communities are suffering mightily as we endlessly debate the future of the public forests.

"After 60 years of declining numbers of annual acres burned in wildfires, the number has once again begun to rise. In 1994, over 4 million acres burned in the West and the suppression cost to the US Forest Service alone was over $\$ 1$ billion. And unlike the gentle, cleansing fires of 100 years ago, the excess vegetation today spawns massive raging fires that kill everything in their path, sterilizing the soil and which are virtually unstoppable. Today, a burned site may not be capable of supporting a future forest for several hundred years. The loss of high quality wildlife habitat is staggering.

"In California, the existence of a string of wood burning plants has spawned some new forest management techniques that address these issues. Combined with traditional sawmills and pulp mills, the wood burning plants provide a market for all of the products removed in a thinning operation, making such an operation economic for the first time. The landowner is now able to practice a reverse form of forestry, leaving the older, larger trees that historically populated the site while economically removing the excess vegetation that used to be consumed by low intensity fires.

"The result is a healthier, faster growing forest that has a dramatically lowered potential to be destroyed by fire. There is now adequate moisture, nutrients and sunlight for the remaining trees and net growth often triples. The remaining trees regain their traditional resistance to insect and disease attack.

"The results are dramatic. These thinning techniques have been practiced on over 500,000 acres of private and public land in California over 10 years and, as we found out in the restructuring debate, the results are heavily supported by the public, 
environmental groups, state and local government and public land managers. It is your classic win-win situation and would not have happened without the existence of the wood burning plants. This is a compelling story, and one that needs to be repeated over the West and, in actuality, in many other forested areas in the world.

"We have set out to do that, starting with a short term demonstration project in the Blue Mountains of Eastern Oregon, in the heart of some of the most severe forest health problems. But this time we want to start off differently, based on our lessons learned in California. Because of the benefits to the landowner and the public, we will expect the fuel portion to be delivered to the plant for free. The economics of the overall thinning operation will support that, as the higher valued sawlogs and pulp chips will pay for the thinning, plus give a return to the landowner, while paying for fuel processing and delivery. This takes care of our current California problem of high fuel costs.

"To eliminate capital costs for the demonstration project, we will start with an existing generating asset, a closed $6 \mathrm{MW}$ plant in Long Creek, Oregon. This will drop required power contract revenues down to $4 \varnothing / \mathrm{kWh}$ to run a break-even demonstration project. So far, we have only been offered about $2.8 \phi / \mathrm{kWh}$ for the power from the Bonneville Power Administration, and so we requested a grant from the Department of Energy for the difference under their Biomass Power for Rural Development RFP, but were turned down. We have forged ahead anyway, hoping to find a way to close this gap.

"The environmental aspects of the thinning will be studied by the Blue Mountain Natural Resource Institute and reports issued. We expect their work to be funded by environmental groups interested in the outcome. We expect to bring numerous elected officials, environmental groups, public land managers, the media and the public to the Blue Mountains to witness the results on the ground. We will discuss environmental benefits and economics at length. We expect the demonstration project to result ultimately in a policy shift toward such thinnings as a way to both protect and utilize our public forests while at the same time protecting and enhancing their environmental values.

"Particularly with elected officials, our discussions will center on how to cause these techniques, and the wood burning plants integral to their success, to spread throughout the West. With new capital investment, the plants will still need $5.5 \phi / \mathrm{kWh}$ to earn a reasonable return, a number still well above market. But, if the existing biomass production tax credit (currently under attack in the House) would be extended to this activity, that cost would drop to a competitive $3.5 \phi / \mathrm{kWh}$. We should be able, by this time, to demonstrate that the savings to the federal government, in terms of reduced land management and fire suppression costs, will be greater than any tax credits granted. The tax credit will hopefully only need to be for an interim period, since we were less expensive than natural gas before, and we will be again.

"Should this scenario play out as I described above, there will be a need for 100$150(30 \mathrm{MW})$ plants to accept the thinnings from activities on the lands needing treatment over the next 20-30 years. This is a significant boost to our industry. 
"These are our thoughts on how the biomass industry can go forward by integrating itself into other sectors of the economy, in this case forest products, and by being paid for the value it brings to the table with free fuel. There are undoubtedly other opportunities in linking with agriculture, solid waste management, or just to provide dispersed, small increment, reliable power to rural areas.

"But these new approaches must go forward on a very different basis than our past biomass developments. They must go forward in partnership with utilities. It is easy for a utility, for instance, particularly a rural utility, to grasp the value of the integrated forest products model I just described, to project the economic benefits to their service territory, and to appreciate the stability it brings to existing industry. While the utility may want to participate in such systems, they will not and cannot do so unless the cost to ratepayers is very close to that of other generating options. The future world is just too uncertain for them to take any other stance.

"So, we must use our lessons learned to design a system that gets the costs of our technology out of the pockets of those getting the benefits, and not out of the pockets of utility ratepayers. If we can do this, the biomass industry can indeed have a bright future. I hope that you will join us in pushing to get our demonstration project rolling next Spring and that you will monitor its progress. I hope that you will join us in pushing the concept of the expansion of the tax credit, but only at the time that we can demonstrate the value to the public at large of taking care of their lands with such a system, and when we can demonstrate that the US government will save more in management costs than it gives in tax credits."

\section{Sources and Contacts}

Most of the information in this section came from two conference papers written and presented by William H. Carlson, general manager, Alternate Energy Group, Wheelabrator Environmental Systems Inc.:

- Biomass Combustion Conference, Reno, Nevada, January 26-28, 1992. "Managing Fuel Quality at a Wood-Burning Power Plant," by William H. Carlson.

- Strategic Alliances for Biomass Energy, National Bioenergy Industries Association and Utility Biomass Energy Commercialization Association, Washington, DC, November 14-16, 1995. "Lessons Learned in Burning Biomass," by Bill Carlson.

A Wheelabrator Shasta brochure provided descriptive information on the plant, and Bill Carlson provided information by telephone in February 1997. Contact information:

William H. Carlson

Vice President \& General Manager, Alternate Energy Group

Wheelabrator Environmental Systems Inc., Western Regional Office

20811 Industry Road; P.O. Box 7000

Anderson, CA 96007-7000

Phone: 530-365-9172

Fax: 530-365-2035 


\section{SAN JOAQUIN VALLEY ENERGY PARTNERS, CHOWCHILLA, EL NIDO, AND MADERA, CALIFORNIA}

NRG Energy, Inc. of Minneapolis, Minnesota, and its partners own three biomass energy plants in central California near Fresno. The bubbling FBCs have burned more than 35 types of agricultural and wood wastes, including almond prunings, cotton stalks, corn stalks, vineyard prunings, straw, and forest residue fuels. Originally four plants were developed by CAPCO Energy, started up in 1988 through 1990, were bought by the present owners in July 1992, and shut down in March 1995 after negotiating a buyout agreement with PG\&E. Chowchilla I has been sold and dismantled. Chowchilla II, El Nido, and Madera remain in operable condition. The owners are soliciting offers for these plants, to be sold "as is, where is."

\begin{tabular}{lccc} 
& Vital Statistics \\
\hline & Chowchilla II & El Nido & Madera \\
Design capacity, net MWe & 10 & 10 & 25 \\
Configuration & Bubbling fluidized bed boiler \\
\hline Fuels & \multicolumn{3}{c}{ Agricultural residues (prunings, etc.) } \\
\multicolumn{3}{c}{ Forest residues } \\
Mill residues \\
Urban wood wastes \\
CF (peak/partial
\end{tabular}

\section{History and Outlook}

The four CAPCO facilities were built within a 25-mi radius in central California with their general office in the city of Chowchilla. (Chowchilla is on Highway 99 about 30 miles north of Fresno and about $20 \mathrm{mi}$ south of Merced. Madera is between Chowchilla and Fresno, and El Nido is about $15 \mathrm{mi}$ west of Chowchilla.) The Chowchilla I plant came on line in December 1987; El Nido in October 1988; Madera in July 1989; and Chowchilla II in February 1990. All operated under Standard Offer \#4 contracts with PG\&E, which provided a lucrative schedule of capacity and energy payments for a 10-yr period, following which the energy payments would be based on the utility's avoided cost.

The Chowchilla II, El Nido, and Madera plants use bubbling FBCs supplied by Energy Products of Idaho (EPI). Chowchilla I was a multi-hearth plant that gasified biomass, producing a low heat content gas that was used by the plant as a fuel for power generation. A by-product of the Chowchilla I gasification process was a charcoal-like substance that 
was used as fuel in other facilities. Chowchilla I was shut down in January 1991 because of various problems. The facility was refurbished by the new owners and returned to commercial operation in May 1994.

The facilities were permitted to burn more than 50 types of agricultural and wood wastes as fuel. Madera's air quality permit required that $25 \%$ of the plant's fuel be offset fuel (agricultural residues such as orchard prunings that would otherwise be burned in the field). The other plants' permits did not require a specific percentage of offset fuels.

In July 1992, NRG and its partners (San Joaquin Valley Energy Partners) bought the facilities. During the early 1990s, natural gas prices collapsed, and biomass fuel prices doubled or tripled in California. The cost of power from biomass facilities was much higher than the market price of energy in the utilities' systems. In October 1993, PG\&E asked the owners to curtail operations. Under this curtailment plan, the plants generated at full capacity during peak and partial peak periods, and reduced to minimum load during the off- and super off-peak periods on weekdays. The plants were taken off line on weekends and holidays. For 15 months these facilities demonstrated their generation flexibility as load following facilities.

In April 1994 the California Public Utilities Commission published its Blue Book, a proposal to restructure the electric industry in California. PG\&E offered to buy out the contracts of many biomass power plants. In general, these offers paid the plant owners more than they would make from continuing to operate under their contracts, while at the same time saving the utility money. San Joaquin Valley Partners accepted the utility's offer, transferring their power purchase agreements (PPAs) back to PG\&E on March 1, 1995. The plants were shut down and are being continuously maintained while being offered for sale. In the 3 years since, 16 biomass power plants in California, rated collectively at more than $200 \mathrm{MW}$, accepted buyout offers and shut down.

\section{Fluidized Bed Combustor Design Parameters and Advantages}

The fluidized beds operate at bed temperatures of about $1500^{\circ} \mathrm{F}$. Furnace temperatures above the bed are approximately $1700^{\circ} \mathrm{F}$. Average gas velocities in the bed are $8 \mathrm{ft} / \mathrm{s}$ and average velocities in the furnace above the bed are $10 \mathrm{ft} / \mathrm{s}$. Underbed air accounts for about $70 \%$ of the combustion air supply. Underbed average velocities are approximately $2 \mathrm{ft} / \mathrm{s}$. Bed energy densities are about $750,000 \mathrm{Btu} / \mathrm{ft}^{2}$. Static bed depth is maintained at $18 \mathrm{in}$. The expanded bed operates at 24 in.

Combustion performance of fluidized bed boilers is generally superior to that of stoker grate boilers using biomass fuels. The combustion is complete, in that very little char is present in the boiler fly ash. Normally the ash is light gray. Boiler operation is stable for biomass fuel; moisture content is 30\%-60\%. Fuel moisture content is controlled by mixing biomass wastes (as described in the Wheelabrator Shasta section). Better combustion air distribution is responsible for reduced $\mathrm{CO}$ and hydrocarbon emissions. $\mathrm{CO}$ emissions are typically $100 \mathrm{ppm} ; \mathrm{O}_{2}$ levels are $4.5 \%$.

Fluidized bed boilers burning biomass operate approximately $400^{\circ} \mathrm{F}$ cooler than do stoker grate boilers. Cooler flame temperature is responsible for a lower percentage conversion of fuel nitrogen content to $\mathrm{NO}_{\mathrm{x}}$. The uncontrolled $\mathrm{NO}_{\mathrm{x}}$ emissions are $25 \%$ lower from fluidized bed boilers. Further, operating temperatures of fluidized bed furnaces more 
closely match the temperatures for optimum $\mathrm{NH}_{3}$ and $\mathrm{NO}_{x}$ reaction. Control efficiency of $\mathrm{NH}_{3}$ injection for $\mathrm{NO}_{x}$ control is superior in fluidized bed boilers. Temperatures in fluidized bed boilers are more stable than in stoker grate boilers, which is also a benefit in $\mathrm{NO}_{\mathrm{x}}$ control. Lower flame temperatures result in less furnace slag formation and buildup on boiler surfaces.

\section{Chowchilla II Plant Flowsheet and Design Information}

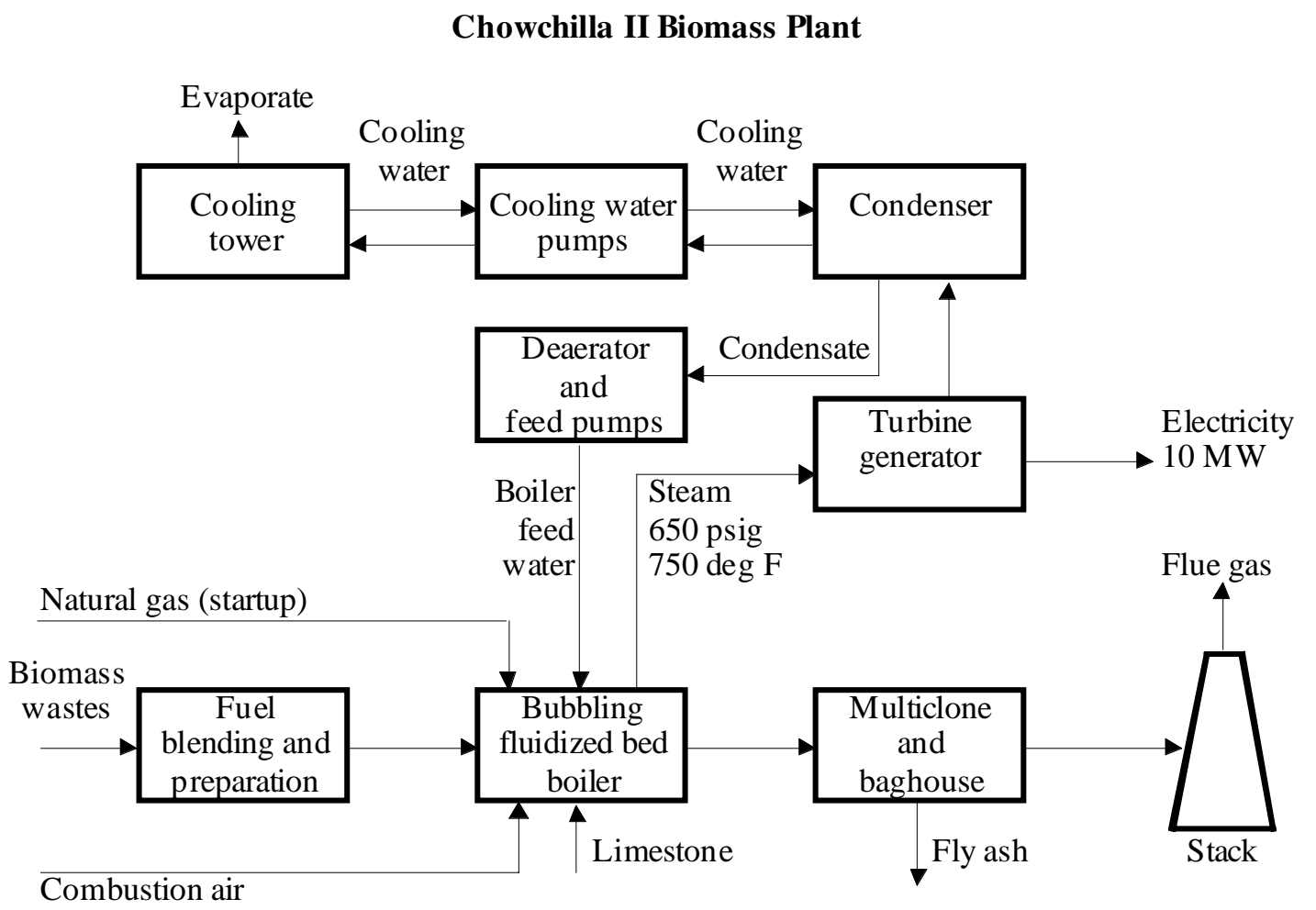

Boiler

- Atmospheric FBC (bubbling bed) provided by EPI.

- 700-hp ID fan.

- 600-hp FD fan.

- Two boiler feed pumps, one with $250 \mathrm{hp}$ motor, the other with Terry steam turbine driver.

- Forced circulation boiler

- 650 psig and $750^{\circ} \mathrm{F}$ main steam pressure and temperature.

- $130,000 \mathrm{lb} / \mathrm{h}$ main steam flow.

- $\quad 12 \mathrm{t} / \mathrm{h}$ maximum solid fuel feed rate.

Turbine/Generator

- General Electric turbine.

- General Electric generator (12.5 MW, 13,800 volts). 
Electrical

- Main transformer: $16,000 \mathrm{KVA}$.

- Main line voltage: 120,000 volts.

- Capacity loss adjustment factor: 0.989 .

Water

- Raw water supplied from onsite well with backup from city water system.

- Firewater system charged by city water system.

- Reverse osmosis and demineralization water treatment for boiler makeup capable of 12 gpm throughput.

- Cooling water 14,000 gpm circulation rate.

- Two cell evaporative cooling tower.

\section{Emissions Control}

- Multiclone separator and fabric filter baghouse for particulate control.

- Ammonia injection for $\mathrm{NO}_{\mathrm{x}}$ control.

- Limestone injection to fluidized bed for $\mathrm{SO}_{2}$ control.

- Ash utilized as soil amendment on local soils.

- Wastewater routed to onsite evaporation/percolation basins and used for onsite dust control, etc.

- Continuous emissions monitoring of criteria pollutants.

Plant Site

- Total site acreage: 14 acres (net).

- Perimeter fenced and key card gated access.

- Zoning: I 2, Heavy Industrial.

Permitting

- All permits active.

- No offset requirements.

\section{EI Nido Plant Flowsheet and Design Information}

Boiler

- Atmospheric FBC (bubbling bed) provided by EPI.

- 700-hp ID fan.

- 600-hp FD fan.

- Two boiler feed pumps, one with 250-hp motor, the other with Terry steam turbine driver.

- Forced circulation boiler

- $650 \mathrm{psig}$ and $750^{\circ} \mathrm{F}$ main steam pressure and temperature.

- $130,000 \mathrm{lb} / \mathrm{h}$ main steam flow.

- $12 \mathrm{t} / \mathrm{h}$ maximum solid fuel feed rate.

Turbine/Generator

- General Electric turbine.

- General Electric generator (12.5 MW, 13,800 volts). 
EI Nido Biomass Plant

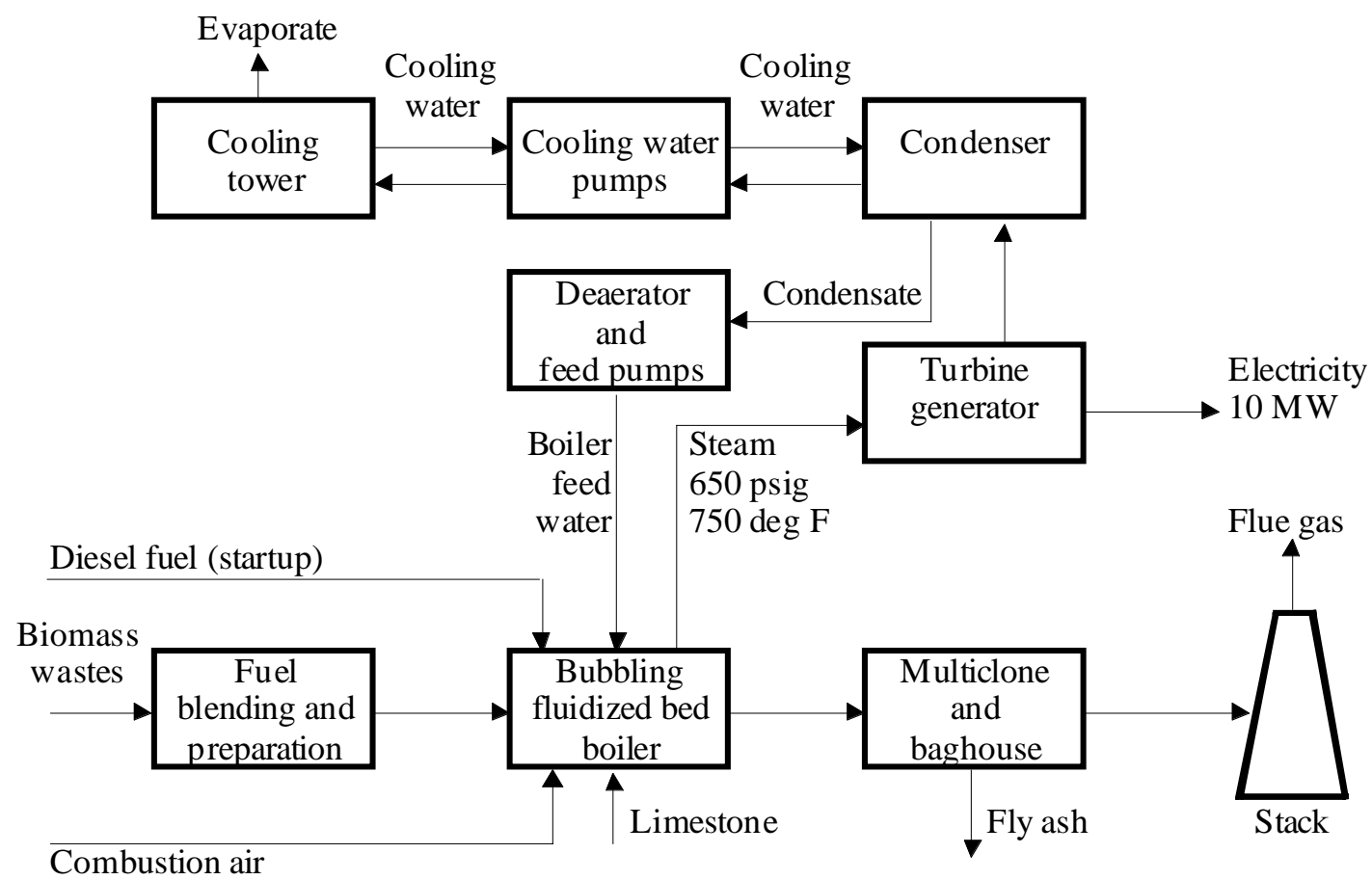

Electrical

- Main transformer: $16,000 \mathrm{KVA}$.

- Main line voltage: 72,500 volts.

- Capacity loss adjustment factor: 0.9741 .

Water

- Raw water supplied from onsite well.

- Firewater system charged by plant water system with backup diesel driven pump.

- Demineralization water treatment for boiler makeup capable of 200 gpm throughput.

- Cooling water 14,000 gpm circulation rate.

- Two cell evaporative cooling tower.

Emissions Control

- Multiclone separator and fabric filter baghouse for particulate control.

- Ammonia injection for $\mathrm{NO}_{x}$ control.

- Limestone injection to fluidized bed for $\mathrm{SO}_{2}$ control.

- Ash used as soil amendment on local soils.

- Wastewater routed to onsite evaporation/percolation basins and used for onsite dust control, etc.

- Continuous emissions monitoring of criteria pollutants. 
Plant Site

- Total site acreage: 76 acres.

- Perimeter fenced and key card gated access.

- Zoning: A 1, General Agricultural.

Permitting

- All permits active.

- No offset requirements.

\section{Madera Plant Flowsheet and Design Information}

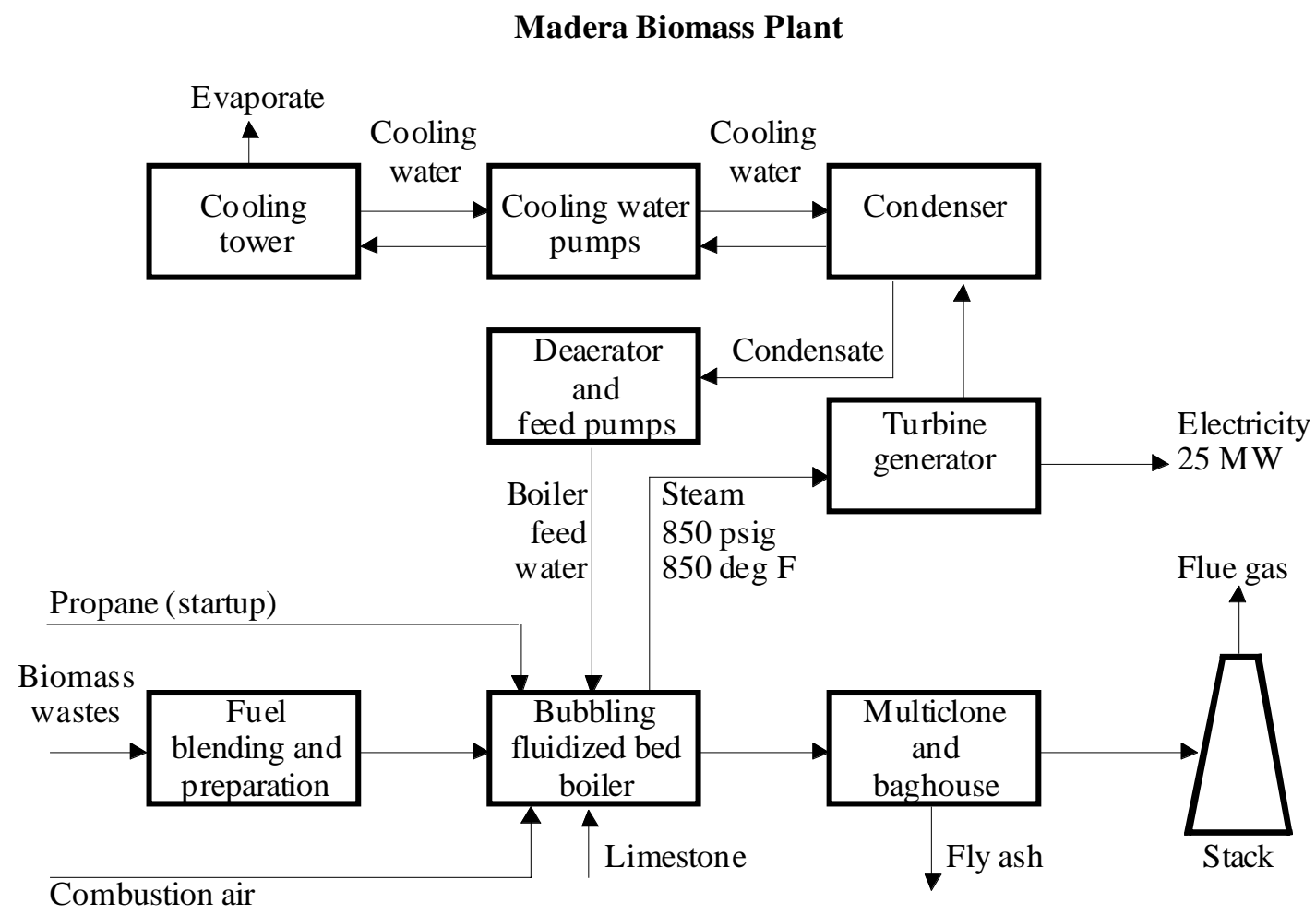

Boiler

- Atmospheric FBC (bubbling bed) provided by EPI.

- 1500-hp ID fan.

- 1750-hp FD fan.

- Two boiler feed pumps, one with 600-hp motor, the other with Terry steam turbine driver.

- Forced circulation boiler

- 850 psig and $850^{\circ} \mathrm{F}$ main steam pressure and temperature.

- $260,000 \mathrm{lb} / \mathrm{h}$ main steam flow.

- $28 \mathrm{t} / \mathrm{h}$ maximum solid fuel feed rate. 


\section{Turbine/Generator}

- Elliot turbine.

- Brush generator (28.5 MW, 13,800 volts).

Electrical

- Main transformer: 37,333 KVA.

- Main line voltage: 120,000 volts.

- Capacity loss adjustment factor: 0.989.

Water

- Raw water supplied from onsite well.

- Firewater system charged by plant water system with backup diesel driven pump.

- Reverse osmosis and demineralization water treatment for boiler makeup capable of 20 gpm throughput.

- Cooling water $16,000 \mathrm{gpm}$ circulation rate.

- Three cell evaporative cooling tower.

\section{Emissions Control}

- Multiclone separator and fabric filter baghouse for particulate control.

- Ammonia injection for $\mathrm{NO}_{x}$ control.

- Limestone injection to fluidized bed for $\mathrm{SO}_{2}$ control.

- Ash used as soil amendment on local soils.

- Wastewater routed to onsite evaporation/percolation basins and used for onsite dust control, etc.

- Continuous emissions monitoring of criteria pollutants.

Plant Site

- Total site acreage: 160 acres.

- Perimeter fenced and key card gated access.

- Zoning: ARE 40, Agricultural Rural Exclusive > 40 acres.

Permitting

- All permits active.

- Offset requirements: $25 \%$ of fuel to be offset fuel.

\section{Fuels}

Although most biomass plants in California concentrated on burning a high percentage of clean orchard or urban wood materials, the San Joaquin Valley Energy Partners experimented in combusting low-cost, low-demand agricultural waste materials such as grape pomace, green waste, onion and garlic skins, and bedding materials not desired by competing facilities. This operating philosophy resulted in changes to standard operating practices and alteration of the original plant design to successfully consume a much higher percentage of these low-cost materials. (Details were not made available.) 
NRG stated in its offering memorandum that this practice enabled the facilities to control and reduce average fuel costs below these of competing facilities and ensure a reliable supply during tight wood fuel market conditions. The owners were able to operate these plants with wide fuel flexibility, thus acquiring an economic advantage over the other biomass energy producers. (Interesting that the owners accepted a buyout offer if they had an economic advantage.)

Biomass materials that were successfully combusted fell into four categories:

- Agricultural wood: wood derived from whole orchard removal and orchard pruning harvested annually. Almond, nectarine, grape, orange, and olive prunings are examples of this category.

- Miscellaneous agricultural wastes: waste materials generated in processing agricultural produce such as olives, almonds, prunes, peaches, and many others. These materials include nut shells, grape and olive pomace, and stone fruit pits.

- Urban wood: derived from construction wood waste, demolition wood, tree prunings, and other wood wastes sorted from landfill materials generated by municipalities throughout California.

- Rangeland/forest wood waste: wood materials in the forms of logs, limbs, stumps, and brush that are not marketable for fiber or lumber products.

- Green wastes: urban tree trimmings, stumps, grass clippings, leaves, and any other plant material that has become a disposal liability to waste processors.

Fuels burned at the San Joaquin Valley Energy Partners facilities are listed below. The fuels in categories P1 through P3 are the primary fuels, which constituted more than 50\% of the plants' fuel. Secondary fuels (S1 through S4) made up 20\%-50\% of the total fuel, and tertiary fuels (T1 through T3) accounted for less than $20 \%$ of the total fuel to the plants.

\section{Operating Experience}

All three plants proved to be reliable. They demonstrated the ability to burn a wide variety of biomass fuels, including waste materials that other similar biomass plants avoided burning in significant quantities because of operating difficulties. To maintain high reliability, planned maintenance shutdowns were scheduled for 2 weeks during the spring and 1 week during the fall. Major repairs were done during these planned shutdowns to prevent emergency failures and outages. Typical outage repair work included refractory repair; boiler tube replacements and installation of shields; electric motor preventive maintenance work; fire side cleaning, baghouse cleaning and bag replacements; and bearing replacements, motor control center cleaning, and preventative maintenance inspections of all pumps, motors, gear boxes, fans, and other key components. The historical profiles of forced outages indicated an improving trend for reliability for all three plants. The facilities' operating histories are tabulated below, in terms of annual percent availability and percent $\mathrm{CF}$ (during peak and partial peak periods): 


\begin{tabular}{|c|c|}
\hline Almond prunings & $\mathrm{P} 1$ \\
\hline Apple prunings & $\mathrm{P} 1$ \\
\hline Apricot prunings & $\mathrm{P} 1$ \\
\hline Cherry prunings & $\mathrm{P} 1$ \\
\hline Citrus prunings & $\mathrm{P} 1$ \\
\hline Fig prunings & $\mathrm{P} 1$ \\
\hline Generic orchard prunings & $\mathrm{P} 1$ \\
\hline Grape prunings & $\mathrm{P} 1$ \\
\hline Nectarine prunings & $\mathrm{P} 1$ \\
\hline Olive prunings & $\mathrm{P} 1$ \\
\hline Peach prunings & $\mathrm{P} 1$ \\
\hline Pecan prunings & $\mathrm{P} 1$ \\
\hline Pistachio prunings & $\mathrm{P} 1$ \\
\hline Plum prunings & $\mathrm{P} 1$ \\
\hline Walnut prunings & P1 \\
\hline Cedar bark & $\mathrm{P} 2$ \\
\hline Forest slash/cull & $\mathrm{P} 2$ \\
\hline Hog fuel (mill residue) & $\mathrm{P} 2$ \\
\hline Sawdust & $\mathrm{P} 2$ \\
\hline Construction wood waste & P3 \\
\hline Demolition wood & P3 \\
\hline Landfill derived wood & P3 \\
\hline Landscape tree trimmings & P3 \\
\hline Pallet/bins wood & P3 \\
\hline Urban development clearing trees & P3 \\
\hline Grape pomace & $\mathrm{S} 1$ \\
\hline Olive pomace & $\mathrm{S} 1$ \\
\hline Raisin pomace & $\mathrm{S} 1$ \\
\hline Tomato pomace & $\mathrm{S} 1$ \\
\hline Cherry pits & $\mathrm{S} 2$ \\
\hline Nectarine pits & $\mathrm{S} 2$ \\
\hline Olive pits & $\mathrm{S} 2$ \\
\hline Peach pits & $\mathrm{S} 2$ \\
\hline Prune pits & $\mathrm{S} 2$ \\
\hline Almond shells & S3 \\
\hline Peanut shells & S3 \\
\hline Pecan shells & S3 \\
\hline Pistachio shells & S3 \\
\hline Walnut shells & S3 \\
\hline Cotton stalks & $\mathrm{S} 4$ \\
\hline Coffee grounds & $\mathrm{T} 1$ \\
\hline Cotton gin trash & $\mathrm{T} 1$ \\
\hline Turkey (wood) shavings & $\mathrm{T} 1$ \\
\hline Ditchbank or canal weeds & $\mathrm{T} 2$ \\
\hline Tumbleweeds & $\mathrm{T} 2$ \\
\hline Alfalfa straw & $\mathrm{T} 3$ \\
\hline Barley straw & $\mathrm{T} 3$ \\
\hline Bean straw/stalks & $\mathrm{T} 3$ \\
\hline Corn stalks & $\mathrm{T} 3$ \\
\hline Milo/sorghum & $\mathrm{T} 3$ \\
\hline Rice straw & $\mathrm{T} 3$ \\
\hline Wheat straw & $\mathrm{T} 3$ \\
\hline Char & $\mathrm{T} 3$ \\
\hline
\end{tabular}


Date commissioned

$\%$ Availability:

1992

1993

1994

1995 (Jan \& Feb only)

Project

$\% \mathrm{CF}$

(peak/partial peak periods):

1992

1993

1994

1995 (January and

February only)

Sustainable maximum

Sustainable minimum
Chow II

February 1990

$79 \%$

$84 \%$

$89 \%$

$99 \%$

$87 \%$

$94 \%$

$96 \%$

$98 \%$

$99 \%$

$97 \%$

$55 \%$
El Nido

October 1988

$87 \%$

$95 \%$

$94 \%$

$95 \%$

$87 \%$

$99 \%$

$96 \%$

$99 \%$

$93 \%$

$97 \%$

$55 \%$
Madera

July 1989

$83 \%$

$86 \%$

$90 \%$

$99 \%$

$87 \%$

$99 \%$

$98 \%$

$93 \%$

$99 \%$

$97 \%$

$55 \%$

The load-following capability, or dispatchability, of the bubbling fluidized bed units depends on the startup, ramp, and shutdown period requirements as shown below. The best load-following scenario for these facilities is operating the units at maximum load during peak/partial peak periods, then reducing to minimum load during off-peak periods. The generating units may be taken completely offline on weekends and holidays and started up for normal weekdays.

From cold shutdown to maximum load, $\mathrm{h}$

\begin{tabular}{|c|c|c|}
\hline$\underline{\text { Chow }}$ & $\underline{\text { El Nido }}$ & $\underline{\text { Madera }}$ \\
\hline II & & \\
\hline$\overline{12}$ & 12 & 12 \\
\hline 5 & 5 & 5 \\
\hline 1 & 1 & 1 \\
\hline 0.5 & 0.5 & 0.5 \\
\hline 2 & 2 & 2 \\
\hline 60 & 60 & 60 \\
\hline 10.8 & 10.8 & 24.6 \\
\hline 6 & 6 & 14 \\
\hline
\end{tabular}




\section{Environmental Performance}

The facilities' air quality permits were issued by the San Joaquin Valley Unified Air Pollution Control District. Continuous emissions monitoring equipment records the levels of $\mathrm{SO}_{2}, \mathrm{NO}_{\mathrm{x}}, \mathrm{CO}$, opacity, and $\mathrm{NH}_{3}$ emissions from the units. Permit and emission levels of the criteria pollutants at each plant are as follows, in $\mathrm{lb} / \mathrm{h}$ :

$\begin{array}{cccccc}\text { Chow II: Permitted } & \frac{\mathrm{SO}_{2}}{10 . \overline{4}} & \frac{\mathrm{NO}_{\mathrm{x}}}{10.4} & \frac{\mathrm{CO}}{22.9} & \frac{\mathrm{VOC}}{10.4} & \frac{\mathrm{PM}}{6.2} \\ \text { Actual } & 2.6 & 8.0 & 14.7 & 0.1 & 5.4 \\ & & & & & \\ \text { El Nido: Permitted } & 8.0 & 10.4 & 22.9 & 10.0 & 6.0 \\ \text { Actual } & 1.9 & 8.9 & 12.2 & 0.1 & 0.9 \\ & & & & & \\ \text { Madera: Permitted } & 29.0 & 50.0 & 60.0 & 24.0 & 10.0 \\ \text { Actual } & 0.5 & 16.0 & 30.0 & 0.3 & 6.5\end{array}$

The facilities' water permits are covered by the Waste Discharge Requirements (WDR) of the Regional Water Quality Control Board (RWQCB). The WDR allow for disposal of nondesignated wastewater into unlined ponds on the site. Plant systems are set up to allow all water to be disposed in this manner.

The facilities' solid wastes consist of ash (the noncombustible components of the biomass fuel) and spent bed material, including the limestone added for sulfur control. The ash is nonhazardous and is useful as a soil amendment. All the ash produced (100\%) is recycled to farms throughout the San Joaquin Valley as a beneficial soil additive. Routine sampling and analysis procedures ensure that the ash so distributed complies with all requirements for such use. This method of ash disposal is permitted under the WDR issued by the RWQCB.

\section{Economic Information}

Not provided. In general, fluidized bed boilers cost more than stoker grate boilers. Operating cost is also greater. Fluidized bed boilers cost more because of two additional boiler support systems, the preheat burner and the bed sand recycle system. Additional operating expense for fluidized bed boilers is a result of forced draft fan energy requirements and bed sand use.

A forced outage in a fluidized bed boiler is more costly than for a stoker grate boiler. Preheat expense and increased down time are increased cost factors for fluidized beds. Bed clinkering also requires replenishment of bed material, which can be expensive. 


\section{Lessons Learned}

Not provided. The primary lesson learned from the experience of the San Joaquin Valley Energy Partners was apparently that agricultural residues can be burned successfully in FBCs. However, the most difficult agricultural residues were assigned to the "tertiary" fuel category and mixed in small percentages with better fuels, primarily wood. All the primary fuels on the plants' fuel list are wood waste fuels, which constituted at least $50 \%$ of the total fuel. The secondary fuels consist of materials such as pomace, pits, shells, and stalks, and were kept in the range of $20 \%$ to $50 \%$ of the total fuel mix. The tertiary fuels are the notoriously difficult ones: straw, gin trash, weeds, etc. These fuels were kept below $20 \%$ of the total fuel mix.

\section{Sources and Contacts}

The information in this section was obtained from an offering memorandum dated May 1, 1997, posted on the NRG Energy, Inc. web site (www.nrgenergy.com). A telephone call to Mark Anderson of NRG (612-373-5350) on September 3, 1998 confirmed that the Chowchilla II, El Nido, and Madera plants were still for sale.

Contact information:

NRG Energy, Inc.

1221 Nicollet Mall, Suite 700

Minneapolis, MN 55403

Attn: Mark Anderson

Phone: 612-373-5350 


\section{BORALEX STRATTON ENERGY, STRATTON, MAINE}

The 45-MW Stratton Energy plant is the largest biomass-fired independent power project developed in Maine in response to PURPA regulations enacted by the state Public Utilities Commission. Originally developed by the ARS Stratton Group, the plant was bought in September 1998 by Boralex Inc., a Canadian company that owns a number of hydroelectric plants, three biomass plants, and one natural gas combined cycle plant. Central Maine Power Company (CMP) bought out its contract with the plant on July 28, 1998, and Boralex Stratton Energy now sells its power to Cinergy, a broker, under a 3-year contract. This new arrangement has allowed the plant to operate at full capacity; the CF from July 28, 1998 through December 31, 1998 was 100\%.

\begin{tabular}{|c|c|c|c|c|}
\hline \multicolumn{5}{|c|}{ Vital Statistics } \\
\hline \multirow{2}{*}{$\begin{array}{l}\text { Design capacity, net MWe } \\
\text { Configuration } \\
\text { Fuels }\end{array}$} & \multicolumn{4}{|c|}{$\begin{array}{c}45 \\
\text { Traveling grate stoker boiler }\end{array}$} \\
\hline & $\begin{array}{l}\text { Sawmil } \\
\text { Whole }\end{array}$ & $\begin{array}{l}\text { residues } \\
\text { ee chips }\end{array}$ & & $\begin{array}{l}\sim 75 \% \\
\sim 25 \% \\
\end{array}$ \\
\hline $\begin{array}{l}\text { Year } \\
\text { Net generation, MWh/year } \\
\text { Annual CF, \% }\end{array}$ & 1995 & $\begin{array}{c}1996 \\
305,000 \\
77.4 \\
\end{array}$ & $\begin{array}{c}1997 \\
305,000 \\
77.4 \\
\end{array}$ & $\begin{array}{c}1998 \\
353,000 \\
89.5 \\
\end{array}$ \\
\hline $\begin{array}{l}\text { Net heat rate, Btu/kWh } \\
\text { Thermal efficiency, HHV, \% }\end{array}$ & & & $\begin{array}{l}.500 \\
.3\end{array}$ & \\
\hline
\end{tabular}

\section{History and Outlook}

Central Maine Power Company, the largest electric utility company in the state, issued a series of requests for project proposals during the 1980s. The Stratton Energy plant was developed by the ARS Stratton Group. The project manager was HYDRA-CO Enterprises Inc., which was acquired by CMS Generation Company in 1995. The plant owner was then Stratton Energy Associates, a partnership of the ARS Stratton Group and CMS Generation Company. On July 28, 1998, CMP bought out the plant's PPA. On September 25, 1998, Boralex Inc., bought the plant from Stratton Energy Associates. Boralex Stratton Energy has a 3-year contract with Cinergy, who resells the power as a broker. On April 1, 1999, the Maine power market will be opened to wholesale customers, and in 2000, retail customers will be directly available to Boralex Stratton Energy. 
The in-service date was November 1989, and the first "power year" (November 1, 1989 through October 30, 1990) was the only year so far in which the plant did not deliver its full contracted amount of electricity to CMP. The original contract with CMP called for delivery of 295 million $\mathrm{kWh} / \mathrm{yr}$. In 1994 the amount was increased to 305 million $\mathrm{kWh} / \mathrm{yr}$. The contract was complicated, calling for some zero dispatch and $19.8 \mathrm{MW}$ output periods on weekends. Since July 28, 1998, when the CMP contract was bought out, the plant has run at $45 \mathrm{MW}(100 \% \mathrm{CF})$. Plant availability has been consistently in the $99 \%$ range.

The actual rated net capacity of the power plant is considerably higher than $39.8 \mathrm{MW}$, which was the contracted amount of capacity under the original contract with CMP. Twice each year NEPOOL runs a capability audit. Based on these audits, the Stratton Energy plant can deliver as much as $47.68 \mathrm{MW}$ of electricity to the grid. A nominal $45-\mathrm{MW}$ capacity has been used here to calculate CFs.

CMP Press Release, July 28, 1998

The following press release, issued by CMP on July 28, 1998, is instructive about the Stratton contract buyout, as well as the context in which it occurred:

AUGUSTA, Maine, July 28, 1998-As of today, Central Maine Power Co.'s purchases of electric energy from a non-utility power plant in Stratton are subject to a new arrangement with that will save the present-value equivalent of more than \$28 million for CMP and its customers.

The power-sales contract with CMP that was formerly held by Stratton Energy Associates has been transferred to an affiliate of Cinergy Capital \& Trading, a subsidiary of Cinergy Corp. of Cincinnati, Ohio. Meanwhile, the wood-fired power plant's owners have sold 100\% interest in the plant to Boralex, Inc., of Montreal, Canada.

Under new contractual arrangements, the 45-megawatt Stratton plant's output will be devoted to supplying CMP's needs through mid-2001; deliveries through 2009 could be provided by any resources available to Cinergy. The Stratton facility would operate as a "merchant plant" after 2001, competing freely in the electricity marketplace.

Necessary approvals were obtained from the Maine Public Utilities Commission and the Federal Energy Regulatory Commission. The FERC review included a new transmission interconnection agreement for the plant.

Like many other non-utility power contracts signed under state and federal energy policies of the 1980s, the Stratton contract provides energy at prices substantially above current market levels. CMP has bought out, legally terminated, or restructured 42 of these contracts since 1992, for savings estimated at \$258 million over the next five years. The indexed price-cap system administered by the Maine PUC provides for such savings to be shared between CMP and its customers during the annual price-cap adjustments. 
Maine's 1997 electric-competition law requires CMP to seek further economies in these contracts and other commitments. The aim is to reduce any "stranded-cost" transition charges that might appear on distribution customers' bills after retail competition starts on March 1, 2000 to continue recovery of previously authorized costs. (End of press release.)

In a different press release about a similar contract buyout, CMP stated that the average price of electricity across all of its nonutility power contracts was about $8.4 \phi / \mathrm{kWh}$, and stated that this was approximately twice the current (1998) wholesale electricity price in the state.

\section{Plant Flowsheet and Design Information}

\section{Boralex Stratton Energy Plant}

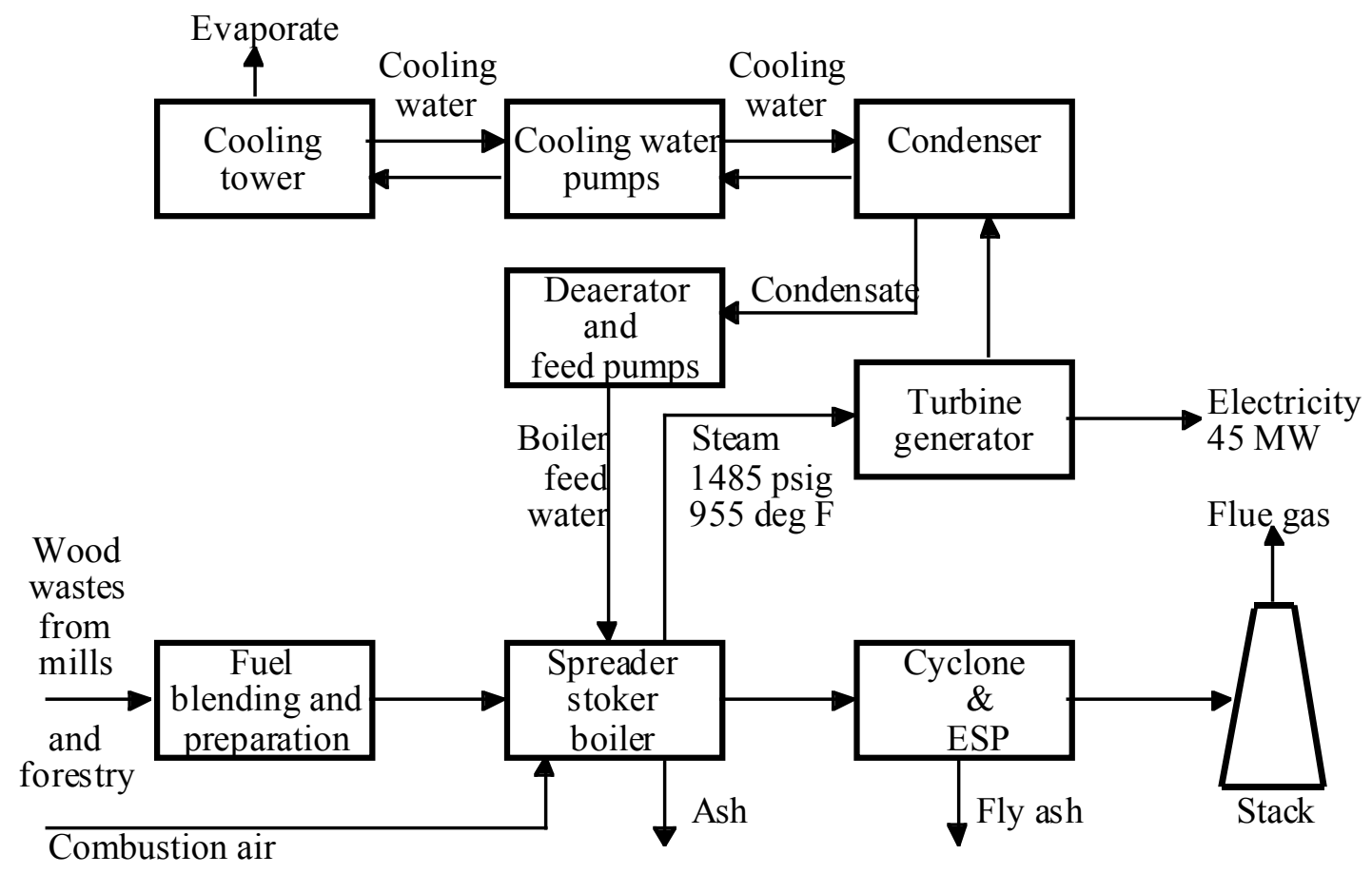

The plant has one traveling grate stoker boiler, provided by $\mathrm{ABB}-\mathrm{CE}$, that can produce $400,000 \mathrm{lb} / \mathrm{h}$ of $1485 \mathrm{psig}, 955^{\circ} \mathrm{F}$ steam. Mitsubishi provided the steam turbine and Brush provided the generator. Mechanical dust collectors and an ESP remove the PM from the stack gas. Staged combustion air is used to reduce $\mathrm{NO}_{\mathrm{x}}$ emissions to $0.18-0.20 \mathrm{lb} / \mathrm{Mbtu}$.

\section{Staffing}

In 1997, the plant had 33 employees. 


\section{Fuels}

Before July 28, 1998, the biomass fuel for the plant consisted of about $60 \%-70 \%$ sawmill residue (sawdust and bark), and about 30\%-40\% whole tree chips (which are mostly chips produced from unmarketable tops and limbs in forestry operations). The mill residues are considerably lower cost than the whole tree chips. Boralex has been able to increase the percentage of mill residues to about $75 \%$, which has reduced the overall fuel cost somewhat. Plenty of fuel is available in the area, but availability varies from season to season.

A variety of fuel purchasing arrangements are used: 5-, 3-, 2-, and 1-year contracts, plus some spot market purchases. Before the contract change, when the plant generated about 305,000 MWh/yr, the annual biomass use was about 464,000 t (as-received basis at nominally $50 \%$ moisture). Now that the plant is running at close to $100 \% \mathrm{CF}$, the fuel consumption rate is about 550,000 t/yr. The average net plant heat rate is about 13,500 $\mathrm{Btu} / \mathrm{kWh}$ (25.3\% thermal efficiency, HHV basis).

\section{Operating Experience}

The only area of the plant that required significant modifications after startup was the fuel yard. The original owners spent about $\$ 1.8$ million during the first year of operation to improve the operation of the fuel yard. Since that time the plant has operated reliably. Boralex Inc. has made no major changes in the plant equipment or operations since it took over in September 1998.

\section{Environmental Performance}

No mention was made of any difficulties in complying with the plant's environmental permit requirements. The plant is a zero discharge facility.

\section{Economic Information}

Statements by CMP imply that the original contract provided Stratton Energy an electricity price of about $8.5 \notin / \mathrm{kWh}$. The new contract provides a price that is less than half the old contract price - probably about $4 \varnothing / \mathrm{kWh}$. Because the plant has a new owner who agreed to the new power purchase contract, the operation is most likely profitable, or at least close to profitable, at this price level. In March 2000, the owner will be able to sell green power directly to retail customers, presumably at a premium over the current wholesale price.

\section{Lessons Learned}

The Stratton plant is a relatively large, efficient wood-fired plant with an excellent operating history. It appears to have a reasonable chance of surviving the transition from the regulated market of the 1980s with PURPA incentives to the competitive electric market of the 2000s. The plant managers in 1997 and 1999 did not identify any specific lessons learned, other than improvements to the fuel yard. 


\section{Sources and Contacts}

The primary sources of information on the Stratton Energy plant have been the plant managers_-Dan Noel in February 1997 and Jean Roy in February 1999.

Mr. Jean Roy

General Manager

Boralex Stratton Energy

Route 27 - P.O. Box 140

Stratton, ME 04982-0140

Phone: 207-246-2252, ext. $12 \quad$ Fax: 207-246-2257 


\section{TRACY BIOMASS PLANT, TRACY, CALIFORNIA}

The Tracy Biomass plant is an 18.5 MW (net) wood-fired plant that burns a little less than $50 \%$ orchard wood waste ("agricultural fuel") and a little more than 50\% urban wood waste. The agricultural fuel is required by the permit, which provides an offset from open burning emissions. The plant has a heat rate of 13,500-14,000 Btu/kWh. Plant availability has been high, and $\mathrm{CF}$ is more a function of contractual requirements than of availability.

\begin{tabular}{lc}
\multicolumn{1}{c}{ Vital Statistics } \\
\hline $\begin{array}{l}\text { Design capacity, net MWe } \\
\text { Configuration }\end{array}$ & 18.5 \\
& 1 water cooled vibrating grate stoker boiler \\
\hline Fuels & Agricultural residues (orchard removals \& prunings) \\
& Urban wood wastes \\
Net heat rate, Btu/kWh & $13,500-14,000$ \\
Thermal efficiency, HHV, $\% 24.4-25.3$ \\
Net generation, MWh/yr & $\sim 130,000$ \\
\hline
\end{tabular}

The plant is in a good location, near the intersection of major freeways I-580 and I-5 about $35 \mathrm{mi}$ east of Oakland. Highway 99, which runs through the heart of California's agricultural San Joaquin Valley, is about $15 \mathrm{mi}$ east of Tracy. One million acres of orchard land are both north and south of the plant, and the major landfills for the San Francisco Bay Area are in the vicinity (as is the Stanislaus County Waste-to-Energy plant). Thus the plant is well situated to receive agricultural and urban wood wastes.

\section{History and Outlook}

The plant came on line in 1990, and will receive "year 1-10" Interim Standard Offer \#4 (ISO4) payments for its electricity through 2000. Under a negotiated change in the contract, PG\&E has the right to curtail the plant's operation by up to $1000 \mathrm{~h} / \mathrm{yr}$, and does so. Tracy Biomass will pay off its construction loan by 2000 , and the challenge will be to operate "lean and mean" enough to stay in business after the CEC transition payments and the ISO4 year 1-10 payments expire.

Tracy Biomass is noted for a dedicated effort to inform and educate the local population about biomass and the advantages of biomass power. The public education is not formal program, but a varied collection of regularly practiced effective efforts. These efforts have included local and regional speaking engagements, use of local print media for timely story coverage, participation in Chamber of Commerce and Farm Bureau activities, sponsorship of local festivals, manning of booths at agricultural fairs, conducting tours for school 
children and teachers, and regular communication with local political representatives. As a part of its good neighbor policy and in recognition of a need, Tracy Biomass developed a yard waste program, in which local residents could dispose of clean wood wastes at very low cost. The material was blended into the plant's fuel mix. The onsite wood recycling center was closed in 1995 when the City of Tracy recycling center began operation.

\section{Plant Flowsheet and Design Information}

\section{Tracy Biomass Plant}

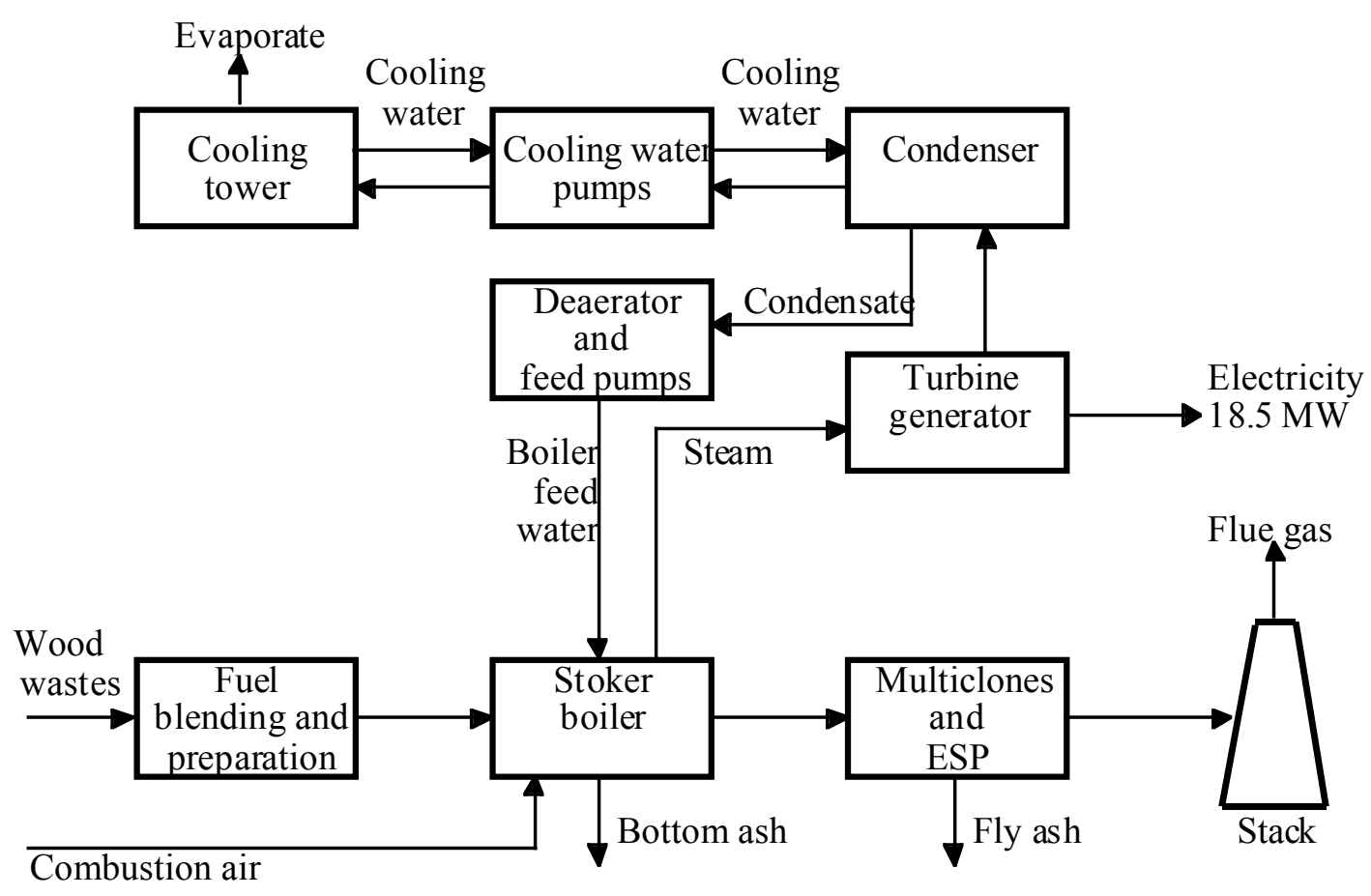

\section{Boiler}

The Babcock \& Wilcox stoker boiler has a Detroit Hydrograte water-cooled vibrating grate. (See the section on the Camas Cogeneration plant for a discussion of water-cooled vibrating grates.)

\section{Fuel System}

The plant weighmaster records all shipments and obtains a representative sample of each load, which is used for moisture analysis. The plant has two truck tippers and a typical fuel yard. Tracy Biomass keeps only about 2-3 weeks fuel inventory on hand. All the fuel passes through a screen before being conveyed to the boiler. Oversized particles are sent through a hog. 


\section{Emissions Control}

The plant has multiclone dust collectors and an ESP for particulate control. Ammonia is injected for $\mathrm{NO}_{x}$ control, and $\mathrm{NH}_{3}$ slippage causes a slightly visible plume. Fly ash is spread on farm fields and on cattle pens adjust $\mathrm{pH}$. Bottom ash is stored at the plant and is occasionally used as aggregate material in road building and similar applications. The plant obtains its water supply from deep wells on the property, and is a zero discharge facility with a cooling tower and an evaporator. The evaporator has been a source of problems for the operators.

\section{Staffing}

The total plant payroll is 21 people.

\section{Fuels}

During the early years of operation, Tracy Biomass built up an orchard wood waste service operation, including two large chippers, a fleet of trucks, and drivers. Workers were able to pull whole trees from the ground and feed them through a $\$ 400,000$ chipper, removing 5 to 10 acres of orchard trees per day. They provided excellent service to orchard owners, helping remove the wood waste from trees and prunings. This was during the high biomass fuel price era of 1990-1993.

When the ISO4 contract buyouts began in 1994-1995 and biomass fuel prices dropped, Tracy Biomass discontinued the orchard wood waste service. The prunings are much more expensive to collect than the whole trees harvested during orchard removals, because the yield is about 1 t/acre for prunings versus 20-30 t/acre for removals. Tracy Biomass mostly takes orchard removals as its agricultural fuel now. The cost of this fuel delivered to the plant is probably about $\$ 15-20 /$ dry $\mathrm{t}$.

All fuel is processed offsite by independent wood processing companies and delivered in clean form. The chips (agricultural fuel) flow easily through the plant feed equipment. The shredded or tub-ground fuel particles (the urban wood waste) cause more difficulties, sometimes hanging up and making birds' nests.

One of Tracy Biomass' main fuel suppliers is a fuel processing company in Livermore that charges tipping fees for wood wastes. The wood wastes probably come from throughout the East Bay Area. The distance from the processor to the Tracy Biomass plant is about 15 mil over the Altamont Pass. The plant pays about $\$ 5 / \mathrm{t}$ for the urban wood waste from the processor. The average moisture content is in the low $20 \%$ range.

The total fuel consumption by the Tracy Biomass plant is approximately 100,000-120,000 dry t/yr of waste wood (assuming 18.5 MW net output, a heat rate of 13,500-14,000 $\mathrm{Btu} / \mathrm{kWh}, 17 \mathrm{MBtu} / \mathrm{dry}$ t of wood, and 7,000-8,000 h of operation per year). Slightly less than half of the fuel is agricultural fuel; the remainder is urban wood waste.

\section{Operating Experience}

Operation has been mostly trouble free. There is enough chlorine in the fuel to have caused serious chloride corrosion of superheater tubes, which were replaced with stainless steel. 


\section{Environmental Performance}

Tracy is in a nonattainment area; thus, the permitting of any new facility requires some type of emission reduction or offset. Burning agricultural fuel (this prevents growers from burning in the field) provides the offset in the Tracy Biomass permit. The plant brochures and other public relations materials strongly emphasize the environmental benefits of collecting orchard wastes and burning them in the plant. However, the agricultural fuel is more expensive than the urban wood waste, and its use would be minimized if not for the permit requirement.

No mention was made of any difficulties in complying with the plant's environmental permit requirements.

\section{Economic Information}

Cost information was not disclosed, but a reasonable estimate of the cost of electricity is $5 \notin / \mathrm{kWh}$. As discussed earlier, fuel costs are approximately $\$ 6 /$ dry t for urban wood wastes and $\$ 15-\$ 20 /$ dry $t$ for agricultural fuel. The overall average is probably about $\$ 12 /$ dry $t$, which at $13,500-14,000 \mathrm{Btu} / \mathrm{kWh}$ is equivalent to about $1 \phi / \mathrm{kWh}$. The EPRI BIOPOWER model estimates O\&M costs for an $18.5-\mathrm{MW}$ wood-fired stoker plant to be $2 \notin / \mathrm{kWh}$. Annualized capital costs (construction loan payments), net of the $1.5 \phi / \mathrm{kWh}$ incentive payment provided by CEC, are probably about $2 \phi / \mathrm{kWh}$.

Tracy Biomass has indicated its intention to pay off its construction loan by the end of the 10-year "high-price" period on its ISO4 PPA. At that time (2000), the plant will have to begin selling power into California's competitive power exchange, and will still be eligible to receive as much as $1.5 \notin / \mathrm{kWh}$ in transition payments from CEC through 2001 . Once the transition payments are phased out, the cost of electricity from the Tracy Biomass plant will probably be about $3 \notin / \mathrm{kWh}$.

\section{Lessons Learned}

Tracy Biomass was not willing to share what it considered to be the most important lessons learned from 8 years of operating the facility. The plant operations and fuel managers are proud of the plant and its operating record. The numbers $(\mathrm{CF}$, heat rate, etc.) are excellent. There is a recognition that none of that would have been possible without the subsidy provided during the first 10 years of the ISO4 contract, and there is a real concern about the fate of the project after year 10 .

Lessons that can be inferred from the information about the Tracy Biomass project include:

- Urban wood waste can be a comparatively inexpensive fuel $(\sim 0.35 / \mathrm{MBtu})$ if the plant is located close to the urban area. Setting up a tipping fee fuel processing yard at the plant and reducing the cost of much of the urban wood waste fuel to $\$ 0 / \mathrm{MBtu}$ or less should be possible.

- Compared to urban wood waste, orchard wood is a relatively expensive fuel because growers are used to simply pushing and burning it, and are generally not willing to pay a fee to have the wood removed. Tracy Biomass spends approximately $\$ 1 / \mathrm{MBtu}$ for fuel from orchard removals. 


\section{Sources and Contacts}

Most of the information in this section was obtained during a plant tour conducted by Andy Carlin, fuel manager, and Brian Pillittere, plant operations superintendent, on July 16, 1998. Information was available from articles about Tracy Biomass in the Stanislaus Farm News and the Biomass Processors Association newsletter.

Brian K. Pillittere

Plant Operations Superintendent

Tracy Operators

P.O. Box 1209

Tracy, CA 95378-1209

Phone: 209-835-6914

Fax: 209-835-6918 


\section{CITY OF TACOMA STEAM PLANT NO. 2, TACOMA, WASHINGTON}

Tacoma Steam Plant No. 2 is a multifueled generating facility located on an urban site in the tideflats industrial area of Tacoma, Washington. The plant was originally built in 1931 and was repowered during the late 1980s with FBC to cofire wood, RDF, and coal. The repowered plant started commercial operation in August 1991. The plant is owned and operated by Tacoma Public Utilities, a municipal utility that provides water, electric, and rail service. On April 22, 1998 the Steam Plant was placed into reserve shutdown, and on June 15, 1988 the utility issued a request for qualifications for organizations to submit ideas and concepts about the possible acquisition or lease of Steam Plant No. 2 facilities and some adjacent properties.

Vital Statistics

\begin{tabular}{llrrr}
\hline Design capacity, net MWe & \multicolumn{4}{c}{$\sim$ 40 (see discussion below) } \\
& \multicolumn{4}{c}{ 2 bubbling FBC boilers } \\
& \multicolumn{1}{c}{1995} & 1996 & 1997 \\
\hline Fuels, \% by heat input: & Wood & 54 & 60 & 68 \\
& RDF & 14 & 20 & 20 \\
& Coal & 32 & 20 & 12 \\
Net heat rate, Btu/kWh & 17,252 & 19,955 & 24,426 \\
Thermal efficiency, HHV, \% & 19.8 & 17.1 & 14.0 \\
Net generation, $\mathrm{MWh} / \mathrm{yr}$ & & 91,688 & 94,083 & 88,488 \\
\hline
\end{tabular}

The Steam Plant's two turbine generators have a total rated capacity of $50 \mathrm{MW}_{\mathrm{e}}$ (gross). However, the capabilities of the combustion and ash removal systems constrain the plant's maximum output to 30-40 MW, depending on the fuel blend. In brief tests, the plant has operated at levels as high as $42 \mathrm{MW}$. During normal operations, the highest net output from the plant has been about 18.5 MW, running one combustor and one turbine/generator. The supply of RDF, the demand for power, and prices available in the secondary energy market have determined operating levels at the plant. During 1997 and 1998, the price of electric energy in the Tacoma market was generally less than $1 \varnothing / \mathrm{kWh}$. A biomass/waste-fueled plant cannot produce power at these low prices unless the fuels command substantial tipping fees. Steam Plant No. 2 operated only as much as necessary to burn the RDF it received-resulting in net generation rates of about 11-13 MW from 1994 to 1997 . The plant has burned, on average, about $60 \%$ wood, $20 \%$ RDF, and $20 \%$ coal. 


\section{History and Outlook}

Steam Plant No. 2 was originally built in 1931 as a 25-MW coal-fired steam-generating facility (later modified to burn oil and expanded to $50 \mathrm{MW}$ ) to supplement the area's hydroelectric power supply during low-water years. It was removed from service in 1973 because of problems with the superheaters and the capital expenditures necessary to bring the plant into full environmental compliance. At the time, it had logged less than 1 year of cumulative operation.

A feasibility study conducted in 1974 concluded that it would not be economical to refurbish the plant for continued peaking or baseload service. A 1979 plan to convert the facility into a cogeneration plant looked promising, but was halted because local industries would not commit to long-term steam contracts.

In 1984, EPI approached the City with a proposal to lease Steam Plant No. 2, refurbish and operate the facility, and sell power to Tacoma Power. Because of legal technicalities, the project could not be conducted with private ownership, but it looked attractive to Tacoma Power. After a feasibility study and several months of negotiations, the City took over the project in the spring of 1986.

In 1986, the City of Tacoma applied for and was awarded a $\$ 15$ million matching grant from the Washington State Department of Ecology. The grant was used both by Tacoma Power to repower Steam Plant No. 2 and by the local refuse utility to modify its resource recovery facility to produce RDF. Moorhead Machinery \& Boiler Company, a subsidiary of Westinghouse Electric Corporation, was selected to complete the design and construction. The total cost to the renovate Steam Plant No. 2 was approximately $\$ 45$ million.

Startup testing began in December 1989 and was running on all three fuels by April 1990 . Acceptance testing was performed starting in May 1990. Commercial operation began August 1, 1991. Power Magazine (April 1991), in awarding Steam Plant No. 2 its 1991 Powerplant Award, stated that "the major goal of the repowering project is to generate as much power as possible - or as dictated by electric demands-at the lowest cost, while combusting all of the city's 300 tons/day of refuse-derived fuel (RDF)." As it turned out, the amount of RDF delivered by the city's Refuse Utility and burned by Steam Plant No. 2 from 1993 through 1997 ranged from 28,539 to 48,412 t/yr, or about 78 to $133 \mathrm{t} / \mathrm{d}$.

Several design and mechanical problems were solved between 1991 and 1994, and a reliable mode of operation was established, which involved running one combustor at a time while the other was maintained on standby. From 1994 through 1997, net plant output was equivalent to about 11-13 MW, with an onstream factor of about $86 \%-87 \%$. Plant availability (to operate one combustor at a time and consume RDF) was maintained in the $90 \%-96 \%$ range. Initially, the cost of power from the plant was competitive within the utility's system, but dramatic drops in market prices for electricity made the plant uneconomical. Fuel costs decreased significantly in 1997, and a plan was developed to convert the plant to a tipping fee facility that would generate net revenues from most or all of its fuels. Implementation of this plan required modifications to the plant's air quality permit, which were underway when Tacoma Public Utilities put the plant on reserve shutdown in 1998. The future of the plant depends on the outcome of negotiations with the successful bidder, on the operating and business strategy pursued by the new owner, on 
alternative disposal options for Municipal Solid Waste, and on developments in electricity and fuel markets.

\section{Plant Flowsheet and Design Information}

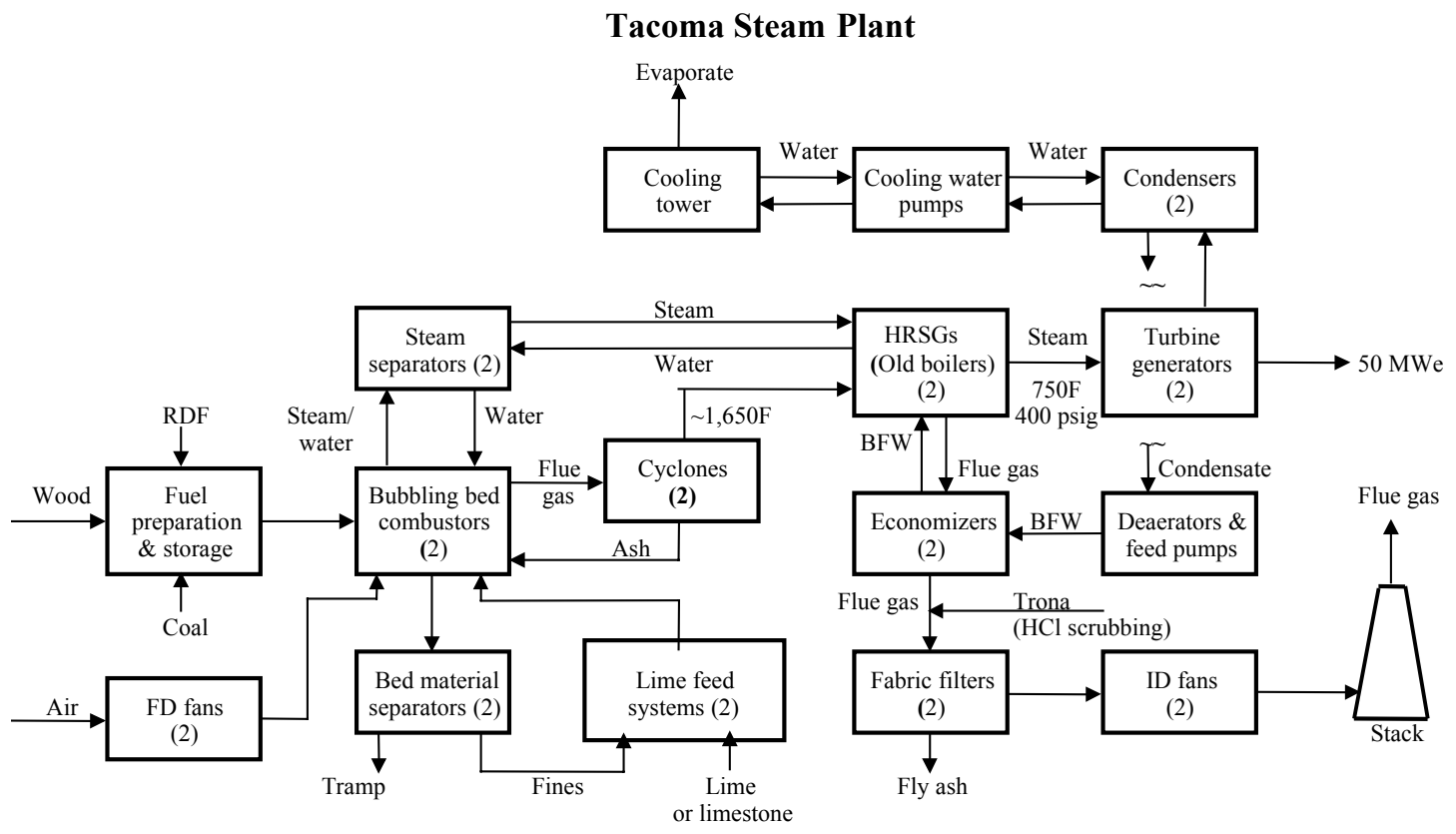

The repowering project consisted of installing two bubbling atmospheric FBCs, four refractory-lined cyclones that allow ash and unspent limestone to be reinjected into the combustors, and ductwork that connects the combustors to the boilers, which were converted to heat recovery steam generators (HRSGs). In addition, a mechanical draft cooling tower to replace salt water from the Hylebos waterway for steam condensing, fuel handling, pollution control and ash handling equipment, and a continuous emissions monitoring and computerized distributed control system were installed.

\section{Combustors}

The bubbling FBCs provided by EPI were designed to cofire a combination of wood waste, coal, and RDF. The design values were $15 \%$ RDF, 35\% wood, and $50 \%$ coal. The combustors can fire 0\%-100\% wood, 0\%-50\% coal, and 0\%-50\% RDF (permit limitation). The fuel mix is fed to the FBCs overbed and limestone is added directly to the beds for $\mathrm{SO}_{2}$ absorption. Bed temperatures are maintained at approximately $1550^{\circ} \mathrm{F}$ to minimize ash agglomeration and maximize sulfur capture. The combustors are designed for a total fuel input of $831 \mathrm{MBtu} / \mathrm{h}$, which corresponds (at full rated net output of $50 \mathrm{MW}$ ) to a net plant heat rate of about $16,620 \mathrm{Btu} / \mathrm{kWh}$. The permit limitation is $718 \mathrm{MBtu} / \mathrm{h}$. Combustion air is provided by $1500 \mathrm{hp} \mathrm{FD} \mathrm{fans} \mathrm{directly} \mathrm{to} \mathrm{the} \mathrm{fluidizing} \mathrm{air} \mathrm{manifold} \mathrm{of}$ each combustor, with no air preheat.

Refractory-lined cyclones (two per combustor) installed between the combustors and the HRSGs capture ash and unspent limestone for reinjection into the combustors. The refractory-lined cyclones are $18 \mathrm{ft}$ in diameter and capture PM larger than $30 \mu$. Reinjection 
ensures complete combustion, reduces the amount of fly ash to be removed downstream by the plant's fabric filters, and enhances limestone use. The reinjection system was disabled soon after startup because of excessive wear problems. As a result, lime has been used instead of limestone for $\mathrm{SO}_{2}$ control. (Lime is more expensive than limestone.)

The combustor operation most closely resembles a bubbling bed process, although the combustion air flow is great enough to carry some limestone and smaller unburned fuel particles from the combustion unit into the cyclone separators, somewhat like a circulating FBC process. The configuration of the combustors relative to the HRSGs gives at least $5 \mathrm{~s}$ of residence time for the flue gas at temperatures of approximately $1600^{\circ} \mathrm{F}$.

\section{Heat Recovery Steam Generators}

The boilers were converted to HRSGs by removing the burners and installing steam separation equipment, external superheaters, and economizers. Refractory ducting conveys the flue gas from the combustors through the cyclones to the waste heat boilers. The superheaters are mounted in the hot gas ductwork just ahead of the boiler fronts. This configuration allowed the superheaters to be shop fabricated and located in a very hot section of the flue gas stream (where the temperature is generally higher than $1650^{\circ} \mathrm{F}$ ). The superheaters employ bare, horizontal tubes with vertical headers, allowing full drainage of the units.

\section{Steam Generation}

In the forced circulation feedwater loop, water is taken from the front boiler drum by gravity flow to a new steam separator tank next to each combustor. Each tank provides suction for two 50\%-capacity pumps that circulate the water through the combustors' heat removal tubes. These tubes help maintain desired bed temperatures and evaporate approximately $60 \%$ of the feedwater.

The water/steam mixture from the combustors returns to the separator tanks where water is fed back to the circulation loop; steam continues to the front drum of the boiler. The steam is then directed through each boiler's rear drum and into the external superheaters. Final steam conditions are $750^{\circ} \mathrm{F}$ and $400 \mathrm{psig}$. Either combustor-boiler combination can supply steam to drive either steam turbine.

\section{Ash and Tramp Material Removal}

Fly ash is collected from the fabric filters and pneumatically conveyed to a silo that stores $900 \mathrm{t}$ or approximately $7 \mathrm{~d}$ of production at maximum generation levels. Ash is also collected from the hot cyclone separators, HRSGs, and economizers. The ash is discharged from the silo through a conditioner into trucks for transport.

Each FBC is equipped with a system to continuously remove undesirable (tramp) material from the bed media. The system allows bed media to flow from the cones making up the bottom section of each combustor (eight cones per combustor) through timed slide gates onto a divided vibrating pan conveyor. The vibrating pan conveyor is divided into two layers by a screen. As the bed media travels along the conveyor, the smaller particles pass through the screen and are transported to a bucket elevator for recycle into the combustor. The larger material that does not pass through the screen is composed primarily of glass, metal, rocks, and agglomerated bed media. 
Fuel System

Wood and RDF are delivered to a covered storage building by truck. These fuels are reclaimed from the storage building by ladder-type chain reclaimers and deposited on a dragchain conveyor. The conveyor deposits the wood/RDF mixture onto a belt conveyor for transfer to the fuel metering system. In addition, some wood is stockpiled in a nearby storage area. This area was designed as a full-scale ash demonstration project using fly ash and lime as a sub-base stabilizer for an asphalt application.

Wood fuel suppliers weigh in and out through an automated scale system and deposit their loads into a single truck dumper. The hog fuel passes over a disk screen and the overs that accumulate are resized by the Solid Waste Utility at no cost to the Steam Plant. The fuel is conveyed to one of five bays in the fuel building or deposits at an overflow bay at the end of the building. Normally, fresh wood is deposited at the overflow area and is stacked by loader on a current pile being built. The fuel handler also reclaims the wood and stages it under one of the reclaimers in the fuel house. Typically, Bays 4 and 5 are used for RDF.

A mix of wood and RDF is forwarded to the metering system on a belt conveyor. This mix passes under an electromagnet and over a magnetic head pulley to capture ferrous materials. The ratio of wood to RDF is established in the fuel house by gates over the dragchain that delivers fuel to the forwarding belt. The wood/RDF metering system was replaced with a totally redesigned auger system that can feed and meter a wide range of wood, RDF, and mixed fuels. This system can feed and meter almost any sized material smaller than 6 in., and has been successfully tested with coarser RDF in the wood-RDF mix. Key factors in the success of the wood/RDF metering system include:

- All stainless construction (except for AR flighting of augers)

- Negative slope bin with minimal surface discontinuities

- Large (28-in. outside diameter) augers with continuously varying pitch

- Large (20-in. square) discharge chutes

- Hydraulic drive for infinite control and full torque at low feed

Coal is delivered to the plant by self-unloading barges or trucks. The barges are moored in the Hylebos Waterway where they transfer their contents to a series of belt conveyors that place the coal in a storage pile. The coal is then moved from the storage pile by a wheel loader to a reclaimer that feeds a series of belt conveyors. The conveyors transport the coal into the day bunker in the boiler building where it is then forwarded to the combustor fuel metering system. The coal feed system was also replaced with auger feed equipment. The 10-in. standard AR augers are driven by 5-hp motors with a Woods inverter electronic drive. The turndown is limited by low-speed torque needs, but the fluidized bed system allows use of one, two, or three feeds as needed to achieve low-end performance.

\section{Emissions Control}

Granular limestone is injected into the FBCs to control $\mathrm{SO}_{2}$ emissions. The limestone handling system consists of a silo, where truck deliveries are accepted; a variable-speed dragchain conveyor that delivers the limestone to a flow splitter at the combustors; and a bucket conveyor that carries the limestone into the combustors. 
Two fabric filters, one for each flue gas exhaust train, control particulate emissions. Each baghouse has 1920 6-in. diameter by 14-ft long fiberglass bags. The filters are designed to remove $99.8 \%$ of the PM from the flue gas. Two 600-hp ID fans direct the two flue gas streams to a common 213-ft tall stack.

In 1997, an alkali sorbent injection system was installed upstream of the baghouses to remove trace amounts of hydrochloric acid $(\mathrm{HCl})$ from the flue gas. The scrubber uses trona (sodium sesquicarbonate) to react with the chlorine to form sodium chloride (table salt), which is removed along with the fly ash in the fabric filters. The chlorine originates primarily from plastics and other chlorine-containing materials in the RDF. Uncontrolled $\mathrm{HCl}$ emissions were typically about $260 \mathrm{PPM}$ in the flue gas; with lime and trona injection, $\mathrm{HCl}$ emissions drop to about $19 \mathrm{ppm}$. Overall $\mathrm{HCl}$ removal efficiency averages about $93 \%$.

\section{Plant Control}

The plant is controlled by a DCS supplied by Westinghouse Electric Corporation. Control is accomplished through the combination of local programmable logic controllers (PLCs) and direct connection of the DCS central computer to the process. All systems critical to the immediate operation of the plant are automated through the DCS and are under the control of the operator. Stand-alone systems such as ash handling are controlled by PLCs, with monitoring and limited operational control from the DCS.

\section{Staffing}

During plant operation, Steam Plant No. 2 is staffed with a crew of three, working 12-hour shifts per day. The crew consists of a control room operator, a roving auxiliary operator, and a fuel handler. Additionally, during normal business hours the plant is staffed with a manager, assistant manager, office assistant, relief control room operator, auxiliary operator and fuel handler, electrician, mechanic, and two engineers. The total staff on site during normal business hours is approximately 21 employees.

\section{Fuels}

As shown in the table on p. 82, the largest contributor to the fuel mix on a heat input basis has been waste wood (54\%-68\% from 1993 to1997). Coal, the most expensive fuel used, accounted for $27 \%-32 \%$ of the total from 1993 to 1995, but its use was reduced to $12 \%$ in 1997 as cost reduction became paramount. RDF, the zero-cost, "must-burn" fuel, accounted for 12\%-20\% of the total heat input to the plant from 1993 to 1997.

\section{Waste Wood}

From 1993 to 1996, all the waste wood for the plant was purchased on the spot market from about 100 authorized suppliers. About $64 \%$ of the wood fuel was from mill and logging sources, $23 \%$ from land clearing, and the remaining $13 \%$ from urban and industrial wastes. Moisture content was $22 \%-55 \%$. The annual average price paid by the plant for wood waste was \$0.72/Mbtu-\$0.88/MBtu from 1993 to 1996 . Wood waste prices tend to increase significantly during the winter.

Beginning in 1997 a concerted effort was made to obtain lower-cost wood fuel, resulting in an annual average price of $\$ 0.28 / \mathrm{MBtu}$. In 1997, approximately 65 active vendors supplied waste wood to the plant on a spot market or tipping fee basis. Storm debris in February 
and land clearing wood from May through October were obtained at zero or nearly zero cost. The reduction in the cost of wood and in the amount of coal burned (which cost more than $\$ 1.70 / \mathrm{MBtu}$ ), reduced the plant's fuel bill by more than $\$ 600,000$ from 1996 to 1997.

\section{RDF}

The City of Tacoma Refuse Utility delivers RDF at no cost to the Steam Plant. After sorted residential garbage reaches the Tacoma Resource Recovery Facility, it is shredded, air classified (separated by density), and mechanically separated. The mechanical separation steps include a drum magnet that separates ferrous metals, a primary disk screen that sends oversized material (ROF) through a secondary shredder back to the feed point, and sends undersized material (grit) to a secondary disk screen that discharges grit to be landfilled, and RDF to a compactor that feeds the compacted RDF to trucks that carry it to the Steam Plant. Ferrous metals are recycled; light plastics, paper, and wood are compacted into RDF.

\begin{tabular}{|c|c|c|c|c|c|}
\hline Year & 1993 & 1994 & 1995 & 1996 & 1997 \\
\hline \multicolumn{6}{|l|}{ Fuel burned, t/yr: } \\
\hline Wood & 175,806 & 118,511 & 87,949 & 118,997 & 162,900 \\
\hline RDF & 48,412 & 32,812 & 28,539 & 42,188 & 39,540 \\
\hline Coal & 39,563 & 33,262 & 25,539 & 19,373 & 13,295 \\
\hline \multicolumn{6}{|l|}{ Fuel HHV, Btu/lb: } \\
\hline Wood & 4,929 & 4,929 & 4,833 & 4,730 & 4,521 \\
\hline $\mathrm{RDF}$ & 4,546 & 3,918 & 3,886 & 4,556 & 5,361 \\
\hline Coal & 9,907 & 9,875 & 9,983 & 9,480 & 9.948 \\
\hline \multicolumn{6}{|l|}{ Fuel burned, MBtu/yr: } \\
\hline Wood & $1,733,096$ & $1,168,281$ & 850,115 & $1,125,712$ & $1,472,942$ \\
\hline $\mathrm{RDF}$ & 440,162 & 257,115 & 221,805 & 384,417 & 423,948 \\
\hline Coal & 783,901 & 656,925 & 509,912 & 367,312 & 264,517 \\
\hline Total & $2,957,159$ & $2,082,321$ & $1,581,832$ & $1,877,441$ & $2,161,407$ \\
\hline \multicolumn{6}{|l|}{ Fuel burned, $\%$ by heat: } \\
\hline Wood & 59 & 56 & 54 & 60 & 68 \\
\hline $\mathrm{RDF}$ & 15 & 12 & 14 & 20 & 20 \\
\hline Coal & 27 & 32 & 32 & 20 & 12 \\
\hline \multicolumn{6}{|l|}{ Fuel prices, $\$ / \mathrm{t}$ : } \\
\hline Wood & 8.52 & 8.68 & 7.00 & 7.19 & 2.53 \\
\hline RDF & 0.00 & 0.00 & 0.00 & 0.00 & 0.00 \\
\hline Coal & 35.61 & 33.88 & 33.50 & 34.03 & 34.42 \\
\hline \multicolumn{6}{|l|}{ Fuel cost, \$/yr: } \\
\hline Wood & $1,497,867$ & $1,028,675$ & 615,643 & 855,588 & 412,424 \\
\hline RDF & 0 & 0 & 0 & 0 & 0 \\
\hline Coal & $1,408,838$ & $1,126,917$ & 855,557 & 659,263 & 457,615 \\
\hline Total & 2.906 .706 & $2,155,592$ & $1,471,200$ & $1,514,852$ & 870,039 \\
\hline \multicolumn{6}{|l|}{ Fuel cost, \$/MBtu: } \\
\hline Wood & 0.86 & 0.88 & 0.72 & 0.76 & 0.28 \\
\hline RDF & 0.00 & 0.00 & 0.00 & 0.00 & 0.00 \\
\hline Coal & 1.80 & 1.72 & 1.68 & 1.79 & 1.73 \\
\hline Total & 0.98 & 1.04 & 0.93 & 0.81 & 0.40 \\
\hline Gross generation, $\mathrm{MWh} / \mathrm{yr}$ & 160,311 & 120,274 & 113,290 & 114,557 & 109,881 \\
\hline Net generation, MWh/yr & 130,253 & 97,091 & 91,688 & 94,083 & 88,488 \\
\hline Fuel cost, $\phi / \mathrm{kWh}$ & 2.2 & 2.2 & 1.6 & 1.6 & 1.0 \\
\hline Net heat rate, Btu/kWh & 22,703 & 21,447 & 17,252 & 19,955 & 24,426 \\
\hline Thermal efficiency, $\%$ & 15.0 & 15.9 & 19.8 & 17.1 & 14.0 \\
\hline
\end{tabular}


Any newspaper that is not separated at drop-off recycling sites becomes part of the RDF. A small portion of the city's yard waste ends up in the RDF as well, but most goes to a private topsoil firm for recycling. There is a separate drop-off center at the landfill for batteries, and crews on the tipping scales, tipping floor, and curbside are trained to separate out household batteries. The noncombustible portion of the garbage processed at the resource recovery facility is landfilled.

In a memorandum of understanding between the Solid Waste Utility and Tacoma Public Utilities, the Solid Waste Utility committed to producing and delivering to Steam Plant No. 2 , at its sole expense, 100-350 t/d of RDF conforming to the fuel specification in the agreement. Tacoma Public Utilities committed to receive, store, and incinerate the RDF at its sole expense. This arrangement is open to renegotiation for future owner/operators of Steam Plant No. 2. In 1997, Steam Plant No. 2 burned 39,540 t of RDF at an average rate of $125 \mathrm{t} / \mathrm{d}$. (Weekday deliveries averaged $150 \mathrm{t} / \mathrm{d}$.) The Solid Waste Utility has indicated that it would like to increase RDF production.

Combustion of RDF is currently limited to $30 \%$ by weight as stated in the Puget Sound Air Pollution Control Authority (PSAPCA) Notice of Construction issued January 27, 1998. This restriction allows the plant to operate as a cofired combustor and avoid compliance under the Municipal Waste Combustor rules (Subpart Cb of 40 CFR 60).

Coal

Obed coal from Oxbow Carbon \& Minerals, Inc., Canada, and Decker Coal from Kiewit Mining in Wyoming have generally been the lowest-cost coals available to the plant that met the PSD (air quality) permit requirement of less than $0.8 \%$ sulfur. The Obed coal is shipped by barge. The Decker coal is transported by rail to a nearby rail unloading facility, where it is transloaded onto trucks and delivered to the plant.

Natural Gas and Fuel Oil

Natural gas and fuel oil are used during startup. These fuels accounted for less than $1 \%$ of the total fuel consumption, and are not included in the fuel consumption figures shown in the table. Each combustor has two 50-MBtu/h above-bed gas burners that operate during startup until the flue gas temperature is raised sufficiently to allow the baghouse to be put into service. Each combustor also has a 10-MBtu/h distillate fuel oil burner located in the air supply plenum, which is used to heat the fluidized bed during startup.

\section{Opportunity Fuels}

The FBCs can burn a wide variety of fuels. Finding more opportunity fuels that command a tipping fee or can be obtained free became a high priority in 1997. The plant had received some wood for free, usually during winter and early spring as a result of major storms. Cities and counties paid the cost of collecting, processing, and delivering the storm debris to the plant, which was less expensive to them than landfilling. Analysis showed that by setting up a wood processing yard on site instead of buying prepared wood fuel from wood processors, the plant would be able to charge fees of about $\$ 15-\$ 25 / \mathrm{t}$ for stumps, tree wastes, and other wood wastes. The cost of grinding these materials on site would be about $\$ 5-\$ 15 /$ t. Wood processing yards in the area charge tipping fees for these types of wood wastes of $\$ 31-\$ 46 /$ t. 
In addition, the utility investigated the possible use of a variety of industrial wastes, such as asphalt roofing shingles (tear-offs), wood laminates, on/off-specification oil, oil sludges, oil-contaminated sorbents and rags, textile and plastic waste, green petroleum coke, nonrecyclable paper waste, and pulp mill clarifier solids that could generate revenues if they were acceptable fuels. Tipping fees for some of these items are \$80-100/t, and transport distances to facilities that accept them are longer than $100 \mathrm{mi}$. Burning some of these petroleum-based waste fuels might allow the plant to operate with no coal in its fuel mix. Technically, the bubbling FBCs and environmental control systems at the plant could probably handle any of these fuels. From 1997 to 1998, Tacoma Public Utilities acquired permits and developed a test burn plan for many of these fuels. The permits allow a 180-d period to burn the various fuels and conduct all necessary testing and monitoring to determine operational constraints required to assure compliance with current regulations. By eliminating coal and replacing most or all the purchased wood with tipping fee wastes, the plant's annual fuel cost, which in 1997 was still almost $\$ 870,000 / \mathrm{yr}$ or $1.0 \notin / \mathrm{kWh}$, could be converted to a net revenue stream of at least that amount, and possibly more.

\section{Operating Experience}

Significant improvements have been made to the fuel feed, combustion, and control systems since 1991. The plant has demonstrated successful operation on a wide variety of fuel mixes, including wood only, wood and RDF, coal and RDF, wood and coal, and varying combinations of all three fuels. Major factors that negatively affected power production and availability during early operations were:

- Shutdowns to remove wire from the combustors. Wire comes in the RDF and hangs up on the air manifolds, forming large nests that impede air flow in the combustor.

- A slagging condition in the combustor and cyclones that increases with increased firing rate and vapor temperatures.

- A fuel feed and metering system that delivered fuel to the combustor in an erratic manner. This fuel feed system was replaced in the fall of 1994.

- Insufficient heat transfer surface in the fluidized bed. More surface was added to increase the steam production capability.

Fuel consumption, electricity generation, and plant efficiency data from 1993 through 1997 are shown in the table on page 82. Basically, the plant was run at the rate needed to consume all the RDF delivered. From 1994 to 1997, the net generation was 88,000-97,000 $\mathrm{MWh} / \mathrm{yr}$, which is equivalent to production of 11-12 MW during the 7,500-7,700 $\mathrm{h} / \mathrm{yr}$ that the plant operated. About $12 \%-20 \%$ of the heat input was provided by the RDF, and the remainder by wood and coal, as required by the plant's air quality permit conditions and operating considerations.

Usually, one FBC unit operated while the other received maintenance or sat in standby condition. After 2-3 months of operation, the operating unit was shut down for inspection and maintenance and the other unit was started up. In 1997, for example, unit 1 operated $4127 \mathrm{~h}$ and unit 2 operated $3535 \mathrm{~h}$, giving a total plant operating time of $7662 \mathrm{~h}$, or $87.5 \%$ of the $8760 \mathrm{~h}$ that year. Plant availability (operating one combustor at a time, to consume RDF) was $95.8 \%$ in $1995,92.4 \%$ in 1996 , and $93.4 \%$ in 1997. 
Because of the plant's unique (retrofitted) design and low steam temperature and pressure, the thermal efficiency of Steam Plant No. 2 is relatively low. As the table on page 82 shows, the net plant heat rate increased from $17,252 \mathrm{Btu} / \mathrm{kWh}$ in 1995 to $24,426 \mathrm{Btu} / \mathrm{kWh}$ in 1997 as the percentage of coal in the fuel mix decreased from $32 \%$ to $12 \%$ by heat input. The heat rate would improve if the plant were run closer to its design output. If the development of an on-site fuel processing capability produced a net revenue stream from tipping fee fuels, improving the plant's thermal efficiency would not be an important consideration.

The auxiliary power requirements of Steam Plant No. 2 (the difference between gross and net generation) are also relatively high, at about $18 \%-20 \%$ of the gross $\mathrm{MWh} / \mathrm{yr}$. This is also explained by the unique plant design and by the low $\mathrm{CF}$ at which the plant has operated.

\section{Environmental Performance}

Steam Plant No. 2 has met or operated significantly below all required state, federal, and local air emission requirements. Fluidized bed combustion with limestone injection results in very low $\mathrm{SO}_{2}$ and $\mathrm{NO}_{x}$ emissions. The fabric filters remove $99.8 \%$ of the $\mathrm{PM}$ from the flue gas stream. A continuous emissions monitoring system measures $\mathrm{SO}_{2}, \mathrm{NO}_{x}, \mathrm{CO}$, and $\mathrm{O}_{2}$ levels in the exiting flue gas. Opacity is measured and roughly indicates particulate concentration. In 1997 an alkali sorbent injection system was added upstream of the baghouses to remove $\mathrm{HCl}$ from the flue gas. Operation of this unit has been successful, with greater than $90 \% \mathrm{HCl}$ removal.

The permitted emissions, with the control method used, are as follows:

- $\mathrm{SO}_{2}-0.18 \mathrm{lb} / \mathrm{MBtu} 30-\mathrm{d}$ rolling average or at least $70 \%$ control. Control—Lime or limestone injection and the use of a low $(0.8 \%$ or less) sulfur coal.

- $\mathrm{NO}_{\mathrm{x}}-0.50 \mathrm{lb} / \mathrm{MBtu}$ (hourly average). Control-Maintain temperature in combustion zone at $1450-1550^{\circ} \mathrm{F}$.

- $\mathrm{CO}-0.52 \mathrm{lb} / \mathrm{MBtu}$ or $425 \mathrm{ppm}$ (hourly average). Control-Proper combustion control, 5-s residence time.

- Opacity-10\% for an aggregate of more than $3 \mathrm{~min}$ in any 60 -min period; $5 \%$ hourly average. Control-Baghouse.

- Particulate matter-0.010 gr/sdcf of flue gas, corrected to $7 \% \mathrm{O}_{2}$ total catch, 0.0068 $\mathrm{gr} / \mathrm{dscf}$ front half catch (first test indicates 0.004 gdscf actual). Control-Baghouse with Ryton filter bags.

Nearly all the plant's generation by-products (fly ash, aggregate, and tramp residues) are recycled. An extensive 3-year ash testing program culminated in April 1994 when Tacoma received a Certificate of Designation from the Washington State Department of Ecology certifying Steam Plant No. 2 fly ash as a solid waste under federal and Washington State laws. Most of the ash is used for waste stabilization of oily sludges; some is sent to a cement manufacturing facility in Seattle where it displaces clay in the cement manufacturing process. Some is being used as a soil amendment in mine reclamation efforts. The tramp, or bottom ash material, is separated and the aggregate portion used as a road base material. The metals are sold to a recycling facility and the remaining tramp, consisting mostly of glass, wire, plastic, and clinkers, is then landfilled. 
During the last 5 years of operation, the ash generated has averaged 14,000 t/yr. More than 98\% of the ash generated in 1997 was supplied to users at an average cost to the utility of about \$3/t. During 1997, 242 were landfilled at a cost of about \$36/t.

\section{Economic Information}

The total cost to renovate Steam Plant No. 2 was approximately $\$ 45$ million, partially funded by a $\$ 15$ million grant from the Washington State Department of Ecology. In 1993 , the variable cost of power from the plant averaged about $4 \varnothing / \mathrm{kWh}, 2.2 \phi$ of which were fuel costs. At that time, this $4 \phi / \mathrm{kWh}$ cost was lower than the costs of power from other potential resources that were being considered for development by Tacoma Public Utilities. It also favorably offset the purchase of outside power from the Bonneville Power Administration. The situation had changed by 1996-1997, however. Although the plant's fuel cost had been reduced to $1.6 \varnothing / \mathrm{kWh}$ in 1996 and $1.1 \varnothing / \mathrm{kWh}$ in 1997 (annual averages), and the variable cost of power from the plant was in the $1.5-3 \phi / \mathrm{kWh}$ range, the energy market in the Pacific Northwest had dropped to about $0.5 \varnothing / \mathrm{kWh}$ (off peak) and 0.7 $0.8 \notin / \mathrm{kWh}$ (on peak).

In early 1998 Tacoma Public Utilities was operating Steam Plant No. 2 at an estimated loss of about $\$ 3$ million/yr. The Solid Waste Utility was benefiting from the combustion of RDF by about $\$ 1$ million/yr, so the city-wide loss was about $\$ 2$ million/yr. Work was proceeding on the modification of the plant permits to allow onsite processing and combustion of tipping fee fuels, which would allow the plant to eliminate the loss at some point in the future. In April 1998, Tacoma Public Utilities put the plant up for sale.

\section{Lessons Learned}

Plant personnel suggested the following lessons learned from their experience at Tacoma Steam Plant No. 2:

Fuel

- Fuel, fuel, fuel to a biomass/waste fueled power plant is like location, location, location to a realtor. Don't box the facility in with a limited fuel supply and/or permit. The more options the better.

- Fuel procurement should be one of the highest priorities and a full-time job.

- Obtain a low-cost fuel supply in sufficient quantities to maximize generation.

- Focus on fuel cost $(\phi / \mathrm{kWh})$ rather than fuels that provide highest efficiency (Btu/kWh) saved the plant $\$ 600,000 / y r$ in coal costs. Opportunity fuels (with tipping fees) have the potential to eliminate fuel costs and generate net revenues.

- Carefully evaluate the real costs of zero cost or tipping fee fuels. There are always costs associated with fuel preparation and combustion that the plant must absorb.

- RDF fuel quality - elimination of aluminum and copper wire from RDF would make this a more acceptable fuel. These elements significantly contribute to bed fouling and slagging, which cause frequent plant shutdowns. The elemental aluminum in the fly ash decreases its marketability. If the RDF were denser, the plant efficiency would improve because of combustion in the bed rather than in the vapor space. Acid gases from chlorine in the RDF require additional sorbent expense and an injection system. 
Fuel Feed System

- Take extra care at the beginning of the project with design of the fuel feed system. Go with a proven fuel feed system; don't let someone sell you an unproven feed system.

- Make certain that fuel quantity can be accurately measured. Because wood and RDF are transported to the combustor on one conveyor and commingled, Tacoma cannot accurately measure the quantity of each delivered to the combustor. These measurements are of obvious importance in recording heat rate and economics. Redundancy and overall control of the process is sacrificed.

Plant Design

- Fuel flexibility - when developing combustor design and environmental permits for a new plant, this should be one of the highest priorities. A CFB or increased height on the combustors would have been more appropriate to eliminate slagging problems.

- Design the plant for worst-case scenario fuels and for easy clean out. The Tacoma plant needs a sand storage system that cleans, stores, and transports bed media during the combustion cleanup process with minimum manpower.

- Expect fouling (especially with RDF in the fuel mix). Design the facility for easy cleanup and perhaps with on line cleaning ability to minimize down time. A preventative maintenance program is essential.

Operation

- Develop and follow standard operating procedures that eliminate operator variables and give more consistency in operations. This avoids seesaw operations that shorten run time. It also helps identify problems quickly. If the procedure is not working it can be more easily identified and corrected.

- Multitasking of labor - train and assign personnel to do more than one job.

- Focus on preventative maintenance to reduce operating costs.

Ash Marketing

- Ash marketing/sales rather than disposal saved the plant $\$ 600,000 / y$ r.

- Design the ash handling system to optimize ash as a product. That might mean that the ash system drops out and stores ash at different locations for different applications and better marketability.

- Research ash markets and determine just what the plant will be producing with each anticipated fuel mix combination; then market it. Landfilling ash should be the last resort. 


\section{Sources and Contacts}

Much of the descriptive information in this report section was obtained from the following published sources:

- $\quad$ Power Magazine, April 1991. "Bubbling Bed Combustors Achieve True Cofiring of RDF, Wood, Coal."

- Independent Energy (reprint not dated). "Fluidized Bed for Resource Recovery," by Patrick McCarty, P.E., Tacoma City Light and Thair Jorgenson, P.E., Tacoma Refuse Utility.

- Proceedings: Strategic Benefits of Biomass and Waste Fuels. Electric Power Research Institute (EPRI) TR-103146, December 1993. "RDF/Wood/Coal Cofiring at Tacoma City Light Steam Plant No. 2," by Mark B. Gamble.

- Request for Qualifications for Steam Plant No. 2 Business Opportunities, Tacoma Public Utilities, June 15, 1998.

Mark Gamble was the Steam Plant manager from startup through September 1997, when he left to become plant manager of a large fluidized bed project in Thailand. Laurie Hannan was assistant plant manager until September 1997, when she was promoted to plant manager. Dan Rottler, P.E., was plant engineer since February 1995. These people were very generous with their time, and helpful in providing information and reviewing this report section.

Contact information:

Tacoma Public Utilities

Steam Plant No. 2

1171 Taylor Way

P.O. Box 11007

Tacoma, WA 98411-0007

Laurie Hannan, Plant Manager phone: 253-502-8601

e-mail: lhannan@ci.tacoma.wa.us

Dan Rottler, P.E., Mechanical Engineer

phone: 253-502-8605

e-mail: drottler@ci.tacoma.wa.us

Fax 253-502-8607 


\section{COLMAC ENERGY, MECCA, CALIFORNIA}

Colmac Energy operates a 49-MW wood-fired power plant in Mecca, California (southeast of Palm Springs in Riverside County). The plant has two circulating FBC boilers. The permit conditions, established and monitored by the South Coast Air Quality Management Board, are among the most stringent of any biomass power plant in the United States. The plant runs very well and has operated at a net plant heat rate as low as 12,200 Btu/kWh (thermal efficiency of $28.0 \%$, HHV basis). The annual CF from 1995 to 1998 was 85\%$92 \%$.

Vital Statistics

\begin{tabular}{|c|c|c|c|c|}
\hline $\begin{array}{l}\text { Design capacity, net MWe } \\
\text { Configuration }\end{array}$ & \multicolumn{4}{|c|}{$\begin{array}{r}\sim 49 \text { (see discussion below) } \\
2 \text { circulating FBC boilers }\end{array}$} \\
\hline Fuels: & \multicolumn{4}{|c|}{$\begin{array}{l}\text { Urban wood wastes } \\
\text { Agricultural wood wastes } \\
\text { Petroleum coke }\end{array}$} \\
\hline $\begin{array}{l}\text { Year } \\
\text { Net generation, MWh/year } \\
\text { Annual CF, \% }\end{array}$ & $\begin{array}{c}1995 \\
368,000 \\
85.8 \\
\end{array}$ & $\begin{array}{c}1996 \\
395,000 \\
92.1 \\
\end{array}$ & $\begin{array}{c}1997 \\
382,000 \\
89.0 \\
\end{array}$ & $\begin{array}{c}1998 * \\
393,000 \\
91.6 \\
\end{array}$ \\
\hline $\begin{array}{l}\text { Net heat rate, Btu/kWh } \\
\text { Thermal efficiency, HHV, \% }\end{array}$ & \multicolumn{4}{|c|}{$\begin{array}{c}12,400-12,200 \\
27.5-28.0 \\
\end{array}$} \\
\hline
\end{tabular}

*Projected in August 1998.

Early documentation on the plant describes it as a 47-MW (net) facility. A Power Magazine article (April 1992) says the turbine/generator is a nominal $47 \mathrm{MW}$ unit. The plant manager says the net capacity is $49 \mathrm{MW}$. A Colmac Energy brochure advertising mobile grinding services describes the plant as a 49.9-MW facility.

\section{History and Outlook}

Colmac Energy is a privately owned subsidiary of Access Capital International. The plant is located at the southern end of the Coachella Valley, on land leased from the Cabazon band of Mission Indians in Riverside County. This is an arid region with mean monthly temperatures of $31^{\circ}-107^{\circ} \mathrm{F}$ and annual rainfalls of only 2.8 in. Phillip Reese of ReeseChambers Systems Consultants, Inc. (which permitted the development of 13 of the California biomass plants) served as manager of project development and environmental coordinator, and is now a director of Colmac Energy. Walsh Construction built the plant under an engineering procurement contract with Colmac Energy. Following a 6-year design, development, and permitting process, Colmac Energy started up in October 1991, and entered full commercial operation in February 1992. Southern California Edison buys 
$45 \mathrm{MW}$ of capacity and energy under an ISO4 contract. The 10-year high-priced period runs until February 2002. Colmac is the newest of the ISO4 biomass plants in California.

\section{Contract Buyout}

On February 1, 1999, the following article appeared in "California Energy Markets:"

Southern California Edison recently filed an application for termination of a power purchase contract with the 45 MW Colmac Energy biomass plant, near Mecca in the Imperial Valley [A98-12-038]. Edison will pay Colmac $\$ 127$ million to terminate the contract, claiming the deal will result in ratepayer savings of between \$30.9 million and \$58.8 million (net present value) compared to contract prices.

The QF plant, which has been in operation since 1992, carries a 30-year Standard Offer No. 4 contract that pays the independent producer \$198/KW-yr for capacity and forecasted avoided-cost rates for energy deliveries during the first ten years of operations. The 1998 energy price was listed at $\$ 0.146 / \mathrm{KWh}$ and would rise to $\$ 0.156 / \mathrm{KWh}$ by the end of tenth year--in February 2002--before falling to Edison's short-run avoided cost (SRAC) rate for the remaining 20 years of the contract. By that time, however, SRAC is expected to revert to the Power Exchange clearing price. The unit also is eligible for capacity bonus payments if it exceeds a CF of 85 percent during certain peak demand periods.

The Colmac unit has a long regulatory history. The SO4 contract was originally signed in 1985 with the expectation of starting operations in 1987, but Colmac later wanted to move the unit's location to land owned by the Cabazon Indian Tribe and to defer its start-date. Though the utility did not want to do that, Colmac won a 1989 California Public Utilities Commission decision ordering Edison to accept the site change and deferral [D89-04081].

After some operational problems during start-up, the facility managed an average CF of 85.5 percent. During 1995 the owner performed major modifications to components of the combustion system and there was an extended outage in April 1998 that required operators to install new boiler equipment. According to the filing, the unit has achieved "record production" since. During 1996 and 1997 the Colmac plant generated more than $350 \mathrm{GWh}$ of energy each year.

An independent consultant hired by Edison to verify the project's viability in order to qualify for a contract restructuring concluded that the plant is currently viable. It may be expected to continue operations for the duration of its contract and is able to obtain economic and abundant fuel supplies for the rest of its planned operating life, according to the consultant. 
Greg Lawyer, president of Colmac Energy, declined to offer specifics of the deal, citing a confidentiality agreement with Edison. He did say, however, that the arrangement includes a restart provision allowing the utility to call the plant into service within two years. "After that we're free to do what we want," Lawyer said.

Possibilities include repowering the facility, selling into the competitive marketplace--as is being done by former QF Burney biomass (see CEM No. 490 [22])--or perhaps rededicating the plant to another use. Lawyer noted that the Cabazon Indian Tribe operates a tire recycling facility right next to Colmac. Using the circulating fluidized-bed combustion technology already in place at Colmac might be a good fit for tire burning, he suggested. "It all depends on driving costs down to be competitive," he said.

Edison asked for CPUC approval without hearings. Though the application was initially filed December 23, 1998 at the CPUC's Los Angeles office, evidently it was lost in transit to San Francisco along with a large bundle of other mail. Copies of the filing did not appear until January 12, but the CPUC allowed the application to be logged as of the December date.

\section{Urban Wood Waste Utilization}

The Colmac plant is one of only three biomass plants in Southern California drawing fuel from the greater Los Angeles basin area. (One of these plants is currently shut down.) The Colmac plant is by far the largest combustor of urban wood wastes in the state, using 1000-1200 t/d (including moisture content) of fuel, of which $80 \%-90 \%$ would otherwise be landfilled. The remainder of the plant fuel consists of agricultural residues, primarily from citrus and date orchard prunings and removals.

By virtue of its urban fuel consumption, the Colmac plant is a major factor in Riverside County's ability to comply with the mandatory landfill diversion and waste reduction requirements of California's recycling law (AB 939). The recovery of energy from biomass has been allowed as recycling credit by the state Integrated Waste Management Board.

Collection of orchard residues for use as fuel by the plant has almost completely eliminated open field burning in the Coachella Valley. The Coachella Valley is also the location of Palm Springs, Rancho Mirage, Indian Wells, La Quinta, and other desert resort cities that depend on clear desert air for tourist attraction.

The plant staff has made some good progress in obtaining lower fuel prices as the supply infrastructure has matured and wood waste processors have started to charge tipping fees. The plant's air quality permit was modified to allow the combustion of petroleum coke, which can be a very inexpensive fuel at times. The financing bank wants the loan paid off, and Colmac plans to do that before the end of the first 10 years of the contract. Colmac has invested in equipment that should eventually reduce O\&M costs. But, Phillip Reese wrote in 1995: "will the Colmac plant be able to compete if California decides that low price electricity is the only measure of the worth of a generating station? I doubt it." 


\section{Plant Flowsheet and Design Information}

\section{Boilers}

The plant has two ABB circulating FBC boilers. The boilers have a combined output of $464,000 \mathrm{lb} / \mathrm{h}$ of superheated steam at $1255 \mathrm{psig}$ and $925^{\circ} \mathrm{F}$. Fuel is discharged from a day bin atop the boilers via screw conveyors, which feed it to the bed injection pipes. Fines that exit the boilers are separated at the 10-15: level from the gas stream by cyclones and reinjected into the bed. The boilers are designed for limestone and $\mathrm{NH}_{3}$ injection to control $\mathrm{SO}_{2}$ and $\mathrm{NO}_{\mathrm{x}}$ emissions.

\section{Colmac Energy Plant}

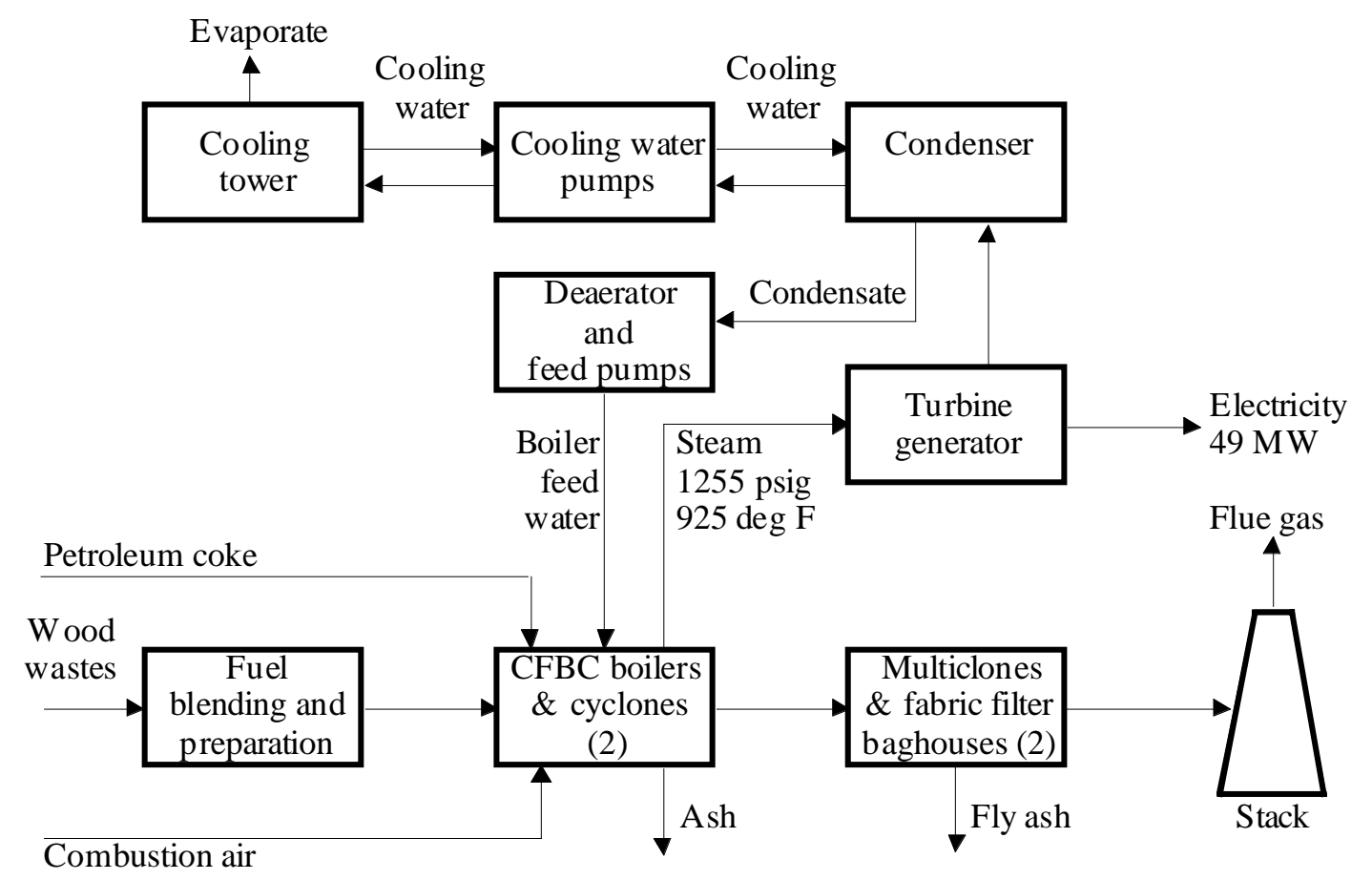

Colmac Energy has made numerous improvements to the boilers to improve operations and reduce maintenance costs. Modifications have been made to the vortex tubes, cyclone separators, grid nozzles, high-efficiency air preheaters, and furnace refractory. Natural gas input, which was required initially for flame stabilization, has been reduced to nearly zero.

\section{Turbine/Generator}

The turbine/generator is a nominal ABB 47-MW axial-flow unit. The generator has a highpressure, gear-driven turbine section on one end and a low-pressure section mounted on the opposite end. The condenser is mounted transversely at the low-pressure end.

\section{Fuel System}

The truck scale operator provides primary control for the plant's fuel deliveries, visually inspecting loads and ensuring that specified quality levels are maintained. Once admitted, the trucks are sequenced to the scale, to a dumper, and back to the scale. Two truck dumpers can each unload seven or eight trucks an hour under normal operating conditions. 
Fuel is dumped onto a dragchain feeder and conveyed to a radial stacker that forms a kidney-shaped stockpile $45 \mathrm{ft}$ high. The stacker automatically luffs and slews within an arc range set by the yard operator, who monitors stacking while operating other equipment in the area, such as chip dozers. Wood fuel is reclaimed from the kidney-shaped pile by either of two systems. One uses an underpile dragchain reclaimer similar to the dragchain device on the dumpers. Chips are stacked or dozed into a pile that buries the tail end of the reclaimer. The chips are reclaimed and discharged to a belt conveyor. The other system uses a boom-type overpile dragchain reclaimer. The boom luffs and slews and is gradually lowered as it reclaims layers of wood chips and discharges them to a belt conveyor. The overpile reclaimer requires a contoured pile face for a steady reclaim rate; to do this, it first dresses the pile to provide a smooth surface. It can then operate unattended for 8 or more hours.

From the belt conveyor, the wood chips are screened and hogged in a redundant system. Disk screens size the chips. These positive-displacement devices use rotating disks to move the oversized chips forward while the sized material falls between the screen openings. The sized material discharges directly to another belt conveyor. The oversized material from the head end of the screen is discharged to a wood hog. Most of the wood chips are within the required size range, so only a portion of the reclaimed material must be hogged. The reclaim design rate is $60 \mathrm{t} / \mathrm{h}$, the hog design rate is $20 \mathrm{t} / \mathrm{h}$.

The processed fuel is conveyed to the fuel metering bins. A belt conveyor carries the fuel to the first bin. The fuel discharges via a splitter gate to Unit 2's surge bin, or remains on the belt conveyor for Unit 1. The splitter gate can also divide the fuel to feed both units simultaneously. Bin level is controlled automatically via level sensors. The processed fuel has poor flow properties, so the metering bins are designed with a relatively low height to minimize compaction. Bin sidewalls have a negative slope (the bin's base is larger than its top) to avoid nonflowing areas caused by converging hoppers. The bins also have a $100 \%$ live bottom, using screw conveyors for discharge.

The fuel system must operate $100 \%$ of the plant's on-line time. Fuel system downtime is planned to coincide with scheduled and emergency maintenance on other plant systems. For this reason, the reclaim, processing, and plant feed systems are conservatively designed and feature redundant screens, hogs, and conveyor drives.

\section{Emissions Control}

Particulate emissions are removed in multiclones followed by pulse-jet fabric filter baghouses. Ammonia is injected to the flue gas for $\mathrm{NO}_{\mathrm{x}}$ control. The ash produced by the plant is used as a soil amendment and filler material for road construction.

\section{Balance of Plant}

The water treatment system includes a brine concentrator and demineralizer equipment that minimize the amount of effluent water. The crystallized solids end up with the ash. Cooling water is supplied through a closed system using a mechanical draft cooling tower. Each circulating FBC unit has an ID fan that discharges to a common stack. Electric power is transmitted to the utility via a $92-\mathrm{kV}$ line. 


\section{Fuels}

The plant design called for a total fuel requirement of 277,000 dry t/yr of biomass fuel, based on $85 \%$ plant availability. The design fuel mixture ranges were: wood waste, 85\%-100\%; agricultural waste, 0\%-15\%; municipal agricultural, 0\%-10\%. The wood waste specification called for clean wood by-products from commercial sources, with less than $1 \%$ paint, preservatives, glue, varnish, and foreign matter. Wood waste treated with creosote is not acceptable. The wood must be ground or chipped by the suppliers so $99 \%$ is smaller than 3 in. in all dimensions. The maximum allowable amount of foreign matter is $3 \%$; the maximum allowable moisture level is $35 \%$.

The plant design contemplated that the agricultural fuels would consist primarily of bales of straw and Bermuda grass. A bale processing line, including a bale feeder, unbaling station, tub grinder, and connecting drag conveyor, was provided. Shredded straw was to be blended with the wood fuel on its way to the boilers. In a 1995 presentation, Phillip Reese described the agricultural component of the plant's fuel as orchard removals and prunings (i.e., wood). How much experience the plant obtained with shredding bales of straw and conveying and combusting the shredded material is not clear, but not surprisingly that straw is no longer mentioned as part of the plant's fuel mix.

When petroleum coke is not being fired, the plant uses 1000 to $1200 \mathrm{t} / \mathrm{d}$ (including moisture content) of fuel, of which $80 \%-90 \%$ is urban wood waste from the greater Los Angeles area that would otherwise be deposited in landfills. The remainder of the plant fuel consists of agricultural residues, primarily from citrus and date orchard prunings and removals. Colmac collects the orchard wood at its own expense, and has been arguing for the state's air quality regulations to restrict the number and frequency of "burn days" permitted, or add a fee for a burn permit. This would increase the availability of agricultural wood wastes to the plant and shift some of the cost burden to the waste generators (growers).

The company's Mobile Grinding Services brochure shows a Morbark Model 1200 tub grinder and a Morbark Waste Recycler, as well as loaders with various buckets. The services offered include orchard grinding, land clearing for development, diversion site grinding, and construction wood waste grinding. To qualify as acceptable fuel for the plant, wood waste must be free of contaminants and noncombustibles, and must not be painted or treated with wood preservatives of any type.

Initially, the generators of urban wood wastes could avoid paying landfill tipping fees by delivering the wastes to Colmac's fuel suppliers, which accepted those wastes free. In 1995, Colmac began encouraging its fuel suppliers (there are many, and all are independent businesspeople) to charge tipping fees, and thereby reduce the cost of the fuel to Colmac. Colmac Energy has asked the state Waste Board to encourage diversion of the wood wastes to its fuel suppliers by, for example, instituting a surcharge on the landfill disposal of wood wastes where a biomass plant alternative is reasonably available.

Colmac Energy has been very active in improving its fuel mix, trying to reduce problems such as corrosion and fouling caused by potassium, sodium, and other elements in the biomass fuels. Recently, the plant received a permit to burn as much as $50 \%$ (by heat input) petroleum coke, which is about $6 \mathrm{t} / \mathrm{h}$ in each boiler. Operations with coke have been successful, although the price of coke is very cyclical. At times when coke prices are low, 
petroleum coke will provide fuel cost savings and operational benefits. During August 1998 the plant was burning a fuel mix of approximately $80 \%$ wood and $20 \%$ petroleum coke by heat input.

\section{Operating Experience}

During startup, a number of equipment malfunctions, wiring discrepancies, and control philosophy changes were experienced-none major. The size of the rotary fuel feed valves was increased to accommodate the varying density of the fuel. The valve motor operators were increased in horsepower and provided with reversing capability so any jams could easily be cleared. A modification was made to the boilers' wood storage day bin. To prevent potential motor overloads on the feed screws, the back portion of the bins was modified to stop biomass material from entering the last few feet of the screws. Changeout of control valve trim was required on three valves - the condensate minimum flow control valve, the desuperheater valve, and the auxiliary steam control valve. The actual flows and pressures varied from design by an amount sufficient to warrant trim changes but not valve body changes.

Overall, the plant operation has been highly successful, with high annual CFs and a low heat rate for a biomass plant, as described earlier.

\section{Environmental Performance}

No mention was made of any difficulties in complying with the plant's environmental permit requirements.

\section{Economic Information}

By the year 2002, the plant will have to cover its O\&M and fuel costs by selling power into California's competitive power exchange, plus any incentives that may be provided for biomass energy generation. The plant's actual O\&M costs have not been divulged. The EPRI BIOPOWER model estimates O\&M costs for a 50-MW circulating FBC plant to be about $1.7 \varnothing / \mathrm{kWh}$.

In early 1997 the plant manager mentioned that the plant's wood waste fuel costs were about $\$ 1.50 /$ MBtu (about $\$ 25-\$ 27 /$ dry t). At that time, petroleum coke costs were about $10 \%$ higher than wood fuel costs, not including the added costs for limestone sorbent, so the plant was not burning petroleum coke. In August 1998, the plant was burning about $20 \%$ petroleum coke, which indicates that the price for that fuel had dropped below the price of some of the wood fuel available to the plant.

Not knowing specific fuel prices, or what to project for future fuel prices at the Colmac plant, we can look at a range of possible values and convert them to $\phi / \mathrm{kWh}$ using a net plant heat rate of $12,400 \mathrm{Btu} / \mathrm{kWh}$ :

\begin{tabular}{|c|c|c|c|}
\hline Fuel, \$/MBtu & Fuel, $₫ / \mathrm{kWh}$ & $\underline{O} \& \mathrm{M}, \notin / \mathrm{kWh}$ & Total, $\phi / \mathrm{kWh}$ \\
\hline 1.50 & 1.9 & 1.7 & 3.6 \\
\hline 1.00 & 1.2 & 1.7 & 2.9 \\
\hline 0.50 & 0.6 & 1.7 & 2.3 \\
\hline
\end{tabular}


This hypothetical exercise shows that the plant could produce electricity for less than $3 \phi / \mathrm{kWh}$, if it can reduce fuel costs to $\$ 1 / \mathrm{MBtu}$ or lower. Other plants that burn urban wood wastes (e.g., Tacoma Steam Plant No. 2 in Washington and Ridge Generating Station in Florida) have shown that fuel costs can be reduced well below $\$ 1 / \mathrm{MBtu}$, and even below zero. To accomplish this the middlemen (fuel processors) must be eliminated and a tipping fee waste wood processing yard must be set up on the biomass plant site. Whether Colmac's location in the desert beyond Palm Springs (about $120 \mathrm{mi}$ from downtown Los Angeles) would be conducive to such an arrangement is questionable.

\section{Lessons Learned}

Colmac Energy was not willing to share what it considered to be the most important lessons learned from more than 6 years of operating the facility. The plant manager is clearly very proud of the plant and its operating record. The numbers $(\mathrm{CF}$, heat rate, etc.) are excellent. There is clearly a recognition that none of that would have been possible without the subsidy provided during the first 10 years of the ISO4 contract; there is real concern about the fate of the project without the high contract prices.

Lessons that can be inferred from the information above about the Colmac Energy project include:

- Urban wood waste can be a comparatively expensive fuel $(\sim 1.50 / \mathrm{MBtu})$ if the plant is located far outside the urban area. The transportation cost is significant, but more importantly, a distant plant probably has no alternative other than to contract for fuel with wood processing companies that are located in the urban area. Processors add at least $\$ 1-2 / \mathrm{MBtu}$ to the fuel cost. A properly located urban biomass plant derives income from its fuel rather than paying for it-but accomplishing this requires a location and a tipping fee structure that attracts wood waste generators with loads to dump. (Location, location, location!)

- Nonwoody agricultural residues such as straw cause much more trouble and expense than some design engineers realize. This can occur in all phases: collection, transport, storage, preparation, feeding, and combustion. If these types of agricultural residues are to be used as fuel, others who have used them successfully must be found and emulated.

- As at Tacoma, Colmac Energy has found it worthwhile to modify its permit to allow the use of petroleum-based waste fuels such as petroleum coke. At times, waste fossil fuels can be more economical than biomass. Allowing for such fuel flexibility during project development, design, and permitting phases is wise. 


\section{Sources and Contacts}

The bulk of the information in this section was obtained from two published sources:

- Power Magazine, April 1992. "Biomass Plant Relies on Variety of Local Fuels," by William Frazer, Daniel Mahr, and Peter Goldbrunner.

- Strategic Alliances for Biomass Energy, National Bioenergy Industries Association and Utility Biomass Energy Commercialization Association, Washington, DC, November 14-16, 1995. "Colmac Energy, Inc.-An Agricultural Residue and Urban Waste-Fueled Electric Power Plant,” by Phillip Reese.

Information was also provided by the plant manager, Graeme Donaldson, during telephone calls in February 1997 and August 1998.

Graeme R. Donaldson

Plant Manager

Colmac Energy, Inc.

62-300 Gene Welmas Drive

P.O. Box 0758

Mecca, CA 92254-0758

Phone: 760-396-2554

Fax: 760-396-2834 


\section{GRAYLING GENERATING STATION, GRAYLING, MICHIGAN}

The 36 MW Grayling Generating Station in north-central Michigan near Grayling provides electricity to a remote region, using wood waste material from local industries as fuel. The town's treated municipal wastewater is used as raw cooling water in the plant, which came on line in 1992. The plant operates as dispatched by the utility, typically cycling daily from its maximum capacity of $36 \mathrm{MW}$ during peak load periods to about $15 \mathrm{MW}$ during offpeak periods. From 1995 through 1998, the plant has consumed 289,000-347,000 t/yr of wood wastes (at 44\%-47\% moisture), and has generated 165,000-200,000 MWh/yr.

\section{Vital Statistics}

\begin{tabular}{lcccc} 
Design capacity, net MWe & \multicolumn{4}{c}{36} \\
Configuration & \multicolumn{4}{c}{ Traveling grate stoker boiler } \\
\hline Fuels-Wood wastes: & Hog fuel bark) & $35 \%-40 \%$ \\
& Forestry residues & $35 \%$ \\
& Mill residues & $25 \%-30 \%$ \\
\hline Year & 1995 & 1996 & 1997 & 1998 \\
Net generation, MWh/year & 182,400 & 186,500 & 165,994 & 199,843 \\
Annual CF, \% & 57.6 & 58.9 & 52.4 & 63.1 \\
\hline Net heat rate, Btu/kWh & \multicolumn{4}{c}{13,600} \\
Thermal efficiency, HHV, \% & \multicolumn{5}{c}{25.1} \\
\hline
\end{tabular}

The plant is owned by the Grayling Generating Station Limited Partnership. Members include Decker Energy International Inc., Winter Park, Florida; CMS Generation Co., a subsidiary of CMS Energy, Dearborn, Michigan; and Primary Power, Bay City, Michigan.

\section{History and Outlook}

A growing need for energy and environmental remediation made the Michigan location an ideal site for an integrated wood-fired power plant. Sandy soils in the region are not ideal for a wide variety of crops, but the use of lime to increase $\mathrm{pH}$ levels has helped sustain a healthy timber resource, which includes aspen, northern oak, jack pine, and white pine. Numerous small sawmills dot the hills and valleys.

By the early 1980s water purity had become a pressing local issue. Waste slab wood and sawdust from milling operations contributed to acidic pollution of streams and lakes, and the outdated sewage plant at Grayling was becoming inadequate. Grayling's city leaders set out to identify innovative engineering methods to solve these problems. After reviewing several options, spray irrigation of a 120-acre hybrid poplar plantation with treated 
wastewater was identified as a means of adjusting $\mathrm{pH}$ levels in the starved soils to improve growing conditions and to take full advantage of newly purchased pumping capacity. The concurrent planning and development of the 17-acre Grayling power station provided the opportunity for a direct link with the city sewage plant, improving the economics of both facilities.

Commercial operation began 90 days ahead of schedule; the owners took possession August 1, 1992. Plant startup was very smooth and performance has been excellent. Through March 1993, availability averaged higher than 95\%, including 5 days of scheduled outages. Through December 1998 the plant availability has averaged 96.2\%.

The plant is dispatched into the Consumers Energy Company system. Output fluctuates daily, typically between $10 \mathrm{MW}$ during off-peak hours and $36 \mathrm{MW}$ during peak hours. The bulk of the electricity produced (about one-half to two-thirds of the $36 \mathrm{MW}$ ) is consumed by major strand board and resin plants in the area; the remainder is distributed to local homes.

\section{Plant Flowsheet and Design Information}

\section{Grayling Generating Station}

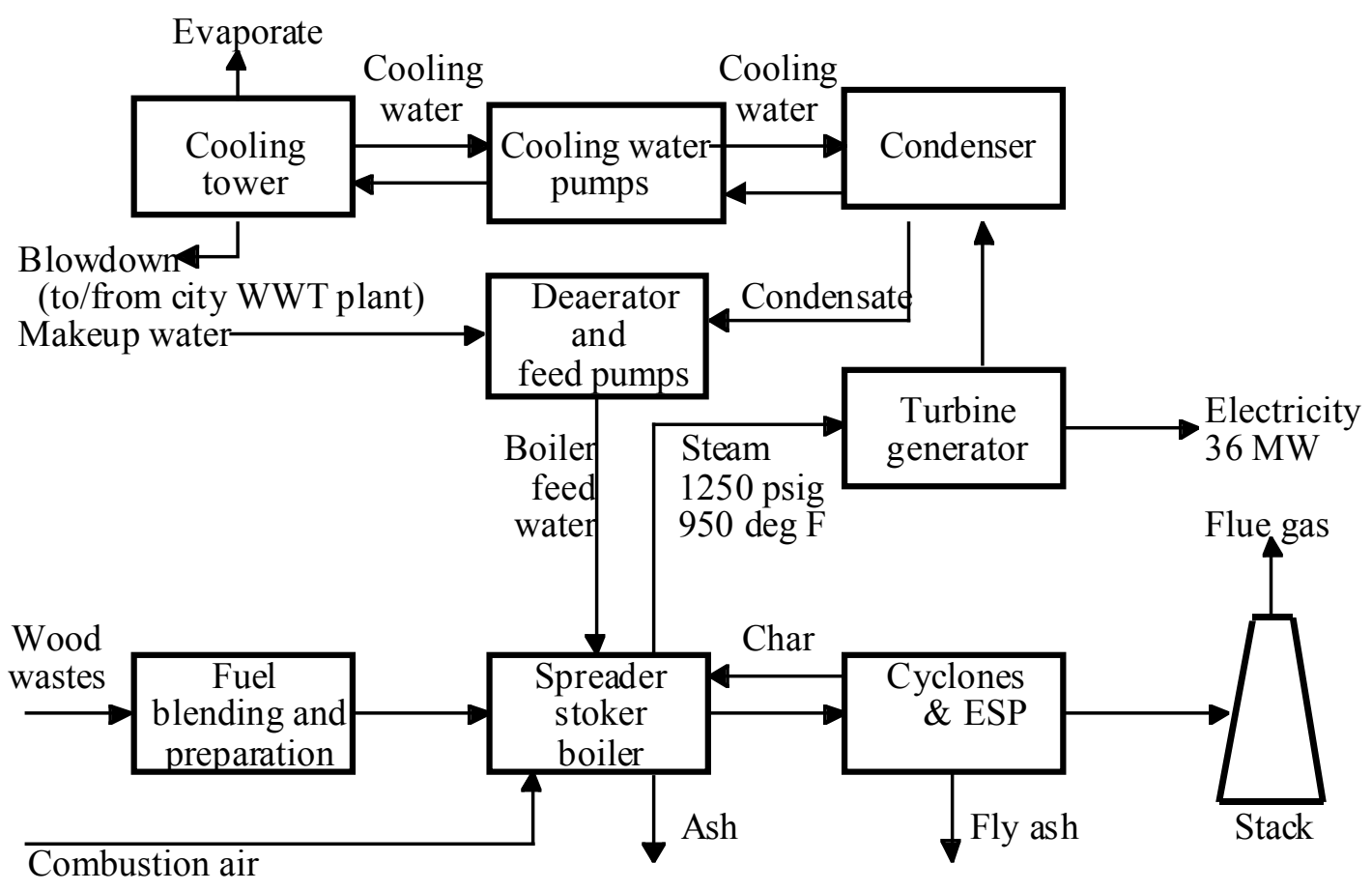




\section{Fuel System}

The fuel yard stores 45 days of fuel at $100 \%$ boiler capacity. As many as 7 weeks pass between the time fuel enters the yard and when it is sent to the furnace. This yard storage is necessary to provide adequate drying time. Fuel mix to the furnace averages $40 \%-45 \%$ moisture but may reach $50 \%$ after a heavy rain. High moisture levels adversely affect impact plant operation-conveyors plug up, fuel does not blow into the furnace efficiently, and $\mathrm{CO}$ emissions increase.

Fuel diversity requires a flexible materials handling system. Storage-pile management is critical. Truck dumpers unload directly to grade and mobile equipment handles storage and blending requirements to provide flexibility in fuel-receiving operations.

Fuel entering the plant is mixed into the fuel pile as it arrives and as it is moved into the short-term storage pile. Fuel yard operators use track-type dozers to spread and blend fuel to provide good mixture of fines and coarse material. Because of the high level of fines in the fuel, the belt-cleaning and return-belt systems were designed to minimize carry-back problems. All fuel conveyors are fully hooded.

\section{Boiler}

The plant uses a single Zurn Industries Inc., traveling grate spreader stoker boiler. Although stoker fired, the furnace resembles a pulverized-fuel design because of its ability to efficiently burn fines. Approximately $60 \%$ of the total combustion air is overfire and $40 \%$ is undergrate air-the reverse of most wood-fired boiler designs. Overfire air is supplied through four levels of front-wall and three levels of rear-wall ports. As much as $62 \mathrm{t} / \mathrm{hr}$ of fuel enter the furnace through six pneumatic distributors. Most of the fuel burns in suspension. The fuel/ash bed on the grate is relatively shallow. The boiler produces $330,000 \mathrm{lb} / \mathrm{h}$ of steam at $1250 \mathrm{psig}$ and $950^{\circ} \mathrm{F}$. The plant's net heat rate, as tested, is 13,600 $\mathrm{Btu} / \mathrm{kWh}$ (25.1\% thermal efficiency, HHV basis). Char collected in downstream cyclones and separated from noncombustibles is reinjected into the boiler.

The ability to use wood waste with a high fines content is a unique feature of Grayling. Forty to fifty percent of the fuel particles are smaller than $1 / 4$ in. The plant is designed to handle fuel with a higher heating value of $4500 \mathrm{Btu} / \mathrm{lb}$ and a moisture content of $48 \%$.

Magnesium oxide is used to control boiler slagging. It is added at the wood bins feeding the boiler and at the reinjection lines twice a day. The compound conditions the material so that the slag is loose, not glasslike, which makes it easier to remove from boiler tube surfaces with sootblowers.

\section{Char Reinjection}

Char is collected in cyclones downstream of the boiler, separated from noncombustibles, and reinjected into the boiler. Char reinjection lowers the carbon content of the fly ash and increases overall plant efficiency.

Steam Turbine/Generator

ABB Power Generation Inc., provided the steam turbine/generator. 


\section{Emissions Control}

Urea is injected into the upper sections of the furnace to reduce $\mathrm{NO}_{\mathrm{x}}$ emissions by $50 \%$. Injection lances/nozzles are located on the front and back walls in the upper third of the furnace. The system supplier fine-tuned the process with respect to nozzle opening size and spray patterns to minimize urea consumption.

Urea consumption depends on the nitrogen and moisture contents of the fuel being fired in the boiler and on plant load. Because the plant is on full dispatch by the utility, it operates at low loads, around $10 \mathrm{MW}$, during off-peak hours. During this time, urea injection is minimal. During peak periods, the plant is dispatched at 36.17 MW and the urea injection system is needed. Reagent consumption is approximately $0.56 \mathrm{gal} / \mathrm{ton}$ of fuel fired, or roughly 50\%-60\% of the design value. Dry fuel consumption leads to higher $\mathrm{NO}_{\mathrm{x}}$ levels and higher reagent consumption.

Fly ash is collected in a three-field ESP downstream of the cyclones. The plant has been permitted to land-spread fly ash in lieu of lime on farmland for adjusting $\mathrm{pH}$ upward. The $\mathrm{pH}$ of the ash is generally 12-13. The plant currently landfills the ash. This was an economic decision; the cost of landfilling is lower than the handling fee of the disposal company doing the land spreading.

\section{Water Treatment}

Scheduling and permitting considerations demanded innovative approaches to water management. No surface watercourses nearby can serve as discharge points. Options for discharge included percolation ponds, spray irrigation, or deep-well injection. All were cost and time prohibitive. Instead, the plant chose to intertie with the city's treatment plant to provide benefits to both parties.

Grayling Station takes water from the tertiary portion of the city's wastewater treatment facility to supplement the plant's makeup requirement, an average of $120 \mathrm{gal} / \mathrm{min}$. Plant operators manage and control the pumping systems in both directions to ensure that water taken for makeup is always in excess of that returned to the city for disposal. The warmer water that returns to the city sewage plant has been stripped of $\mathrm{NH}_{3}$; it therefore enhances waste treatment bacteriology. Discharges to groundwater in the Grayling area are avoided and the total discharge is reduced because of evaporative loss through the power plant cooling tower. With a $60 \mathrm{gal} / \mathrm{min}$ net reduction in water returned from the power plant, the City of Grayling estimates that its electricity bill for the pumping to irrigate poplar trees has been reduced by $17 \%$.

Water treatment at the plant includes primary and secondary strainers for solids and chlorination for biotreatment. The cooling water system features all stainless steel construction. During startup, cycles of concentration were high and defoaming agents necessary. Since then, optimum cooling tower cycles of concentration have been determined to be 6.5-7.0 and need for defoaming agents has been eliminated.

Staffing

The plant has 26 employees. 


\section{Fuels}

An average of 40 trucks/d deliver sawmill and forestry wastes. About $35 \%-40 \%$ of the waste wood is bark processed by hammermills; about $35 \%$ is composed of chipped tree limbs and tops left over from forest management practices mandated by the Michigan Department of Natural Resources; and the remaining 25\%-30\% is made up of clean fuels such as sawdust, shavings, and scraps from sawmills and maple block production mills. AJD Forest Products, a local lumber company that is $50 \%$ owned by the Grayling Station, acts as procurement manager for the fuel, collecting and processing wood waste from more than a dozen sawmill sites. The City of Grayling brings its tree trimmings to AJD for processing and inclusion in the fuel mix.

Actual figures for wood waste fuel consumption by the Grayling Station were 289,368 $\mathrm{t}$ for calendar year 1997 with an average moisture content of $47.4 \%$, and 337,486 t for January 1 through December 21, 1998 with an average moisture content of $44.3 \%$.

The plant recently received a permit to test burn TDF, and initiated the test burns in midDecember 1998. The fuel is delivered in the form of 2-in. chips. The initial observation after the first tests is that more of the wire needs to be removed from the TDF. The ash is landfilled (and no longer used as a soil amendment), so the effects of zinc and other components in the TDF on the ash properties are not major concerns.

\section{Operating Experience}

Some equipment changes have been made since startup. The hopper under the air heater was modified to avoid the recirculation and subsequent slagging of heavy sand. Plates were installed to divert flow from the air heater to the ESP hopper and a sand classifier that keeps sand out of the fly ash transport system. Original level detectors in the live-bottom fuel feed bunkers were not sensitive enough and were replaced with ultrasonic level detectors. Screw feeders were modified to prevent bridging that occurred during startup caused by high levels of bark in the fuel. In 1997, the ID fan wheel was replaced; ash buildup on the fan had caused vibration, and stress cracks had developed in the wheel.

The Grayling Station's statistics on annual availability and CF for 1995 through 1998 are shown below:

\begin{tabular}{llrrrr} 
& & 1995 & 1996 & 1997 & 1998 \\
\cline { 3 - 6 } Availability, \% & on-peak & 96.09 & 97.89 & 97.04 & 96.99 \\
& off-peak & 96.56 & 97.61 & 98.35 & 96.48 \\
& total & 96.36 & 97.73 & 97.78 & 96.70 \\
\hline \multirow{2}{*}{ CF, \% } & on-peak & 68.14 & 72.17 & 69.67 & 81.19 \\
& off-peak & 49.40 & 48.51 & 38.78 & 48.81 \\
& total & 57.58 & 58.85 & 52.39 & 62.99
\end{tabular}

The plant was dispatched more often in 1998 than in previous years, as the cap on the price at which the plant can bid its power was reduced. (This cap is based on the operating costs of five large coal plants, and is included in the contract for sale of electricity to Consumers Energy.) 


\section{Economic Information}

Questions concerning Grayling's project cost recovery and its sales contract with the utility were resolved in 1987 after the state passed a law requiring utilities to buy power at a fixed rate for the duration of project financing. Total project cost, including engineering, construction, and financing, was $\$ 68$ million, or $\$ 1878 / \mathrm{kW}$.

The contract stipulates that Consumers Energy will buy electricity for $6.2 \phi / \mathrm{kWh}$. Built into the rate is $4.05 \phi / \mathrm{kWh}$ for capacity, $0.4 \phi / \mathrm{kWh}$ for O\&M, and $1.75 \phi / \mathrm{kWh}$ for the energy (now $1.65 \phi / \mathrm{kWh}$ ), based on the price of coal. Transportation and handling contribute most to the plant's fuel costs.

\section{Lessons Learned}

The Grayling plant started up with no significant problems and has run with excellent performance for more than 6 years. There have been no major equipment problems and staff members could think of no major "lessons learned."

The project was planned and the plant designed with a waste management role in mind, and efforts were made to fit positively into the local economic and environmental landscape. Some planned environmental benefits have not worked out (e.g., the ash is landfilled instead of being used as a soil amendment), but overall the plant has clearly created benefits for the local economy and environment.

Like several other biomass power plants, the Grayling Station is operated as a cycling plant. It has run at about a 70\%-80\% CF during peak demand periods, and at about a $40 \%-$ $50 \%$ CF during off-peak periods.

\section{Sources and Contacts}

The information in this section is based on an article in the April 1993 issue of Power Magazine; an article in the CADDET Renewable Energy Technical Brochure No. 16, 1995; and information posted on the CMS Energy web site (cmsenergy.com). Philip Lewis, plant operations and maintenance superintendent, provided additional information in February 1997 and December 1998.

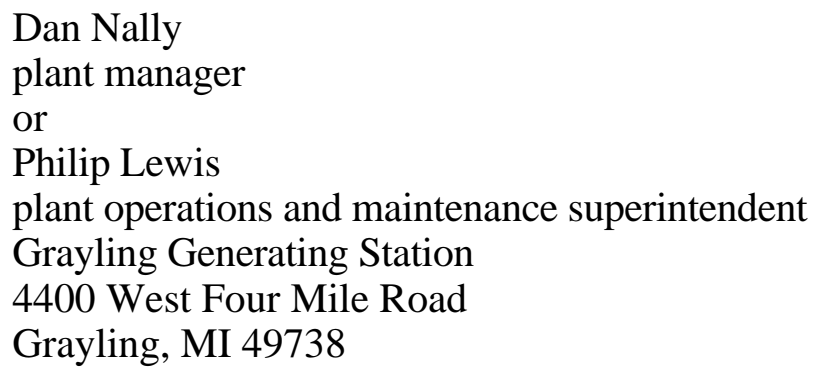

Phone: 517-348-4575 


\section{WILLIAMS LAKE GENERATING STATION, BRITISH COLUMBIA, CANADA}

The Williams Lake Generating Station in British Columbia is located about $225 \mathrm{mi}$ north/northeast of Vancouver and is the largest single-unit biomass-fired power plant in North America. Originally a limited partnership (two-thirds owned by Inland Pacific Energy Corp. and one-third owned by Tondu Energy Systems, Inc.), NW Energy (Williams Lake) Corp. is now wholly owned by B.C. Gas Inc. The plant's rated capacity is $60 \mathrm{MW}_{\mathrm{e}}$ net, of which $55 \mathrm{MW}$ is purchased by B.C. Hydro under contract. The plant can produce 67-69 MW net, and frequently operates at that production level when it can sell its excess energy through Powerex, a marketing affiliate of B.C. Hydro. The plant's annual CF has actually exceeded $100 \%$ for several years.

\section{Vital Statistics}

\begin{tabular}{lcccc}
\hline $\begin{array}{l}\text { Design capacity, net MWe } \\
\text { Con figu ration }\end{array}$ & \multicolumn{4}{c}{60} \\
Fuels & \multicolumn{4}{c}{ Water-cooled vibrating grate boiler } \\
Wood wastes (mill residues)
\end{tabular}

*Projected in December1998.

\section{History and Outlook}

The Williams Lake region was often beset with layers of smoke and a generous sprinkling of ash particles from wood waste burners at the five local sawmills. Beginning around 1988, concerted action by the provincial government, the local utility, the sawmill owners, and the public resulted in construction of Williams Lake station.

Commercial operation started on April 2, 1993. By year's end, all performance goals were met or exceeded. The CF for the first 9 months was $91.6 \%$, with a forced outage rate of less than $5 \%$. In each of the five following years the plant has generated more than 500 $\mathrm{GWh} / \mathrm{yr}$ and consumed more than 550,000 tons/yr of mill residues.

The Williams Lake Generating Station not only has the largest wood-fired boiler in North America and generates more electricity each year than any other wood-fired power plant; it is also the most efficient stand-alone wood-fired power plant in North America, with a net 
plant heat rate of about $11,700 \mathrm{Btu} / \mathrm{kWh}$. With nearly free fuel, efficiency is not a major priority at Williams Lake. However, the steam conditions, auxiliary power consumption, and turbine efficiency are considerably better than those at smaller plants, and Williams Lake runs consistently on very high-quality wood fuel, generating about $73 \mathrm{MW}$ gross and 67-68 MW net, about $12 \%$ above its design capacity.

\section{Plant Flowsheet and Design Information}

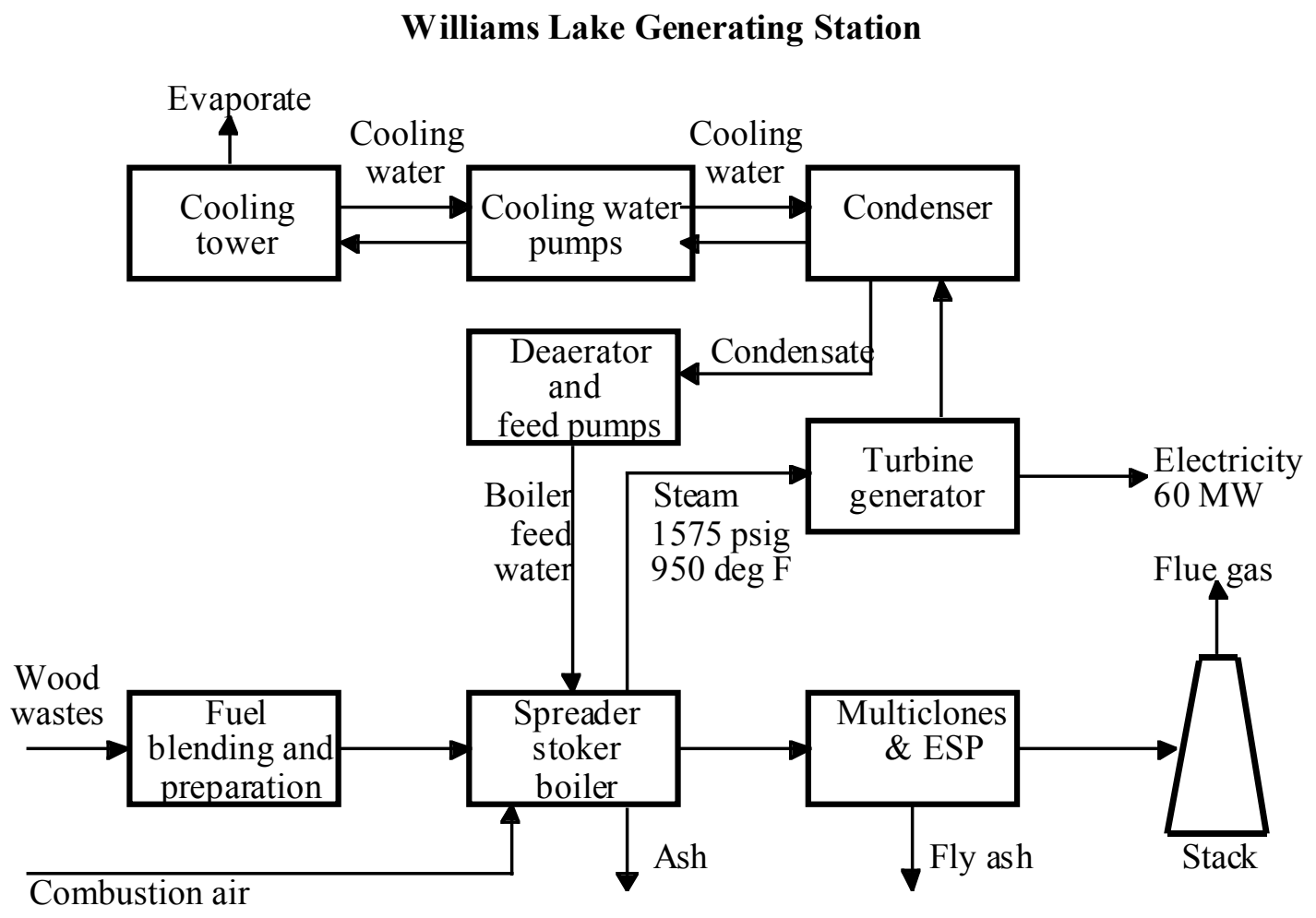

Fuel System

The fuel is processed on site through a magnet to remove ferrous metal and a disk screen to reject oversized material. The fuel yard has a $60-\mathrm{d}$ storage capacity, and more than 3600 $\mathrm{ft}$ of conveyor belts. The fuel is piled $40 \mathrm{ft}$ high on a graded stockpile area of about 400,000 $\mathrm{ft}^{2}$. The extensive fuel handling system takes advantage of the slope of the site to minimize the number of pits required for the conveyor system. The arrangement also takes into account winter-related access problems for fuel trucks.

An 82-ft x 10-ft, 75-t scale weighs incoming and outgoing trucks. An 82-ft hydraulic truck dumper (75-t capacity) and a $57 \mathrm{ft}$ truck dumper (60-t capacity) dump fuel into live bottom receiving hoppers. Drag conveyors in the bottom of each hopper convey the fuel to a single $300-\mathrm{t} / \mathrm{h}$ outfeed conveyor. A slow-turning spiked roll breaks up fuel clumps as the stream exits each hopper. 
An oversized-fuel infeed hopper/conveyor is provided alongside the two truck dump hoppers to introduce oversized fuel to the processing system. This fuel is dumped onto the pavement in the truck dump area, and loaded onto the fuel-infeed hopper/conveyor by a front-end loader.

The outfeed conveyor has a self-cleaning magnet to remove ferrous materials. A metal detector further down the conveyor trips the belt if it detects metal. The outfeed conveyor delivers fuel to a $300 \mathrm{t} / \mathrm{h}$ disk screen, which removes material larger than $3 \mathrm{in}$. from the fuel stream. Accepted fuel is deposited directly onto a troughed scalper/hog outfeed conveyor $(300 \mathrm{t} / \mathrm{h})$. Scalper rejects are fed to a $75-\mathrm{t} / \mathrm{h}$ wood hog and then to the outfeed conveyor. An electromechanically actuated hog bypass can divert rejects to a paved apron area; a frontend loader can return oversized fuel from there to the infeed hopper.

The scalper/hog outfeed conveyor transports sized fuel to a stackout conveyor. This is situated $60 \mathrm{ft}$ above stockpile grade level and is fitted with a plow. The plow drops fuel adjacent to the fuel reclaim area. Both the stackout conveyor discharge, which terminates near the center of the stockpile, and the plow discharge are fitted with extended chutes. A bladed, tracked vehicle moves incoming fuel from the stackout conveyor drop points to appropriate areas of the pile or to the reclaim area.

Two automatic, back-to-back, radial overpile reclaimers $(140 \mathrm{t} / \mathrm{h})$ drag fuel from the surface of the stockpile to flight-type transfer conveyors. Each reclaimer has a total livestorage volume of at least $12 \mathrm{~h}$ at the plant's maximum continuous rating. The transfer conveyors deposit fuel on a reclaim outfeed conveyor for delivery to a disk screen. The reclaim outfeed conveyor exits the stockpile area via a concrete tunnel. A magnet is positioned at the conveyor head pulley. Accepted fuel smaller than 3 in. passes through the disk screen onto a 140-t/h boiler feed conveyor. Disk screen rejects are chuted to a paved apron area at grade for recycle by mobile equipment. A disk screen bypass chute with a manually actuated flop gate is provided.

The boiler supply conveyor delivers fuel to a boiler cross-feed conveyor that distributes fuel in turn to each of seven boiler fuel surge bins. It is of the flight-conveyor type arranged for top carry and bottom feed. The excess fuel remaining after traversing the fuel surge bins is deposited onto a stockpile return conveyor. The transfer points to and from the cross-feed conveyor are isolated from the boiler building air space to minimize fugitive dust in the boiler building. Knife gates provided in the outlets from the cross-feed conveyor to each fuel bin allow maintenance activities to be isolated.

The stockpile return conveyor $(140 \mathrm{t} / \mathrm{h})$ delivers excess fuel to a transfer point. By means of an electrically actuated flop gate, the material can either be deposited on the stackout conveyor for return to the stockpile or chuted back to the boiler supply conveyor. Both the boiler supply and stockpile return conveyors are equipped with belt scales wired into the DCS.

The only area of the plant that was modified after startup was the fuel handling system. Minor modifications were made to improve performance, such as:

- Adding the ability to reverse the dragchains on the dumper hoppers, to make unplugging fuel jams easier. 
- Adding three more rolls to each disk screen (12 rolls were provided originally), to reduce the carryover of fine particles that tended to plug up the hog.

Boiler

The boiler is a two-drum, top-hung watertube design delivering 561,750 lb/h of $1575 \mathrm{psig}$, $950^{\circ} \mathrm{F}$ steam when burning design fuel with $33 \%$ excess air. Steam temperature is controlled by interstage superheater attemperation.

Combustion takes place on and over three vibrating water-cooled grates inclined about $6 \%$ from horizontal. With each grate vibrated intermittently, burning fuel and ash slide during operation from the rear of the furnace to the front, where ash falls into a water-filled ash hopper. Intermittent vibration also prevents ash deposits from forming and helps maintain free fuel flow. Incoming fuel is evenly spread over the upper portion of each grate by airswept distributor spouts located on the front furnace wall. Small particles entering the furnace are burned in suspension; larger pieces burn on the grate. About $75 \%-80 \%$ of the fuel particles are smaller than $1 / 4$ in.

The boiler furnace provides residence time longer than $3 \mathrm{~s}$ at guaranteed conditions to achieve sufficient carbon burnup without reinjecting char. Balanced draft is employed with a single FD fan supplying inlet air to the furnace, an ID fan discharging flue gas, and a fuel distribution air fan supplying motive air to the fuel distributor spouts. A tubular air heater heats combustion air from the FD fan before it enters the furnace.

\section{Turbine/Generator and Auxiliaries}

The turbine is designed for throttle steam conditions of $1550 \mathrm{psig} / 950^{\circ} \mathrm{F}$, and 2.5 -in. $\mathrm{Hg}$ abs exhaust pressure at design ambient conditions. Three uncontrolled extraction points for feedwater heating are included. The turbine/generator provides a guaranteed net electric output of $60 \mathrm{MW}$ (with capability for 67-68 MW under most conditions). The generator is an air-to-water cooled unit rated as follows: 0.90 power factor lagging to 0.95 power factor leading, three phase, $60 \mathrm{~Hz}$, and $13.8 \mathrm{kV}$.

The condenser rating is based on a tube cleanliness factor of 0.85 . Condenser tube material is Type 304 stainless steel. Two 100\%-capacity, two-stage steam-jet air ejector (SJAE) sets are provided, each capable of taking condenser vacuum from 10 -in. $\mathrm{Hg}$ abs to design vacuum in $1.5 \mathrm{~h}$. Condensate-cooled inter- and after-condensers are stainless steel tubed. One single-stage hogging injector is capable of drawing condenser vacuum from atmospheric pressure down to 10 -in. $\mathrm{Hg}$ abs in $30 \mathrm{~min}$.

Two 100\%-capacity, canned, vertical, turbine-type, condensate extraction pumps move condensate from the condenser hotwell through the SJAE condensers, the turbine-gland steam condenser, and the low-pressure feedwater heater to the deaerator. A minimum-flow recirculation line is provided for the condensate extraction pumps downstream of the gland-steam condenser.

\section{Emissions Control}

Flue gas passes to the stack through a mechanical dust collector, the ID fan, and an ESP. Fly ash is removed at three locations: the convection and air heater sections of the boiler, the mechanical dust collector, and the ESP. The dust collector consists of a multiplecyclone-type separator with $70 \%$ minimum removal efficiency. The ESP has five fields, 
and is sized to meet the particulate emissions limit of $0.02 \mathrm{gr} / \mathrm{dscf}$ with one field out of service. Heated hoppers sized for $12 \mathrm{~h}$ of material storage are included in the ESP design.

On-line stack gas analyzers (CEMs) continuously monitor and record $\mathrm{NO}_{\mathrm{x}}, \mathrm{CO}, \mathrm{O}_{2}$, and opacity emissions. CEM system outputs are directed to the DCS and average emission levels are computed. The CEM system also contains a strip-chart recorder to record output of each analyzer.

\title{
Plant Control
}

The DCS provides analog and sequential (logic) control capabilities in one reliable integrated system. The system monitors, alarms, archives, and logs instrument signals from selected facility equipment. It also interfaces with turbine/generator controls for load control and shutdown functions. The operator can manipulate analog control loops, using setpoint adjustments or manual control, and can start or stop process equipment from computer control stations on the operator's display unit.

Key Suppliers

Turnkey contractor

Constructor

Boiler island engineer

O\&M mobilization

Steam generator

Steam turbine/generator

Boiler feedpumps, motors

Boiler feedpump turbine

Boiler makeup demineralizer

Fuel handling/conveying system

Fuel reclaimers

Truck dumpers/hoppers

Truck scale

Digital control system

FD and ID fans

Ash handling system

Hydrograte

ESP

Dust collector

Air compressors

Bridge crane

Stack

Circulating water pumps

Main transformer

Voltage transformers

Motor control centers

\author{
CRS Sirrine Engineers Inc. \\ TNL Construction Ltd. \\ The McBurney Corp. \\ Sterling Energy Operations Inc. \\ Babcock \& Wilcox Canada \\ General Electric Co. \\ KSB Inc., Westinghouse Electric Corp \\ Dresser-Rand Co. \\ Glegg Water Conditioning Inc. \\ Power Tech \\ Industrial Services Inc. \\ Phelps Industries Inc. \\ Western Scale Co. \\ Bailey Controls Co. \\ Buffalo Forge Co. \\ Ash Tech Corp. \\ Detroit Stoker Co. \\ Environmental Elements Corp. \\ Zurn Industries Inc. \\ Ingersoll Rand Co. \\ Zenar Corp. \\ Power Tech \\ Thermal-Dynamic Towers Inc. \\ Hyundai Corp. \\ ABB Inc. \\ General Electric Co.
}

Staffing

Williams Lake Generating Station has a full-time staff of 30 employees, including 15 operators. 


\section{Fuels}

The plant consumes more than 550,000 green t/yr of wood waste from sawmills in the Cariboo region. Five sawmills, located within $5 \mathrm{~km}$, supply the fuel at no cost, and receive value from alleviating an environmental liability of waste disposal. Because the mills are so close to the plant, conveyor belts were considered, but short haul trucking is used to transport the fuel. The power plant pays for the transportation, and paid approximately $\$ 2$ million to install fuel preparation equipment at each sawmill. The sawmills pay the operating expenses for the fuel preparation equipment.

The fuel mix is approximately $40 \%-50 \%$ bark; the rest is an assortment of sawdust, chips, and slabs. Fuel specifications include moisture content of 35\%-55\%. Typical fuel moisture content during the summer is 37\%-38\%; during the winter, 50\%. By hogging and blending at the mills, the plant has been able to maintain consistent fuel quality. The plant can also use pulp-quality chips because there are no paper mills in the vicinity.

\section{Operating Experience}

The plant has run well, with more than $94 \%$ or higher average availability and production statistics as noted earlier. From 1996 to 1997, corrosion was noted in the cold end of the air heater. The air heater was retubed during a scheduled turnaround in 1997.

In May 1998, during a scheduled outage, a major overhaul of the steam turbine found some water erosion in the back end, resulting in an extra week of downtime. In June, the turbine tripped, and during an unscheduled 2-wk outage the stationary turbine components were found to have been reinstalled slightly too high.

During the May 1998 scheduled outage, some fireside corrosion was found in the boiler (superheater and air heater). A small amount of chloride in the fuel is believed to interact with ash and slag deposits on the tubes to cause the corrosion. Some tubes were replaced with 310 stainless steel. One specific source of fuel (referred to as the Ainsworth hog) at an oriented strand board mill contains aspen bark and limbs with a relatively high potassium content. This fuel source may be eliminated if the corrosion problems persist. Various options, including reducing furnace exit gas temperatures, water injection, and stainless steel inserts or tube sections in the last 5 or $6 \mathrm{ft}$ of the air heater, where the flue gas reaches its dew point, are being explored with B\&W's help.

Improvements to the fuel handling equipment made shortly after startup were noted earlier. More recently, the seven sets of dual screw feeders were replaced because of erosion. The pitch was changed, and the cones were extended to $8 \mathrm{ft}$ over the $12-\mathrm{ft}$ length of the screws. The slopes of the bin walls were changed to alleviate bridging and compression of the fuel.

As mentioned earlier, efficiency (heat rate) is not a high priority because the fuel is almost free. However, the relatively high steam temperature and large unit size give the Williams Lake Generating Station a low heat rate (high conversion efficiency) compared to other biomass power plants. The unit consumes approximately $46 \mathrm{dt} / \mathrm{h}$ of fuel while producing a net output of $67 \mathrm{MW}$. Assuming an HHV of 8,500 Btu/lb for wood on a dry basis, the net plant heat rate is $11,700 \mathrm{Btu} / \mathrm{kWh}(29.2 \%$ conversion efficiency, HHV basis). The contract with the boiler manufacturer guaranteed a net plant heat rate of $13,753 \mathrm{Btu} / \mathrm{kWh}$, but the plant achieved an actual net heat rate of 11,663 Btu/kWh during the 72-h performance test. 


\section{Environmental Performance}

Diverting wood residue from the local sawmills resulted in closure of their beehive burners. This reduced particulate emissions by more than $95 \%$, solving a severe and longstanding local air pollution problem. The state-of-the-art facility is equipped with combustion and emission controls including multiclones and a five-field ESP. The plant was designed to surpass the air emissions permit levels, that are already five times tighter than current regulations for wood waste-fired boilers. The power from this regionally sustainable, environmentally beneficial project enables B.C. Hydro to defer construction of other power projects.

\section{Economic Information}

More than 275 person-years of employment were created during the 2-year construction period; $50 \%$ of the craftspeople were hired from the Williams Lake area. The continuing operations of the plant provide 28 direct and 15 indirect permanent jobs. More than $90 \%$ of the operating staff were residents of B.C. when hired. The plant solved a major solid waste disposal problem facing local sawmills, thereby improving its competitiveness and stability.

The total capital cost was reported as $\$ 150$ million (Canadian), including off-site wood processing equipment. (At U.S. $\$ 0.80$ to the Canadian dollar, this was about U.S. $\$ 125$ million, or $\sim \$ 2100 / \mathrm{kW}$.) Specific information on O\&M and fuel costs was not provided, but the plant design and performance figures indicate that Williams Lake is one of the lowest-cost biomass power plants operating today. The fuel cost is almost certainly less than $1 \phi / \mathrm{kWh}$, and the O\&M cost is probably less than $1 \phi / \mathrm{kWh}$ as well.

\section{Lessons Learned}

The plant engineer feels that overall, the boiler and turbine/generator systems are excellent. The boiler is generous, the turbine/generator is robust, and the ESP is overdesigned. The fuel handling system needed some reworking. Tramp iron removal locations needed to be moved, dust control systems needed improvement, and the reclaimer structures needed redesigning to more evenly distribute the stress. Staying on top of maintenance programs at all times is essential.

As long as the mills continue to operate and provide the fuel, no major issues are on the horizon for the Williams Lake Generating Station. With uncertainty in the forestry industry, unknown impacts of Asian market upheaval, high provincial stumpage fees, and closure of some coastal sawmills and pulp mills, the biggest long-term threat to the plant appears to be fuel availability. 


\section{Sources and Contacts}

Some of the information was obtained from an article in Power Magazine (April 1994) written by Jim Ford of Tondu Energy Systems Inc. More recent information was provided by Gerry Arychuk (the plant's chief engineer, who retired in 1997) and Colin Kozak, general manager.

Colin Kozak

General Manager

NW Energy (Williams Lake) Corp.

4455 Mackenzie Avenue North

Williams Lake, B.C. V2G 1M3

Phone: 250-392-6394

Fax: 250-392-6395 


\section{MULTITRADE PROJECT, HURT, VIRGINIA}

The world's largest stand-alone wood-fired power plant came on line in June 1994 in Hurt, Virginia. The 85.1-MW (79.5-MW net) independent power plant was built under contract to Virginia Power as the result of an open solicitation for additional power. The plant provides peaking power on demand from the utility and has operated at annual CFs of 10\%-20\%. The capacity payment that Virginia Power pays under the 25-year contract keeps the plant operating at these low CFs.

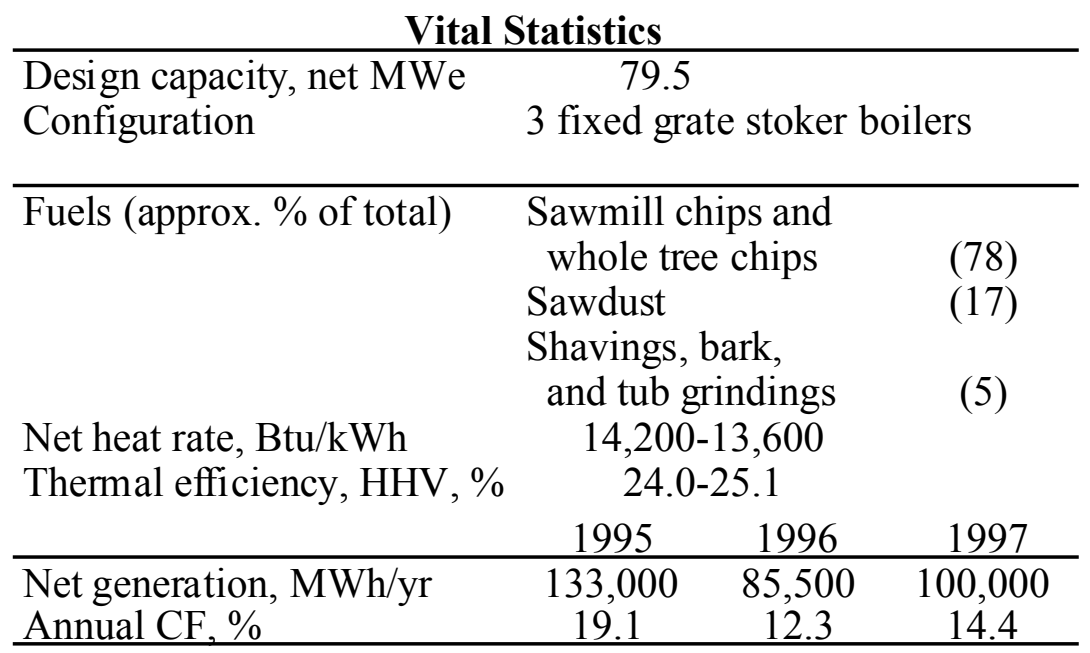

\section{History and Outlook}

Multitrade Group of Ridgeway, Virginia, received the original contract from Virginia Power and built the plant at a total cost of $\$ 114$ million. The general partner in the limited partnership that now owns the plant is ESI Energy, a wholly owned subsidiary of FPL Group, and an original investor in the plant. The FPL Group has other holdings, including Florida Power \& Light (FPL). Hurt is located in south central Virginia about 20 mi south of Lynchburg and 100 miles north of Greensboro, North Carolina.

Construction on the project started in November 1992 after more than 4 years of battles and $\$ 4$ million in expenses to obtain 28 permits to construct and operate the plant. Plant startup began in December 1993, and commercial operation began in June 1994. The plant operates on a dispatchable basis for Virginia Power and was operated at $10 \%$ of its capacity during the first month. 
Originally, investors would not participate in the project without assurance of long-term fuel supplies. Fuel suppliers either would not sign such contracts or it was deemed impossible to enforce such contracts. Adequate fuel supplies have been developed in the area, and continue to be developed to provide investor confidence.

The Multitrade plant's role is to provide $79.5 \mathrm{MW}$ of capacity on Virginia Power's system. A peaking plant, it burns $100 \%$ wood, none of which can originate from potentially contaminated sources such as pallets or construction/demolition debris. Virginia Power normally provides $12 \mathrm{~h}$ notice to Multitrade, at 6:00 p.m., that the plant needs to be generating at 6:00 a.m. During some seasons, weeks go by without being dispatched. On January 20, 1998, for example, the plant had not operated since December 30, 1997.

\section{Plant Flowsheet and Design Information}

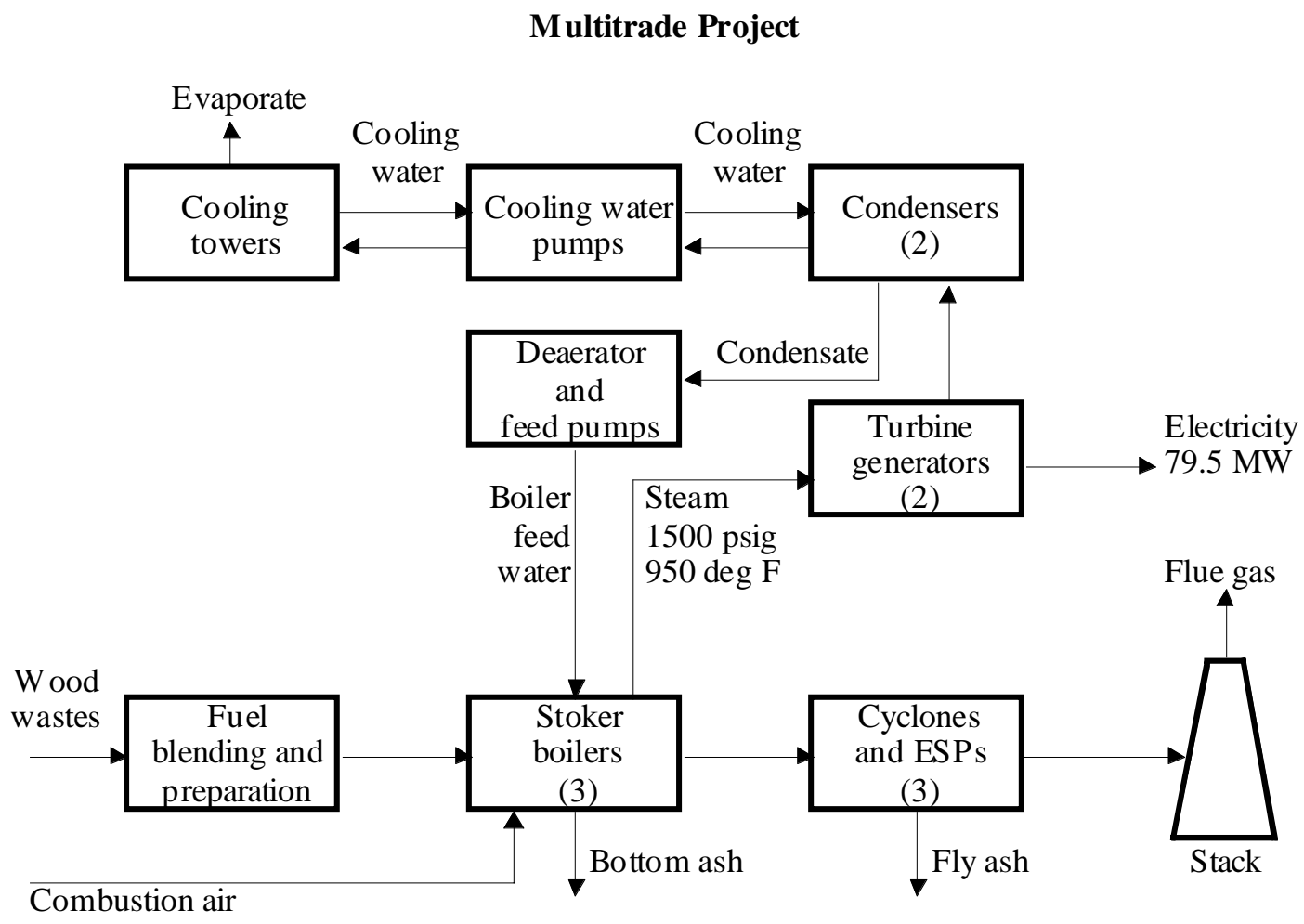

\section{Boilers}

Three fixed-grate Riley Stoker boilers generate steam at 1500 psig and $950^{\circ} \mathrm{F}$ from the wood waste fuel. The design steam rate for each boiler is $242,000 \mathrm{lbs} / \mathrm{h}$, and the boilers are rated at 250,000 lbs/h each. The design plant output of 79.5 MW (net) can be achieved with the boilers each generating about $239,000 \mathrm{lbs} / \mathrm{h}$ of steam. Steam blowers are used to clean the fixed grates when the boilers are operating at low load.

\section{Turbine Generators}

Two ABB steam turbine/generators generate electricity (85.1 MW gross, 79.5 MW net). 


\section{Water System}

Cooling water for the condensers is cooled in cooling towers. Makeup cooling water and boiler feed water come from the Staunton River. The water is held in a raw water storage reservoir, filtered, and stored in a tank for process use. Cooling tower blowdown is dechlorinated and returned to the Staunton River.

\section{Ash Removal}

Bottom ash from the boilers is combined with fly ash from the cyclone separators and ESPs in an ash silo. Ash conditioner can be added as the ash is dumped from the silo into trucks.

\section{Fuel System}

To facilitate movement of fuel supply trucks, two scales weigh trucks in and out of the plant. Two dumpers that can tilt the whole truck are used. Truck drivers carry magnetized cards that are scanned at the scales to track fuel purchases. This system allows the fuel supply trucks to unload and exit the plant within 12 min after entry.

The plant is required by contract to maintain at least $15 \mathrm{~d}$ of fuel in storage. Fuel is stored in an open pile with a maximum height of $30 \mathrm{ft}$, and a first-in, first-out system of storage management is used to minimize heat buildup. The maximum amount of wood fuel stored in the pile is about $82,000 \mathrm{t}$. Under full load the plant consumes $2900 \mathrm{t} / \mathrm{d}$ of wood.

\section{Emissions Control}

Urea is injected into the flue gas from each boiler for $\mathrm{NO}_{\mathrm{x}}$ control. Each boiler has a cyclone collector and an ESP to remove fly ash. The flue gas from the three ESPs is combined and exhausted through a single stack.

\section{Staffing}

Twenty-six people are employed at the plant, including the general manager, an operations manager, an administrative manager, a maintenance manager, a fuel procurement manager, a maintenance crew of three mechanics, and four, four-person crews to operate the plant. Each shift works $12 \mathrm{~h}$, rotating 4 days on and 4 days off.

\section{Fuels}

Fuel is purchased entirely on the spot market and averages around $\$ 12 /$ green t. Chips from sawmills and whole tree chippers account for about $78 \%$ of the total fuel and average about $\$ 14 / t$; sawdust accounts for about $17 \%$ of the total fuel and averages about $\$ 9 / t$; shavings, bark, and tub grindings account for about $5 \%$ of the total fuel and average about $\$ 11 / \mathrm{t}$. The fixed grate boilers operate very well with fine fuel sizes. The plant has used as much as $45 \%$ sawdust in the fuel blend. The maximum particle size specification is 4 in., although smaller than 2.5 in. is preferred. The moisture content averages about $40 \%-45 \%$ for chips and sawdust.

The fuel yard is kept at least half full at all times to be ready for full-capacity operation. The plant buys from about 225 fuel vendors throughout southwest Virginia, plus 16 or 18 counties in North Carolina, and one county in Maryland. The effective fuel supply radius is about $200 \mathrm{mi}$. Within a 30-mi radius or so, there are three large paper mills and three 
strand board plants, all of which are in the market for large quantities of biomass fuel. Multitrade has established cooperative relationships with several of these plants, mostly to keep fuel suppliers in business by coordinating with each other during periods of fluctuating wood procurement rates.

\section{Operating Experience}

The plant has been technically and financially successful. All major milestones were met on schedule, and the plant has consistently supplied power to the grid, and profits to its owners, on schedule. "Readiness" is the primary priority for a peaking plant.

The guaranteed heat rate was $14,447 \mathrm{Btu} / \mathrm{kWh}$ and startup tests verified this heat rate. During commercial operation the net plant heat rate has ranged from 14,200 to 13,600 Btu/kWh (24.0\%-25.1\% thermal efficiency, HHV basis).

\section{Environmental Performance}

No mention was made of any difficulties in complying with the plant's environmental permit requirements.

\section{Economic Information}

The plant owner receives a capacity payment from Virginia Power that keeps the plant ready to run. During operation, additional payments for fuel and O\&M are received. These are currently about $2.0 \phi / \mathrm{kWh}$ for fuel and $0.5 \phi / \mathrm{kWh}$ for O\&M. (At a heat rate of about $14,000 \mathrm{Btu} / \mathrm{kWh}, 2.0 \phi / \mathrm{kWh}$ is equivalent to $\$ 1.43 / \mathrm{MBtu}$. Assuming a wood heating value of $8,500 \mathrm{Btu} / \mathrm{lb}$ on a dry basis, this is equivalent to about $\$ 24 /$ dry ton of wood. Assuming an average wood moisture content of $50 \%$, this is equivalent to about $\$ 12 / t$ of wood.)

\section{Lessons Learned}

No mention was made of any major problems or surprises encountered during 4 years of operation. Some minor technical problems or issues were mentioned (most of which are typical of biomass power plants):

- Fuel feeding problems in the early days of operation, quickly corrected.

- Erosion and corrosion in the fuel splitter boxes and conveyor belt shrouds (corrected by replacing the original 3/4-in. steel plate with 1/4-in. steel lined with $1 / 2$ inch of a plastic material).

- Occasional heating and combustion problems in the fuel pile.

- Occasional odor problems until they learned not to let any part of the pile age longer than a year. (The maximum fuel storage time is much shorter than 1 year now.)

There was a major turbine trip on Christmas day 1996, caused by an electrical short circuit. $\mathrm{ABB}$ had to make a replacement part in Sweden, and the plant general manager personally took it through customs in Washington, DC, and drove it to the plant in time to be back on line as scheduled.

The Multitrade project is an interesting example of a biomass plant that was designed from the beginning to be a peaking plant. (Many other biomass plants that now operate as peaking plants were originally designed and contracted as baseload units.) The fuel cost for this rural plant, about $2 \varnothing / \mathrm{kWh}$, is high compared to that for an urban wood waste plant such as Ridge Generating Station, about $0 \notin / \mathrm{kWh}$. It would be interesting to see how the 
cost of the Multitrade contract to Virginia Power would compare to the cost of an $80 \mathrm{MW}$ natural gas-fired peaking plant in the same location.

\section{Sources and Contacts}

Most of the information in this section was obtained from Tom Corlett, plant general manager (reassigned to another office in 1998). An article in the SERBEP Update, August 1994, also provided information.

Carl Levesque

plant manager

Multitrade Project, P.O. Box 2001

Hurt, VA 24563

Phone: 804-324-8223 Fax: 804-324-8228 


\section{RIDGE GENERATING STATION, AUBURNDALE, FLORIDA}

The Ridge Generating Station Limited Partnership owns an independent power-producing unit between Auburndale and Lakeland, Florida, that burns waste wood, waste tires, and landfill gas. The unit has a gross capacity of $45 \mathrm{MW}$ and nets about $40 \mathrm{MW}$ in sales to Florida Power Corporation. Generally, the plant operates at full capacity from 11:00 a.m. to 10:00 p.m., and reduces load at night. Wheelabrator Ridge Energy, Inc., a division of Wheelabrator Environmental Systems, Inc., operates the plant under contract to the owner.

Vital Statistics

\begin{tabular}{lll}
\hline Design capacity, net MWe & 40 \\
Configuration & 1 traveling grate stoker boiler \\
Operating cycle (typical): & Full load 11:00 am - 10:00 pm \\
& Reduced load 10:00 pm - 11:00 am \\
& & \\
\hline Fuels, \% by heat input: & Urban wood wastes & $\sim 66$ \\
& Scrap tires & $\sim 30$ \\
& Landfill gas & $\sim 4$ \\
Net heat rate, Btu/kWh & $\sim 16,000$ \\
Thermal efficiency, HHV, \% & $\sim 21$ \\
Net generation, $\mathrm{MWh} / \mathrm{yr}$ & $\sim 200,000$ \\
\hline
\end{tabular}

\section{History and Outlook}

Because of its low-lying geography and high water table, Florida has a stronger incentive than most states to find alternatives to landfilling solid wastes. Landfills that begin at ground level and rise as high as $200 \mathrm{ft}$ are commonly the highest elevations in Florida coastal counties. State legislation and incentive programs since the 1970s have caused Florida to have the largest capacity of waste-to-energy (WTE) facilities of any state. Not counting Ridge Generating Station, there are 12 WTE plants in Florida with a combined capacity of $486 \mathrm{MW}$. (Four are operated by Wheelabrator.) Because of its climate, Florida also has a relatively high per-capita generation rate of urban wood wastes.

The initial development of the Ridge Generating project by Decker Energy-Ridge Inc. and Wheelabrator Polk Inc. (the general partners in Ridge Generating Station Limited Partnership) involved discussions with Polk County about a WTE plant. However, Polk County had ample landfill space available, so the project was redefined to use only selected portions of the solid waste stream as fuel-urban wood wastes and scrap tires, along with landfill gas from a Polk County landfill adjacent to the 31.4-acre plant site. The project 
developers signed a Power Sales Agreement with Florida Power Corporation in March 1991; construction began in late 1992, and the plant came online in August 1994.

The contract with Florida Power Corporation was renegotiated after the plant began operation. It now requires the plant to generate electricity during peak hours only. Generally, the plant operates at full capacity from 11:00 a.m. to 10:00 p.m. 7 days a week and reduces load at night.

Ridge Generating has been peripherally involved in a research project by the University of Florida and others, to evaluate the production of sugarcane on reclaimed phosphate mine areas south of the plant. Juice from the cane would be used to produce ethanol, and the processed cane bagasse would be added to the fuel mix at the power plant. Based on the feasibility studies to date, the ethanol project does not appear to be economically attractive.

\section{Plant Flowsheet and Design Information}

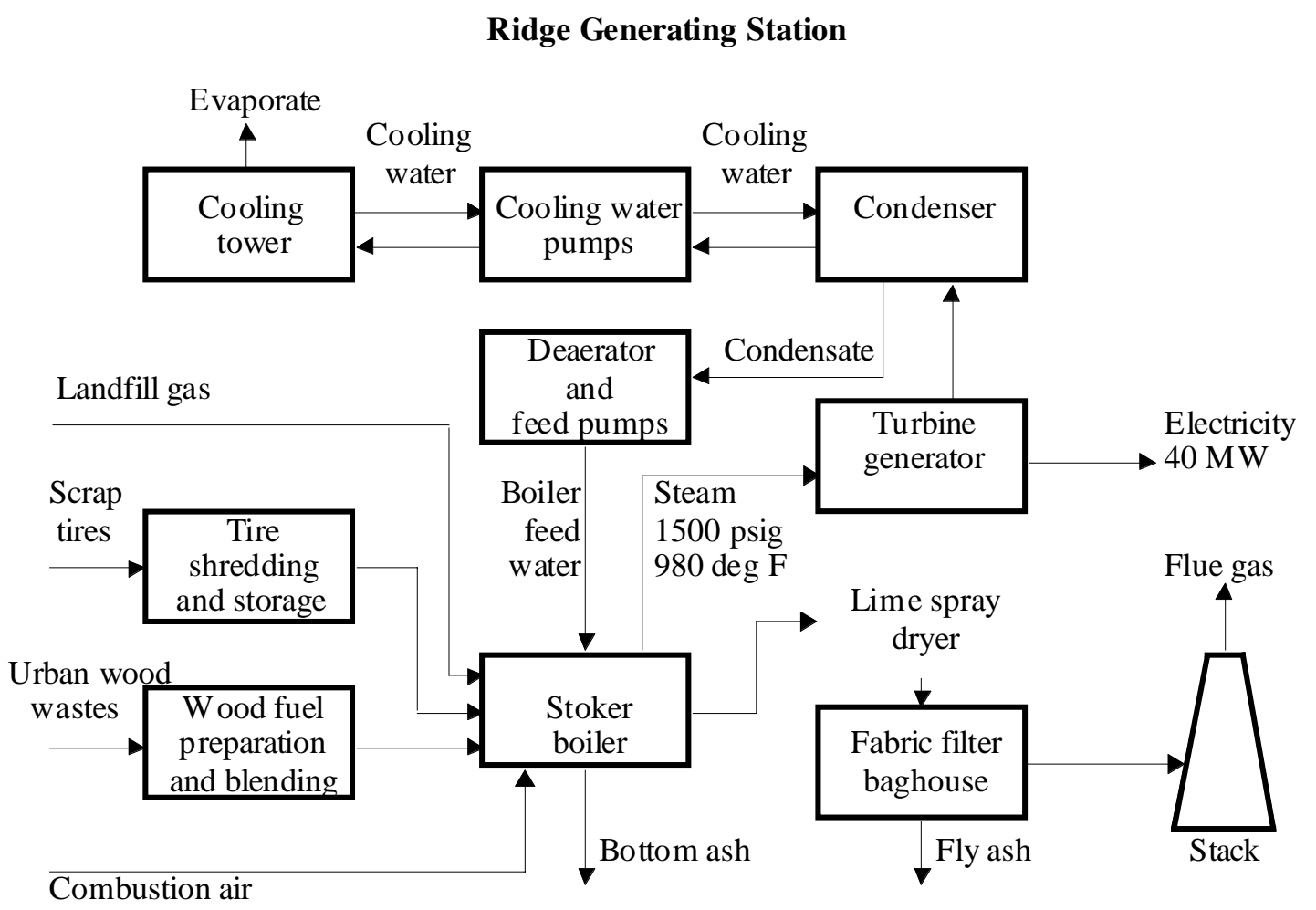

The plant processes about $250,000 \mathrm{t} / \mathrm{yr}$ of wood wastes and $35,000 \mathrm{t} / \mathrm{yr}$ of scrap tires. The landfill gas provides about $3 \%-5 \%$ of the heat input to the system, which includes a Zurn traveling grate boiler, a turbine generator, and a lime slurry spray dryer/baghouse system plus a noncatalytic $\mathrm{NO}_{\mathrm{x}}$ reduction system to control air pollutants from the combustion process. The facility operates with zero water discharge and uses cooling towers for its cooling system. Fresh water makeup comes from a deep well. 


\section{Boiler}

The Zurn traveling grate boiler generates about $345,000 \mathrm{lb} / \mathrm{h}$ of steam at about $1500 \mathrm{psig}$ and $980^{\circ} \mathrm{F}$. Wood typically provides about two-thirds of the total heat input; TDF provides about 30\%; and landfill gas provides about 3\%-5\%. Wood is injected to the boiler about $2 \mathrm{ft}$ above the grate; TDF about $2 \mathrm{ft}$ above the wood; and landfill gas enters about halfway up the furnace.

\section{Fuel Systems}

The plant has three separate fuel systems. The wood waste fuel yard takes up the most space and has the most equipment. Vehicles of varying types and sizes enter the fuel yard and discharge their wood wastes as directed. Two truck dumps allow large vans carrying wood chips to be dumped into below-grade collection areas from which the wood chips are fed into the processing and storage system. Other wood wastes trees, brush, yard waste, pallets, industrial wood scraps, construction wood scraps, demolition wood debris, etc. are dumped out onto the ground. The plant accepts all types of wood wastes, including treated wood. The only type not accepted is palm trees, which are too fibrous and cause problems during processing.

Dozers and bucket trucks feed the large-sized wood wastes into a large tub grinder, which operates mostly at night. The tub grinding operation is run by a contractor. Wood waste from the tub grinder and from the truck dumps is placed on a conveyor and fed to a vertical hog. It then passes under a magnet and through a screen. Overs go to a second vertical hog and under another magnet. From this point the fuel is conveyed to a reclaimer/stacker which distributes the fuel onto the storage pile. The typical residence time in the storage pile is about 3 months. The wood wastes are effectively blended and are prepared and stored.

Vehicles carrying scrap tires to the plant are directed to the tire area, which is between the wood fuel yard and the boiler. A tire shredding machine produces approximately 3 -in. tire chips, which are conveyed onto a storage pile. Loaders place the TDF onto a conveyor that takes it to the boiler.

The Polk County Landfill "across the fence" has a grid of gas wells, a gathering system, and a pipeline that carries the landfill gas to the plant. The gas is piped directly into the furnace.

\section{Emissions Control}

The combination of waste fuels used by the Ridge Generating plant requires an effective scrubbing system to remove $\mathrm{SO}_{2}$ (tires have significant as do some types of wood waste such as $\mathrm{C} / \mathrm{D}$ ) and other trace contaminants. A spray dryer lime scrubber, followed by a fabric filter baghouse, perform this function while removing fly ash from the flue gas. An $\mathrm{NH}_{3}$ injection system reduces $\mathrm{NO}_{x}$ emissions.

\section{Staffing}

The plant is staffed by about 40 people, with about 7 operating staff per shift and the remainder on day maintenance and office administration. 


\section{Fuels}

The facility receives waste wood and tires from local haulers and communities within about a 50-mi radius. (Tampa and parts of Orlando are within this radius.) About $20 \%$ of the wood wastes and all the tires come in with tipping fees. The rest of the wood wastes are obtained at very low cost. The waste wood includes a great deal of vegetative waste, which has a high moisture content. Varying moisture content is one of the major control problems, but using tires and landfill gas helps control the combustion process. The generating station paid for the landfill gas wells, gathering system, and pipeline from the landfill to the plant, but does not pay a fee for the gas. The station does pay to place ash from the combustion process back into the landfill.

The total annual wood consumption at the plant is about $250,000 \mathrm{t} / \mathrm{yr}$, of which an estimated one-third, or about 80,000 t/yr, come from the Lakeland-Winter Haven metropolitan area (population 410,000 ). Lakeland is about midway between the much larger metropolitan areas of Tampa and Orlando, which sprawl from about 40 to $70 \mathrm{mi}$ from the plant. Most urban wood waste fuel is tree wastes, brought to the plant by tree service companies and land clearing companies. About $10 \%-15 \%$ of the total wood waste is C/D wood debris; industrial wood wastes such as pallets and scraps account for a smaller percentage.

\section{Operating Experience}

The plant has operated well, although it has experienced some of the typical problems with boiler tube fouling, etc., caused by the use of waste fuels containing alkali, chlorine, sulfur, and other contaminants. Plant personnel mentioned no major equipment problems and seemed happy with the system's ability to efficiently handle the three fuels.

\section{Environmental Performance}

No difficulties were reported in meeting the air quality permit requirements. A very slight haze was visible in the plume leaving the plant's stack, which is typical of plants that use $\mathrm{NH}_{3}$ injection for $\mathrm{NO}_{\mathrm{x}}$ control. In July 1996 the plant obtained approval to reuse its ash in asphalt or concrete mixtures; treatment methods to allow the ash to be marketed in this way are being evaluated. Presently, ash is disposed of in the landfill.

\section{Economic Information}

Detailed economic information was not provided. The power sales agreement with the utility is an arms-length transaction for peaking power. To generate a profit on the plant's operation, Wheelabrator Ridge Energy must obtain net revenues from the tipping fees it charges for wood wastes and scrap tires, and must hold its O\&M costs to an absolute minimum.

Tipping fees charged by the plant for wood wastes are quite low- $\$ 5 / \mathrm{t}$ for wastes that require a minimum of processing and $\$ 12.50 /$ t for more difficult-to-process wood wastes. For comparison, Polk County owns and operates two class 1 landfills and one C/D landfill (which send about 41,000 t/yr of brush to the Ridge Generating plant). The Polk County landfills charge tipping fees of $\$ 44 / t$ for household garbage and $\$ 25 / \mathrm{t}$ for yard waste or $\mathrm{C} / \mathrm{D}$ debris. The BFI Cedar Trails Landfill in Polk County receives mostly C/D debris (and sends about $10,000 \mathrm{t} / \mathrm{yr}$ of clean wood waste to the Ridge Generating plant). The BFI landfill tipping fees are \$15/t for C/D debris and \$18/t for yard waste. These data indicate 
that the Ridge Energy plant sets its tipping fees significantly lower than the landfill tipping fees in the area to attract wood wastes. The tipping fees of $\$ 5 / \mathrm{t}$ and $\$ 12.50 / \mathrm{t}$ are probably very close to the actual cost of grinding, screening, and blending the wood wastes in Ridge Energy's fuel yard. The plant purchases no wood fuel, although it does pay the transport cost for some wood waste suppliers within a 50-mi radius.

The $\$ 60 /$ tipping fee charged for scrap tires probably provides the plant a significant net revenue stream. The tire shredding system at the plant is a fairly simply one, producing approximately 3-in. pieces, with no wire removal.

Overall, the net fuel cost must be very close to $\$ 0 / \mathrm{MBtu}$ as the three fuels enter the boiler.

\section{Lessons Learned}

The contractual and business arrangements used by the Ridge Generating Station provide a good example of a likely niche for biomass power: an urban wood waste recycling operation. The primary product is electric energy, marketed to the utility (or in the future, to the power exchange) mostly during peak hours. Urban wood wastes constitute the primary, but not necessarily the only fuel. Other opportunity fuels (tires and landfill gas at Ridge; petroleum coke, waste oil, and asphalt shingles at other plants) can provide higher tipping fees and have HHVs. Depending on regulatory definitions and market prices, the fuel mix might be controlled so the electricity will qualify as green power and command a premium price.

The important concept illustrated by Ridge Generating Station is that of a waste recycling facility, versus the concept of a power plant buying biomass fuel. The fuel manager does not buy BDT of fuel under long-term contracts and does not force suppliers to meet strict fuel quality specifications. He works within the local and regional waste management infrastructure to provide a low-cost recycling service to waste generators, and to provide a free or negative-cost fuel mix to the plant for energy production.

To operate this way, a plant must be designed for maximum fuel flexibility. This includes the plant's fuel processing and feeding systems, combustion system, air quality permit, and emissions control systems. The Ridge fuel yard can handle essentially any type or size of wood waste; its only restriction is that it will not accept palm trees. The simple and reliable traveling grate stoker boiler can burn these mixed wood wastes, including yard wastes, and can burn crude TDF and landfill gas. This combustion system, unlike other good candidates such as fluidized beds, does not require more expensive processing to remove wire from TDF. The emission control system with $\mathrm{NH}_{3}$ injection for $\mathrm{NO}_{x}$ control and a lime spray dryer and baghouse can remove almost any significant pollutant in these wastes. In the future including a selective catalytic reduction unit for really low $\mathrm{NO}_{\mathrm{x}}$ emissions may become standard, especially in large urban areas where these types of biomass plants will be most useful and economical.

Another key to success for an urban wood waste power plant is location. Ridge has some pluses and minuses in this regard. Two negatives are the 40-70 mi distance from really large metropolitan areas, and the lack of direct freeway access to the plant site. The location next to a landfill is a positive for several reasons: the landfill gas, the relatively easy permitting, and the fact that waste hauling trucks were already commonplace on the local roads. Finding suitable sites and obtaining permits for similar plants in the immediate 
Tampa or Orlando areas might be significantly more difficult. If it could be done, however, the net revenue opportunities from waste fuels would be improved.

\section{Sources and Contacts}

Phil Tuohy, the plant's fuel manager, provided most of the information in this section. A brief description of the plant was contained in the SERBEP Update newsletter for August 1997. Information on Florida's WTE industry was obtained from Solid Waste Management in Florida, June 1998, an annual report published by the Florida Bureau of Solid and Hazardous Waste. Information on urban wood wastes in the Lakeland-Winter Haven metropolitan area was collected by the author as part of a study on urban wood wastes around the United States.

Phil Tuohy

Fuel Procurement Manager

Wheelabrator Ridge Energy Inc.

$3131 \mathrm{~K}$-ville Avenue

Auburndale, FL 33823

Phone: 941-665-2255, ext. 112

Fax: 941-665-0400 


\section{GREENIDGE STATION (COFIRING), DRESDEN, NEW YORK}

New York State Electric and Gas (NYSEG) began a cofiring test program at the Greenidge Station in 1994, using a separate wood fuel feed system to size and feed wood wastes to a PC boiler. The tests were successful and economics looked promising, so NYSEG began cofiring wood on a sustained, commercial basis at the end of 1997. During 1998, the 108-MW coal-fired boiler (Unit 4) consumed about 11,000 t of wood wastes, which provided about $5 \%$ of the boiler's heat input. A new hammermill will be installed in early 1999, to allow the level of cofiring to be maintained at $10 \%$ of boiler heat input. This will be equivalent to about 11 MW from wood wastes. In March 1999, the plant will have a new owner, AES Corporation, which won a bid in August 1998 to acquire all six of NYSEG's coal-fired plants in New York.

\begin{tabular}{|c|c|c|c|}
\hline \multicolumn{4}{|c|}{ Vital Statistics } \\
\hline \multirow[t]{2}{*}{ Configuration } & \multicolumn{3}{|c|}{ Tangentially fired PC boiler } \\
\hline & Wood & Coal & Total \\
\hline Design capacity, net MWe & 10.8 & $97.2 *$ & 108 \\
\hline Fuels, $\%$ by heat input & 10 & 90 & 100 \\
\hline Net heat rate, Btu/kWh & 11,000 & 9,818 & 9,936 \\
\hline Thermal efficiency, HHV, \% & 31.0 & 34.8 & 34.3 \\
\hline
\end{tabular}

*108 MW when not cofiring wood.

\section{History and Outlook}

NYSEG's cofiring work at the PC unit at Greenidge Station was initiated after the company obtained positive results at some older stoker boilers. Greenidge Station in Dresden, New York, is on the western shore of Seneca Lake. This is in the center of New York, surrounded by farms, forests, vineyards, and orchards. The $108 \mathrm{MW}$ Unit 4 came on line in 1953. (Units 1 and 2 are retired and Unit 3 was brought back on line from reserve standby in July 1998.) The relatively small plant size (for a PC boiler), the upgraded electronic boiler controls, and continuous emissions monitoring systems made Unit 4 ideally suited for testing and research.

The wood fuel feed system was installed and ready to receive fuel by mid-October 1994 . On October 25, a test burn was started using the separate fuel feed system. On October 27, after some mechanical and electrical changes were made, the system functioned very well. An even and constant fuel feed was obtained and steady combustion results were observed. 
Several more years of testing and demonstration followed. By late 1997, the wood cofiring system was running routinely. Most of the original test equipment had been replaced with more permanent equipment, although the hammermill was an antiquated unit, designed for $3 \mathrm{t} / \mathrm{h}$ but operating at 7-8 t/h. The plant consumed 11,120 t/yr of wood wastes in 1998, and produced about 5-6 MW. A new $15 \mathrm{t} / \mathrm{h}$ hammermill will be installed in 1999, allowing the plant to run with about $10 \%$ heat input from wood fuel.

As summarized by Wally Benjamin, the NYSEG engineer who supervised the test program, "The Greenidge plant receives wood residues from a variety of wood processing industries, including furniture manufacturers. The plant burns 600 to 1200 tons of wood per month, which allows the plant to produce 5 to $10 \mathrm{MW}$, or 5 to 10 percent, of its power from wood. The fuel arrives at 2 to 3 inches maximum size and is ground at the plant to less than 1/4 inch. Moisture levels vary from 10 to 40 percent, creating Btu levels from 4500 to 8000 Btu/pound."

\section{Plant Flowsheet and Design Information}

\section{Greenidge Station}

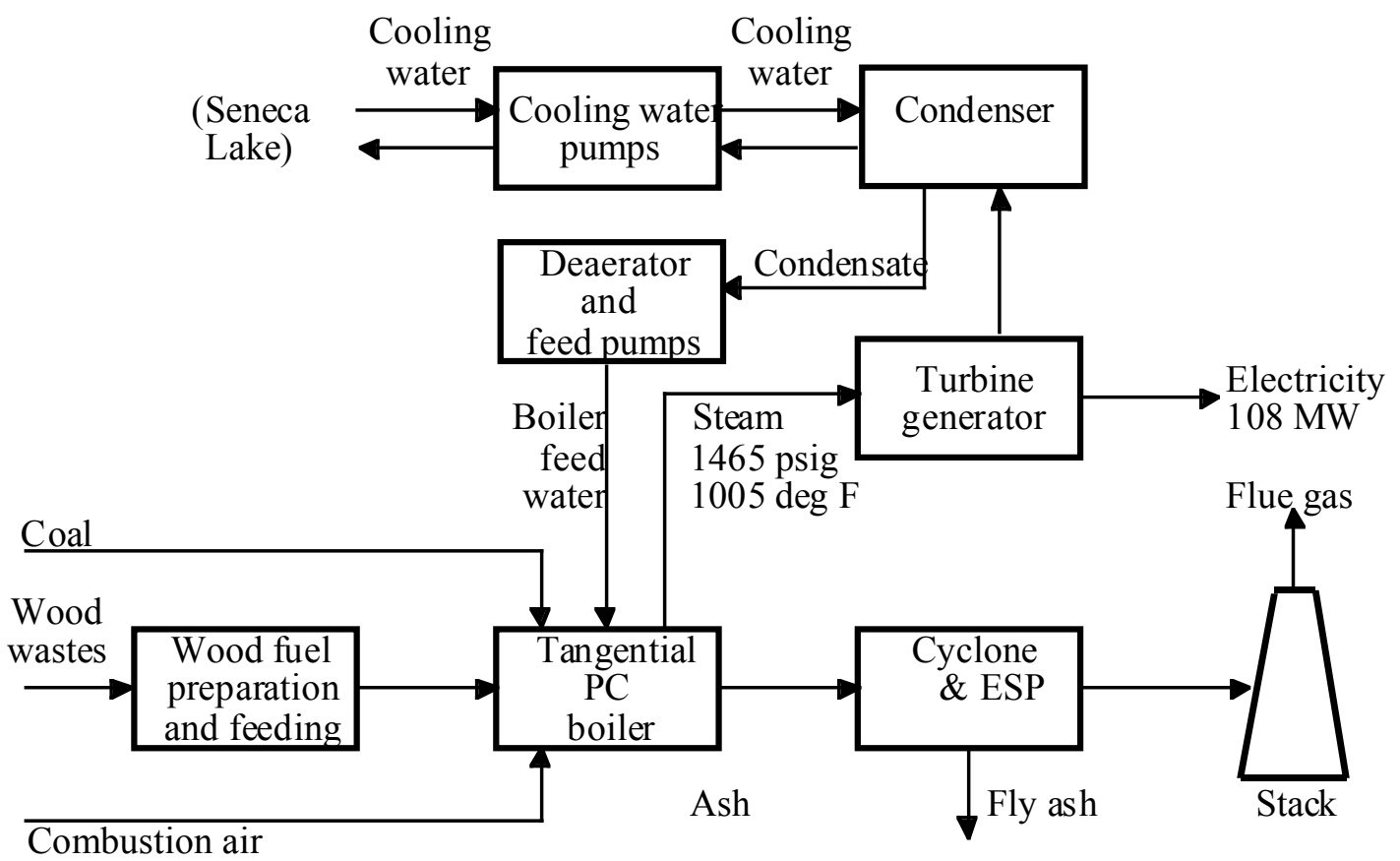


Boiler

The Combustion Engineering tangentially fired boiler is rated at $665,000 \mathrm{lb} / \mathrm{h}$ of steam at 1465 psig and $1005^{\circ} \mathrm{F}$.

\section{Boiler Modifications for Cofiring}

Designs for retrofitting the plant to cofire biomass were based on the boiler receiving, via a separate fuel feed system, wood products reduced to a top size of $1 / 8$ in. for burning in suspension. This method was selected because other utility experience with mixing wood with coal and then reducing its size in the pulverizers showed that, at $5 \%$ wood or more by weight, the mills lose efficiency, which affects the coal sizing. Other advantages to using the separate fuel feeding system are the ability to quickly change the blend of alternative fuel being fired to match various operational needs, and that it can be designed to feed wood at much higher rates than could be fed through a coal pulverizer.

The boiler can maintain full load with one burner out of service. Therefore, a burner port was chosen as the best test option for installing a separate fuel feed system. Removing a coal burner and installing the wood fuel pipe took no more than $2 \mathrm{~h}$ with essentially no impact on the boiler. A slide gate shutoff valve isolated the wood fuel system from the boiler combustion when the wood fuel system was not in operation.

Wood Fuel System

The system installed for initial testing had a capacity of $7.5 \mathrm{t} / \mathrm{h}$ of wood waste fuel. The fuel could be fed to the first screw conveyor via loader or walking floor truck trailer. A 2-in. screen over the No. 1 screen limited oversized material from the system. The No. 1 screw controlled the fuel feed rate via a variable speed controller. Conveyor 1 fed the constant speed screw conveyor 2 . Screw conveyor 2 discharged to a rotary airlock feeder. The airlock fed the fuel to the pressurized 6-in. fuel transport line. The fuel transport line (running at 3 to $5 \mathrm{psig}$ ) moved the fuel to burner 2 in the northwest corner of the boiler. The velocity in the transport system is approximately $100 \mathrm{ft} / \mathrm{s}$; it is powered by a $50 \mathrm{hp}$ blower moving $1450 \mathrm{cfm}$.

\section{Emissions Control}

The plant has an ESP for fly ash removal.

\section{Fuels}

The fuel sources used for initial testing come from the sawmill industry. The sawdust was delivered on walking floor trucks in loads of 15-23 t. The trucks were unloaded directly to the fuel feed hopper. There is some competition for sawdust because dairy farms use it for bedding and pellet fuel manufacturers use it to fuel pellet wood stoves.

The hardwood market in New York State escalated during the late 1990s, with an increasing price structure. One local lumber company expanded the production of one of its sawmills from 7 million to 15 million board $\mathrm{ft} / \mathrm{yr}$. This company supplied the fuel for the initial test program at Greenidge Station, and expressed very strong interest in supplying sawdust to the Greenidge Station at a cost of $\$ 10 / \mathrm{t}(\$ 0.92-1.00 / \mathrm{MBtu})$. A fuel survey by NYSEG staff found 30,000-45,000 t/yr of wood wastes available in the local area from furniture manufacturers and lumber mills. The New York State DEC forestry section 
estimated that $632,000 \mathrm{t} / \mathrm{yr}$ of sawmill residue are generated within a 50-mi radius of Greenidge Station.

Large lumber producers and furniture manufacturers expressed the desire for a steady long-term outlet for their wood wastes. They are also motivated by a desire to find an environmentally sound method of waste disposal. In early 1999, nearly all the plant's wood supply was coming from two furniture manufacturers.

Greenidge Station has tested small quantities of willow chips obtained from the State University of New York College of Environmental Science and Forestry plantation in Tully, New York.

\section{Impact of Cofiring on Plant Efficiency}

The net plant heat rate when the boiler is running on $100 \%$ coal was measured at 9818 $\mathrm{Btu} / \mathrm{kWh}$ in 1994 . Calculations indicated that at $10 \%$ cofiring, the plant heat rate would increase by about $1 \%-1.5 \%$. This would increase the heat rate for the wood/coal blend to 9916-9965 Btu/kWh, and would mean that the heat rate for the wood fuel alone would be about 10,800-11,300 Btu/kWh.

\section{Operating Experience}

Initial testing proceeded with little or no difficulty. However, a test with green wood (white oak) sawdust was terminated after only $7 \mathrm{t}$ had been run because long, stringy pieces of wood bridged the burner deflectors. This caused excess pressure buildup in the wood fuel system. All other portions of the transport system handled this material very well. A 15-t load of kiln dried material transported and burned so well that $9 \mathrm{MW}$ of output were produced from the test system. After the initial tests, the protocol was revised so the system output was held at 90-92 MW by reducing coal input as wood fuel was fed to the boiler. The objective of holding constant output was to compare $\mathrm{SO}_{2}$ and $\mathrm{NO}_{\mathrm{x}}$ readings.

\section{Environmental Performance}

During all the testing at Greenidge, readings of $\mathrm{NO}_{\mathrm{x}}$ at the boiler control room continuous emissions monitor (CEM) indicated decreases of 0.2-0.6 t/d. The $\mathrm{SO}_{2}$ readings decreased from 798 to $750 \mathrm{ppm}(70 \mathrm{lb} / \mathrm{h})$.

The coal used at Greenidge Station during the 1994 test program had 1.48\%-1.64\% sulfur. The sulfur content of the wood waste burned was $0.01 \%-0.04 \%$. Calculations of potential $\mathrm{SO}_{2}$ reductions for a $10 \%$ heat input cofire indicate that $600 \mathrm{t}$ of $\mathrm{SO}_{2}$ can be saved per year, based on 200,000 t of fuel combusted at Greenidge Station with current coal quality.

Operation of the ESP was not affected by the addition of the wood fuel. Stack opacity remained at pre-test levels of $9 \%-14 \%$.

A significant environmental benefit of cofiring involves reducing $\mathrm{CO}_{2}$ emissions to mitigate greenhouse gas. On average, displacing $1 \mathrm{MW}$ of coal-fired generating capacity by biomass feedstock offsets about $6000 \mathrm{t} / \mathrm{yr}$ of $\mathrm{CO}_{2}$. Thus, when Greenidge Station reaches the $10 \%$ cofiring level as planned in 1999 , it will offset about $65,000 \mathrm{t} / \mathrm{yr}$ of $\mathrm{CO}_{2}$. 
During initial testing, the fly ash analysis for loss on ignition increased during wood cofiring to $3.1 \%-4.3 \%$, from a coal-only range of $2.8 \%-3.8 \%$. Samples of the fly ash were tested for concrete strength comparison and fineness. No apparent problems were identified; no adverse affects were seen in the fly ash that would make it unmarketable.

\section{Economic Information}

Based on the Greenidge experience, the retrofit of a PC unit will cost approximately $\$ 300$ $500 / \mathrm{kW}$. To justify cofiring projects on strictly economic grounds, the wood waste fuel must provide a large enough cost saving (per Btu) compared to coal to pay off this investment in a reasonable time.

Economic cases in the NYSERDA report (see references at end) had capital costs of $\$ 1.5$ million to $\$ 3.2$ million. Coal at $13,000 \mathrm{Btu} / \mathrm{lb}$ costs $\$ 36 / \mathrm{t}$, and wood at $5400 \mathrm{Btu} / \mathrm{lb}$ (35\% moisture) and $8500 \mathrm{Btu} / \mathrm{lb}$ (7\% moisture) costs $\$ 10 /$ ton. Project payback periods were 5-11 years.

The delivered fuel prices at Greenidge Station are equivalent to $\$ 1.38 / \mathrm{MBtu}$ for coal, and $\$ 0.59-\$ 0.93 / \mathrm{MBtu}$ for wood, depending on moisture content. The difference between the coal and wood prices is $\$ 0.45-\$ 0.79 / \mathrm{MBtu}$. This is a substantial difference, and indicates the likelihood of favorable economics for cofiring at Greenidge Station. EPRI studies indicate that for cofiring to be economical, biomass fuel must be delivered at a price $\$ 0.25$ \$0.40/MBtu below the price of coal.

\section{Lessons Learned}

The cofiring experience at Greenidge Station demonstrates that a separate fuel feed system can effectively feed wood wastes to a PC unit. The economics at this site are favorable, and the plant has continued to cofire wood and invest in system improvements since the testing began more than 4 years ago.

As stated by Wally Benjamin, NYSEG engineer: "The technology for wood waste size reduction and drying is available today; however, the energy required for the process is higher than desired. Processing and drying techniques need further economic evaluation, research and development. Fuel can be obtained with a 2-in. nominal size from whole tree chippers and wood processors. Grinders do not normally produce a product that has good flow characteristics. The wood fibers are sticky, stringy, and elongated when produced from a grinding operation. The fuel product needs to processed by equipment that produces a chip. A stoker or cyclone boiler can burn 2-in. chips with limited or no modifications. To burn a 2-in. chip in a pulverized coal unit is not possible without the addition of a grate system."

Testing at the Greenidge Station indicated that a wood product of less than 1/4-in. diameter is desired, and that the primary particle size distribution should be $1 / 8$ in.-1/16 in. 


\section{Sources and Contacts}

Most of the information in this section was obtained from two reports prepared by Wallace Benjamin, P.E., of NYSEG:

- "Building Biomass into the Utility Fuel Mix at NYSEG: System Conversion and Testing Results for Greenidge Station,” presented at BIOENERGY '96, Nashville, Tennessee, September 15-20, 1996.

- "Renewable Wood Fuel: Fuel Feed System for a Pulverized Coal Boiler," prepared for NYSERDA, January 1996.

Additional information was obtained from an article by Raymond Costello of the U.S. Department of Energy entitled "Biomass Cofiring Offers Cleaner Future for Coal Plants," in Power Engineering, January 1999. Updated information was obtained from Wally Benjamin and other NYSEG employees during a site visit in November 1997, and from plant manager Doug Roll and cofiring project manager Dick Bentley in February 1999.

Dick Bentley

cofiring project manager

Greenidge Station

590 Plant Road

P.O. Box 187

Dresden, NY 14441

Phone: 315-536-2359 ext. 211

Fax: 315-536-8545 


\section{CAMAS COGENERATION PLANT AT FORT JAMES CORPORATION PAPER MILL, CAMAS, WASHINGTON}

The Camas paper mill, on the north side of the Columbia River $15 \mathrm{mi}$ east of Portland, Oregon, has a cogeneration plant that consists of five boilers: three high-pressure recovery boilers burning black and red liquor, one hog fuel boiler burning wood residues, and one power boiler burning natural gas. Fort James Corporation owns the mill, provides the fuels to the boilers, and uses the steam that is extracted or exhausted from the steam turbine at three pressure levels. The hog fuel boiler is owned by NRG Energy, Inc., which acquired the boiler as part of its acquisition of Pacific Generation Company from PacifiCorp. The cogeneration plant operates at the level required to satisfy the mill's steam requirements (typically about $1,200,000 \mathrm{lb} / \mathrm{h}$ ), and PacifiCorp takes all the electricity generated (typically about 40-48 MW).

\begin{tabular}{|c|c|c|c|}
\hline \multicolumn{4}{|c|}{ Vital Statistics } \\
\hline Configuration - 5 boilers & $\begin{array}{l}\text { Kraft } 1 \\
\text { Magn } \\
\text { Nature } \\
\text { Hog fi }\end{array}$ & $\begin{array}{l}\text { overy (2) } \\
\text { te } \\
\text { gas } \\
\text { l/gas }\end{array}$ & $\begin{array}{r}1975,1990 \\
1971 \\
1963 \\
1992\end{array}$ \\
\hline $\begin{array}{l}\text { Steam production, } \mathrm{lb} / \mathrm{hr} \\
\text { Steam to mill, } \mathrm{lb} / \mathrm{h}\end{array}$ & & $\begin{array}{r}600 \text { psig } \\
150 \text { psig } \\
75 \text { psig } \\
40 \text { psig }\end{array}$ & $\begin{array}{r}1,200,000 \\
460,000 \\
210,000 \\
370,000\end{array}$ \\
\hline $\begin{array}{l}\text { Electricity to grid, MWe } \\
\text { Design capacity, net MWe }\end{array}$ & 1998: & $\begin{array}{c}\text { March } \\
47.5 \\
52.2 \\
\end{array}$ & $\begin{array}{l}\text { July } \\
38.5\end{array}$ \\
\hline
\end{tabular}

\section{History and Outlook}

The Camas mill, originally built by the Columbia River Paper Company starting in 1883, produced the first wood pulp manufactured in the Northwest United States in 1885. In 1910 the Crown Columbia Paper Company doubled the capacity of the mill to 4 million lb/yr. In 1913 the mill changed to electric power. In 1914 Crown Columbia merged with Willamette Paper to form Crown Willamette, the second largest papermaker in the world. In 1928 Crown Willamette merged with Zellerbach Paper to become Crown Zellerbach. A \$425 million modernization of the mill was completed from 1981 to 1984. In 1986 the mill became a subsidiary of James River Corporation of Richmond, Virginia. In 1992, James River and PacifiCorp completed a 3-year, \$80 million energy and recovery 
modernization designed to increase energy efficiencies and reduce emissions. This included the construction of the hog fuel boiler, which PacifiCorp owned. At that time, the mill did not have electric generating capability; it was a customer of PacifiCorp, buying approximately $70 \mathrm{MW}$ of electricity to power the mill.

In January 1993, PacifiCorp and James River announced a project to cogenerate electricity by installing a steam turbine/generator and associated equipment. Construction began in March 1994. The \$53 million plant was finished on time in 1995 and \$9 million under budget. James River managed the construction and operates the cogeneration plant. The electricity generated is measured and PacifiCorp pays James River for it in the form of a royalty for the steam.

In August 1997, James River Corporation merged with Fort Howard Corporation to form Fort James Corporation, the current owner of the Camas mill. In November 1997, NRG Energy, Inc., acquired Pacific Generation Company from PacifiCorp. This acquisition included the hog fuel boiler in the Camas mill, along with 11 other projects with a total capacity of $776 \mathrm{MW}$ in five states and Canada. NRG identifies the hog fuel boiler as the Camas Power facility, and describes it as a 25-MW facility that uses hog fuel and natural gas as fuels.

The current business arrangement is that Fort James Corporation owns the 185-acre paper mill and four of the five boilers in the mill's cogeneration plant. NRG Energy, Inc. owns the hog fuel boiler. The mill operates all the boilers, the turbine/generator, and the steam distribution system throughout the mill. The Magnefite boiler and the two Kraft Recovery boilers operate at the levels required to dispose of all the red and black liquor produced. They generate significant amounts of steam in the process, but not enough to satisfy the mill's total steam demand. The hog fuel boiler and the natural gas boiler operate at the levels required to fulfill the mill's steam requirements. All the boilers can burn natural gas, and all but the hog fuel boiler can burn bunker $\mathrm{C}$ fuel oil.

\section{Plant Flowsheet and Design Information}

The block flow diagram on page 137 shows the overall arrangement of the Camas mill cogeneration facilities. The flow rates of steam and the electricity production vary with process needs in the mill, and with the weather (generally higher during the winter than during the summer). The values shown on the diagram are rounded off from those observed during a visit to the plant on August 18, 1998.

To give an idea of the equivalent size of this facility, if all 1,200,000 lb/h of steam were being condensed in a turbine generator to produce only electricity, it would generate about $90 \mathrm{MW}$. The hog fuel boiler, if it were operating at its rated capacity of $220,000 \mathrm{lb} / \mathrm{h}$ of steam while firing $100 \%$ wood, would be able to generate about $17 \mathrm{MW}$. At the steam generation rate on the diagram $(140,000 \mathrm{lb} / \mathrm{h})$, the hog fuel boiler would generate about 11 MW if it were supplying a condensing turbine/generator producing only electricity.

In the Camas mill, none of the steam is condensed in the turbine generator. All the steam goes to process uses in the paper mill, and is condensed during or following those process uses. Steam is extracted from the turbine at 150 and 75 psig, and the remainder is exhausted from the backpressure turbine at $40 \mathrm{psig}$. The production of electricity, and the revenue it provides to the mill, is strictly a side benefit. Before the turbine/generator set was 
installed, the plant flowsheet looked nearly identical, with pressure letdown valves controlling the amounts of steam going to the 150, 75, and 40 psig levels instead of a backpressure turbine. Even with the low power costs in the Pacific Northwest, PacifiCorp and James River Corporation apparently projected an attractive rate of return on the investment in the turbine generator system when they planned the project in 1992.

\section{Camas Cogeneration Plant}

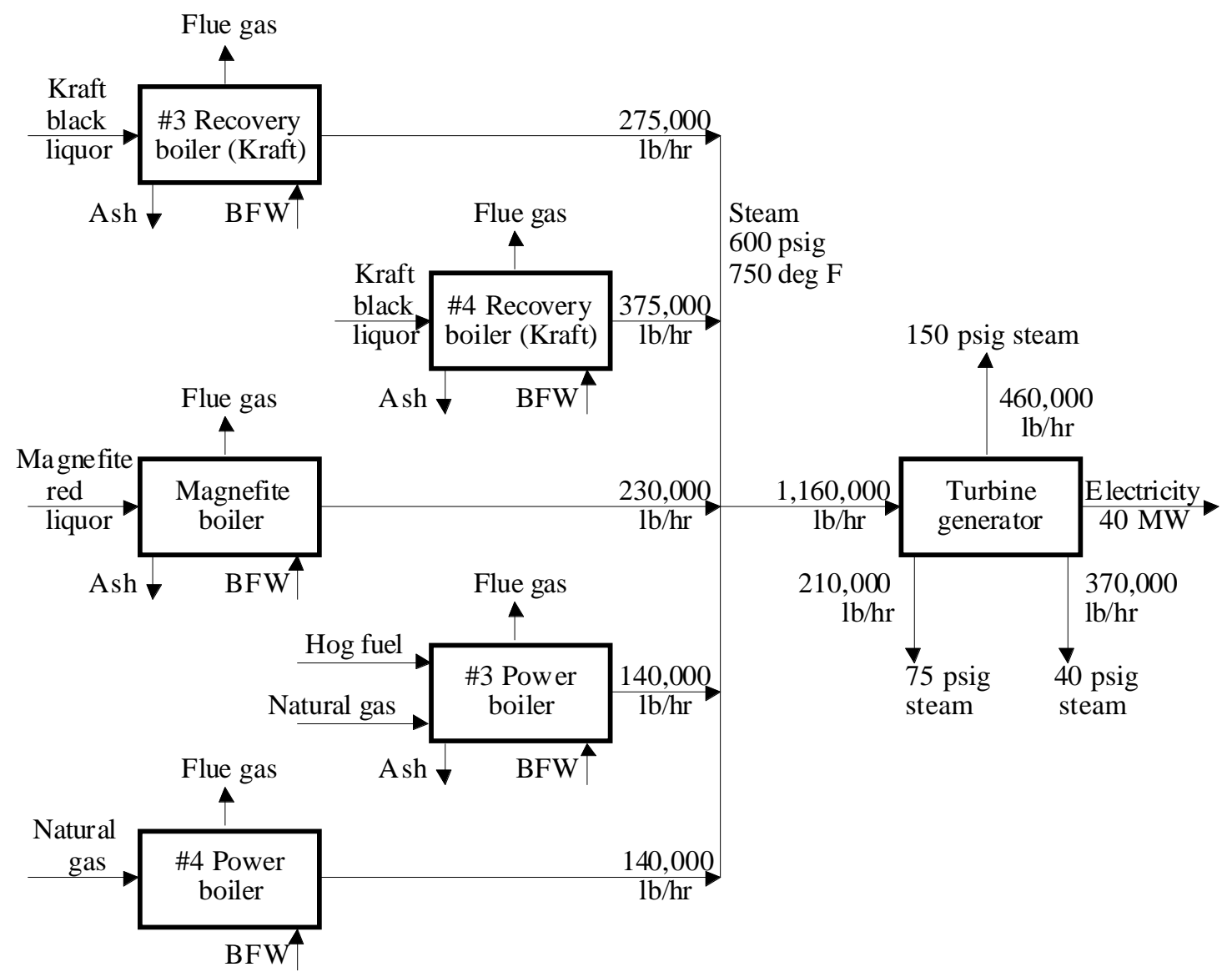




\section{Hog Fuel Boiler}

Foster Wheeler Corporation provided the hog fuel boiler, a single unit in which hog fuel is burned on a Detroit Hydrograte water-cooled vibrating grate ("shaker grate"). This grate spreads the fuel when it vibrates every minute or two, so small piles on the grate are leveled out. The fuel is mechanically distributed by screw feeders and moved gradually down the sloped grate to the rear of the furnace, where ash is discharged. The rated capacity of the boiler on $100 \%$ hog fuel is $220,000 \mathrm{lb} / \mathrm{h}$ of steam $\left(600 \mathrm{psig}, 750^{\circ} \mathrm{F}\right)$. When firing a combination of hog fuel and natural gas, the boiler can produce about $240,000 \mathrm{lb} / \mathrm{h}$.

A water-cooled vibrating grate has some advantages over a traveling grate that is cooled by the flow of primary combustion air through the grate:

- The grate has fewer moving parts and consequently requires less maintenance.

- Higher primary air temperatures are possible, allowing the use of higher-moisture fuels.

- Fuel/air ratio, as well as velocity, at the grate can be maintained at the optimum levels for control of $\mathrm{NO}_{\mathrm{x}}$ formation, carbon burnout, and particulate carryover.

Fly ash is separated from the flue gas leaving the boiler in a series of multiclone separators followed by an ESP. Combustion controls keep the $\mathrm{NO}_{\mathrm{x}}$ emissions well within permit levels without $\mathrm{NH}_{3}$ injection. Fly ash from the plant is used as a liming agent (soil amendment) on fields around the area.

\section{Fuel}

The fiber supply department, which buys the pulp chips for the mill, also buys hog fuel. The current market price for hog fuel in the Portland area is about $\$ 8 / \mathrm{dry}$ t. Trucks carrying hog fuel enter the mill property and drive to the hog fuel yard, where truck dumpers discharge the fuel. There is no screening, grinding, or other fuel preparation equipment in the hog fuel yard. Bulldozers with large blades manage the fuel piles. A long conveyor belt carries the hog fuel to the boiler building, where magnetic separators remove any metal contamination before the fuel enters the feed system to the furnace. The distance from the fuel yard to the hog fuel boiler is at least a mile.

\section{Turbine/Generator}

The steam turbine has two extraction levels (150 and 75 psig) and exhausts the remaining steam to the mill's 40-psig steam system. Its nominal rating for electricity production is 52.2 MW. The generator is a GE air-cooled unit that is rated higher than $52 \mathrm{MW}$ as a future consideration.

\section{Operating Experience}

The hog fuel boiler and turbine generator have run very reliably since they were started up. As in any industrial process plant, the steam supply must be available with high reliability, typically 330 or more $\mathrm{d} / \mathrm{yr}$. The redundancy inherent in the Camas cogeneration plant with five boilers, each capable of burning multiple fuels, enhances the overall reliability and flexibility of the system to meet operating demands.

\section{Environmental Performance}

No mention was made of any difficulties in controlling emissions to design limits or complying with permit requirements. 


\section{Economic Information}

No specific economic information was provided, except that a PacifiCorp press release in January 1996 mentioned that "the $\$ 53$ million plant was finished on time and $\$ 9$ million under budget." The press release did not state exactly what the scope of the "plant" was, but it is presumed to include the hog fuel boiler and the turbine/generator set. If the hog fuel boiler is considered equivalent to a $23-\mathrm{MW}$ plant as discussed earlier, $\$ 53$ million would be about $\$ 2,300 / \mathrm{kW}$.

In the visitor's lobby of the paper mill, a document entitled A Capsule History of James River's Camas Mill is available. It mentions that in 1992 "the mill completed a three-year, $\$ 80$ million energy and recovery modernization designed to increase energy efficiencies and reduce emissions." This may include the $\$ 53$ million referenced by PacifiCorp, but that is not certain.

Operating and maintenance costs for the hog fuel boiler are probably similar to costs for similarly sized stand-alone wood-fired plants, except that the paper mill can probably spread some of its O\&M, engineering, and management staff over a number of units or functions within the mill and achieve some economies. Hog fuel cost fluctuates with the market, but is probably now about $\$ 0.50 / \mathrm{MBtu}$.

Power costs in the Pacific Northwest are very low because of the predominance of hydroelectric generation, so the price PacifiCorp pays for the electricity from the plant (which is actually paid in the form of a royalty for the steam) is presumably quite low-probably about $1 \varnothing / \mathrm{kWh}$ or less. Still, this represents a significant cash flow to the paper mill. Assuming the mill generates about 300 million $\mathrm{kWh} / \mathrm{yr}$, and receives the equivalent of about $1 \notin / \mathrm{kWh}$ in royalty payments, the cash flow generated by the electricity is about $\$ 3$ million/yr.

\section{Lessons Learned}

The business arrangement used in this project may provide a useful model for future joint venture cogeneration projects involving electric utilities and paper mills. Although there have been several changes in ownership and company names because of mergers and divestitures during the short time the Camas cogeneration plant's business arrangement has been in place, there are really only two primary participants: the paper mill and the electric company. Each has its unique perspective, goals, and risk/reward scenarios.

The electric company undoubtedly regards the paper mill as a very important major customer, one that consumes about $70 \mathrm{MW}$ at a fairly steady rate year round. Assisting the paper mill with its cogeneration project is an important customer service provided by the utility; in return it receives a small amount of electricity (about $42 \mathrm{MW}$ on average) at a presumably low price. The greatest benefit from the cogeneration project to the utility is the increased likelihood that the paper mill will continue as a customer and not become a selfgenerator.

The paper mill is strictly interested in making paper products profitably. It is not in the energy business. Historically, the mill has bought electricity from the utility, and continues to do so. As deregulation and restructuring of the electric industry continue, at some point the mill may begin to shop around for the lowest-cost power. The mill's primary concern 
with its cogeneration plant is the reliable production of steam for process use. The utilityfinanced turbine/generator set provides the mill with an additional source of cash flow, without changing the steam generation and delivery system within the mill in any significant way.

This business arrangement appears to be sound for both parties. It is inherently stable and simple. It may not be the lowest-cost way for the mill to obtain electricity, but the cost is low enough and the supply is risk free. Lower-cost scenarios require the mill to go into the energy business, where it has little expertise or clout. The utility has added about $50 \mathrm{MW}$ of reliable generating capacity to its system for a relatively small investment, and has strengthened its relationship with a major customer.

\section{Sources and Contacts}

Gary Peterson and Todd Drenth of the Camas paper mill were very helpful in providing information and a tour of the facilities. Additional information was obtained from a "capsule history" of the mill, a PacifiCorp press release dated January 23, 1996, and a brief project description on the NRG Energy, Inc. Web site (www.nrgenergy.com).

Gary Peterson

Fort James Corporation

Camas Mill

Camas, Washington

Phone: $360-834-8352$

Fax: 360-834-8200 


\section{SNOHOMISH COUNTY PUD/KIMBERLY-CLARK CORP., EVERETT, WASHINGTON}

Snohomish County Public Utility District (PUD) (Snohomish) and Kimberly-Clark Corporation have a $43-\mathrm{MW}_{\mathrm{e}}$ cogeneration facility at Kimberly-Clark's paper mill in Everett, Washington. The cogeneration plant consists of a new wood waste-fired boiler that generates as much as $435,000 \mathrm{lb} / \mathrm{h}$ of steam and a recovery boiler that generates about $276,000 \mathrm{lb} / \mathrm{h}$ of steam. A new steam turbine extracts steam at the rates required to satisfy the mill's requirements (typically a total of about 500,000 lb/h of $300 \mathrm{psig}$ and $40 \mathrm{psig}$ steam), and a condenser condenses the remaining steam. The steam turbine drives an electric generator that generates an average of about 38.5 MW. Snohomish sells most of the electricity to the Sacramento Municipal Utility District (SMUD) under a 10-year contract.

\begin{tabular}{llr} 
& \multicolumn{3}{c}{ Vital Statistics } \\
\hline Boiler & Recovery boiler & Existing \\
& Wood waste boiler & New (1995) \\
& (Sloping grate) & \\
\hline Fuels: & Mill residues & \\
& Urban wood waste \\
\hline Steam production, lb/h & $(825$ psig) & 711,000 \\
Steam to mill, lb/h & $(300$ psig, 40 psig) & $490,000-$ \\
& & 560,000 \\
\hline Generation capacity, MWe & 47 & \\
Electricity to grid, MWe & $38.5 \mathrm{MW}$ average \\
\hline
\end{tabular}

\section{History and Outlook}

Scott Paper used to burn some of its wood waste in five, 60-year-old, inefficient boilers to provide process steam to its mill in Everett, Washington. Scott approached Snohomish to determine whether there was an interest in working together to install cogeneration along with boiler replacement. In October 1993 Snohomish and Scott agreed to install a turbinegenerator (rated capacities: extraction steam turbine, $46.9 \mathrm{MW}$; generator, $52.2 \mathrm{MW}$ ) and a modern 435,000 lb/h boiler. Scott built the cogeneration plant; Snohomish financed the capital costs (\$115 million), owns the plant, and receives the electrical output. KimberlyClark acquired Scott Paper Company in December 1995 just as the new cogeneration facility became operational. Kimberly-Clark operates and maintains the facility, pays for all the fuel for 15 years, and receives steam for the paper mill, which produces tissue, paper towels, and napkins. The cogeneration plant started initial operations in December 1995, and entered full commercial operation in August 1996. 
Snohomish contracted with SMUD to sell an average of about 33 MW through 2007. This was done to eliminate any early-year rate impacts on Snohomish County PUD customers. After the SMUD purchase period concludes, Snohomish intends to bring the power back to serve local customers. Under terms of the contract, SMUD will purchase energy and capacity at a levelized real rate of $4.1 \phi / \mathrm{kWh}$ through September 2007. The first year rate for energy was $3.3 \phi / \mathrm{kWh}$. The complicated PPA allows SMUD to purchase as much as 36 MW during summer and $26 \mathrm{MW}$ at other times of the year. SMUD has the option of storing a portion of the available winter capacity and energy and shaping it for summer delivery. Summer scheduling is capped at $42 \mathrm{MW}$.

The Kimberly-Clark Everett mill is a retail customer of Snohomish County PUD, and consumes nearly as much electricity as the cogeneration plant produces. On balance, there is typically a small export of about $5 \mathrm{MW}$ from the mill.

The sloping grate boiler was selected over more common stoker grate or fluidized bed designs for two primary reasons: (1) the ability of this mass burn type boiler to handle a wide range of fuel sizes, and thus eliminate the need for hogging and screening equipment; and (2) the guarantee offered by Gotaverken (later Kvaerner) of very low $\mathrm{NO}_{\mathrm{x}}$ emissions. Everett was in a nonattainment area for $\mathrm{NO}_{\mathrm{x}}$ at the time of permitting (it has since achieved attainment). The availability of mill residues has been decreasing in the area; urban wood wastes and land clearing debris are increasingly important components of the biomass fuel stream. The combustion air staging that was designed into the furnace in an attempt to reach the low $\mathrm{NO}_{\mathrm{x}}$ emissions created combustion problems that were ultimately solved by operating the boiler at higher $\mathrm{NO}_{\mathrm{x}}$ emissions than originally permitted, and modifying the older recovery boiler at the mill that brought the $\mathrm{NO}_{\mathrm{x}}$ emissions from the overall complex into compliance.

\section{Plant Flowsheet and Design Information}

\section{Boiler}

The boiler is a screw-fed, sloping grate design by Gotaverken (now Kvaerner), based on a mass burn design used in Europe and at a few locations in North America. At design conditions, the $435,000 \mathrm{lb} / \mathrm{h}$ of $825 \mathrm{psig}, 850^{\circ} \mathrm{F}$ steam from the wood-fired boiler is combined with $276,000 \mathrm{lb} / \mathrm{h}$ of high-pressure steam from the mill's recovery boiler burning waste liquor. The condensing steam turbine drives the generator and produces low-pressure steam (extracted at two pressure levels) for process use in the mill.

\section{Steam Turbine/Generator}

The GE extraction steam turbine has a rated capacity of $46.9 \mathrm{MW}$. Steam enters the turbine at about 800 psig and is extracted at 300 and 40 psig. The generator has a rated capacity of 52.2 MW. The condenser normally condenses $150,000-220,000 \mathrm{lb} / \mathrm{h}$ of exhaust steam from the turbine (the difference between the amount of steam generated in the two boilers and the amount of steam used in the mill). However, the condenser can condense 350,000 $\mathrm{lb} / \mathrm{h}$ of steam; this allows the wood-fired boiler to operate as a stand-alone power plant when the mill is down. The capacity of the wood-fired power plant when operating in a stand-alone electric generating mode is about $39 \mathrm{MW}$. 
Fuel System

The plant has a fuel receiving and storage system that can handle wood wastes in a range of sizes. Five groups of three screws each feed the wood wastes into the boiler.

\section{Snohomish County PUD/Kimberly-Clark Corp. Everett Cogeneration Plant}

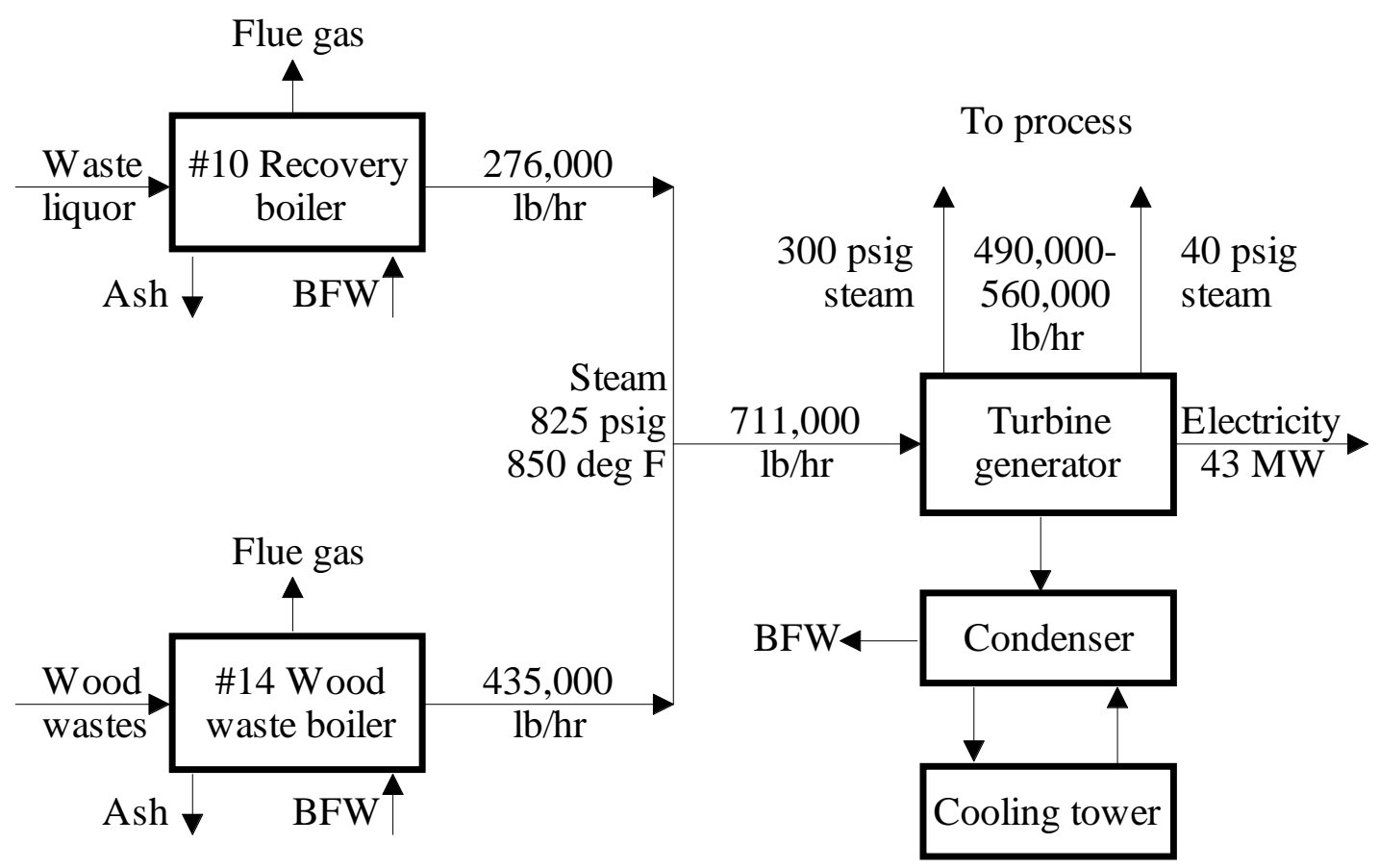

\section{Emissions Control}

$\mathrm{NO}_{x}$ was initially controlled by staged combustion and $\mathrm{NH}_{3}$ injection. After addressing the combustion problems in the unit and installing an $\mathrm{NH}_{3}$ injection system on the recovery boiler, the wood-fired unit is now operated with different air staging and no $\mathrm{NH}_{3}$ injection.

Particulate control is achieved by a baghouse that was installed about 20 years earlier to control particulate emissions from the old wood waste boilers. The baghouse was enlarged to provide a higher air-to-cloth ratio for the flue gas from the new boiler. 


\section{Fuels}

The fuel consists of: (1) mill residues, such as bark and hogged wood, supplied primarily by mills located in Puget Sound, Olympic Peninsula, and British Columbia; and (2) urban wood wastes such as pallets and land clearing debris. The urban wood waste, especially the land clearing debris, increases during the summer. The fuel mix has been running about $40 \%$ mill residue and $60 \%$ urban wood waste during the summer, and a greater proportion of mill residue during the winter. The long-term trend will be away from sawmill residues as logging is reduced in the region. Generally, the land clearing operators operate tub grinders at their sites and send the resulting fuel to the wood-fired plants in the area.

The plant has received permit authority to perform limited combustion trials on shredded railroad ties.

\section{Operating Experience}

The plant's electrical output was a little short of the contracted amounts during commissioning. The boiler could not meet the guarantees on $\mathrm{NO}_{\mathrm{x}}$ emissions and carbon carryover. Problems encountered during initial operations related primarily to the wide variation in fuel types, sizes, and moisture content, which were addressed by improved fuel blending in the yard, and by tinkering with the grate and with the feed systems. To comply with the very strict $\mathrm{NO}_{x}$ emission limit, excess amounts of $\mathrm{NH}_{3}$ were added to the flue gas at times, causing a visible plume. By increasing the secondary (overfire) air injection rate to increase turbulence, and by decreasing the $\mathrm{NH}_{3}$ injection rate, these problems were reduced.

The boiler can operate with $55 \%$ moisture fuel and generate $425,000 \mathrm{lb} / \mathrm{h}$ of steam, compared to the design values of $60 \%$ and $435,000 \mathrm{lb} / \mathrm{h}$. The operator keeps the fire line backed up on the grate, and burnout occurs on the lowest part of the grate. When $60 \%$ moisture fuel is received (during the rainy season, which typically peaks in January and February), the auxiliary burner (natural gas) must be used.

About 2 years were spent modeling the combustion process, making changes in the boiler, and working with the operating personnel, to adjust the systems and their controls so they would perform as specified. Changes were made in air nozzle locations, grate design, and other areas. The unit now performs well.

\section{Environmental Performance}

As discussed earlier, the unit could not meet the specified $\mathrm{NO}_{\mathrm{x}}$ levels, but its emissions are still low. The permit was amended to allow higher $\mathrm{NO}_{\mathrm{x}}$ emissions than originally specified, in return for installation of an $\mathrm{NH}_{3}$ injection system on the older recovery boiler at the mill to reduce $\mathrm{NO}_{\mathrm{x}}$ emissions from that unit. Ammonia injection into the flue gas at the wood-fired boiler was discontinued. The recovery boiler has a better profile than the wood-fired boiler, so the reduction of $\mathrm{NO}_{x}$ emissions by $\mathrm{NH}_{3}$ injection is much more efficient in that boiler. All permit requirements are being met.

\section{Economic Information}

During the first 15 years of operation, the paper mill buys the fuel, operates and maintains the facility, and uses the steam. The utility pays the capital cost (debt service) for the original plant plus any capital improvements, supplies power to the mill, and sells the electrical output to SMUD and its own customers. Starting in year 16, the utility will pay 
an increasing portion of the fuel cost. Starting in year 20, the utility will also pay part of the $\mathrm{O} \& \mathrm{M}$ cost.

The contract with SMUD for capacity and energy at a levelized real rate of $4.1 \phi / \mathrm{kWh}$ through September 2007 indicates that the cost of power from the cogeneration plant is relatively low for a wood-fired plant. Still, after 5 years of high rainfall and with deregulation working its way through the electric industry, wholesale rates for power in the Pacific Northwest have been much lower than $4 \notin / \mathrm{kWh}$.

\section{Lessons Learned}

The plant design anticipated the trend toward declining quantities of sawmill residues, and the increasing use of urban wood wastes in the region. Siting the plant at a paper mill provided an excellent fit for steam use, as well as expertise in wood waste handling and combustion. Wood-fired plants probably have to be cogeneration plants now to survive.

The design of the boiler did not live up to all its guarantees, but changes and compromises successfully resolved the problems. Both the paper mill and the utility appear to be happy with the project overall, and when asked, both said they would not have made different decisions on major equipment selections if they were doing it again.

In fairness, the apparent emphasis here on the problems encountered with the combustion system results mostly from the plants being in operation for only 2 years. Nearly all the plants in this report had some difficult learning experiences during their first year or two of operation. These initial difficulties usually fade into memories that seem less significant as the years pass and other challenges to the project arise.

\section{Sources and Contacts}

Robin Cross

Cogeneration Project Manager

Snohomish County Public Utility District

P.O. Box 1107

Everett, WA 98206

Phone: 425-258-8481

Fax: 425-258-8640

rhcross@snopud.com 


\section{OKEELANTA COGENERATION PLANT, SOUTH BAY, FLORIDA}

The Okeelanta Cogeneration Plant is a 74-MW biomass cogeneration project located next to the Flo-Sun Inc. Okeelanta Sugar Mill, 6 miles south of South Bay in Palm Beach County, Florida. U.S. Generating Co. (USGen) and Flo-Energy Corp. (an affiliate of FloSun Inc.) joined together to construct and operate the facility. It is the largest bagasse/biomass cogeneration plant in the United States. The plant provides process steam and power to the Okeelanta Sugar Mill and Florida Crystals Refinery, and sells its excess electricity to FPL. In 1997, the partnership filed bankruptcy and the plant shut down as a result of a contract dispute with the utility; the plant resumed operation in February 1998.

Vital Statistics

\begin{tabular}{ll}
\hline Design capacity, net MWe & 74.9 \\
Process steam to sugar mill & $1,320,000 \mathrm{lb} / \mathrm{h}$ \\
Configuration & 3 water cooled vibrating grate stoker boilers \\
\hline Fuels & Bagasse $(\sim 6 \mathrm{mo} / \mathrm{yr})$ \\
& Wood wastes (urban, land clearing, construction) \\
& Coal (boilers capable up to $40 \%)$ \\
\hline
\end{tabular}

\section{History and Outlook}

Flo-Sun, Inc. is a fully integrated sugar grower, producer, refiner, and marketer. In Florida, the company farms more than 180,000 acres of land and produces about 65,000 t/yr of sugar. Flo-Sun has a large sugar mill and refinery near South Bay, Florida, with old, small bagasse-fired boilers. A subsidiary, Flo-Energy, joined with USGEN to construct and operate the 74-MW Okeelanta Cogeneration Plant next to the Okeelanta Sugar Mill, burning bagasse and wood wastes.

Bechtel Power Corporation constructed the plant under a lump-sum turnkey contract with the Okeelanta Power Limited Partnership. USGen, through its affiliate, U.S. Operating Services Co., was responsible for plant O\&M. FPL contracted to buy the plant's electricity output for 30 years, and the Okeelanta Sugar Mill and Florida Crystals Refinery agreed to take the steam output. At the same time, similar arrangements were made to build the 52MW Osceola Cogeneration Plant next to the Osceola Farms Sugar Mill near Pahokee, Florida. The plants were financed, in part, through Palm Beach County Solid Waste Industrial Development Revenue Bonds, which were originally issued in an aggregate principal amount of \$160 million for Okeelanta and \$128.5 million for Osceola. 
In 1991, FPL entered into 30-year PPAs with Okeelanta and Osceola. The contracts provided that if the plants were not in commercial operation before January 1, 1997, FPL had no further obligation. FPL contended that the plants did not meet this deadline, and sued the Okeelanta and Osceola partnerships on January 8, 1997, to avoid its obligations.

On May 14, 1997, the partnerships that own the Okeelanta and Osceola plants filed for Chapter 11 bankruptcy protection after FPL terminated an agreement that had frozen the litigation. FPL's general counsel said the utility acted in the best interest of its customers, who, he said, were paying exorbitant prices to purchase electricity from the facilities. The plants, he said, were plagued with problems; they had had breakdowns and missed a January 1, 1997, deadline to become fully operational. He said the cost of purchasing electricity from the plants is " $80 \%$ to $100 \%$ more expensive than what we can get" from other power sources or by generating the electricity. A spokesman for the plants' owners said that FPL's description of the plants' costs were "grossly inaccurate and misleading." The partnerships vigorously contested FPL's claims.

On May 19, 1997, the Wall Street Journal reported that "several large mutual-fund companies are bracing for what could rank as one of the largest defaults in municipal-bond market history after two electricity generating plants filed for bankruptcy in Palm Beach County, Florida." According to the article, the default would be rivaled only by such municipal bond disasters as the default of the Washington Public Power Supply System in 1983, New York City in the mid-1970s, and the 1994 bankruptcy filing by Orange County, California.

On September 16, 1997, both plants were shut down and 96 employees laid off. FPL's planning documents show that Okeelanta had delivered 314,326 MWh to FPL up to that date in 1997, and that Osceola had delivered 251,066 MWh. For Okeelanta this represented about a $68 \%$ CF over the 8.5-mo period. In February 1998 the Okeelanta plant started up again, under an interim agreement with its bondholders. USGen remains a member of the partnership but chose not to continue as the plant operator. The plant is now operated by Flo-Energy. As of February 1999, the Osceola plant is still shut down. The bankruptcy proceedings for both plants are still ongoing.

The Okeelanta Cogeneration plant operates at the level of output required to satisfy the sugar mill's demands for steam and power. FPL no longer makes a capacity payment to the plant, and pays for the electricity that enters its system based on as available energy rates. 
The key events in the Okeelanta cogeneration project can be summarized as follows:

PPA signed

Financing completed

Construction started

Construction $30 \%$ complete

Construction $70 \%$ complete

Startup

Commercial operation

FPL sues to break contract

FPL terminates litigation standstill agreement

Okeelanta Power LP files bankruptcy

Plant shut down

U.S. Federal bankruptcy judge approves reorg. February 1998

plan allowing reopening one of the two plants

Okeelanta plant restarts commercial operation
1991

January 1994

1994

March 1995

May 1995

August 1996

January 1997

January 8, 1997

May 9, 1997

May 1997

September 16, 1997

February 1998

\section{Plant Flowsheet and Design Information}

\section{Okeelanta Cogeneration Plant}

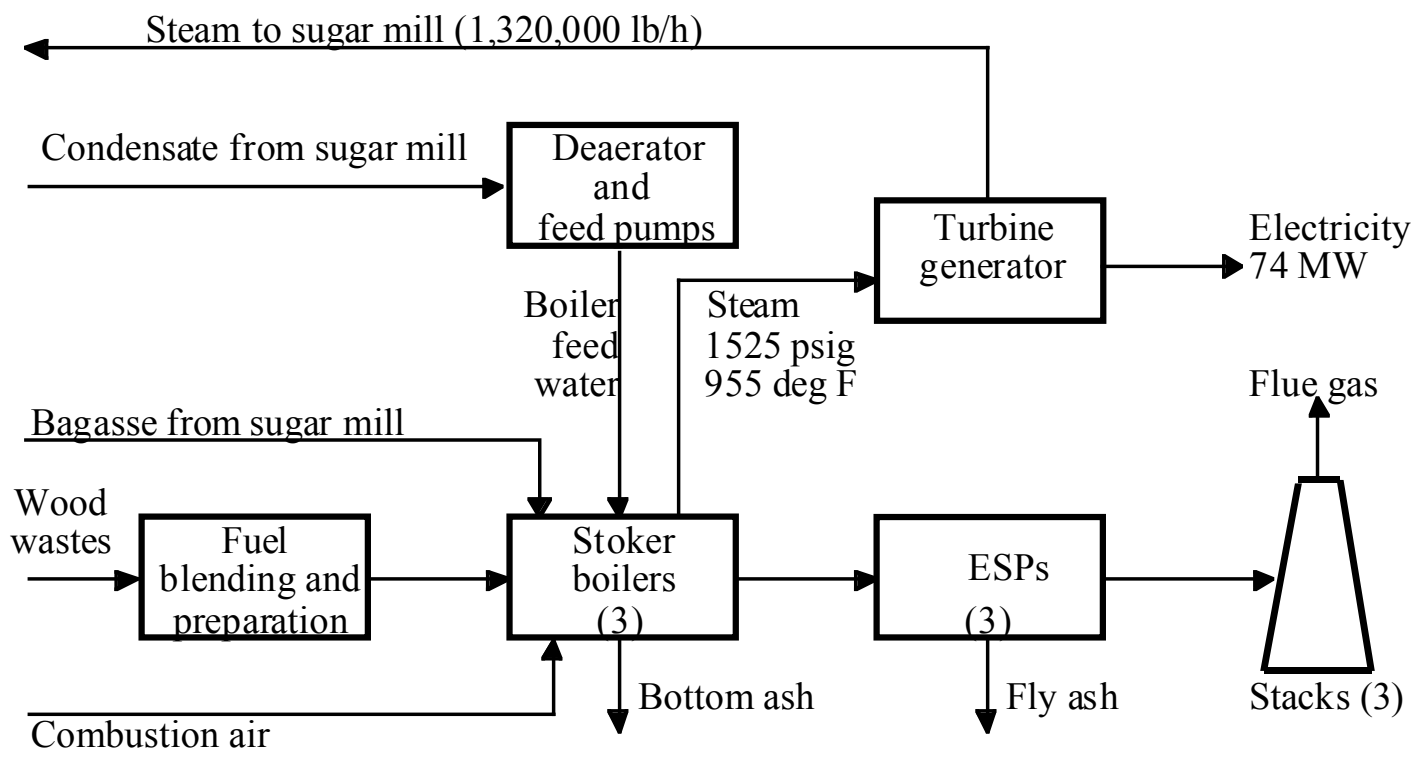

Construction in the Everglades

South Florida's Everglades are noted as an endless swampland of muck, posing a serious problem for any structure needing a stable base. The water table sometimes rises to within inches of the surface. To stabilize the area, Bechtel excavated 6 acres of muck and replaced it with $300,000 \mathrm{t}$ of crushed limestone at the Okeelanta plant. 
Fuel System

The sugar mill is $200 \mathrm{yd}$ from the cogeneration plant. The support frame for the conveyor that sends bagasse to the cogeneration plant also supports the steam and condensate lines-a 36-in. low-pressure steam line, a 14-in. high-pressure steam line, and an 8-in. condensate line. The bagasse and residue from freshly ground sugar cane are sent to the boilers by conveyor belt. The design rate is $2740 \mathrm{t} / \mathrm{d}$. Two 6-ft-wide dragchains - positioned across the entire boiler building - then distribute the material to each boiler via feeders. Because the low density fuel is fibrous, stringy, and abrasive, a vibratory tray feeder was selected over a conventional screw feeder because:

- The screw auger would have to be replaced annually.

- Horsepower to drive the screw feeder is high.

- The operator has to make adjustments to a screw feeder each time he has to switch from bagasse to wood, or vice versa.

- The screw feeder precludes the potential of burning both fuels simultaneously.

The material handling system overfeeds the boilers; the excess fuel is stacked in the yard and reclaimed as needed. Wood waste is received and processed in a typical fuel yard. Like the bagasse, wood waste is also unloaded and stacked by the conveyor.

Boilers

The plant has three ABB Combustion Engineering stoker-fired boilers with staged air and urea injection control $\mathrm{NO}_{\mathrm{x}}$ emissions. Each generator is designed to deliver $440,000 \mathrm{lb} / \mathrm{h}$ of steam at $1525 \mathrm{psig}$ and $955^{\circ} \mathrm{F}$ at the boiler outlet. In addition to burning bagasse and wood chips, the boilers can burn coal as high as $40 \%$ of heat input at maximum continuous rating. The stoker boilers have water-cooled vibrating grates. Strategically located overfire air jets provide turbulence and thoroughly mix the fine fuel particles and air to ensure complete combustion and $\mathrm{NO}_{\mathrm{x}}$ control.

Each furnace provides continuous ash discharge via an advanced design spreader stoker that burns coal, biomass, and other solid waste fuels-specifically, low-Btu, high-moisture waste fuels. The water-cooled ash discharge grates combine water cooling protection of the grate surface with intermittent grate vibration to move the fuel bed forward through the furnace; ash is automatically discharged off the forward end of the grates. Higher combustion air temperatures needed to completely burn out the high moisture fuel can be maintained without concern for damaging the grates. Nine under-grate air plenums optimize air flow distribution to various areas of the furnace.

Biomass enters the furnace through pneumatic fuel distributors located on the furnace's front wall. They disperse the fuel uniformly into the furnace. Fine particles of fuel entering the furnace are burned in suspension. Strategically located high-pressure overfire air jets provide turbulence and thoroughly mix the fine fuel and air to ensure complete combustion and $\mathrm{NO}_{\mathrm{x}}$ control. The coarser, heavier fuel particles are spread evenly on the grate, forming a thin, fast-burning fuel bed. The fuel is rapidly consumed by the combination of suspension and thin fuel bed burning, which makes this method of firing responsive to load demand.

\section{Emissions Control}

To meet the stringent $\mathrm{NO}_{\mathrm{x}}$ emissions requirements of $0.15 \mathrm{lb} / \mathrm{MBtu}$ while firing bagasse, wood waste, or a combination of both, each boiler incorporates a tangential overfire air system with undergrate air and a selective noncatalytic reduction (urea injection) system. 
The overfire air system comprises five elevations of tangential air registers and one elevation of nozzles located above the grate on the rear wall of the unit. A boost fan increases air pressure, thus providing proper penetration of air flow into the furnace and turbulent mixing of overfire air with combustion gases coming up off the grate.

Introduction of overfire air at five elevations reduces $\mathrm{NO}_{\mathrm{x}}$ and $\mathrm{CO}$ production by staging combustion, increasing residence time, and thoroughly mixing the flue gas. When firing at reduced loads, separate elevations of overfire air can be shut off to maintain the velocities required to ensure complete mixing of the flue gas. The selective non-catalytic reduction (SNCR) system trims $\mathrm{NO}_{\mathrm{x}}$ emissions. The urea-based system includes two levels of injection, each of which consists of six injectors located on all four walls to accommodate temperature and mixing profiles in the flue gas.

Three ABB Environmental ESPs, one per boiler, remove PM from the stack gas. Each ESP has three fields in series and is designed for outlet emissions of $0.03 \mathrm{lb} / \mathrm{MBtu}$ when the boiler is firing $100 \%$ bagasse, $100 \%$ wood waste, or a combination of the two fuels. The ESPs' spiral electrodes are hung in a rigid frame with nominal 16-in. collecting plate spacing. This wide plate spacing is an economical design and is particularly well suited to biomass applications.

Because of the relatively high content of carbon in the ash, the risk of fire damage to the ESPs is a common problem with boilers firing biomass. As a result, the ESPs were designed with three specific features to reduce the risk of fire damage:

- Induced draft fans located upstream of the ESPs, to ensure the units operate at positive pressure, reducing the risk of ambient air in-leakage that could support combustion.

- Trough-type hoppers equipped with screw conveyors to remove fly ash continuously.

- High intensity tumbling hammer rappers to keep the collecting plates free of potentially combustible material.

Each ESP has its own 225-ft-high, 10-ft-diameter stack mounted directly over the outlet plenum. Given the upstream ID fan location and that the ESP roof elevation is nearly $90 \mathrm{ft}$ above grade, the ESP-mounted stacks represent significant cost and space savings over a conventional free-standing stack arrangement at grade.

\section{Staffing}

At peak construction, approximately 350 jobs were created. The Okeelanta Cogeneration plant was planned to have 34 full-time employees. Another 80-90 workers process and transport the fuels. 


\section{Fuels}

Each year, about two-thirds of the total fuel requirements are met by bagasse, and the remainder by wood waste. The sugarcane harvesting and grinding season lasts about 6 months, from October through late March or early April. Bagasse cannot be stored for long times without deterioration of its fuel value, so many bagasse-fired cogeneration plants rely on a supplemental fuel such as wood waste or coal during the off-season when bagasse is not being produced as a by-product of the sugar mill. The fuel at the Okeelanta Cogeneration plant is not dried before combustion.

Wood wastes used as fuel at the plant include urban wood wastes, land clearing wood wastes, and some construction debris. One type of wood waste is melaleuca, a pest tree that threatens to overwhelm the everglades. Melaleuca trees, which soak up about 50 gal of water a day, were imported decades ago from Australia to dry out land in the Everglades to make it buildable. The gnarly trees have successfully taken root and smothered native vegetation. They have no native predators. When cut down, they grow back. When burned, their seedlings spread, giving birth to yet more trees. They burn well in the Okeelanta boiler, and the plant now receives as many as 10 truckloads a day from land clearing activities in the Everglades. Since 1990, the South Florida Water Management District has cleared more than 6 million melaleuca trees and 22 million seedlings from Everglades National Park and from water conservation and wildlife management areas. Until the Okeelanta Cogeneration plant started operating, the district had no options other than to haul melaleuca to the landfill or burn it on site.

\section{Operating Experience}

Early operations (late 1996 into summer 1997) at Okeelanta were described by a former employee as "up and down," mostly because the contractor "did not build the plant well." Fuel quality problems were experienced with some wood wastes. It was difficult to find enough good-quality wood wastes in the area.

From February 1998 to February 1999 the Okeelanta plant has run at a steady rate as required to meet the sugar mill's energy demands. The Okeelanta sugar mill and refinery have no off season. They run year round except for scheduled maintenance shutdowns, processing extract from cane and processing sugar. No details on the Okeelanta Cogeneration Plant's steam or electricity production levels during 1998 were made available.

\section{Environmental Performance}

Annual aggregate emissions levels are about $75 \%$ less than previous levels produced by the sugar mill's 50-year-old boilers, even though the new plant produces $74 \mathrm{MW}$ of electricity and meets all steam and power requirements that were previously handled by the mill's boilers. The cogeneration plant's air quality permits link the two facilities. After the cogeneration plant has operated long enough to establish its reliability, the sugar mill will be required to dismantle the old boilers.

The design emission rates for the Okeelanta plant, in pounds per million Btu, are 0.1 for $\mathrm{SO}_{2}, 0.15$ for $\mathrm{NO}_{\mathrm{x}}$, and 0.03 for PM. All environmental monitoring and testing to date indicate that the plant is operating within its permit requirements. However, a brief news item in Waste News, August 11, 1997, stated that ash produced by the Okeelanta and Osceola plants contains elevated levels of arsenic and chromium. 


\section{Economic Information}

The reported total capital cost for the Okeelanta plant was $\$ 194.5$ million; based on 74 MW, this is equivalent to about $\$ 2800 / \mathrm{kW}$ in 1998 dollars. The Osceola plant's total capital cost was reported as $\$ 162$ million; based on $52 \mathrm{MW}$, this is equivalent to about $\$ 3300 / \mathrm{kW}$ in 1998 dollars.

\section{Lessons Learned}

The Okeelanta Cogeneration Plant provides many environmental benefits, and should serve as a reliable energy source for the sugar mill and the electric utility. Unfortunately, the partnership and the utility could not resolve their differences amicably. The lawsuits, bankruptcy, shutdown, and layoffs significantly reduced the project's value to all its stakeholders. Hopefully, the project is now on a track where it can operate steadily.

\section{Sources and Contacts}

Nearly all the information in this section was obtained from a series of magazine and newspaper articles, including Power, August 1995, and ENR, December 12, 1994.

Additional information was obtained in discussions with James Meriweather, environmental manager at the Okeelanta Cogeneration Plant, in February 1999.

James Meriweather

Environmental Manager

Okeelanta Cogeneration Plant

P.O. Box 9

South Bay, FL 33493

Phone: 561-993-1010 


\section{LAHTI GASIFICATION COFIRING PROJECT, LAHTI, FINLAND}

The goal of the Lahden Lampovoima Oy's Kymijarvi power plant gasification project is to demonstrate the direct gasification of wet biofuel and the use of hot, raw and very low-Btu gas directly its coal boiler. Lahden Lampovoima Oy (LLO) operates the Kymijarvi power plant near the city of Lahti in southern Finland. The Kymijarvi power plant is a PC-fired steam plant that generates as much as $167 \mathrm{MW}_{\mathrm{e}}$ of electricity and as much as $240 \mathrm{MW}_{\text {th }}$ of district heat production. Starting in January 1998, a CFB gasifier began operation on a recycled fuel mixture consisting of mostly wood, paper, cardboard, and a small amount of plastic. The gasifier capacity is about $45 \mathrm{MW}_{\text {th }}$, which is about $15 \%$ of the boiler's average heat input. The gasifier has run from January 1998 through January 1999 with an availability of about $98 \%$.

\begin{tabular}{llr}
\hline \multicolumn{3}{l}{ Vital Statistics } \\
\hline Configuration & \multicolumn{2}{l}{ CFB gasifier feeding raw low-Btu } \\
& gas to burners in coal-fired boiler \\
\hline Design capacity & Boiler & 167 MWe \\
& & 240 MWth \\
& Gasifier & 45 MWth \\
\hline Fuels & Coal & 1200 \\
(GWh/yr thermal) & Natural gas & 800 \\
& Biomass & $\sim 300$ \\
\hline
\end{tabular}

\section{History and Outlook}

In Europe, typically about 30-150 MW of biofuel energy is available within $50 \mathrm{~km}$ from the power plant. This amount can be gasified and used directly in mid- or large- sized coal fired boilers. Thus, a power plant concept consisting of a gasifier connected to a large conventional boiler with a high efficiency steam cycle offers an attractive and efficient way to use local biomass sources in energy production.

Foster Wheeler Energia Oy developed the CFB gasification process in the early 1980s. The first commercial gasifier was installed in 1983, and is still operating, replacing fuel oil in a lime kiln at Wisaforest Oy, Jacobstad, Finland. Similar gasification plants having the same basic technology were installed at two pulp mills in Sweden $(1985,1986)$ and one mill in Portugal (1986). These gasifiers convert bark and waste wood to low-Btu gas (17-35 $\mathrm{MW}_{\mathrm{th}}$ ), which is used as fuel in lime kilns and drying plants.

LLO produces power and district heat for the city of Lahti. The company is $50 \%$ owned by the city of Lahti and 50\% owned by Imatran Voima Oy (IVO), which is the largest electric utility company in Finland. The Kymijarvi power plant started up in 1976, and produces electric power for the owners and district heat for Lahti city. The maximum power capacity is $167 \mathrm{MW}_{\mathrm{e}}$ and the maximum district heat production is $240 \mathrm{MW}_{\mathrm{th}}$. Originally the plant was heavy oil fired, but in 1982 was modified for coal firing. In 1986, a gas turbine 
generator set, from which exhaust heat was used for preheating the boiler feed water, was installed at the plant. The maximum electrical output of the gas turbine is $49 \mathrm{MWe}$ when the outside temperature is $-13^{\circ} \mathrm{F}$.

The boiler operates about $7000 \mathrm{~h} / \mathrm{yr}$. During the summer, when the heat demand is low, the boiler is shut down. During the spring and autumn, the boiler is operated at low capacity with natural gas as the main fuel.

Based on evaluations of local biomass and waste resources, the plant owners decided to add a CFB gasifier to the facility and to cofire the low-Btu gas in the boiler, displacing some of the coal used. Funding was provided from the EU Thermie program. The gasifier started up in January 1998; the first switchover to gasification mode took place on January 14. After some initial testing, the gasifier moved into commercial operation and has had an availability factor of about 98\% through January 1999.

\section{CFB Gasification}

The Foster Wheeler Energia Oy atmospheric CFB gasification system is very simple. It consists of a reactor in which the air-blown fluidized gasification takes place, a "uniflow" cyclone to separate the circulating bed material from the gas, and a return pipe for returning the circulating material to the bottom part of the gasifier. All these are entirely refractory lined. Typically, after the uniflow cyclone, hot product gas flows into the air preheater, which is located below the cyclone.

The gasification air, blown with the high-pressure air fan, is fed to the bottom of the reactor via an air distribution grid. When the gasification air enters the gasifier below the solid bed, the gas velocity is high enough to fluidize the particles in the bed. At this stage, the bed expands and all particles are in rapid movement. The gas velocity is so high that many particles are conveyed from the reactor into the cyclone. The fuel is fed into the lower part of the gasifier above the air distribution grid.

The operating temperature in the reactor is typically $1470^{\circ}-1830^{\circ} \mathrm{F}$, depending on the fuel and the application. When entering the reactor, the biofuel particles start to dry rapidly and a first stage of reaction, namely pyrolysis, occurs. During this reaction stage, fuel converts to gases, charcoal, and tars. Part of the charcoal goes to the bottom of the bed and is oxidized to $\mathrm{CO}$ and $\mathrm{CO}_{2}$, generating heat. These products then flow upward in the reactor, and a secondary stage of reactions takes place, which can be divided into heterogeneous reactions, where char is one ingredient in the reactions, and homogeneous reactions, where all the reacting components are in the gas phase. A combustible gas is produced which enters the uniflow cyclone and exhausts from the system together with some of the fine dust.

Most solids in the system are separated in the cyclone and returned to the lower part of the gasification reactor. These solids contain char, which is combusted with the air that is introduced through the grid nozzles to fluidize the bed. This combustion process generates the heat required for the pyrolysis process and subsequent mostly endothermic reactions. The circulating bed material serves as heat carrier and stabilizes the temperatures. 
The heat energy in the gas is in three forms: chemical heat (combustion); sensible heat (hot gas); and carbon dust (combustion). In normal operation, the fuel feed rate will define the capacity of the gasifier and the air feed rate will control the temperature in the gasifier. Coarse ash accumulates in the gasifier and is removed from the bottom of the gasifier with a water-cooled bottom ash screw.

\section{Plant Flowsheet and Design Information}

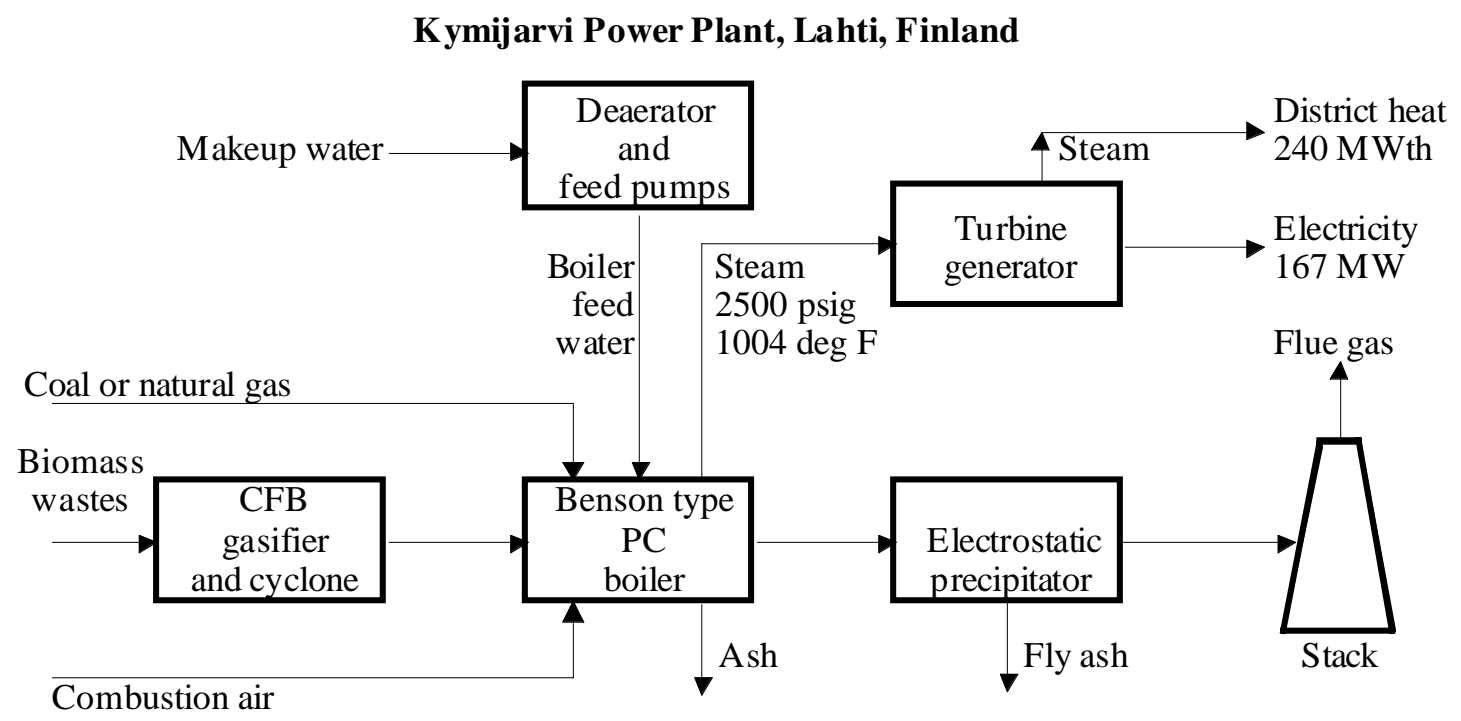

\section{Gasifier}

The Lahti CFB gasifier is a refractory-lined steel vessel and cyclone as described earlier. In the gasifier, biofuels and RDF are converted to combustible gas at atmospheric pressure at a temperature of about $1560^{\circ} \mathrm{F}$. The hot gas flowing through the uniflow cyclone is cooled in the air preheater before it is fed into the main boiler. The gasification air is heated in the air preheater before it is fed to the gasifier.

The major difference from the gasifiers Foster Wheeler supplied in the mid-1980s is that fuel is not dried in this application, and the moisture content of the fuel can be up to $60 \%$. No considerable changes have been made to the design of the gasifier, air preheater, or gas line. Some mechanical changes compared to the standard atmospheric biomass gasifiers were made to accommodate the special nature of the fuel components to be used in the gasifier. For fuels such as RDF, some wood wastes, and shredded tires, which may contain different types of solid impurities (nails, screws, metal wires, concrete), the air distribution grid and the bottom ash extraction system were modified.

\section{Boiler}

The Benson once-through boiler generates $992,000 \mathrm{lb} / \mathrm{h}$ of steam at $2500 \mathrm{psig}$ and $1004^{\circ} \mathrm{F}$, and at 588 psig and $1004^{\circ} \mathrm{F}$. The boiler is not equipped with a sulfur removal system. However, the coal contains only 0.3 to $0.5 \%$ sulfur. The burners are provided with flue gas circulation and staged combustion to reduce $\mathrm{NO}_{\mathrm{x}}$ emissions. 
The low-Btu gas from the gasifier is led directly from the cyclone through the air preheater to two burners located below the coal burners in the boiler. The gas is burned in the main boiler where it replaces part of the coal consumption. When the fuel is wet, the heating value of the gas is very low. Typically, when the fuel moisture is about $50 \%$ the heat value of the gas is only about $59 \mathrm{Btu} / \mathrm{scf}$. The design of the low-Btu gas burners is unique and is based on pilot-scale combustion tests and CFD modeling work.

Fuel System

Fuel preparation systems grind and screen the biomass and waste fuels and remove tramp metal. The sized fuel is conveyed to a feed bin, and from there is metered into the gasifier. An exceptional level of effort was invested in getting the feedstock handling system to operate efficiently and reliably. All the biomass is received onsite in trucks, either selfunloading for sawdust or tipping for some of the RDF fuels. The REF fuel arrives in an unloading hall. Although all feed suppliers have signed contracts to ensure that there are few or no noncombustible or hazardous materials (e.g., treated wood, plastics), the hall is under continuous video surveillance for verification. Noncomplying truckers or suppliers are quickly removed from the list of approved vendors.

After tipping and inspection the material goes into a slowly rotating crusher, which also handles the oversized biomass materials. There is a second receiving station for peat, sawdust, and chipped wood. The self-unloading trucks discharge in a heated and controlled ventilation hall (meeting two objectives: winter unloading and fugitive dust elimination), onto a screen to separate oversized materials, which go to the RDF crusher. Underground conveyors take the material under magnetic separators and over a disk screen before discharge in a large covered A-frame storage facility.

This storage silo is the key to the smooth operation of the facility. The biomass is discharged onto the top of a linear pile ( $150 \mathrm{~m}$ long) and the discharge is arranged so a thin layer of the current load is deposited on the top of the pile and along its length as this layer is swept backward and forward along the length of the pile. Mixing is effected by the use of a horizontal screw that travels transversely along the base of the pile. This screw discharges onto the feed conveyor to the gasifier. It is an effective mixing device, since in cross section the pile looks like a triangular layer cake.

There is only a small amount of surge capacity in the gasifier building. The feed flows through two sets of rotary valves that isolate the gasifier at slightly above atmospheric pressure. Nuclear gauges are used to measure silo and bin levels. The gasifier's air grid has been modified to ensure that the larger contaminants from the RDF fuel can be withdrawn from the bottom of the unit. Tire fuels have proved to be difficult in this respect because of the wires in radial tires causing blockages in the sand withdrawal screw.

Emissions Control

An ESP moves fly ash from the boiler flue gas. 


\section{Fuels}

The boiler uses about 200,000 t/yr of coal and about 2.73 billion scf/yr of natural gas. These are equivalent to thermal energy inputs of $1200 \mathrm{GWh} / \mathrm{yr}$ of coal and $800 \mathrm{GWh} / \mathrm{yr}$ of natural gas, or about $60 \%$ coal and $40 \%$ gas. The coal has a low sulfur content, about $0.3 \%-0.5 \%$. About $1.0 \times 10^{12} \mathrm{Btu} / \mathrm{yr}(300 \mathrm{GWh} / \mathrm{yr})$ of various types of biofuels and refuse fuels are available in the Lahti area, as follows:

$\underline{\text { Fuel }}$

Sawdust

Wood residues (bark, wood chips, etc.)

Dry wood wastes from the wood working industry (plywood, particle board, etc.)

Recycled fuel (RF)

\begin{tabular}{cc} 
Weight \% of Total & Weight \% Moisture \\
\cline { 2 - 2 } 30 & $45-55$ \\
30 & $45-55$ \\
30 & $10-20$ \\
& $10-30$
\end{tabular}

The RF is produced from refuse of various origins, which comes from households, offices, shops, and construction sites in the area. Waste is separated at the source in Finland, so the REF contains primarily clean paper and plastic. The processing of REF was started by the municipally owned waste management company Paijat-Hameen Jatehuolto Oy in 1997. The REF fuel composition is estimated as follows:

\begin{tabular}{|c|c|}
\hline Component & Weight \% \\
\hline Plastics & $5-15$ \\
\hline Paper & $20-40$ \\
\hline Cardboard & $10-30$ \\
\hline Wood & $30-60$ \\
\hline
\end{tabular}

The amount of biofuels and refuse fuels available each year is enough to substitute for about $15 \%$ of the fuels burned in the Lahti plant's boiler, or to substitute for $30 \%$ of the coal burned. Assuming $7000 \mathrm{~h} / \mathrm{yr}$ of plant operation, $300 \mathrm{GWh} / \mathrm{yr}$ is equivalent to about 43 MW of thermal energy available from local biofuels. In addition to the REF fuel components, peat, demolition wood waste, and shredded tires are used as fuels in the gasification plant.

\section{Operating Experience}

During the first week of operation in January 1998, the gasifier startup and shutdown cycles were tested, and the stabilities of the boiler and gasifier were monitored in various cases. These tests were successful. The gasifier has been in continuous operation since January 21, 1998 (except during periods of low energy demand in the summer, when the boiler does not run). The operation of the gasifier as well as the operation of the gas burners has been stable despite the low heating value of the gas. The measured gas quality has matched well with the design calculations. The load of the gasifier has been varied between 30 and $45 \mathrm{MW}_{\text {th }}$ and most of the time the gasifier has been run at full load.

The first operating period of the gasifier took place from January 9, 1998, to June 2, 1998. The gasifier was connected to the main boiler on December 7, 1997 and after warming up the refractory lining the first combustion tests with solid fuel (biomass) were performed on January 9, 1998. The first gasification tests were carried out on January 14, 1998 and the unit has been in continuous operation since week 4, 1998. During the first heating season approximately $2700 \mathrm{~h}$ of operation were achieved. 
The experience during initial operations was successful, with very few problems and high plant availability. Temperatures, pressures, flow rates, and gas composition were very close to design values. The stability of the boiler steam cycle has been good. The large openings that were made for the low-Btu gas burners caused no disturbances in the water circulation. The operation of the burners has been good. Combustion of the low-Btu gas has been stable despite the high moisture content of the fuel (45\%-58\%) and the very low heating value of the gas.

Because of shortages of fuel and problems in the fuel preparation plant at times, the gasifier was occasionally operated in the combustion mode during the first operating season. This keeps the fuel consumption at a low level while maintaining normal temperatures in the gasifier. The capacity of the gasifier in the combustion mode has typically been 5-7 $\mathrm{MW}_{\mathrm{th}}$.

The gasifier and the boiler performance have been extensively monitored. No fouling or corrosion has been found on probes placed in the boiler. The gas produced has about 6-8 $\mathrm{g} / \mathrm{Nm}^{3}$ dust and tar contents on a wet gas basis. There is less than $0.1 \mathrm{ppv}$ of alkali. Fuelbound nitrogen contributed about $1 \mathrm{~g} / \mathrm{Nm}^{3}$ of $\mathrm{NH}_{3}$ and $25-45 \mathrm{mg} / \mathrm{Nm}^{3} \mathrm{HCN}$ on a dry gas basis. At the boiler there has been a reduction of $10 \mathrm{mg} / \mathrm{MJ}$ in $\mathrm{NO}_{\mathrm{x}}$ production, and similar reductions in dust loading. The coals used are essentially chloride free. Tests for dioxins, furans, and chlorinated phenols/benzenes and PAH in both the boiler flue gas and the ash streams demonstrated very low values.

\section{Environmental Performance}

The gasification of biofuels and cocombustion of gases in the coal-fired boiler offers many advantages, such as recycling of $\mathrm{CO}_{2}$, decreased $\mathrm{SO}_{2}$ and $\mathrm{NO}_{\mathrm{x}}$ emissions, and an efficient way to use biofuels and recycled REF. Measurements indicated the following changes in emission levels when the boiler was cofiring biomass-derived gas:

$\begin{array}{ll}\mathrm{NO}_{x} & \text { Decrease by } 10 \mathrm{mg} / \mathrm{MJ}(5 \text { to } 10 \%) \\ \mathrm{SO}_{2} & \text { Decrease by } 20-25 \mathrm{mg} / \mathrm{MJ} \\ \mathrm{HCl} & \text { Increase by } 5 \mathrm{mg} / \mathrm{MJ} \\ \mathrm{CO} & \text { No change } \\ \text { Particulates } & \text { Decrease by } 15 \mathrm{mg} / \mathrm{Nm}^{3} \\ \text { Heavy metals } & \text { Slight increase in some elements, base level low } \\ \begin{array}{l}\text { Dioxins, furans, PAH, } \\ \text { benzenes, phenols }\end{array} & \text { No change }\end{array}$

\section{Economic Information}

Specific information on the capital investment in the gasification/cofiring system at Lahti is not available. As a general case, that the capital cost of such a system is estimated at \$400$650 / \mathrm{kW}$. Only small modifications are required to the boiler, and possible disturbances in the gasifier do not shut down the power plant. 


\section{Lessons Learned}

No significant problems have been reported during the 1 year that the Lahti biomass gasifier has been operating. Technically, the operation is successful so far. This unit is the fifth CFB biomass gasifier Foster Wheeler has installed in European plants since 1983, and all have been reliable, according to Foster Wheeler. This technology gives utilities in the United States another option to consider when examining the feasibility of cofiring biomass and waste fuels in coal-fired boilers.

\section{Sources and Contacts}

Nearly all the information in this section is from the following three documents:

- An article in the February 1998 issue of Modern Power Systems, entitled "Thermie demonstrates biomass CFB gasifier at Lahti." The authors were Juha Palonen and Jorma Nieminen of Foster Wheeler Energia Oy and Eero Berg of Foster Wheeler Service Oy, Varkaus, Finland.

- A foreign travel trip report by Ralph Overend of NREL, following his attendance at the Seminar on Power Production from Biomass III; Gasification and Pyrolysis RD\&D for Industry, Espoo, Finland, September 14-15, 1998. A tour of the Lahti gasification plant was included.

- A technical paper from August or September 1998 by Juha Palonen and Jorma Nieminen of Foster Wheeler Energia Oy, entitled "Biomass CFB Gasifier Connected to a $350 \mathrm{MW}_{\text {th }}$ Steam Boiler Fired with Coal and Natural Gas -Thermie Demonstration Project in Lahti in Finland."

Additional information was obtained from a presentation (no written paper) by Neil Raskin of Foster Wheeler Development Corporation at the BIOENERGY '98 Conference, October 4-8, 1998, and from discussions with David Tillman of Foster Wheeler Development Corporation in January 1999. No direct contact has been made with personnel at the Kymijarvi power plant in Lahti. Contacts at Foster Wheeler in the United States are:

Neil R. Raskin

Director, Global New Products

or

David A. Tillman, Ph.D.

Project Manager, Global New Products

Foster Wheeler Development Corporation

Perryville Corporate Park

Clinton, NJ 08809-4000

Telephone: Raskin 908-713-3190

Tillman: 908-713-3181

Fax: 908-713-3195 


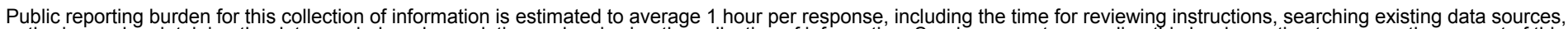

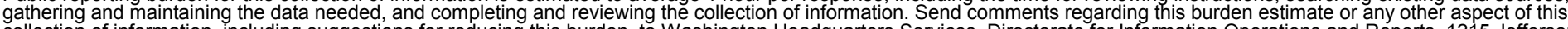

Headquarters Services, Directorate for Information

Davis Highway, Suite 1204, Arlington, VA 22202-4302, and to the Office of Management and Budget, Paperwork Reduction Project (0704-0188), Washington, DC 20503.

\begin{tabular}{|l|l|l|l|} 
1. AGENCY USE ONLY (Leave blank) & $\begin{array}{c}\text { 2. REPORT DATE } \\
\text { January } 2000\end{array}$ & $\begin{array}{l}\text { 3. REPORT TYPE AND DATES COVERED } \\
\text { Subcontract Report }\end{array}$ \\
\hline
\end{tabular}

\section{TITLE AND SUBTITLE}

5. FUNDING NUMBERS

Lessons Learned from Existing Biomass Power Plants

C: AXE-8-18008

TA: BP911010

\section{AUTHOR(S)}

G. Wiltsee

\section{PERFORMING ORGANIZATION NAME(S) AND ADDRESS(ES)}

Appel Consultants, Inc.

8. PERFORMING ORGANIZATION

23904 Plaza Gavilan

Valencia, CA 91355

805.253.3492

9. SPONSORING/MONITORING AGENCY NAME(S) AND ADDRESS(ES)

National Renewable Energy Laboratory

1617 Cole Boulevard

Golden, CO 80401-3393

\section{SUPPLEMENTARY NOTES}

NREL Technical Monitor: Richard Bain

\section{2a. DISTRIBUTION/AVAILABILITY STATEMENT}

12b. DISTRIBUTION CODE

National Technical Information Service

U.S. Department of Commerce

5285 Port Royal Road

Springfield, VA 22161

13. ABSTRACT (Maximum 200 words) This report includes summary information on 20 biomass power plants, which represent some of the leaders in the industry. In each category an effort is made to identify plants that illustrate particular points. The project experiences described capture some important lessons learned that lead in the direction of an improved biomass power industry.

\section{SUBJECT TERMS}

biomass, power plant, electricity

15. NUMBER OF PAGES

16. PRICE CODE

18. SECURITY CLASSIFICATION OF THIS PAGE unclassified

\section{SECURITY CLASSIFICATION} OF ABSTRACT unclassified
20. LIMITATION OF ABSTRACT

UL 


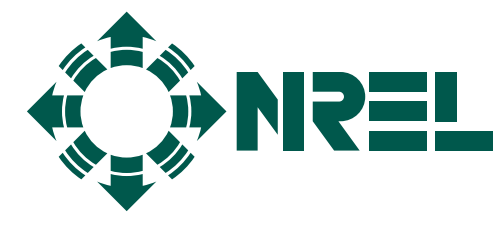

National Renewable Energy Laboratory

1617 Cole Boulevard

Golden, Colorado 80401-3393

NREL is a U.S. Department of Energy Laboratory

Operated by Midwest Research Institute $\bullet$ Battelle $\bullet$ Bechtel

Contract No. DE-AC36-99-G010337

NREL/SR-570-26946

January 2000 